Florae costaricensis subtribui Pleurothallidinis (Orchidaceae) prodromus II. Systematics of the Pleurothallis cardiothallis and P. phyllocardia Groups, and Other Related Groups of Pleurothallis with Large Vegetative Habit

Authors: Pupulin, Franco, Aguilar, Jaime, Belfort-Oconitrillo, Noelia, Díaz-Morales, Melissa, and Bogarín, Diego

Source: Harvard Papers in Botany, 26(1) : 203-295

Published By: Harvard University Herbaria

URL: https://doi.org/10.3100/hpib.v26iss1.2021.n14

BioOne Complete (complete.BioOne.org) is a full-text database of 200 subscribed and open-access titles in the biological, ecological, and environmental sciences published by nonprofit societies, associations, museums, institutions, and presses.

Your use of this PDF, the BioOne Complete website, and all posted and associated content indicates your acceptance of BioOne's Terms of Use, available at www.bioone.org/terms-of-use.

Usage of BioOne Complete content is strictly limited to personal, educational, and non - commercial use. Commercial inquiries or rights and permissions requests should be directed to the individual publisher as copyright holder.

BioOne sees sustainable scholarly publishing as an inherently collaborative enterprise connecting authors, nonprofit publishers, academic institutions, research libraries, and research funders in the common goal of maximizing access to critical research. 


\title{
FLORAE COSTARICENSIS SUBTRIBUI PLEUROTHALLIDINIS (ORCHIDACEAE) PRODROMUS II. SYSTEMATICS OF THE PLEUROTHALLIS CARDIOTHALLIS AND P. PHYLLOCARDIA GROUPS, AND OTHER RELATED GROUPS OF PLEUROTHALLIS WITH LARGE VEGETATIVE HABIT
}

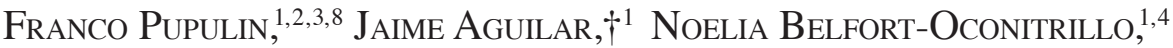 \\ Melissa Díaz-Morales, ${ }^{1,5}$ and Diego Bogarín ${ }^{1,6,7}$
}

\begin{abstract}
We discuss a group of Pleurothallis species mostly characterized by plants relatively tall for the genus, with stems more than $20 \mathrm{~cm}$ long and fasciculate inflorescences produced above the leaf from a spathaceous, sometimes erect bract. We recognize 26 species and 4 natural hybrids in Costa Rica in this group of Pleurothallis, belonging to 4 informal assemblages of species, each one characterized by a unique set of vegetative, floral, and ecological features. This group, as well as its component units, is discussed as to its salient characteristics and internal relationships, underlying possible evolutionary trends. Diversity, general and floral ecology, color dimorphism, and natural hybridization are examined to address their systematic significance. We present a dichotomic key to the groups and the species discussed in this study, together with descriptions based on Costa Rican materials, and one or more line drawings or a Lankester Composite Dissection Plate when required for improved clarity. Also, we discuss their taxonomy and provide information on etymology, habitat, distribution, distinguishing features, and Costa Rican collections. Three species ( $P$. callosa, P. longipetala, and P. mesopotamica), and three nothospecies ( $P . \times$ karremansiana, $P . \times$ subversa, and $P$. $\times$ parentis-certa) are described as new to science, discussed as to their affinities, and illustrated with photographs, composite digital plates, and ink drawings. Pleurothallis triangulabia is removed from the synonymy of P. phyllocardia, treated as a distinct species, and lectotypified. Pleurothallis anthurioides and P. maduroi are first recorded and documented for the flora of Costa Rica.
\end{abstract}

Keywords: flora of Costa Rica, floral activity, lectotypification, natural hybridization, new species, new nothospecies, orchid diversity, Pleurothallidinae

In a previous publication we presented a general overview of the work in progress aimed at completion of the Orchidaceae treatment for Flora Costaricensis, as well as the rationale behind the series of precursors to this floristic treatise, in particular relative to large and taxonomically complex groups of species in the Pleurothallidinae (Pupulin et al., 2020).

Orchid diversity in the subtribe Pleurothallidinae is far from being thoroughly understood. The recent work by Carl Luer and collaborators, aimed at producing a formal treatment of Stelis sensu stricto in Ecuador (Luer, 2002, 2004, 2007, 2009) well exemplify how much our appreciation of a genus's diversity can vary in a short lapse of time. While the monograph of Stelis by Óscar Duque Hernández was waiting to be published, figuring out a total of 363 recognized species in the genus (Duque Hernández 2008), a first century of new species from Ecuador was published by Luer (2002). In the next 7 years, Luer went to press with three more centuries of new Stelis species from Ecuador (Luer 2004, 2007, 2009). In his catalog of the Orchidaceae of Ecuador, Dodson (2004) recorded 448 species of Stelis. Today the genus exceeds, in Ecuador alone, 850 species. This means that a great collection effort focused on a particular group, access to a large amount of material for study, and a better understanding of species circumscriptions and their relationships produced an increase of almost $100 \%$ in the known diversity in a single large genus of Pleurothallids, in a single country, in just 5 years. According to Duque Hernández (2008), this significant number of new species of Stelis "will require a new systematics of the genus." And this does not take into account, of course, the broadening of the generic circumscription of Stelis, as proposed by Pridgeon and Chase (2001) and now broadly accepted (see in particular the general overview of the genus proposed

We thank the Sistema Nacional de Áreas de Conservación (SINAC) for issuing the scientific collection permits for this study. The staff and curators at AMES, CR, JBL, K, SEL, USJ and W for their assistance with herbarium specimens and data. To our colleagues at the research department of Lankester Botanical Garden for helping with fieldwork and documentation of the specimens. The González family and Stephen Kirby for co-funding the Bosque de Paz Orchid Conservation Project, whereby three of the taxa included in this treatment were found. To Willberth Calderón and Alicia Jiménez from Finca Integral Fractal for providing kind permission to collect specimens from their protected land. Daniel Jiménez, Eberhard Kaes, and Gerson Villalobos for helping with information and photographs of specimens. This paper would not have represented the diversity of this orchid group without the precise and pleasing illustrations by Lizbeth Oses, Sara Díaz Poltronieri, Joan M. Ramírez, and Darha Solano Ulate, some of the best illustrators in our research group. We sincerely acknowledge them here for their excellent work. This study is part of Project 814-B0-052, "Flora Costaricensis: taxonomía y filogenia de la subtribu Pleurothallidinae, Orchidaceae," supported by the University of Costa Rica.

${ }^{1}$ Lankester Botanical Garden, University of Costa Rica, P.O. Box 302-7050 Cartago, Costa Rica.

${ }^{2}$ Harvard University Herbaria, Cambridge, Massachusetts, U.S.A.

${ }^{3}$ The Marie Selby Botanical Gardens, Sarasota, Florida, U.S.A.

${ }^{4}$ Orchid Conservation Project, Bosque de Paz Biological Reserve, Bajos del Toro, Valverde Vega, Alajuela, Costa Rica.

${ }^{5}$ Department of Evolutionary Neuroethology, Max Planck Institute for Chemical Ecology, Jena, Germany.

${ }^{6}$ Herbario UCH, Universidad Autónoma de Chiriquí, David, Panamá.

${ }^{7}$ Naturalis Biodiversity Center, Endless Forms group, P.O. Box 9517, 2300 RA Leiden, The Netherlands.

${ }^{8}$ Corresponding author: franco.pupulin@ucr.ac.cr

Harvard Papers in Botany, Vol. 26, No. 1, 2021, pp. 203-295.

(C) President and Fellows of Harvard College, 2021

ISSN: 1938-2944, DOI: 10.3100/hpib.v26iss1.2021.n14, Published online: 30 June 2021 
by Karremans, 2019), which would require the inclusion of hundreds of other species in the "new systematics of the genus."

This argument is also true for groups that have received considerable attention relative to their phylogenetic placement within the subtribe, like Pleurothallis R. Br., but that have been less studied as to their diversity through broad comparative analysis. This paper deals with one such largely neglected group, the species of Pleurothallis R. Br. related to Humboltia cordata Ruiz \& Pavón (1798) (= Pleurothallis cordata [Ruiz \& Pav.] Lindl.), which represents one of the largest assemblages of phylogenetically related taxa within the genus (Luer, 2005). The importance of a valid modern taxonomic treatment of Pleurothallis, in which all taxa are carefully illustrated, transcends the limits of systematic botany, as has been recently shown by Mo and CetzalIx (2015). They recorded the use of Pleurothallis species as remedies in traditional q'eqchi (quekchí) medicine in Guatemala, reporting the difficulty younger members of the q'eqchi communities had in distinguishing Pleurothallis cardiothallis from other morphologically similar species that did not have the same pharmaceutical properties.

In reconstructions of the evolutionary history of the Pleurothallidinae (Pridgeon and Chase, 2001; Pridgeon et al., 2001), this assemblage was shown to be closely related to the group of species that includes the type of Pleurothallis, P. ruscifolia (Jacq.) R. Br., within a clade that also includes Stelis Sw. Pleurothallis sensu stricto is nested within a clade that includes Specklinia Lindl., sister to the clade of Masdevallia/Dracula and related genera. The affinities among the species of the group of $P$. cordata were first recognized by John Lindley (1859), who created Pleurothallis sect. Macrophyllae-Fasciculatae to gather those species within the genus provided with terete-angulate stems, cordate leaves, and fasciculate flowers. The section was typified by Luer (1988) with P. grandiflora Lindl., an Andean species ranging from Venezuela to Bolivia. Several attempts have been made by contemporary authors to nomenclaturally recognize this large assemblage of species, raising generic concepts to accommodate them, but none has gained consensus (Pridgeon, 2005; Karremans, 2016). Pleurothallis section Macrophyllae-Fasciculatae has been treated at the generic rank by Szlachetko and Margońska (2001), who created Zosterophyllanthos. More recently, Luer (2005) reconsidered the validity of the monotypic Acronia C. Presl (1827), broadening the original circumscription of the genus to embrace not only those species with flowers produced in racemes, for example, $A$. phalangifera $\mathrm{C}$. Presl (typus generis) and the taxa assigned by Lindley (1859) to section Macrophyllae-Racemosae, but also the species provided with fasciculate inflorescences, previously assigned to section Macrophyllae-Fasciculatae (Lindley, 1859). According to Luer's circumscription, the group today includes some 170 species of Pleurothallis, not all formally recombined in Acronia. Neither the treatment by Szlachetko and Margońska (2001) nor that by Luer (2005) received substantial recognition in botanical works.
Molecular analyses showed that Pleurothallis is sister to Stelis sensu lato and consecutive sister to Pabstiella Brieger \& Senghas (Pridgeon et al., 2001; Pérez-Escobar et al., 2017). Within this clade, the sampled species with fasciculate inflorescences (i.e., $P$. cardiantha Rchb.f., $P$. cardiothallis Rchb.f., $P$. teaguei Luer, and $P$. truncata Lindl.) are not strictly related to species of Macrophyllae-Racemosae (e.g., P. allenii L.O. Williams and P. rowleei Ames), which would make the use of Acronia sensu Luer (2005) incorrect. Phylogenetic analyses by Pridgeon and Chase (2001) suggested that species of Pleurothallis with fasciculate versus racemose inflorescences clustered on different clades within the genus. Further expanded phylogenetic analyses (Wilson et al., 2011; Pérez-Escobar et al., 2017) based on nuclear $n r I T S$ and plastid matK datasets, including some of the species treated here ( $P$. adventurae, $P$. cardiothallis, $P$. fantastica, $P$. ×silvae-pacis, and $P$. tonduzii), showed relationships similar to those found by Pridgeon and Chase (2001). However, these relationships within Pleurothallis are uncertain because phylogenies based on traditional Sanger sequencing datasets still yield poor resolution and low statistical support for the inference of infrageneric relationships in the Pleurothallidinae. This is mainly because of the limited number of informative characters in the loci analyzed that could be linked to the recent and rapid diversification of the genus (inferred to have occurred around $5 \mathrm{Ma}$ ) (Pérez-Escobar et al., 2017). Moreover, biological phenomena such as the high degree of natural hybridization (notably documented herein) and potential introgression can lead to poorly resolved phylogenies, lack of statistical support, and discordant inferences between nuclear and plastid datasets. These issues can be addressed by multi-locus approaches involving the three different plant genomes, as demonstrated in Pleurothallidinae for a clade of Lepanthes (Bogarín et al., 2018). Therefore, the relationships of the Pleurothallis species treated here remain uncertain as a result of limited available molecular information (including our unpublished Sanger sequences of species of the $P$. cardiothallis and $P$. phyllocardia groups). Also, for the same reason, a phylogenetic-based infrageneric classification of Pleurothallis is not yet possible to propose; thus we prefer to treat these species in four informal assemblages on the basis of morphological similarities rather than on unresolved phylogenies.

This study therefore deals with the taxonomy of the species of Pleurothallis with fasciculate inflorescences produced above the leaf from a spathaceous bract (largely corresponding to $P$. section Macrophyllae-Fasciculatae Lindl., or Zosterophyllanthos Szlach. \& Margońska but excludes the group that Wilson, Belle, et al. (2013) and Wilson, Pupulin, et al. (2013) characterized as the "Mesoamerican clade" of Pleurothallis, made up of fairly small plants and mostly nonresupinate flowers, with a deeply concave lip without a basal glenion (Pupulin et al., in prep.). So circumscribed, the group includes at least 40 taxa in Costa Rica, but this figure has to be considered highly speculative as it also encompasses the taxonomically difficult $P$. discoidea Lindl. complex. These taxa, the so-called 
"frogs," comprise mostly miniature plants with small flowers, and several have complicated taxonomic histories. The complex is likely grossly underestimated as to its real diversity (Pupulin et al., in prep.). The present work focuses therefore on those taxa that are mainly characterized by large vegetative habit, that is, by mature plants with secondary stems (ramicauls) significantly longer than $20 \mathrm{~cm}$. The division is obviously artificial, and some overlapping occurs between small or juvenile individuals of the group treated in the present paper and large individuals of the "frog" group of species. Nevertheless, both in the field and in cultivation, Pleurothallis species with large habits are easily spotted and equally easy to distinguish from the group of species with smaller habit close to P. discoidea Lindl. (Fig. 1). Even when arbitrarily split into large versus small members of the Macrophyllae-Fasciculatae group, the assemblage still embraces several quite different sets of species, each one with unique suites of morphological and ecological characteristics. We discuss these in the Results section of the present paper.

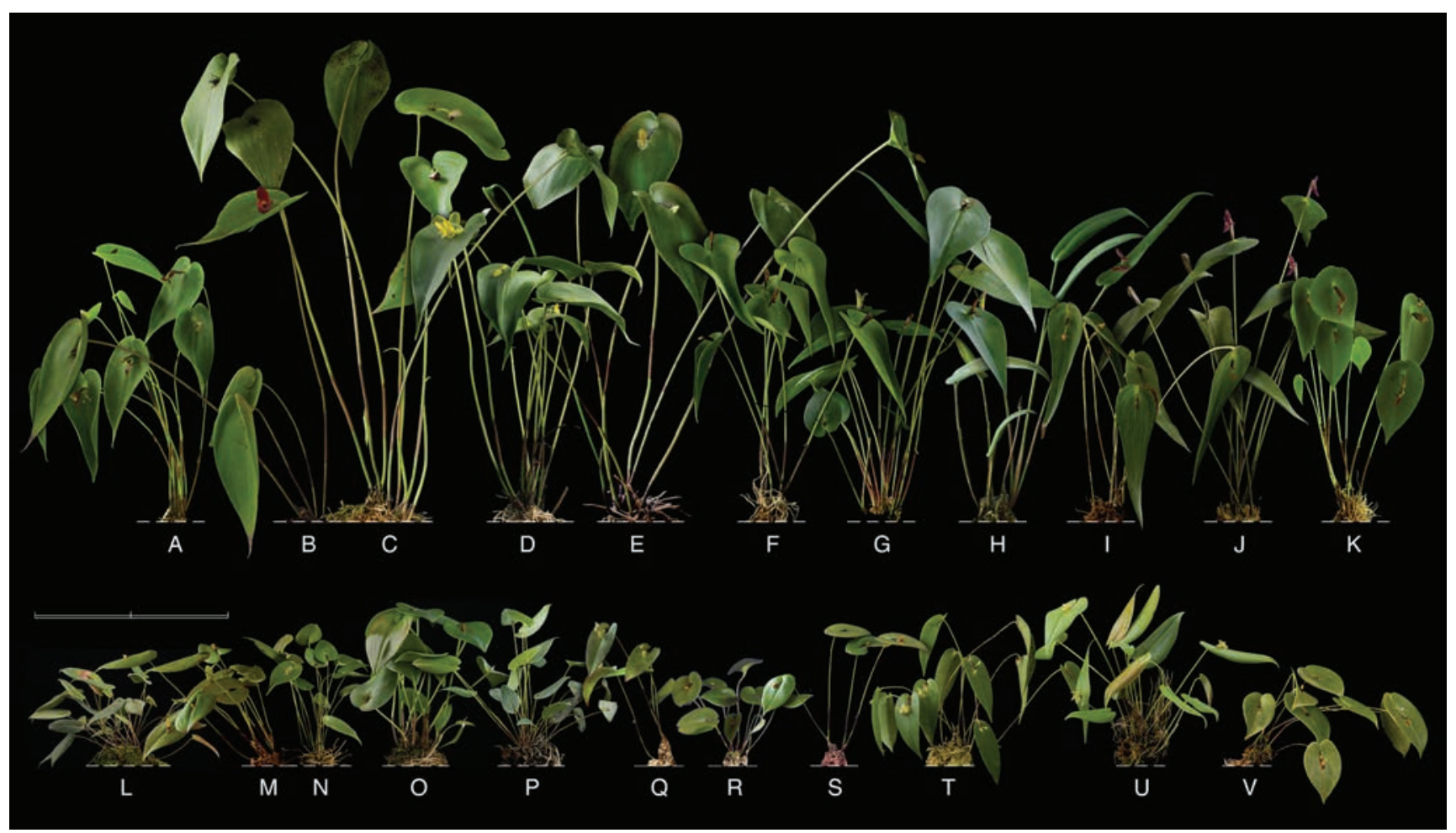

FIGURE 1. A-V. Comparison among Pleurothallis species with large habit treated in this paper (A-K) and other species of Pleurothallis in the Macrophyllae-Fasciculatae group with habit of reduced size (L-V). A, P. phyllocardia (JBL-01967); B, P. scotinantha (Bogarín 7455); C, P. oncoglossa (Bogarín 5686); D, P. navisepala (JBL-33356); E, P. cardiothallis (Pupulin 6414); F, P. rectipetala (Bogarín 574); G, P. radula (Pupulin 8129); H, P. angusta (Karremans 6175); I, P. compressa (Bogarín 7839); J, P. luna-crescens (Zúñiga 178); K, P.pudica (Karremans 6249); L, Pleurothallis sp. (Karremans 7805); M, P. cf. rhodoglossa (Bogarín 6628); N, Pleurothallis sp. (Bogarín 9886); O, Pleurothallis bothros (Karremans 7494); P, Pleurothallis sp. (Pupulin 7563); Q, P. correllii (JBL-02482); R, P. cf. phyllocardioides (Serrano 155); S, P. rhodoglossa (Pupulin 5039); T, P. correllii (JBL-00484); U, P. vide-vallis (Calderón 96); V, P. cf. rhodoglossa (Bogarin 7291). Scale bar $=20 \mathrm{~cm}$. All the vouchers at JBL.

\section{Materials AND Methods}

Plants intended for this study were collected between 2001 and 2018 in suitable areas throughout Costa Rica and brought back to Lankester Botanical Garden (JBL, its acronym in Spanish) for cultivation and successive documentation. Whenever possible, type localities and other critical sites from which rare and/or unique species records were previously reported were visited for plant collecting and subsequent study. At least five specimens per morphospecies were collected at any given locality when possible. Field notes were taken during collections, including GPS and political data, elevation, ecological zones, and main types of vegetation. At JBL, plants were mostly cultivated in individual pots but also on hardwood planks when they seemed intolerant of pot culture; field data were recorded on individual labels affixed to the pots and plaques; and relevant information was stored in the general databases of JBL. Each plant belonging to this group that reached flowering in cultivation was documented by a highresolution image of at least the flower with a scale bar and frequently of the whole plant and floral details with relative scales. Photographs were mostly taken with Nikon cameras (D5200, D7100, D810) mounted on Manfrotto tripods, fitted with macro lenses (Micro Nikkor 60mm f/2.8, Micro Nikkor $105 \mathrm{~mm}$ AF f/2.8, Micro Nikkor 105mm AF/ED f/2.8, Sigma 
DG Macro HSM 105mm f/2.8). Floral details were captured with a Micro-Nikkor $60 \mathrm{~mm}$ f.2.8 mounted on a Nikon PB6 bellow or on extension tubes $(12,20,36 \mathrm{~mm})$, and/ or with microscopes (Leica dissecting stereo microscopes MZ9.5 and M60, and Leica macroscope 16APO) fitted with Leica DFC420 digital color microscope cameras. Images were optimized through post-processing with Adobe $^{\circledR}$ Photoshop CS5 and CS6, and comparative plates of flowers and/or relevant floral details were also prepared using the same software. Drawings of flowers and floral details were prepared using dissecting stereo microscopes Leica MZ9.5 and M60, fitted with Leica ApoPlanar lenses and drawing tubes. Whenever possible, Lankester Composite Dissection Plates (LCDP) and ink illustrations were prepared from individuals showing average characteristics for the portrayed species. Line drawings were done mostly with Rotring Rapidograph technical drawing pens with line widths of 0.1 or $0.2 \mathrm{~mm}$ on Fabriano, acid-free, smooth paper of $240 \mathrm{~g} / \mathrm{m}^{2}$. For some ink plates, the line drawing was prepared using an Apple ${ }^{\circledR}$ iPad and Procreate ${ }^{\circledR}$ digital drawing application, the electronic drawing successively printed on Fabriano paper with a HP Color Laser Jet Pro M452nw, and the printed drawing hand-dotted with a Rotring Rapidograph technical drawing pen. One or more vouchers for each specimen were conserved in the liquid collection of JBL.
Individual plants intended for the description of new species were also preserved as dried specimens to be deposited in national herbaria. To assess individual variability in flower morphology and size through time, several plants belonging to most morphospecies were documented in different years/flowerings, including photographs and dissections of successive flowers during the same flowering season, and vouchers in spirit were prepared for any individual flower, associated with the time of flowering. Notes on floral ecology were taken through direct observation of the plants under the semiartificial conditions of open greenhouses. The aging of individual flowers was documented with the same techniques and equipment described above for general flower documentation. Measurements were mostly taken under a dissecting stereoscope or with the aid of electronic scale bars inserted in the high-definition images of floral details. The major herbaria of the country, as well as relevant herbaria that allow digital access to their collections, were utilized to study specimens of the taxa intended for this study, and specimens were annotated when required. Source information on the taxonomy of these taxa, including at least the original protologues, nomenclatural types, type materials, and associated elements, were digitized and stored in the JBL databases, where they are available to the public upon request.

RESULTS

Species of Pleurothallis with fasciculate inflorescence produced from a spathaceous bract at the base of the leaf (exerted from the apex of the stem) and provided with a tall or relatively tall vegetative habit present several sets of diagnosable features - both morphological and ecologicalthat allow them to be put into four artificial groups (Fig. 2). The artificiality of these groups largely depends on the presence of taxa that, in several cases, seem to fill the gaps between groups for one or another of the key features used to characterize them. While the existence of these intermediate forms actually prevents our using of these groups as a formal proposal of classification - which would also be unnecessary-evidence suggests that the taxa included in each group do share some common features that, at least in some cases, could be hypothesized as indicating a shared lineage instead of convergent evolution. It is, perhaps, not fortuitous that most of the species with taller habit and larger flowers also show temporal activity of the perianth that is unknown in Pleurothallis outside the P. cardiothallis group, and it seems reasonable to see a link between the erect orientation of the spathe-which is unique to species in the P. phyllocardia group-and the orientation of the flower facing down toward the leaf, somewhat limiting access of pollinators to the perianth, which is also unique to this group. So, our use of the term "artificial" with respect to the systematic frame presented in this paper should be interpreted not as a simple and convenient way to gather species into an identification key but as a way to preliminarily recognize evolutionary paths and trends within the genus, without the limits of formal recognition.

The first group includes only three species diagnosable on a morphological basis, plus two nothospecies described hereafter that are likely the result of the natural cross of $P$. tonduzii with species of Pleurothallis from other groups in the Macrophyllae-Fasciculatae clade. The species close to $P$. tonduzii are vegetatively different from other taxa with tall habit in the very long and narrow leaves with lateral margins often slighting curling underside to increase rigidity of the leaf. The leaves are distinctly coriaceous, dark green, and shiny on the upper surface. The ramicauls are often tinged with blackish brown toward the apex. These characteristics made the species of the group easy to recognize both in the field and in herbaria. The flowers do not show temporal activity of the perianth and flowering is relatively long-lasting, with individual flowers remaining in full anthesis up to eight days. The flowers of $P$. angusta are rigid and someway shiny, while those of $P$. grandilingua and $P$. tonduzii-as well as those of the hybrids created with the latter species - are membranous and matte. In the three species, the lip of the flower presents a constriction toward the apex, where a small midlobe is inserted; this is less pronounced in P. angusta, but clearly distinguishable in several individuals (Fig. 3). The putative hybrids of $P$. tonduzii also present a distinct terminal lobe of the lip, even if it can be somewhat obscure. The lip of P. angusta is shiny, while those of the other two species are matte and distinctly verrucose. The warts may be quite protruding on the apical lobe of $P$. tonduzii, which could be sometimes described as subechinate. In both $P$. grandilingua and $P$. tonduzii, but to a greater extent in the latter, the lip is complexly folded. In $P$. grandilingua it is slightly conduplicate, with the two longitudinal halves becoming convex and flushing toward the apex, where the lamina presents a constriction and where an apical short lobe, in turn biconvex, is inserted. The lip of $P$. tonduzii is three-dimensionally still more complex, and variable within individual plants (Fig. 4). When extended, 


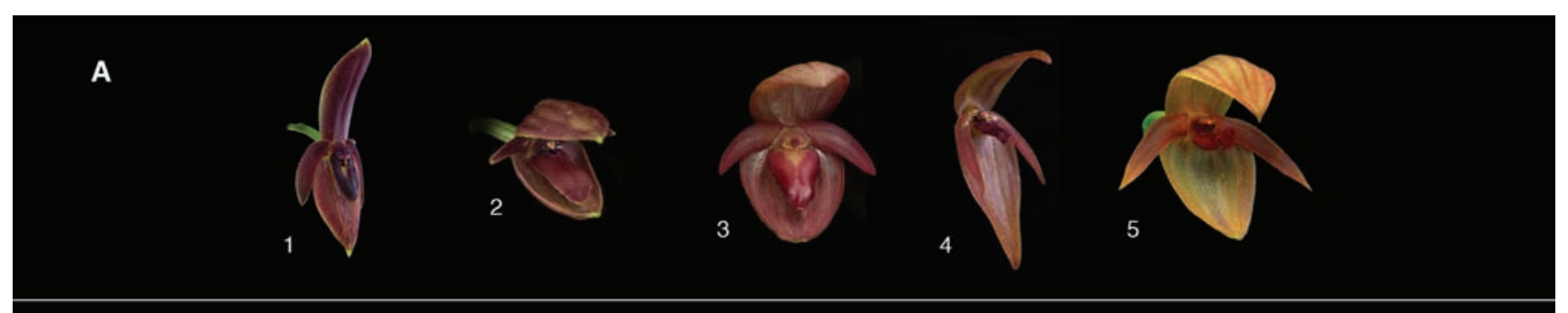

B
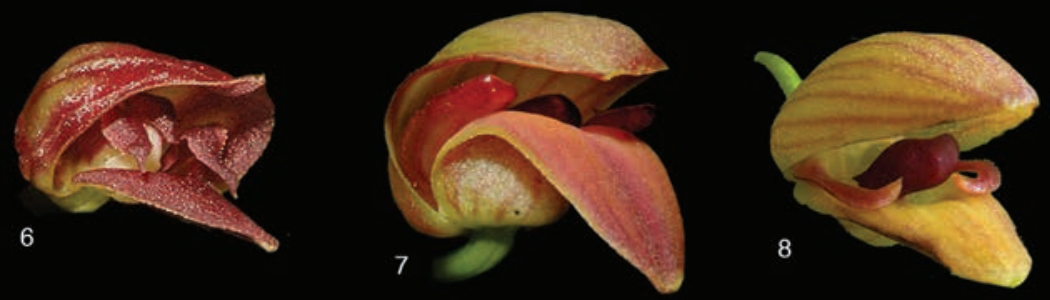

C
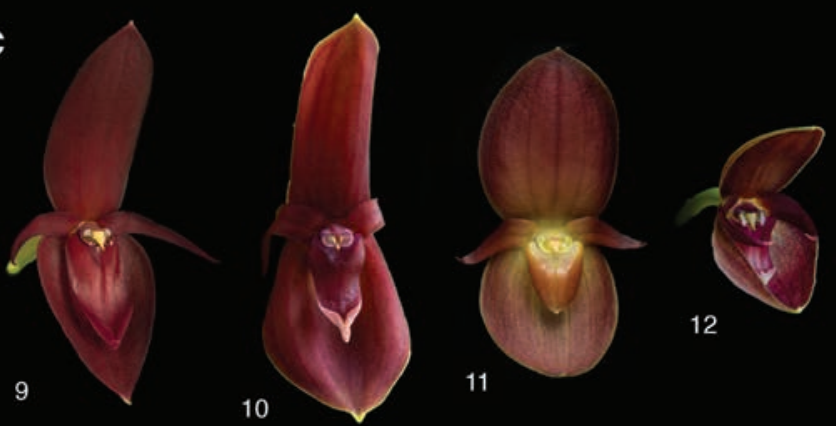

13

14

15

\section{D}
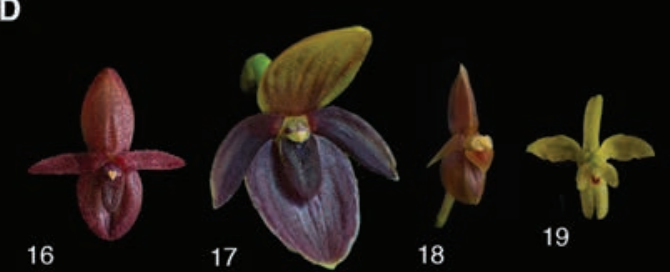

18

19
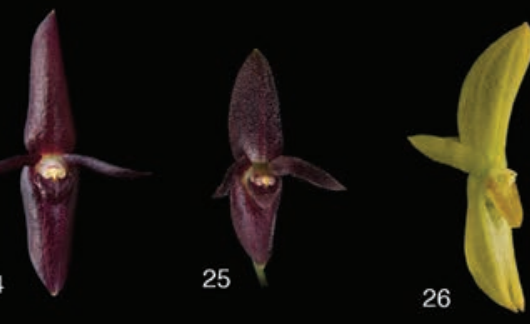

20
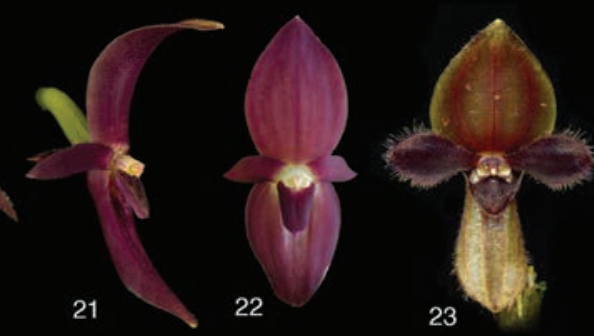

24

26
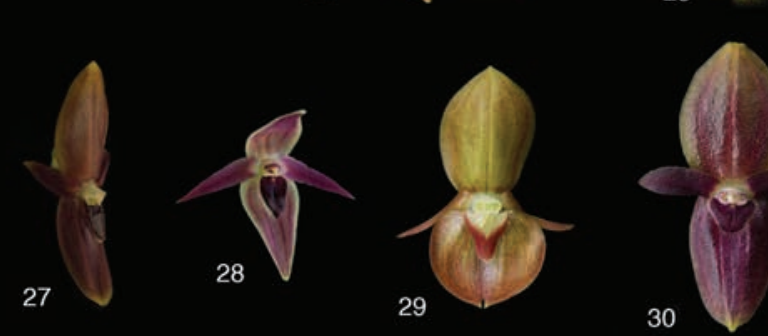

Figure 2. Synopsis of the flowers in different groups and species of Pleurothallis. A, Pleurothallis tonduzii group. 1. P. angusta. 2. P. grandilingua. 3. P. ×karremansiana. 4. P. ×parentis-certa. 5. P. tonduzii; B, Pleurothallis palliolata group. 6. P. chavezii. 7. P. maduroi. 8. P. palliolata; C, Pleurothallis cardiothallis group. 9. P. callosa. 10. P. cardiothallis. 11. P. gonzaleziorum. 12. P. navisepala. 13. P. oncoglossa. 14. P. scotinantha. 15. P. tapantiensis; D, Pleurothallis phyllocardia group. 16. P. adventurae. 17. P. anthurioides. 18. P. compressa. 19. P. fantastica. 20. P. longipetala. 21. P. luna-crescens. 22. P. mesopotamica. 23. P. peculiaris. 24. P. phyllocardia. 25. P. pudica. 26. P. radula. 27. P. rectipetala. 28. P. ×silvae-pacis. 29. P. $\times$ subversa. 30. . triangulabia. Scale bar $=1 \mathrm{~cm}$. All the flowers pictured as resupinate to facilitate comparison, including those that are nonresupinate in natural position $(18,23,25,29)$. Photographs by F. Pupulin, except 6 (R. Joyce), 7 (E. Klaes), 9 (M. Díaz), 20, 26, 30 (D. Bogarín), and 25 (A. P. Karremans). 


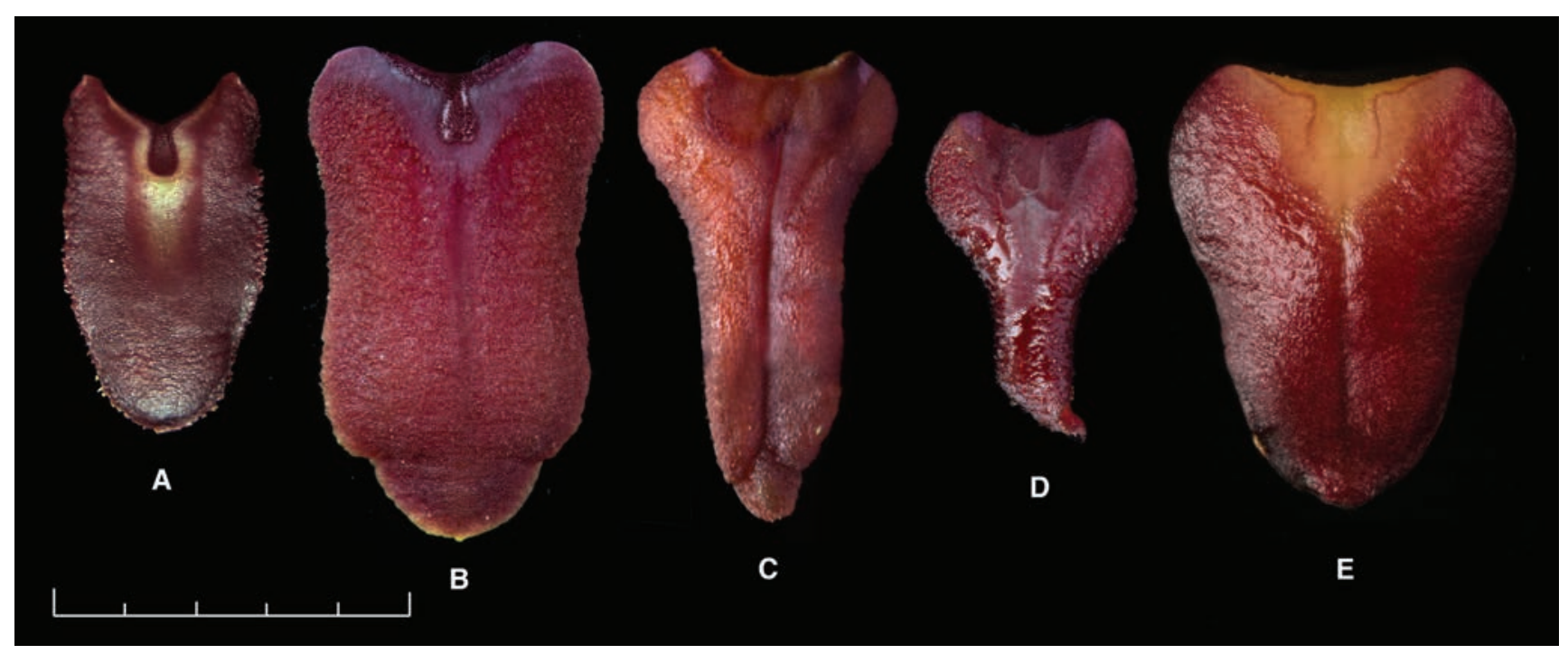

FIgURE 3. Lips of the species and nothospecies in the Pleurothallis tonduzii group. A, P. angusta (Karremans 6175); B, P. grandilingua (Bogarín 5638); C, P. tonduzii (Karremans 5840). D, P. ×parentis-certa $($ Bogarín 11802); E, $P . \times$ karremansiana $($ Díaz 270). Scale bar $=$ $5 \mathrm{~mm}$. All the vouchers at JBL. Photographs by F. Pupulin (A-C, E) and D. Bogarín (D).

the lip is arrow-shaped, with the basal angles rounded, strongly conduplicate below the area of the glenion, with the two longitudinal halves slightly convex; close to the apex the blade is constricted into a small, elliptic, rounded, convex midlobe, inserted where the convex halves flush into the blade. During anthesis, whereas the base of the lip becomes slightly convex, the lateral margins fold under to touch themselves behind the lip, the blade becomes strongly geniculate at about two-thirds of its length, and the foldeddown apex twists on one side. The final shape of the lip of $P$. tonduzii represents a real challenge in conveying its complexity through descriptive terminology. According to our observations, the torsions of the lip of $P$. tonduzii are transmitted in varying degrees to its progeny. Thus, in $P$. xkarremansiana, likely a cross with a species of the $P$. cardiothallis group, the lip is conduplicate with a central depression, the margins are convex and slightly folded under, and the lamina presents a subterminal constriction with a terminal lobule. In $P$. xparentis-certa, which we interpret as a nothospecies formed by $P$. tonduzii with a species of the P. phyllocardia group, the morphology of the lip is very similar to that of the putative parent except for the much more distinct glenion, and the size that is roughly half that of the lip of P. tonduzii.

The species of the Pleurothallis palliolata group are vegetatively indistinguishable from several other mediumsized taxa with ovate leaves, which is the predominant shape in the large assemblage of species treated in this paper. The flowers of $P$. palliolata and the other morphologically similar species are, however, unique in the genus for their conspicuous, inflated, deeply concave-cucullate dorsal sepal, which is much wider than the synsepal and forms a hood over the gynostemium. In P. maduroi, which ostensibly has one of the larger flowers in the genus as far as the flora of Central America is concerned, the dorsal sepal is almost $3 \mathrm{~cm}$ wide, with 16-18 veins, and in P. palliolata it reaches $2 \mathrm{~cm}$ in width. However, notwithstanding a visual similarity in the general shape of the flowers, the three Costa Rican species in the P. palliolata group strongly differ in most of their floral details. Pleurothallis maduroi is likely the single representative in the American isthmus of a group of species mostly Andean in distribution, which we hypothesize are phylogenetically closely related, including $P$. gargantua Luer, P. imperialis Luer, P. marthae Luer \& Escobar, and $P$. teaguei Luer. In all these species, the flowers are large if not gargantuan, provided with a rounded and comparatively large lip and wide, rectangular, twisted petals, which probably play a specific role in their pollination syndrome. Pleurothallis palliolata also has large flowers and a rounded lip, but the petals are narrow and incurved, more similar in structure to those of the South American P. corysta Luer, $P$. hoeijeri Luer \& Hirtz, and P. quitu-cara Carrera \& Baquero, to which it is perhaps related. Finally, P. chavezii has much smaller flowers, a long and narrow lip, and long, lanceolate petals that are borne erect and then bend abruptly, which is completely different morphologically from other species in the group and is perhaps comparable to the Ecuadorean P. megalotis Luer \& Hirtz. The broad, cucullate dorsal sepal reclined over the column is functionally analogous, but not homologous, to the deeply cymbiform synsepal, which is frequent in many unrelated species of Pleurothallis with nonresupinate flowers, not only in the MacrophyllaeFasciculatae group. We do not have a phylogenetic tree of Pleurothallis with sufficient resolution to allow plotting the systematic and evolutionary occurrence of the "cowled flowers" in the genus, but we strongly suspect that this character evolved independently several times in the entire subtribe.

Another group discussed in the present treatment is that of Pleurothallis cardiothallis Rchb.f. and its relatives, of which we recognize seven species. Pleurothallis cardiothallis is the oldest name referrable in Costa Rica to the species of this group. It was originally described from a plant without specific locality acquired in England and 


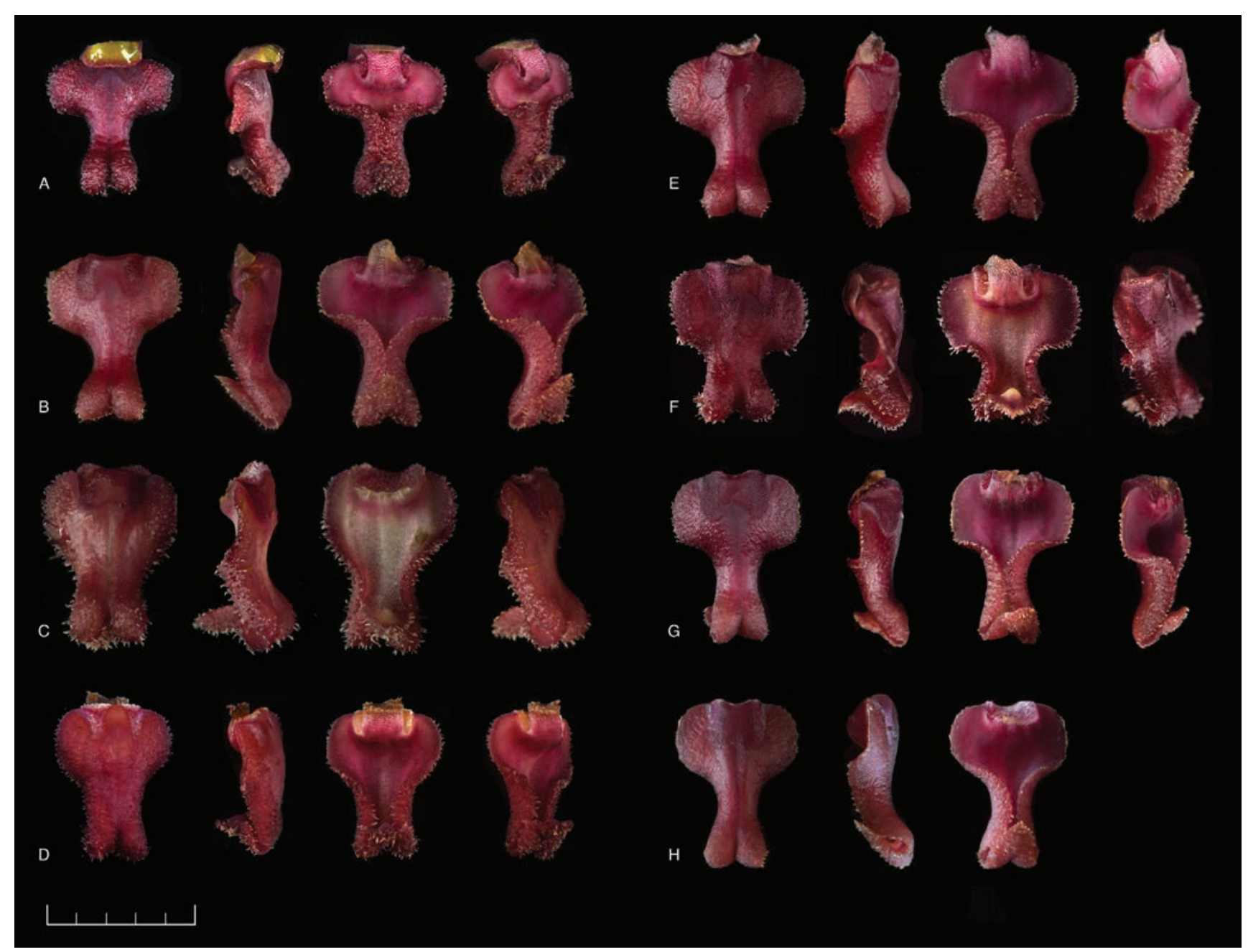

Figure 4. A-H. Morphology of the lip in Pleurothallis tonduzii. A, Bogarín 10434; B, JBL-04789; C, Serrano 154; D, Karremans 4575; E, Bogarín 3808; F, Pupulin 4389; G, Karremans 5158; H, JBL-04793. Scale bar $=5 \mathrm{~mm}$. All the vouchers at JBL. Photographs by F. Pupulin.

cultivated in Hamburg by Consul Gustav Wilhelm Schiller (Reichenbach, 1857). Plants of the $P$. cardiothallis group are among the largest Pleurothallid orchids in the flora of Costa Rica: they have large, ovate, flexible leaves, deeply cordate at the base and with the basal margins mostly overlapping at maturity. The adaxial surface of the leaves is distinctly matte, often with the main veins slightly protruding. The flowers of species belonging to this group are unique among Costa Rican Pleurothallidinae in their delicate and usually large flowers with distinct temporal activity. The perianth reaches incomplete anthesis during the first day, and then it closes before night, to re-open the next morning when it almost completely spreads. Complete anthesis is usually reached during the third or fourth day of flowering, when in some species the sepals and petals become fully reflexed. At the end of the fifth to eighth day of intermittent anthesis, the flower withers and detaches from the pedicel (Fig. 5).

A fourth group of species is mostly characterized by the inflorescence produced from an erect to suberect spathaceous bract, with flowers that do not exhibit temporal activity. Pleurothallis phyllocardia Rchb.f. represents the oldest name in this group, and it was proposed from a plant collected by Herman Wendland in Costa Rica (Reichenbach, 1866). The group is treated here as encompassing 11 species in Costa Rica. Most of the species of the P. phyllocardia group present an erect or suberect spathaceous bract at the base of the leaf that protects the developing inflorescences, and even though this character is not consistent throughout all the species, the erect spathe has not been recorded outside this group. In most species of the $P$. phyllocardia group, the margins of the sepals are completely reflexed at maturity; in several species the petals strongly curve back immediately after the flower opens. Anthesis of individual flowers in the group spans 6 to 8 days. Furthermore, some of the species are unique in Pleurothallis in the fact that, after anthesis, the pedicel becomes strongly geniculate, forcing the flowers to face down toward the leaf. So, even when the flowers open erect once exerted from the spathaceous bract, they eventually recline over the leaf, leaving a relatively small space open between the column and the leaf surface. It may be that this particular arrangement of the flowers, which is unique to this group and which we documented 


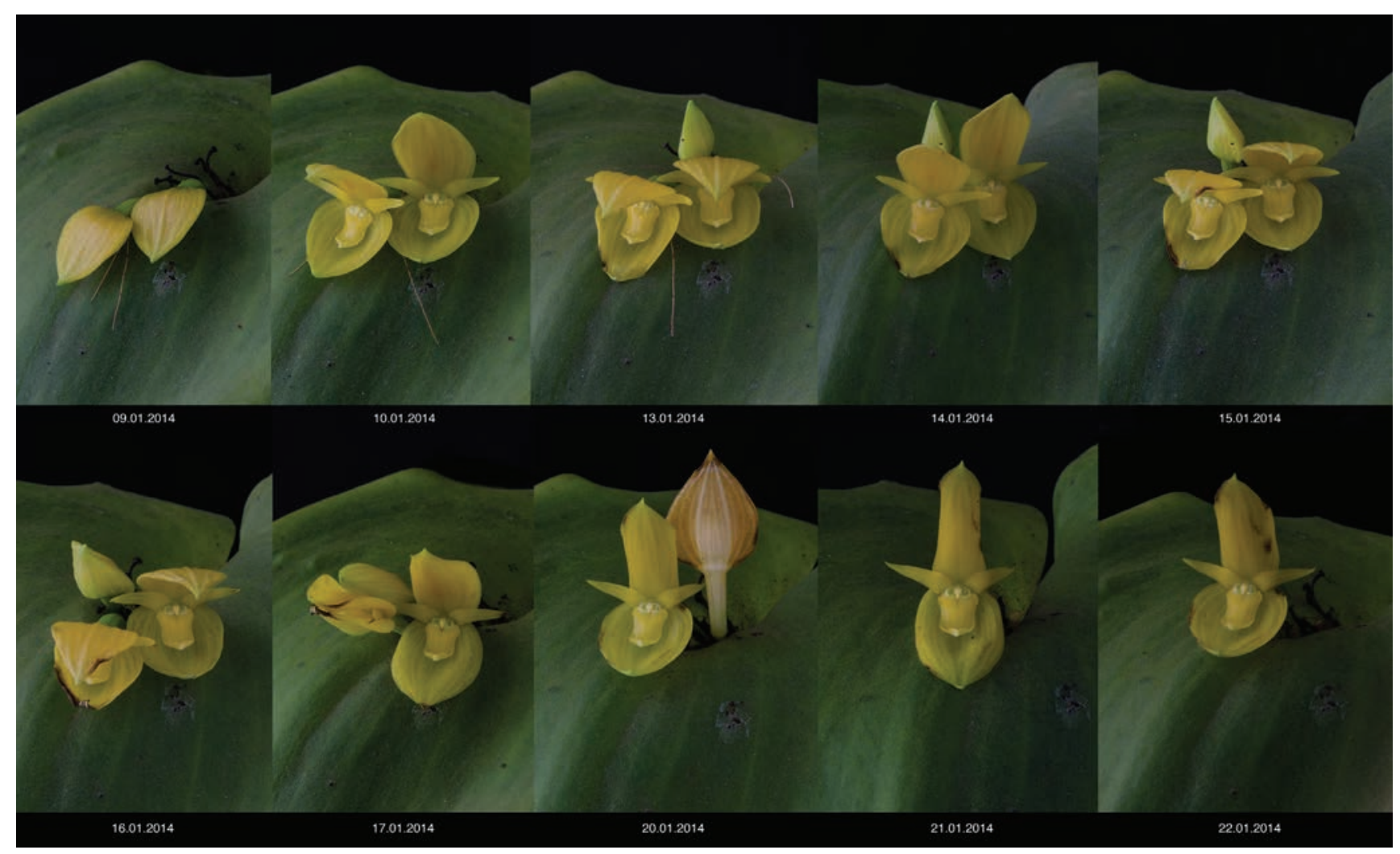

FIGURE 5. Temporal activity on flower of Pleurothallis cardiothallis (from Pupulin, Díaz-Morales, Aguilar, et al., 2017). Flower in the foreground is at the third day of anthesis on 01.09.2017; it partially opens and closes during the next six days, until it fades on 01.18. Flower in the background begins anthesis on 01.10 and opens and closes during the next 10 days until it fades on 01.20. A new floral bud is partially developed on 01.13; it begins anthesis on 01.20 and reaches its fully spread shape on 01.21, then partially closes on 01.22 . All the photographs taken approximately at 9:00 AM. Voucher: F. Pupulin 6414 (JBL). Photographs by J. Aguilar. Reproduced with permission from the Editor of Lankesteriana.

in three species in Costa Rica, affects potential pollinators approaching the flowers, but we have no direct observations of pollinator behavior on the flowers to support this hypothesis. In most species of the $P$. phyllocardia group, juvenile leaves are cuneate or rounded at the base, and basally deeply cordate leaves are associated with mature, flowering stems. We interpret the cuneate leaves on fertile stems of $P$. fantastica as a retention of the paedomorphic form, which is otherwise characteristic of the juvenile stage within the group.

The Pleurothallis phyllocardia group also includes some species of Pleurothallis that do not fit well in it or in any of the artificial groups defined by particular features. Nonetheless, they are closer to the assemblage of species discussed here than to any other group within the genus, at least in the flora of Costa Rica. They are tall species of Pleurothallis, with terete stems and fasciculate flowers produced above the leaf from a spathe, but they have narrow, acuminate leaves, a prostrate spathe, erect flowers without temporal activity, a flat dorsal sepal similar in size to the synsepal, and a somewhat bizarre floral morphology as compared with other Costa Rican taxa in this large group of Pleurothallis. The deeply three-lobed lip of $P$. fantastica, with the erect lateral lobes much larger than the reduced, almost vestigial midlobe, is highly anomalous in Pleurothallis. Pleurothallis fantastica is also the only species treated here in which leaves are cuneate - instead of cordate - at the base. We suggested above that this represents the retention of a paedomorphic character, which is common in immature leaves throughout the other sampled taxa of the $P$. phyllocardia group. Pleurothallis adventurae and $P$. peculiaris apparently represent misfits in this treatment, but nonetheless they most firmly belong in the $P$. phyllocardia group. This affinity is difficult to visualize when arranging the species of Costa Rica in discrete groups on the basis of shared morphological characteristics, but it becomes boldly apparent when other taxa from South American floras are added to the analysis. Two of us (MD, FP) had the opportunity to revise in depth a very large sample of Andean taxa morphologically close to $P$. adventurae and $P$. peculiaris (virtually including all the hitherto known species). When the entire series is taken into account, it becomes apparent that species with erect spathes-close to $P$. phyllocardia-blend via $P$. peculiaris and other similar taxa into a group of South American species with both erect and supine spathes, glaucous, dark green, narrow leaves, and dark red-purple flowers frequently with scabrous to hirsute indumenta, which are morphologically very similar to $P$. adventurae. Such a broad comparison is, nonetheless, outside the scope of the present work. The inclusion of $P$. adventurae and $P$. peculiaris in 
the Costa Rican group of species close to P. phyllocardia is based therefore on a broader understanding of the genus, even though it makes it more difficult to characterize the group based on any possible sets of shared features.

\section{Diversity}

In the present systematic treatment, we recognize 30 taxa in a group that had traditionally included 14 species recorded for the flora of Costa Rica with a similar circumscription of taxa. This increase in recorded diversity, more than doubling the number of taxa in the assemblage of species as defined in this study, is the direct result of research initiated by our group almost 10 years ago (Karremans and Bogarín, 2011; Karremans and Muñoz García, 2011; Pupulin, DíazMorales, Aguilar, et al., 2017; Pupulin, Díaz-Morales, Fernández, et al., 2017; Pridgeon, 2020), as well as of the methodology employed in this study.

The oldest taxa in the group were described by Reichenbach $(1857,1866)$, on the basis of dried specimens and sometimes without specific locality data. Several morphological details that are critical to fully understanding individual characteristics and species circumscriptions are for the most part impossible to be interpreted in pressed and distorted material. Floral features that are likely a response to environmental factors, like the temporal activity of the perianth and its shape at maturity, cannot be observed, of course, in conserved flowers. This traditional way of studying pressed Pleurothallis specimens collected by others continued with the work of Schlechter (1918) and Ames and collaborators, who added a few more species to the group (Ames, 1922, 1936; Ames and Schweinfurth, 1925). It was not until the seminal works by Luer on the Pleurothallidinae, however, that the diversity of Pleurothallis in this large and complex group of species could be studied for the first time through the analysis of living specimens, fresh flowers, and pickled vouchers kept in alcohol to preserve their tridimensionality. Luer thereby significantly increased our knowledge of Pleurothallis species native to Costa Rica and produced much more detailed and truthful descriptions and accurate illustrations, but he was nonetheless limited by the relatively sparse botanical sampling he was able to do personally during his visits to the country (Luer, 1979, 1996, 1997).

In the last 15 years or so, we have amassed in the living collections of JBL a large number of specimens of Pleurothallis from a broad range of localities, spanning most of the geographical, altitudinal, and ecological regions of Costa Rica. When plants flowered, most of them were fully documented in LCDPs, and they were photographed at maximal development to record floral shape, dimensions, and colors. Hundreds of vouchers were conserved in the ancillary spirit and DNA collections of the center. Data on phenology and floral behavior were collected and sometimes photographically recorded over several years, and observations and measurements of vegetative and floral parts were made under uniform greenhouse conditions to reduce to a minimum those individual variations produced by environmental factors. There is probably no other way to attain a sound preliminary framework of diversity in a given group that could take into account the variation expected in nature within and among populations of the studied species, independent of nomenclature matters. It is, of course, a method that can be applied only to a local flora, with the support of legal permits that allow collecting a certain number of specimens of any morphospecies or working taxonomic unit, and a permanent place for cultivation.

Systematic work in groups as large and complex as Pleurothallis benefits from the identification of smaller taxonomic units, whose diversity can be more easily investigated piecemeal. Even if these taxonomic units do not in any way represent an attempt to be recognized in a formal hierarchical system, nevertheless, they do not even constitute a simple artificial grouping scheme. They correspond in fact to a selective profile made on the basis of taxonomically significant characters and, in many cases, of synapomorphic characters that are unique and specific for each unit. As such, they underline the possible belonging of the species included in each group to a particular lineage according to a phylogenetic perspective.

Given the increasing diversity in the group revealed by our study, and the relatively restricted geographical distributions known for some of the taxa-which are endemic to one or a few mountain ranges - it is possible that our horizontal sampling over the entire country of Costa Rica was less complete than desirable. We are nonetheless confident that our sampling in favorable habitats was robust and that the number of specimens studied and documented for this paper offer future students a valuable comparative basis for the recognition of possible novelties in the group and for placing them into a correct systematic and phylogenetic frame.

\section{Ecology}

With their narrow stems and soft, subcoriaceous leaves, most species in the group inhabit the premontane and lower montane forests along all the major Costa Rican cordilleras, where the mild to cool climate and humid environmental conditions that prevail throughout the year prevent desiccation of the plants in their epiphytic habitat. With the notable exception of Pleurothallis cardiothallis, whose populations may be found as low as $350 \mathrm{~m}$ above sea level (a.s.l.), all taxa are restricted in vertical distribution above $700 \mathrm{~m}$. Species diversity significantly increases above 1000 $\mathrm{m}$, reaching a peak at the elevational gradient of $1300-1400$ $\mathrm{m}$, where $60 \%$ of the taxa (18 species) are found (Fig. 6). Diversity decreases over $2000 \mathrm{~m}$, and only a single species (P. longipetala) may be found above $2400 \mathrm{~m}$ in elevation. No species of this group have been found over $2800 \mathrm{~m}$.

The highest concentration of species in Costa Rica is found along the Cordillera de Talamanca, which spans from the Chiriquí region in Panama to the eastern end of the Central Valley in Costa Rica. Here the spine of the Continental Divide transforms into the young mountain system of the Cordillera Volcánica Central and, northward, into the relatively low Cordillera de Tilarán and the northern Cordillera Volcánica de Guanacaste. Species diversity in 


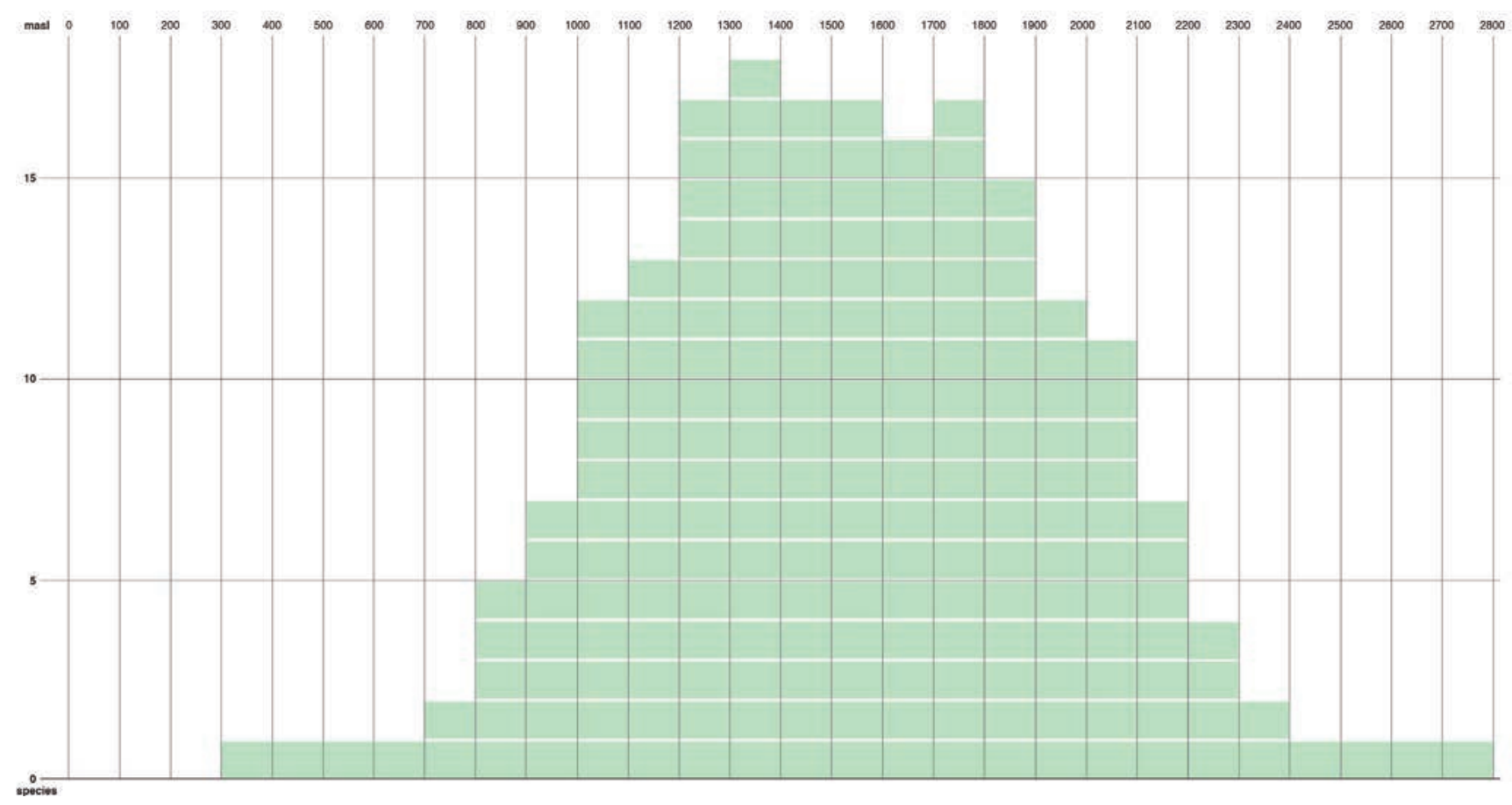

FiguRE 6. Elevational distribution of taxa in the Pleurothallis cardiothallis group. $\mathrm{x}$-axis $=$ elevation; $\mathrm{y}$-axis $=$ number of species.

the study group progressively diminishes toward the north, likely reflecting an ancient Andean origin of the group and its immigration from northern South America via the Panamanian isthmus.

While populations of Pleurothallis cardiothallis, $P$. longipetala, P. phyllocardia, and P. tonduzii are known from both watersheds of the Continental Divide, most species in the group are restricted to only one side of the mountain chains that longitudinally cross the country, with a majority of taxa confined to the wetter environments of the Caribbean watershed. Interestingly, except for the species close to $P$. palliolata, which are exclusively Caribbean in distribution, all the other groups treated here present "sister" species on both sides of the continental divide. So, $P$. angusta, $P$. callosa, $P$. compressa, $P$. chavezii, $P$. gonzaleziorum, $P$. $\times$ karremansiana, P. maduroi, P. navisepala, P. oncoglossa, $P$.palliolata, and $P$.tapantiensis are exclusively found along the slopes of the Costa Rican chain that face the Caribbean Sea, while populations of $P$. grandiflora and $P$. scotinantha are seemingly restricted to the Pacific side. The apparently rare $P$. anthurioides has been collected in Costa Rica so far only on the Pacific watershed of the Cordillera de Talamanca, but the type specimen was allegedly found on the Caribbean side of the same mountain chain in Panama. Concerning life zones, most of the species $(20 \mathrm{spp} .=66 \%)$ are found in the moist and wet premontane forests, followed by the wet lower montane forests $(18 \mathrm{spp} .=60 \%)$, the montane forest at elevations higher than $2000 \mathrm{~m}(7 \mathrm{spp} .=23 \%)$, and the tropical forest of the basal belt (only a single species $=3 \%$ ).

Phenologically, the species of the group present flowers most of the year. However, a graph that shows the number of species in flower by month (Table 1) clearly reveals that the flowering of these taxa is mostly associated with seasonality. Flowering shows a peak in the wettest month, November, when $65 \%$ of the taxa are in flower (19 species), and a progressive diminishing of flowering during the driest months to a low of only 5 species in flower (ca. 17\%) during April, at the end of the dry season.

\section{Floral Ecology}

The floral ecology of species in the Pleurothallis cardiothallis group was first addressed by Pupulin, DíazMorales, Aguilar, et al. (2017), who tentatively associated flower longevity and periodicity in species belonging to the group with reduction of transpirational water loss. While flower lifespan in the Pleurothallidinae may be extremely short (1-2 days in Specklinia colombiana [Garay] Pridgeon $\&$ W.M. Chase) or unusually long (to 30 days in Diodonopsis erinacea [Rchb.f.] Pridgeon \& M.W. Chase and, according to literature, up to 3 months in Lepanthes escobariana Garay [di Vita, 2017]), most genera and species in the subtribe have anthesis periods of 7-15 days (pers. observ.). The lifespan of flowers in species close to $P$. cardiothallis is usually 7-10 days, which is about average in both the subtribe and the genus. As the glenion at the base of the lip likely acts as a deceptive lure for potential pollinators, a relatively long flower lifespan may effectively increase the chances of visitation, and this trait has been effectively associated with deceit-pollination species (Internicola and Harder, 2012).

Unlike other species of Pleurothallis, taxa in the $P$. cardiothallis group are invariably characterized by short daily activity in the flowers. To date, we have observed only temporal activity in flowers of this group, and we consider that this trait has taxonomic significance. In the flowers of most species in the P. cardiothallis group, the two 


\begin{tabular}{|c|c|c|c|c|c|c|c|c|c|c|c|c|}
\hline & Jan & Feb & Mar & Apr & May & Jun & Jul & Aug & Sep & Oct & Nov & Dec \\
\hline 1. P. angusta & & & & & & & & & & & & \\
\hline 2. P. grandilingua & & & & & & & & & & & & \\
\hline 3. $P . \times$ karremansiana & & & & & & & & & & & & \\
\hline 4. $P \times$ parentis-certa & & & & & & & & & & & & \\
\hline 5. P. tonduzii & & & & & & & & & & & & \\
\hline 6. P. chavezii & & & & & & & & & & & & \\
\hline 7. P. maduroi & & & & & & & & & & & & \\
\hline 8. P. palliolata & & & & & & & & & & & & \\
\hline 9. P. callosa & & & & & & & & & & & & \\
\hline 10. P. cardiothallis & & & & & & & & & & & & \\
\hline 11. P. gonzaleziorum & & & & & & & & & & & & \\
\hline 12. P. navisepala & & & & & & & & & & & & \\
\hline 13. P. oncoglossa & & & & & & & & & & & & \\
\hline 14. P. scotinantha & & & & & & & & & & & & \\
\hline 15. P. tapantiensis & & & & & & & & & & & & \\
\hline 16. P. anthurioides & & & & & & & & & & & & \\
\hline 17. P. compressa & & & & & & & & & & & & \\
\hline 18. P. longipetala & & & & & & & & & & & & \\
\hline 19. P. luna-crescens & & & & & & & & & & & & \\
\hline 20. P. mesopotamica & & & & & & & & & & & & \\
\hline 21. P. phyllocardia & & & & & & & & & & & & \\
\hline 22. P. pudica & & & & & & & & & & & & \\
\hline 23. P. radula & & & & & & & & & & & & \\
\hline 24. P. rectipetala & & & & & & & & & & & & \\
\hline 25. $P . \times$ silvae-pacis & & & & & & & & & & & & \\
\hline 26. $P \times$ subversa & & & & & & & & & & & & \\
\hline 27. P. triangulabia & & & & & & & & & & & & \\
\hline 28. P. adventurae & & & & & & & & & & & & \\
\hline 29. P. fantastica & & & & & & & & & & & & \\
\hline 30. P. peculiaris & & & & & & & & & & & & \\
\hline & & & & & & & & & & & & \\
\hline Curve of flowering per number of species & & & & & & & & & & & & \\
\hline
\end{tabular}

TABle 1. Phenological records relatives to the species of Pleurothallis discussed in this paper. Data from field observations and plants grown at the Lankester Botanical Garden.

labia formed by the sepals are slightly to deeply concave at maturity, while the petals are completely extended and straight. In $P$. cardiothallis and P. tapantiensis, however, the lateral margins of the sepals and the apex of the petals continue extending backward until they are completely reflexed. In all the species of the group, during the late hours of the morning and at noon, likely as a response to the decreasing humidity of the environment, the tip of the petals begins curving toward the column, while the dorsal sepal and synsepal progressively approach each other until the perianth completely closes. This activity of the perianth repeats daily, even though on particularly hot and dry days the flowers may not spread out completely. At evening, they are regularly closed, at least partially. During rainy days, the flowers remain active for longer periods, and on several occasions, the closure of the perianth is not complete. Intermittent anthesis of individual flowers can continue for up to 8 days, after which the flowers definitively closes and, unless pollinated, the perianth plus the ovary detach from the pedicel. Floral activity in P. cardiothallis has been photographically documented in Pupulin, Díaz-Morales, Aguilar, et al. (2017) (Fig. 5).

Intermittent anthesis has never been observed in taxa belonging to the so-called "frog" group of Pleurothallis, which are phylogenetically close. Species of the latter group invariably have distinctly smaller flowers, however, and this seems to support the hypothesis that temporal activity of the perianth in larger flowers is aimed at reducing water loss in delicate floral tissues. We have not encountered floral scents perceivable by the human nose, but we cannot exclude the possibility that particular regions of the perianth can produce volatile substances to which visitors are attracted. In this case, shorter periods of flower activity during the total time of potential anthesis could also reduce metabolic costs.

Santos and Presley (2010) and Aguiar et al. (2013) have suggested that short flower activity may represent a temporal niche, aimed at reducing competition with other species that occupy the same habitat, rely on the same pollinators, and are active at different times. This scenario is however unlike that observed in our study group. According to Karremans and Díaz-Morales (2019), Pleurothallidinae is the largest fly-pollinated group in Orchidaceae, with at least 15 genera presenting a myophilous pollination syndrome. Within Pleurothallis, 11 different families of Diptera have been recorded as flower visitors, with a majority of species belonging to Sciaridae (recorded in 11 species of Pleurothallis) and Drosophilidae (in 6 species) (Karremans and Díaz-Morales, 2019). Potential pollinators 
have been observed for only 8 species of Pleurothallis of the Macrophyllae-Fasciculatae group (including 2 of the species treated in this paper, $P$. navisepala and $P$. phyllocardia), and they also mostly belong to the families Sciaridae and Drosophilidae. Flowers are visited by several different flies, which apparently attempt to reach the rounded glenion at the base of the lip. When the insect touches the viscidium placed above the glenion, the pollinia are removed and adhere to the head (more rarely to the leg) of the visitor. Even though it is still unclear if this simple mechanism makes Pleurothallis a truly generalist group in terms of pollination, it is nonetheless clear that the interaction between glenion and apical anther/stigma allows for the pollinator group to be less specific than in genera in which a more precise fit is required between insect and flower (Karremans and Díaz-Morales, 2019). Furthermore, small flies are active during most of the day, often irrespective of the weather conditions, and pollination of Pleurothallis by Mycetophilidae and Sciaridae has been documented to be even nocturnal (Duque-Buitrago et al., 2014), which makes it hard to interpret intermittent anthesis in terms of a temporal pollination niche.

\section{Color Dimorphism}

In the group of Pleurothallis species discussed here, the flowers are mostly purple, sometimes with an orange-purple background and darker purple stripes around the veins. The purple color is often very dark, in some of the taxa almost blackish, and the lip is often very dark, including in those species that have lighter-colored sepals and petals. As the flowers of this group of species do not emit any fragrance that is perceivable by the human nose, the widespread occurrence of this dull color throughout the entire group is perhaps suggesting that this particular tone is in some way associated with visual preferences of pollinators, which could be lured to visit the flowers through a visual signal. Noteworthy, however, is the relative frequency of entirely yellow flowers in individuals of several typically purpleflowered species treated in this study. Species dimorphism in flower color, with the frequent occurrence of entirely yellow flowers among typically purple-colored populations, has been documented in other advanced orchid groups as well (Pupulin, 2003; Pupulin and Rojas, 2006). In those groups, however, the yellow phase is likely associated with a specific pollination syndrome. In the species close to Oncidium guatemalenoides M.W. Chase \& N.H. Williams (in the Sigmatostalix group), which have flowers normally boldly blotched with purple, all the taxa also present individuals with concolorous, bright yellow flowers. As these flowers are pollinated by bees foraging for nectar and oils, this color shift may represent an advantage in terms of attracting possible visitors. Papadopulos et al. (2013) have shown that yellow-flowered species in the Oncidiinae occupy a distinct portion of color space in the color vision of Hymenopterans when the insects approach floral communities, and that floral reflectance of yellow Oncidiinae flowers closely mimics the floral signals of rewarding Malpighiaceae. While this suggests that a shift toward concolorous yellow flowers likely represents an enhancement of the mimic model syndrome in the Oncidiinae, no evidence allows us to extrapolate this phenomenon to Pleurothallis since the species of this genus are mostly visited by Dipterans, which perceive visual signals in a very different way than Hymenopterans. Nonetheless, the color dimorphism associated with several species of the group treated here is noteworthy. Such dimorphism is not unique to this group and is quite widespread in the genus: we observed it as a frequent variation throughout the Macrophyllae-Fasciculatae group, as well as in the "Mesoamerican group" of species sensu Wilson, Belle, et al. (2013) and Wilson, Pupulin, et al. (2013) (Pupulin et al., unpubl. data). In our species group, all the taxa close to $P$. cardiothallis exhibit a yellow phase together with the typical purple one. Among species of the P. phyllocardia group, which are invariably purple to blackish purple, a single species, $P$. radula, has concolorous yellow flowers. In this species, we also documented a form with rose apices of the sepals, which seem to clearly indicate the presence of unexpressed anthocyanins in the flowers (Fig. 7). Flowers with yellow sepals are also known among the mostly lightto dark-purple flowers in P. tonduzii (Fig. 8). The frequency of the yellow phase among populations with mostly darkpurple flowers, as well as the production of capsules in a wild population of $P$. radula with flowers of the rose phase, suggests that these variations are equally visited by their pollinators and reproductively functional.

\section{Natural Hybridization}

It seems of particular interest that 4 out of 30 taxa (= $13 \%$ ) of the group studied for this monograph are most surely of hybrid origin, while others (like P. grandilingua) present some features that are somewhat intermediate between species of the group and perhaps represent vestigial characters of ancient hybridization processes. Considering the highly random possibility of finding and collecting a hybrid plant in the field, as well as the highly scattered spatial distribution of hybrid individuals that could be reproductively nonfunctional, the percentage of natural hybrids documented for this study suggests that their occurrence, in the midst of parent populations, could be much more frequent than expected. It is not fortuitous that two of the four nothospecies recorded in our study were originally described from Bosque de Paz Biological Reserve. Longterm studies carried out at the reserve (Kirby, 2003; Kirby and Muñoz, 2007; Muñoz and Kirby, 2007; Karremans and Muñoz García, 2011; Bogarín et al., 2015; Díaz-Morales and Karremans, 2015; Belfort-Oconitrillo, in prep.), documenting not only species diversity but also phenotypic and individual variations between and within populations, have increased the probability of coming across scattered individuals of putative hybrid origin. The case of Bosque de Paz shows how vertical and thorough local sampling is likely the only viable strategy that can allow us to understand the possible role of hybridization in shaping the extraordinary variability of some characters in Pleurothallis and correctly distinguish between good species and the products of hybridization with successive introgressions.

The relatively high number of natural hybrids we documented for this study also raises the question of how much gene flow between species may have contributed to the actual diversity of the Pleurothallis group and perhaps to the overall diversity of the genus. The apparently unspecialized pollination system of Pleurothallis probably results in the 


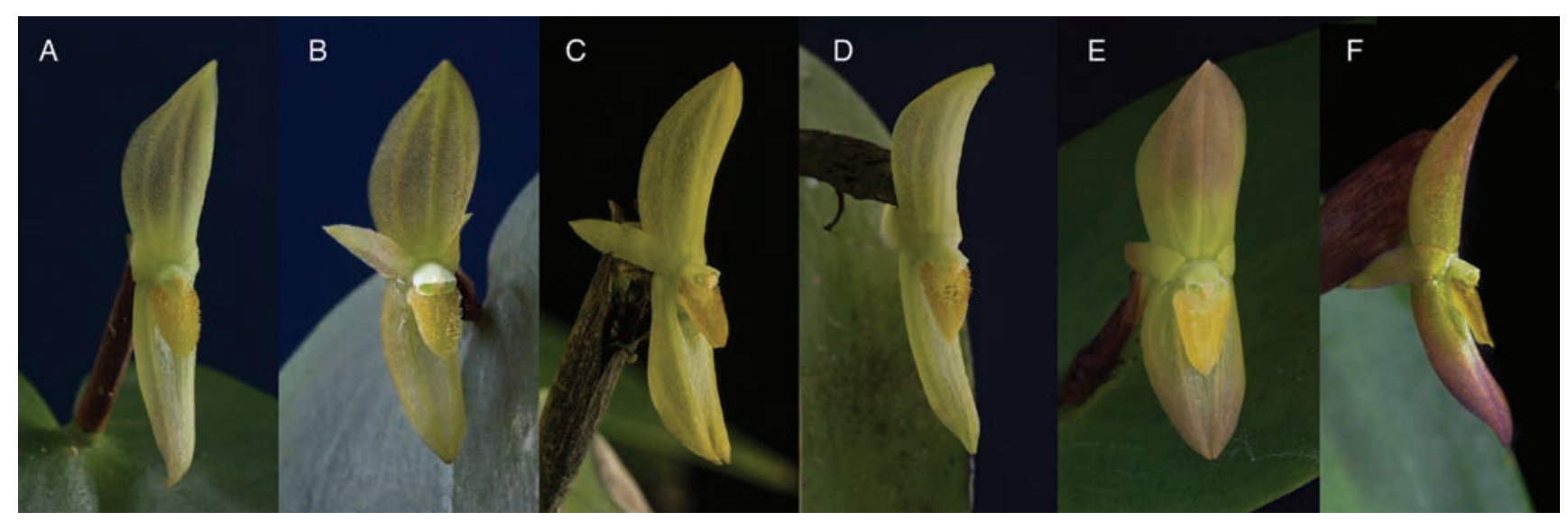

FIgURe 7. Color variation in flowers of Pleurothallis radula. A, Pupulin 8130; B, Pupulin 7796; C, Díaz 385; D, Karremans 5161; E, Pupulin 8129; F, Belfort-Oconitrillo569. All the flowers at the same scale. Vouchers at JBL. Photographs by F. Pupulin (A-E) and N. Belfort-Oconitrillo (F).

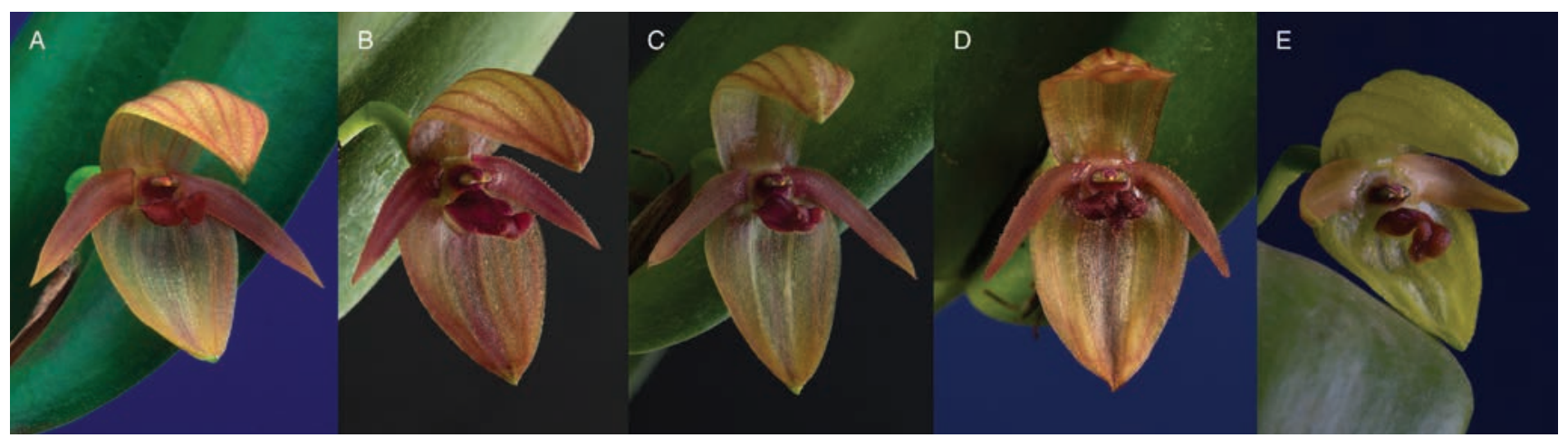

Figure 8. Color variation in flowers of P. tonduzii. A, Pupulin 549; B, JBL-02515; C, JBL-02455; D, Bogarín 10434; E, Karremans 5840. All the flowers at the same scale. Vouchers at JBL. Photographs by F. Pupulin.

occasional deposition of pollen on the "wrong" stigma. Karremans and Díaz-Morales's 2019 review of pollination in the Pleurothallidinae records no fewer than 11 families of flies (Diptera) as visitors of Pleurothallis flowers, with members of 8 families observed removing pollinaria. In the subgroup of species belonging to our study group, flowers are visited by various fly species of the families Calyptratae, Drosophilidae, Phoridae, Sciaridae, and Tephritidae (Karremans and Díaz-Morales, 2019), which remove flower pollinaria while walking on the flowers. The apical position of the anther and the rostellum pointing forward at the apex of a short column favor the placement of the droplike viscidium on the head (more rarely on the legs) of the fly, while the frontal position of the broad stigmatic cavity, filled with abundant fluid, makes the deposition of pollinaria easy even during short and occasional visits. Karremans and Díaz-Morales (2019) speculated that this relatively unspecialized but efficient mechanism allows the pollinator group to be less delimited in this genus than in other Pleurothallid genera, which require a more precise mechanical interaction between the flower and the insect body, suggesting that Pleurothallis species may be true generalists in their pollination system. Such hypothetical generalism would also favor the occasional transference of pollen between species that present the same "open system" of pollination because of the relative facility for the opportunist visitor to enter in contact with the viscidium of the pollinarium and to deposit it on the broad and prominent stigmatic surfaces.

\section{TAXONOMIC TREATMENT}

Key to the Species of the Pleurothallis Cardiothallis AND P. phyllocardia Groups and Other Related Groups in Costa Rica

1a. Leaves thick-coriaceous, rigid, with a distinctly protruding midvein abaxially, shiny on the upper surface, narrowly oblong-lanceolate, usually more than 6 times longer than broad $\ldots \ldots \ldots \ldots \ldots \ldots \ldots \ldots \ldots \ldots \ldots \ldots \ldots \ldots \ldots \ldots \ldots \ldots \ldots \ldots \ldots$ (P. tonduzii group) 2

1b. Leaves soft-coriaceous, elastic, without distinctly protruding midvein, matte on upper surface, ovate to lanceolate, usually less than 4 times

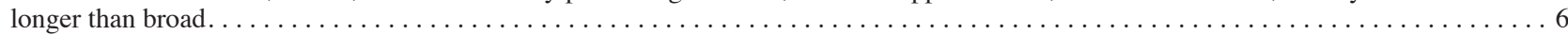

2a. Lip with the lateral margins strongly revolute, particularly in the midportion, so appearing pandurate in outline $\ldots \ldots \ldots \ldots \ldots \ldots \ldots$

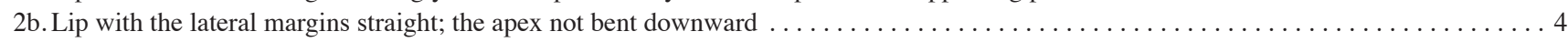
3a. Apex of lip abruptly bent upward, then strongly geniculate, twisted on one side $\ldots \ldots \ldots \ldots \ldots \ldots \ldots \ldots \ldots$. tonduzii

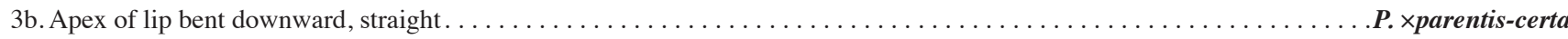




\section{Key to the SPecies of the PleURothallis CaRdiothaLLIS AND P. phyllocardia Groups and Other Related Groups in Costa Rica cont.}

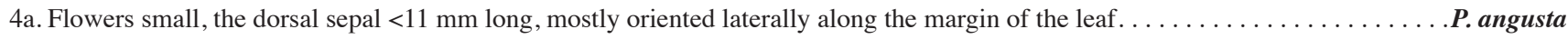

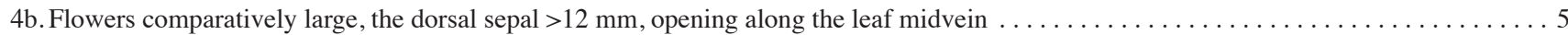
5a. Leaves thick, coriaceous; margins of petals denticulate; lip rectangular-subpandurate $\ldots \ldots \ldots \ldots \ldots \ldots \ldots$. $\ldots \ldots$ grandilingua 5b. Leaves soft, flexible; margins of petals entire; lip peltate. 6a. Dorsal sepal deeply concave, reclined over the column, much broader than the synsepal. .................. (P. palliolata group) 7

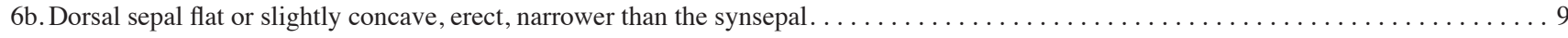

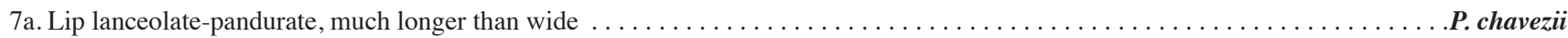

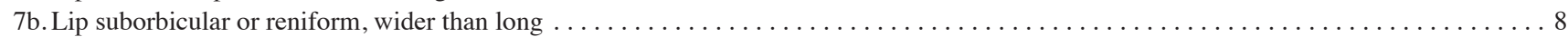

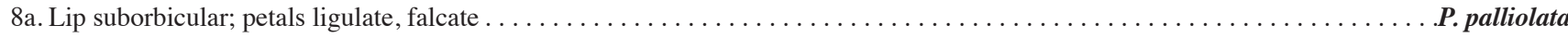

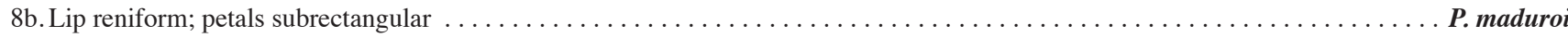

9a. Leaves large, $>5 \mathrm{~cm}$ wide; spathaceous bract always prostrate; flowers membranaceous, with distinct temporal activity, opening and closing

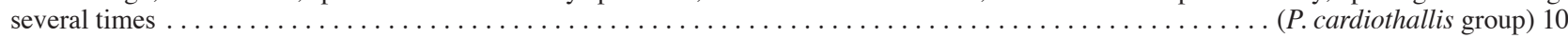

9b. Leaves narrow, $<4 \mathrm{~cm}$ wide; spathaceous bract erect to suberect, not prostrate (except in $P$. adventurae); flowers coriaceous, remaining open after anthesis . . . . . . . . phyllocardia group) 16

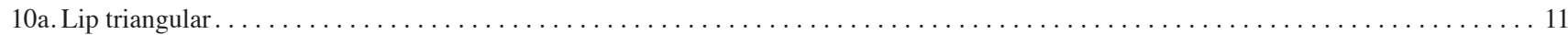

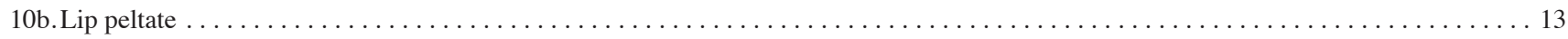

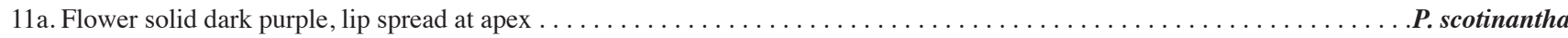

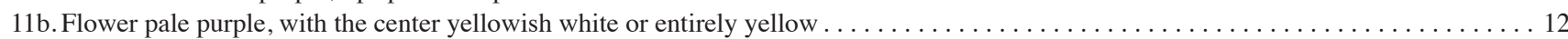

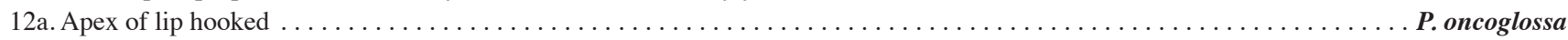

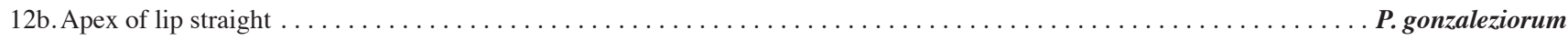

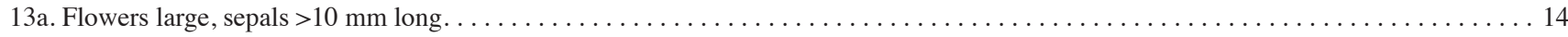

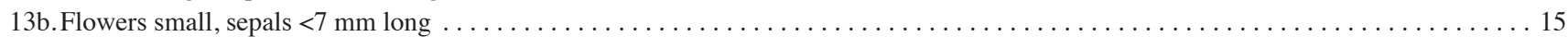

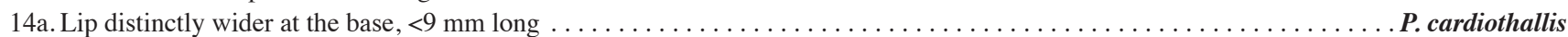

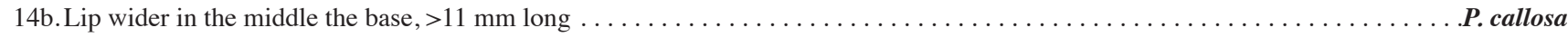

15a. Ramicauls with sheaths only at the base; flowers solitary; the synsepal slightly concave; dorsal sepal $\geq 10 \mathrm{~mm}$ long ...... P. tapantiensis

15b. Ramicauls with basal sheaths and a sheath close to the middle; flowers 1-3 simultaneously; the synsepal concave to almost saccate at the

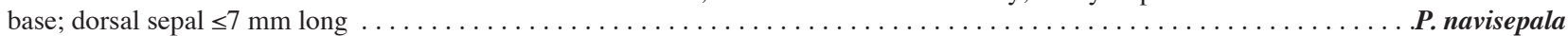

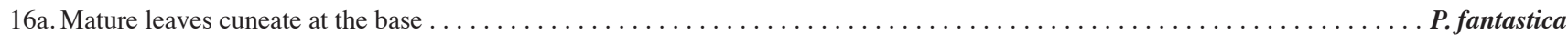
16b. Mature leaves cordate to deeply cordate at the base (immature leaves maybe cuneate), the basal margins frequently overlapping ...... 17

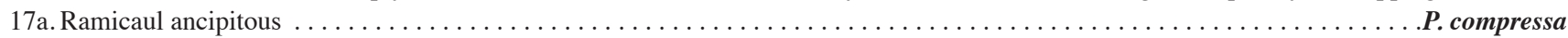

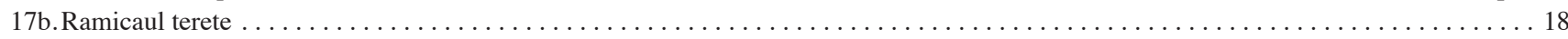

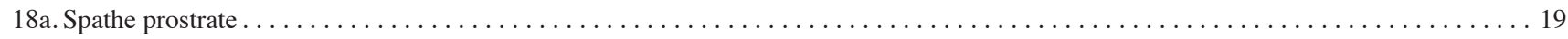

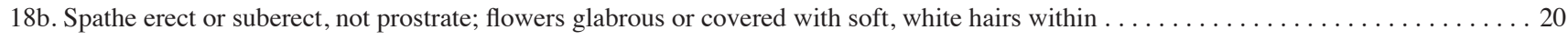

19a. Flowers resupinate, dark purple, the adaxial surface completely covered with short, stiff, pointed tubercles . . . . . . . . P. adventurae

19b. Flowers non-resupinate, bronze, the lip white apically red, the adaxial surface smooth $\ldots \ldots \ldots \ldots \ldots \ldots \ldots$. . . . . . . . $\ldots$ subrsa

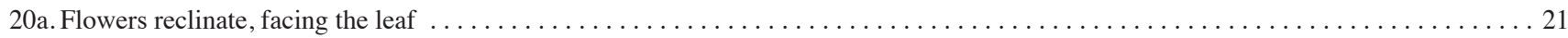

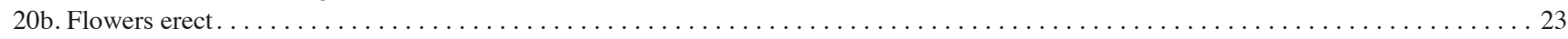

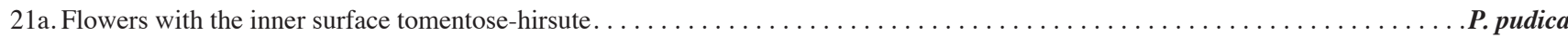

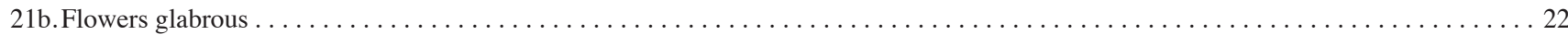

22a. Mature plant large, usually $>30 \mathrm{~cm}$ tall; dorsal sepal narrowly ovate; petals oblong; lip longer than wide . . . . . . . . . P. phyllocardia

22b. Mature plant small, usually $<20 \mathrm{~cm}$ tall; dorsal sepal elliptic-suborbicular; petals elliptic-lanceolate; lip wider than long ...P. triangulabia

23a. Flowers hairy, the dorsal sepal subcircular, the lip rhombic, with pointed lateral lobes. ..................... peculiaris

23b.Flowers glabrous, the dorsal sepal lanceolate to elliptic, the lip triangular, without pointed lateral lobes . . . . . . . . . . . 24

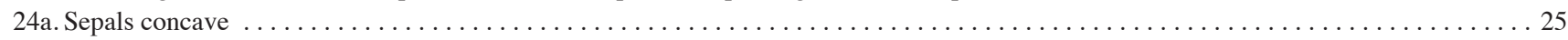

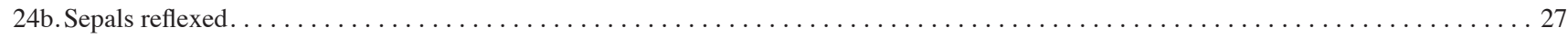

25a. Petals subfalcate, entire, pointing downward $\ldots \ldots \ldots \ldots \ldots \ldots \ldots \ldots \ldots \ldots \ldots \ldots \ldots \ldots \ldots \ldots \ldots \ldots \ldots \ldots \ldots \ldots$ anthurides

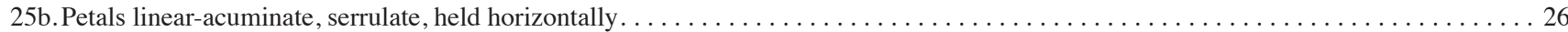

26a. Flowers with purple or dull purplish yellow, striped dark purple, $>10 \mathrm{~mm}$ long; petals purple, falcate; lip erect, pointing forward; glenion

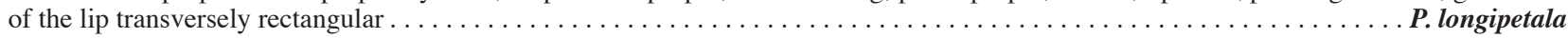

26b. Flowers with white sepals striped rose-purple, $<8 \mathrm{~mm}$ long; petals rose-purple, straight; lip reclinate, pointing downward; glenion of the lip

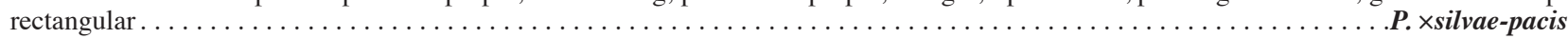

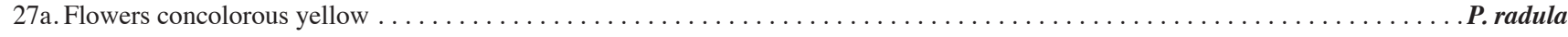

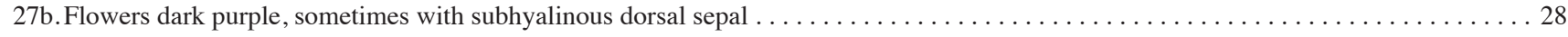

28a. Petals $>3$ times longer than broad, with dentate margins $\ldots \ldots \ldots \ldots \ldots \ldots \ldots \ldots \ldots \ldots \ldots \ldots \ldots \ldots \ldots$ luna-crescens

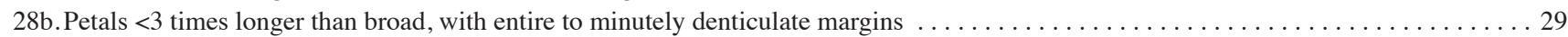

29a. Petals linear-lanceolate to linear-oblong, with minutely denticulate margins; the flowers dull purple on a yellow base; the lip papillose

29b.Petals subfalcate, with entire margins; the flowers dark-purple color; the lip verrucose 


\section{A. The Pleurothallis tonduzii group}

1. Pleurothallis angusta Ames \& C. Schweinf., Schedul. Orchid. 8: 23. 1925. TYPE: Costa Rica. [Cartago]. In cultivation at Las Concavas, May 1924, probably native of Cachí, C. H. Lankester 850 (Holotype: AMES). Fig. 9 (Voucher, Pupulin 4767, JBL).

Epiphytic, caespitose, erect to suberect herb, to $50 \mathrm{~cm}$ tall. Roots slender, flexuous, ca. $1 \mathrm{~mm}$ in diam. Ramicauls terete, slender, 24-35 cm long, 2-3 mm in diam., green suffused with dark red, provided with a tubular, short, truncate sheath to 2.5 $\mathrm{cm}$ long at the base, and a longer, tubular, tightly adpressed, obtuse sheath below the middle, to $5-7 \mathrm{~cm}$ long. Leaf borne erect at the apex of the ramicaul, becoming horizontal and revolute along the margins in the basal half with age, coriaceous, sessile, lanceolate, acute, 8.0-16.5 × 2-3 cm, cordate at the base, the midvein channeled on the adaxial surface, prominent on the abaxial surface, grass to dark green. Inflorescence a fascicle of 1-2(-7) simultaneous flowers, from a prostrate spathaceous bract ca. $1 \mathrm{~cm}$ long, brown, drypapyraceous when mature, eventually dissolving with age. Pedicel terete, pale green, 11-14 mm long, bending toward the margin of the leaf. Ovary subclavate, terete, 5-7 mm long. Flowers dark purple, suffused with yellow on the margins of the sepals and petals. Dorsal sepal ovate, acute, 10.5-11.0 $\times$ 4.5-5.0 mm, 3-veined. Lateral sepals connate into a broadly ovate, acute synsepal, 9-10 × 5-6 mm, 5-veined. Petals falcate to subovate, obtuse, $6.3-7.0 \times 1.5-2.0 \mathrm{~mm}, 1$-veined. Lip unguiculate, hinged to the column foot, geniculate, thick, ligulate, minutely ciliate, basally bilobed, obtuse, $4-5 \times 3 \mathrm{~mm}$; glenion deeply recessed between the basal lobes of the lip, ca. $0.51 \mathrm{~mm}$ long. Column short, transversely subrectangular, dorsoventrally complanate, ca. $1.2-1.8 \times 1.8 \mathrm{~mm}$, the anther apical, the stigma apical, bilobed. Anther cap obtriangular, truncate, bilobed at the base, 2-celled. Pollinia 2, narrowly oblong-pyriform, attached to an elliptic viscidium through a short, cylindric caudicula. (Fig. 10A-B).

Etymology: from the Latin angustus, "narrow," probably in reference to the narrow, oblong leaves of the species.

Distribution: Costa Rica and Panama.

Ecology: a large, suberect epiphyte spanning a broad altitudinal range, $P$. angusta has been recorded from 750 to about $2100 \mathrm{~m}$ of elevation. It is restricted to the Caribbean watershed of the Cordillera Volcánica Central and the Cordillera de Talamanca, where populations have been found in lower montane rain forests to wet montane forests. Flowering occurs from October to February, which generally corresponds to the end of the rainy season and the beginning of the dry season in Costa Rica.

Distinguishing features: the narrow, oblong, coriaceous leaf and the mostly dark-purple flowers usually facing a margin of the leaf, with a bright, shiny, ligulate lip that is ciliate along the margins, are diagnostic of the species.

Pleurothallis angusta was described from an incomplete specimen without original locality data (maybe collected in Cachí), cultivated at Las Cóncavas by Charles Lankester, and the holotype consists only of a single, sterile leaf and a portion of the subtending stem. The narrow, coriaceous leaf, as well as Ames's description of the flower (in Ames and Schweinfurth, 1925) and Lankester's notes on flower color and his crude sketch of the lip (AMES74048), unmistakably indicates the species as treated and illustrated here. Costa Rican and Panamanian populations of P. angusta have been sometimes treated as P. bivalvis Lindl. (e.g. Bogarín et al., 2014; Monro et al., 2017), but that species from northern South America (the type, Venezuela, J. Linden 1480, K) has broadly ovate leaves, and the bilabiate flowers have much broader sepals and petals with distinctly denticulate margins. Luer (2003) stated that $P$. angusta is apparently rare in Costa Rica, while it is quite common at high elevations in the Andes, but none of the materials that we had the opportunity to study from South America bear even a superficial resemblance with the true $P$. angusta, and we suspect that the records from Colombia to the south probably refer to one or more distantly related taxa.

Costa Rican material examined: Alajuela: Carrizal, Concordia, entre Los Cartagos y Cinco Esquinas, bosque pluvial montano bajo, en potreros arbolados y bosque secundario, $10^{\circ} 08^{\prime} 16.8^{\prime \prime} \mathrm{N}, 84^{\circ} 09^{\prime} 49.8^{\prime \prime} \mathrm{W}, 2027 \mathrm{~m}, 17$ junio 2009, D. Bogarín 7319, R. L. Dressler, F. Pupulin \& R. Trejos (JBL). Cartago: Jiménez, Pejibaye, Parque Nacional Tapantí, sector Taus, Selva, entre Quebrada Selva y Río Taus, 9.7875000, -83.7569444, 900-1200 m, v13 Jun 2006, J. F. Morales Quirós 14014 (CR). Jiménez, Pejibaye, Tausito, ca. $3.8 \mathrm{~km}$ después del cruce de Kiri, 946'37.8"N, $83^{\circ} 46^{\prime} 30.4^{\prime \prime} \mathrm{W}, 1281 \mathrm{~m}$, bosque pluvial premontano, epífitas en bosque secundario alterado a orillas del camino, 30 abril 2009, D. Bogarín 6990, M. Fernández, R. Gómez, Y. Kisel, F. Pupulin, P. Renshaw \& R. Trejos (JBL). Jiménez-Turrialba, La Suiza, La Suiza, Pejivalle, road to Esperanza, on hills close to Quebrada Puente, premontane wet forest, epiphytic in secondary vegetation along the sugar cane plantations, $9^{\circ} 48^{\prime} 46,0^{\prime \prime} \mathrm{N}, 83^{\circ} 39^{\prime} 10,0 " \mathrm{~W}, 750 \mathrm{~m}, 5$ Feb 2007, F. Pupulin 6498, D. Bogarín \& R. L. Dressler (JBL). Turrialba, Tayutic, Moravia de Chirripó. On the road to Platanillo, in remaining forest on the side of the road. Humid montane forest. 9 $49^{\prime} 26.07^{\prime \prime} \mathrm{N}, 83^{\circ} 25^{\prime} 27.30^{\prime \prime} \mathrm{W}, 1160 \mathrm{~m}, 15$ December 2013, A. Karremans 6175 \& M. Contreras Fernández. (JBL); Tayutic, Jicotea, Finca La Pradera, epífitas en vegetación madura a orillas de una quebrada, $9^{\circ} 47^{\prime} 06.79^{\prime \prime} \mathrm{N}$, 8332'49.48"W, 1073 m, 22 Sep 2016, A. P. Karremans 7347, I. Chinchilla, M. Díaz \& G. Rojas-Alvarado (JBL). Turrialba, Moravia de Chirripó, hills north of Moravia across the plain with pasture, premontane wet forest, secondary mature vegetation and remnants of secondary vegetation in pastures, 9 $50^{\prime} 18^{\prime \prime} \mathrm{N}, 83^{\circ} 26^{\prime} 45^{\prime \prime} \mathrm{W}, 1135 \mathrm{~m}, 12$ Jun 2002, $F$. Pupulin 3895, M. Bonilla, R. Gómez, H. León-Páez \& W. Schug (JBL); Turrialba, La Suiza, Llanos del Quetzal, ca. $1 \mathrm{~km}$ sobre el camino detrás de la Escuela de Kabébata (Alto Quetzal), 946'43.6"N, 83²4'41.6"W, 1449 m, epífitas en bosque primario y secundario, bosque muy húmedo premontano "supra arbores in nemoribus Llanos del Quetzal ad Turrialba in Cartago," 17 Junio 2011, D. Bogarín 8860, M. Fernández \& A. Karremans (JBL); same collecting data, D. Bogarín 8863, M. Fernández \& A. Karremans (JBL); Turrialba: Tuís, Cien Manzanas, 951'25"N, 83³3'47"W, ca. $950 \mathrm{~m}$, along a minor tributary of Río Pacuare, premontane wet forest, secondary vegetation and remnants of primary, 26 May 2003, F. Pupulin 4767 R. Dressler, K. Dressler, J. 
VOL. 26, NO. 1
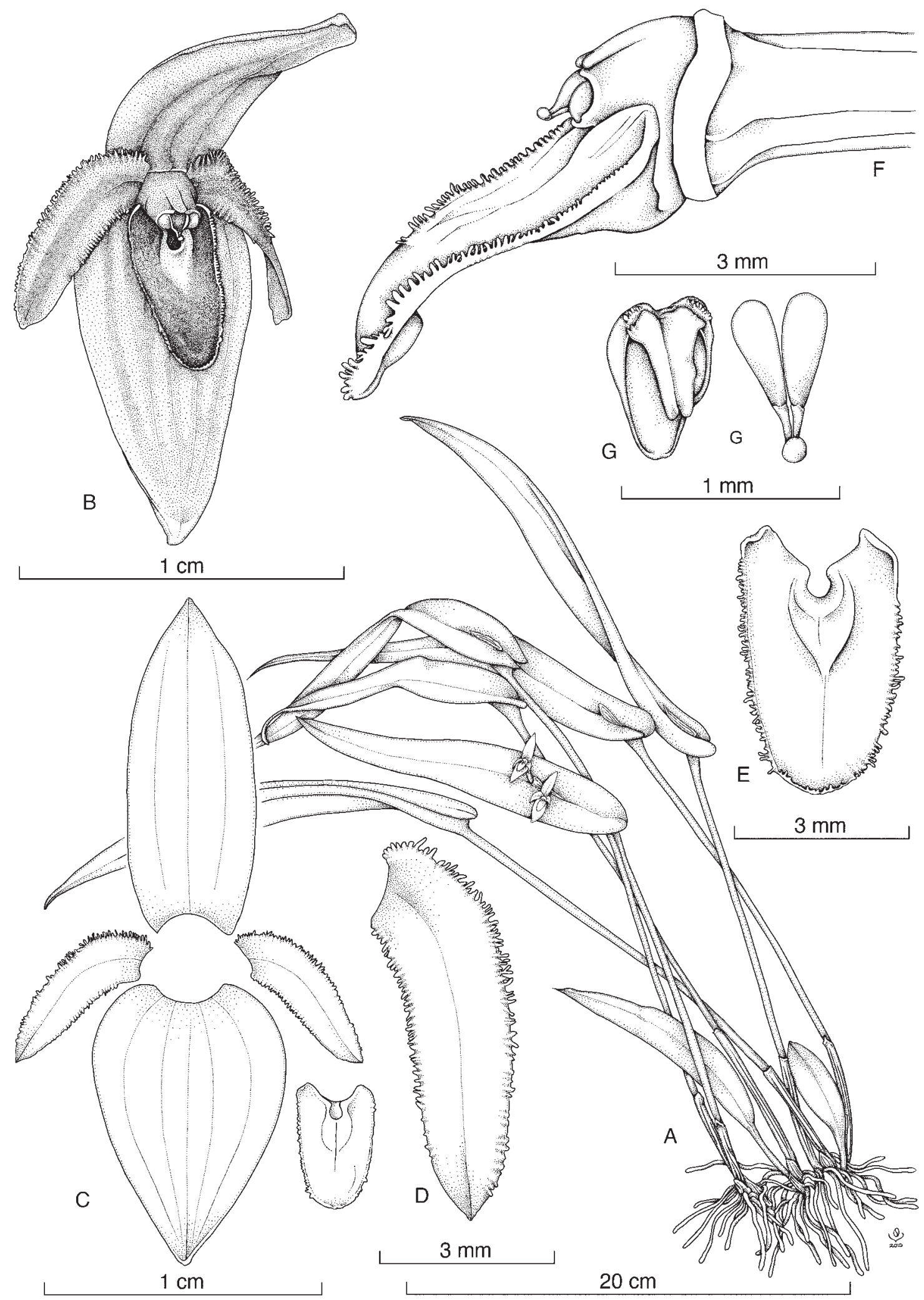

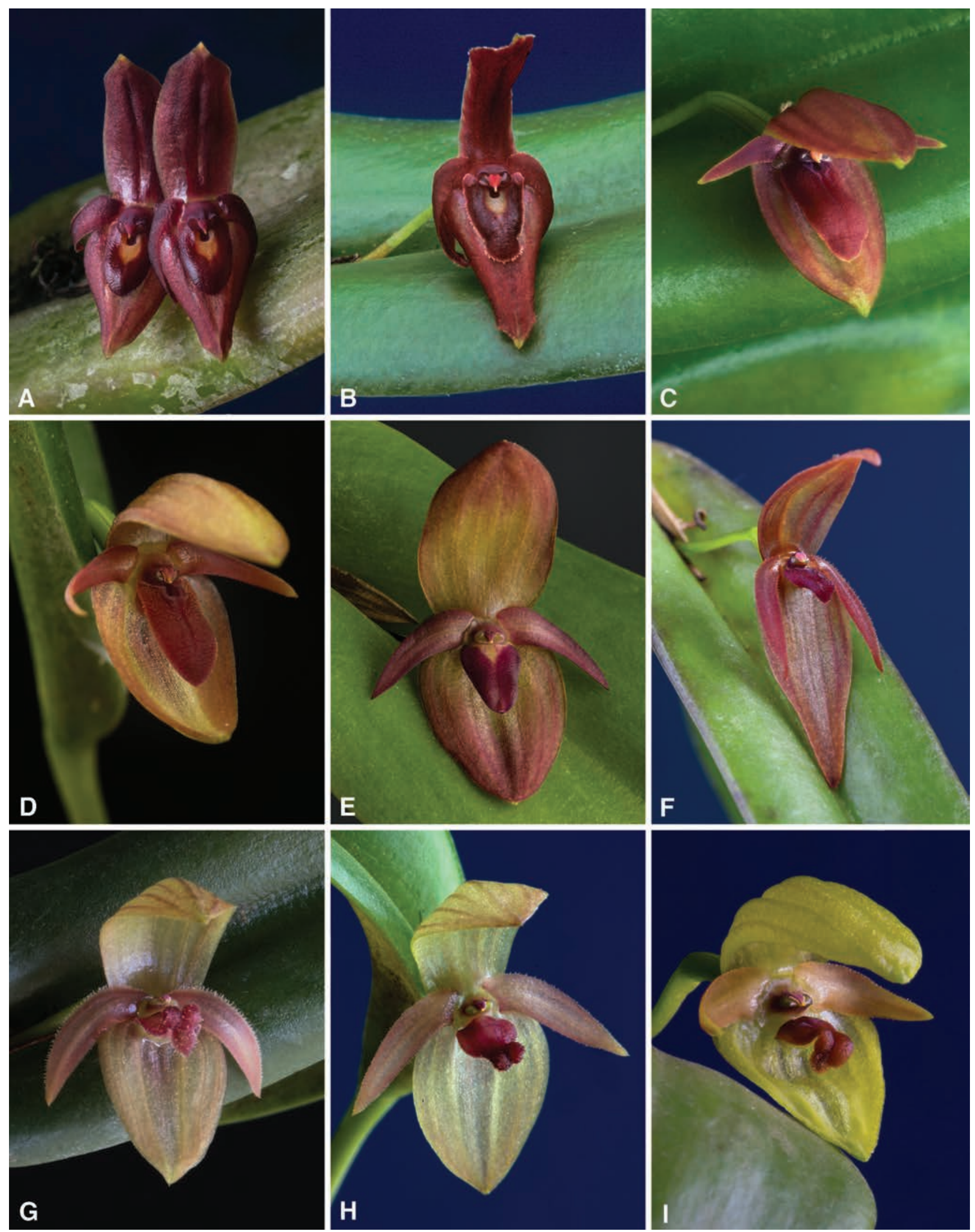

Figure 10. Flowers of Pleurothallis species from Costa Rica in the P. tonduzii group. A-B, P. angusta (Bogarín 8863; Pupulin 1350); C-D, P. grandilingua (Bogarín 5638; Bogarín 8358); E, P. xkarremansiana (Díaz 270); F, P. xparentis-certa (Bogarín 11802); G-I, P. tonduzii (Serrano154; Karremans 4575; Karremans 5840). Not at the same scale. All the vouchers at JBL. Photographs by F. Pupulin (A-E, G-I) and D. Bogarín (F). 
Aguilar, G. Gerlach, P. Kindlmann, H. León-Paéz, S. PughJones \& E. Serrano (JBL). Limón: Talamanca, Bratsi, en el Valle del Silencio, Atlantic slope, Valle de Silencio, area just $\mathrm{N}$ of Cerro Hoffman, $41 / 2$ airline $\mathrm{km} \mathrm{W}$ of the Costa Rica-Panama, 9.1333333, -82.9666667, 2300-2450 m, 24 Jun 2003, E. Alfaro 4683, R. Delgado \& M. Alfaro (CR). Talamanca, Bratsi, P.N. La Amistad, Atlantic slope, Valle de Silencio, area just N of Cerro Hoffman, 4 1/2 airline $\mathrm{km} \mathrm{W}$ of the Costa Rica-Panama, 1333333, -82.9666667, 2300-2450 m, 24 Jun 2003, E. Alfaro 4683, R. Delgado \& M. Alfaro (CR). Talamanca, Bratsi, P.N. La Amistad Caribe, Reserva Indigena Bribri, $1.7 \mathrm{~km}$ de Alto Lari. In primary forest with heavy epiphyte density, 9.3958333, -83.0944444, 1500-1530 m, 27 Feb 1992, H. Schmidt 627 (CR). Talamanca, Bratsi, R.I. Talamanca Caribe, Amubri, Alto Lari, Kivut, 9.4041667, -83.0875000, 1300 m, 7 Mar 1992, G. Herrera 5199 (CR). Talamanca, Bratsi, Area protegida: R.I. Talamanca Caribe, Amubri, Alto Lari, siguiendo la fila entre los Ríos Dapari y Lari, 9.4041667, -83.0819444, 1300 m, 19 Jun 2007, G. Herrera 5099 (CR). Without specific locality: flowered in cultivation at Jardín Botánico Lankester, 23 Feb 1999, F. Pupulin 1350 (JBL); flowered in cultivation at Jardín Botánico Lankester, 3 Dec 2005, F. Pupulin s.n. (JBL-photo). In cultivation at Las Concavas, probably native of Cachí, C. H. Lankester 850 (AMES). Map 1.

2.Pleurothallis grandilingua Pupulin, M. Díaz \& Pridgeon, Vanishing Beauty. Vol. 2: 851-853. 2020. TYPE: Costa Rica. Costa Rica. San José: Tarrazú, San Lorenzo, ca. 4 km southeast of Santa Marta, road to Bajo Reyes, 9³6'38.2"N, $84^{\circ} 00^{\prime} 52.1^{\prime \prime} \mathrm{W}, 1475 \mathrm{~m}$, wet premontane forest, epiphytic on pastures' fences on the roadside, 20 November 2008, flowered in cultivation at Lankester Botanical Garden, 22 Jul 2016, D. Bogarín 5638, R. L. Dressler, M. Fernández, $R$. Gómez \& R. Trejos (Holotype: JBL). Fig. 11 (Voucher, Bogarin 5638, JBL).

Epiphytic, tall, caespitose herb, to $30 \mathrm{~cm}$ tall. Roots slender, flexuous, ca. $1.5 \mathrm{~mm}$ in diam. Ramicauls $11-18 \mathrm{~cm}$ long, enclosed by 1-3 tubular, obtuse, tightly adpressed, papyraceous, brown sheaths, the first one basal, ca. $2 \mathrm{~cm}$ long, the second inserted in the lower third of the ramicaul, 4-5 cm long. Leaves coriaceous, dark green, paler on the underside, narrowly lanceolate, acute to subacuminate, 9-12 $\times 2-3 \mathrm{~cm}$, rounded at the conduplicate base, the midvein protruding abaxially into a rounded keel, slightly decurring on the stem. Inflorescence a single flower, exerted from a narrow triangular, acute, brown, papery, prostrate spathaceous bract $1.5 \mathrm{~cm}$ long; peduncle filiform, ca. $2 \mathrm{~cm}$ long. Floral bract triangular-ovate, subacute, glumaceous, to $2 \mathrm{~mm}$ long. Pedicel terete, $2 \mathrm{~cm}$ long. Ovary teretesubclavate, rounded, stout, ca. $2 \mathrm{~cm}$ long. Flowers not completely spreading, with the sepals purple-red on a yellowish ground, paler between veins, the apex green, the petals purple, marked with green along the margins, the lip concolorous purple, the column dark purple, the anther pink. Dorsal sepal elliptic, acute, with a rounded apicule, 13 $\times 8 \mathrm{~mm}, 5$-veined. Lateral sepals fused into an ovate, acute, rounded-apiculate, 5-veined synsepal, $12 \times 9 \mathrm{~mm}$, yellowhyaline at the base. Petals narrowly lanceolate-ligulate, subacuminate, 7-8 $\times 2 \mathrm{~mm}$, irregularly denticulate-erose along the margins, the base thickened into a pad-like callus. Lip three-lobed, subrectangular-subpandurate, convex, with a shallow median groove, $7 \times 4 \mathrm{~mm}$, the geniculate base cordiform, the lateral lobes elliptic, minutely erose, apically slightly inflated-convex, the midlobe transversely hemielliptic, rounded, ca. $1 \times 2 \mathrm{~mm}$, provided with a minute apicule and a hemispherical, papillose callus underneath. Column short, thick, dorsiventrally flattened-cylindrical, with a median keel toward the apex, $2 \mathrm{~mm}$ long, with the anther apical, bent, and the stigma apical, bilobed. Anther cap ovate, cucullate, 2-celled. Pollinia 2, pyriform, apically attenuate-recurved, on a rounded viscidium. (Fig. 10C-D).

Etymology: from the Latin grande, "large," and lingua, "tongue," in allusion to the large size of the lip in relation to other parts of the flower, uncommon in species of Pleurothallis.

Distribution: known only from Costa Rica.

Ecology: the species is known to inhabit wet premontane and lower montane forests of the Talamanca mountain range, where it is apparently restricted to the Pacific watershed at elevations of 1450-2000 $\mathrm{m}$. The only phenological records show that $P$. grandilingua flowers at least in January and July.

Distinguishing features: Pleurothallis grandilingua is allied to the Costa Rican and western Panamanian endemic $P$. tonduzii Schltr., from which it can be distinguished by the broader leaves, the mostly purple flowers (the sepals greenish yellow to pink, the petals rose in $P$. tonduzii), the narrower synsepal, the ligulate petals (vs. falcate), and the subrectangular, slightly convex lip with the apex extended (vs. sagittate, the apex abruptly bent upward and then strongly geniculate).

Costa Rican material examined: San José: León Cortés, San Pablo, 942'35.87"N, 8401'28.77"W, ca. 2000 $\mathrm{m}$, secondary wood on the old dump of San Pablo de León Cortés, road to the telecommunication towers, legit Daniel Matamoros, flowered in cultivation at Lankester Botanical Garden, 20 January 2011, D. Bogarín 8358 (JBL). León Cortés, San Antonio, ca. $1 \mathrm{~km}$ después de San Antonio camino a San Pablo, ladera noroeste del Cerro Abejonal, $9^{\circ} 42^{\prime} 49.91$ "N, 84' $0.92^{\prime \prime} \mathrm{W}, 1917.8 \mathrm{~m}$, bosque muy húmedo montano bajo, epífitas en bosque secundario, 25 febrero 2020, D. Bogarín 12800, I. Chinchilla \& R. Parra (JBL). Map 1.

3. Pleurothallis $\times$ karremansiana Pupulin, J. Aguilar \& M. Díaz, nothosp. nov.

TYPE: Costa Rica. Alajuela: Zarcero, Palmira, Reserva Biológica Bosque de Paz, creciendo en el jardín de orquídeas, $10^{\circ} 12^{\prime} 15.70 " \mathrm{~N}, 84^{\circ} 19^{\prime} 00.02^{\prime \prime} \mathrm{W}, 1534 \mathrm{~m}$, bosque pluvial montano bajo, 20 agosto 2016, M. Díaz 270, N. Belfort-Oconitrillo \& A. P. Karremans (Holotype: JBL). Fig. 10E, 12, 13 (Voucher, Díaz 270, JBL).

Pleurothallis nothospecie nova inter P. tonduzii Schltr. et P. gonzaleziorum Pupulin, M. Díaz \& Pridgeon, a consimilis 


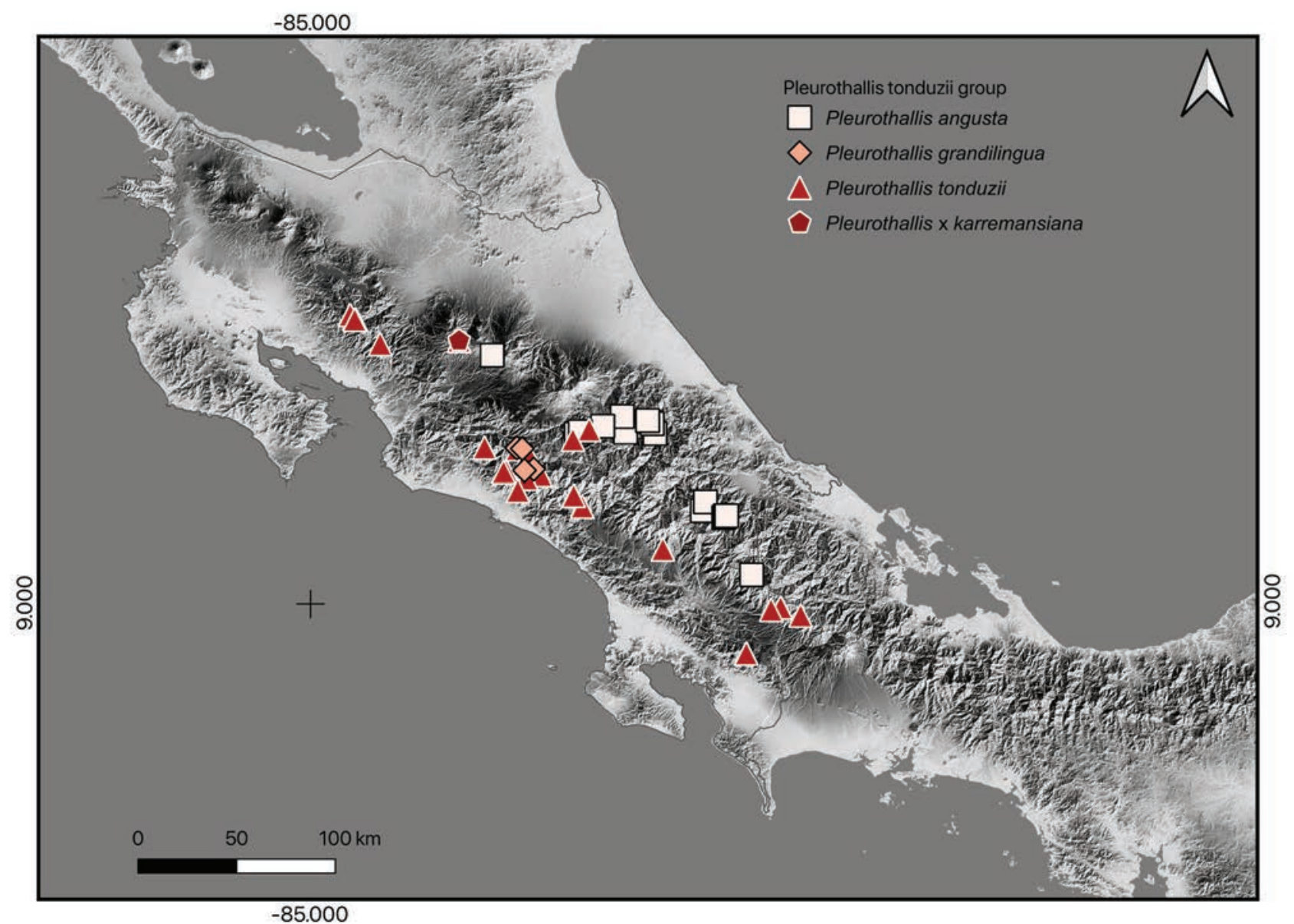

MAP 1. Map of collection sites for the species of Pleurothallis tonduzii group.

foliis cordatis anguste ovatis tenuiter coriaceis, floribus purpureis sepalis late ovatis obtusis vel subacutis, petalis anguste triangulari-subfalcatis acutis, labello pandurato purpureo dignoscenda.

Epiphytic, caespitose, erect to suberect, large herb to $35 \mathrm{~cm}$ tall. Roots slender, flexuous, ca. $1 \mathrm{~mm}$ in diam. Ramicauls terete, slender, 12.5-16.5 cm long, 1.5-2.0 mm in diam., yellowish green, provided with a tubular, truncate sheath to $2.6 \mathrm{~cm}$ long at the base, and a longer, tubular, tightly adpressed, broadly obtuse sheath below the middle, to $5.5 \mathrm{~cm}$ long, the bracts glumaceous, pale green with minute purple warts when young, becoming brown, drypapyraceous with age. Leaf erect, thinly coriaceous, flexible, sessile, narrowly ovate, acuminate, 12.5-16.5 × 3.5-4.2 $\mathrm{cm}$, cordate at the base, grass green, matte. Inflorescence a fascicle of 1-2 flower, usually produced singly, from a prostrate spathaceous bract 1.3-1.6 cm long, brown, drypapyraceous when mature, eventually dissolving with age. Pedicel terete, pale green, 15-17 mm long. Ovary clavate, terete, 7-9 $\mathrm{mm}$ long. Flowers glabrous, sepals and petals pale red becoming dark red toward the margins, lip dark red with yellow glenion, short-lived. Dorsal sepal ovate, obtuse, 12.5-18.5 × 8-13 mm, 7-veined. Lateral sepals connate into a broadly ovate, obtuse to subacute synsepal, 10.5-15.0 $\times 8.5-14.0 \mathrm{~mm}, 7$ - to 8-veined. Petals narrowly triangularsubfalcate, subacute, $7.5-11.0 \times 2.0-2.5 \mathrm{~mm}$, 3-veined. Lip hinged to the column foot, geniculate, pandurate, basally truncate with rounded angles, abruptly acuminate, 6-7 $\times 4-5$ $\mathrm{mm}$, the apical margins thickened; glenion recessed between the basal lobes of the lip, ca. $1.5 \mathrm{~mm}$ long. Column short, transversely subrectangular, dorsiventrally complanate, ca. $2.5 \times 2 \mathrm{~mm}$, the anther apical, bent, the stigma apical, bilobed. Anther cap obtriangular, acute, bilobed at the base, 2-celled, ca. $1.0 \times 0.8 \mathrm{~mm}$. Pollinia 2 , narrowly oblongpyriform, ca. $0.7 \mathrm{~mm}$ long, attached to an elliptic viscidium through a short, cylindric caudicula. Fruit not seen.

Eponymy: named after Adam P. Karremans, a worldrecognized botanist with a strong interest in Pleurothallidinae orchids, who first collected the nothospecies.

Distribution: endemic to Costa Rica.

Ecology: this nothospecies grows as an epiphyte in the premontane and lower montane forests of the Cordillera Volcánica Central, where it is apparently restricted to the Caribbean watershed at elevations of 1400-1600 m. Blooming has been recorded at least from May to December, according to the long-term phenological records of the Orchid Conservation Project at Bosque de Paz Biological Reserve. 
VOL. 26, NO. 1

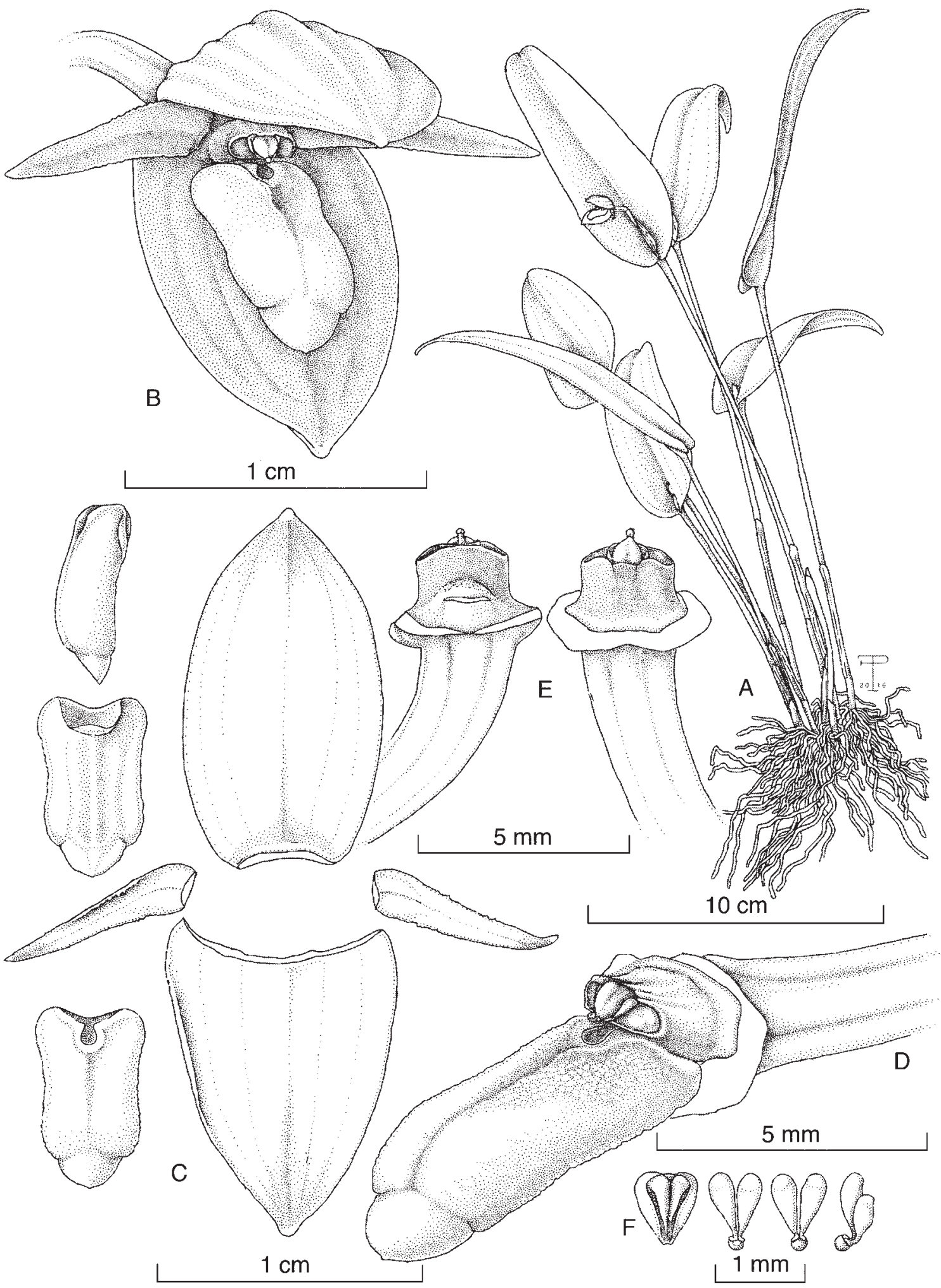

FIgure 11. Pleurothallis grandilingua Pupulin, M. Díaz \& Pridgeon. A, habit; B, flower; C, dissected perianth (the lip in lateral, abaxial, and adaxial views); D, apex of ovary, column, and lip in three-quarter view; E, column, ventral and dorsal views; $\mathbf{F}$, anther cap and pollinarium (three views). Drawn by F. Pupulin and S. Díaz Poltronieri from Bogarín 5638 (JBL). From Pupulin, 2020. 


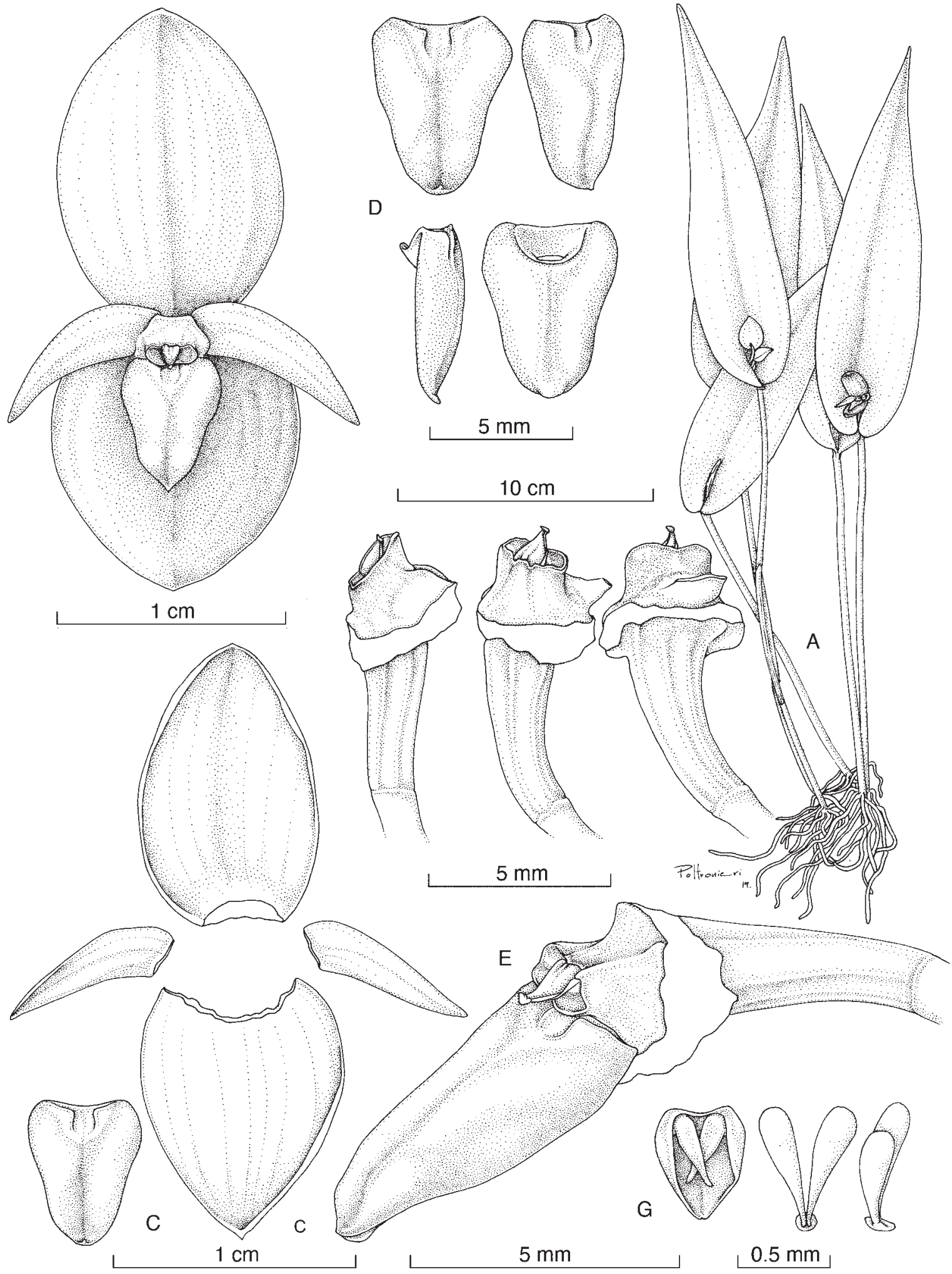

FIguRe 12. Pleurothallis $\times$ karremansiana Pupulin, J. Aguilar \& M. Díaz. A, habit; B, flower; C, dissected perianth; D, lip, in adaxial, three-quarter, lateral, and abaxial views; $\mathbf{E}$, apex of ovary, column, and lip in lateral view; F, column in lateral, dorsal, and ventral views; G, anther cap and pollinarium (two views). Drawn by S. Díaz Poltronieri from Díaz 270 (JBL). 


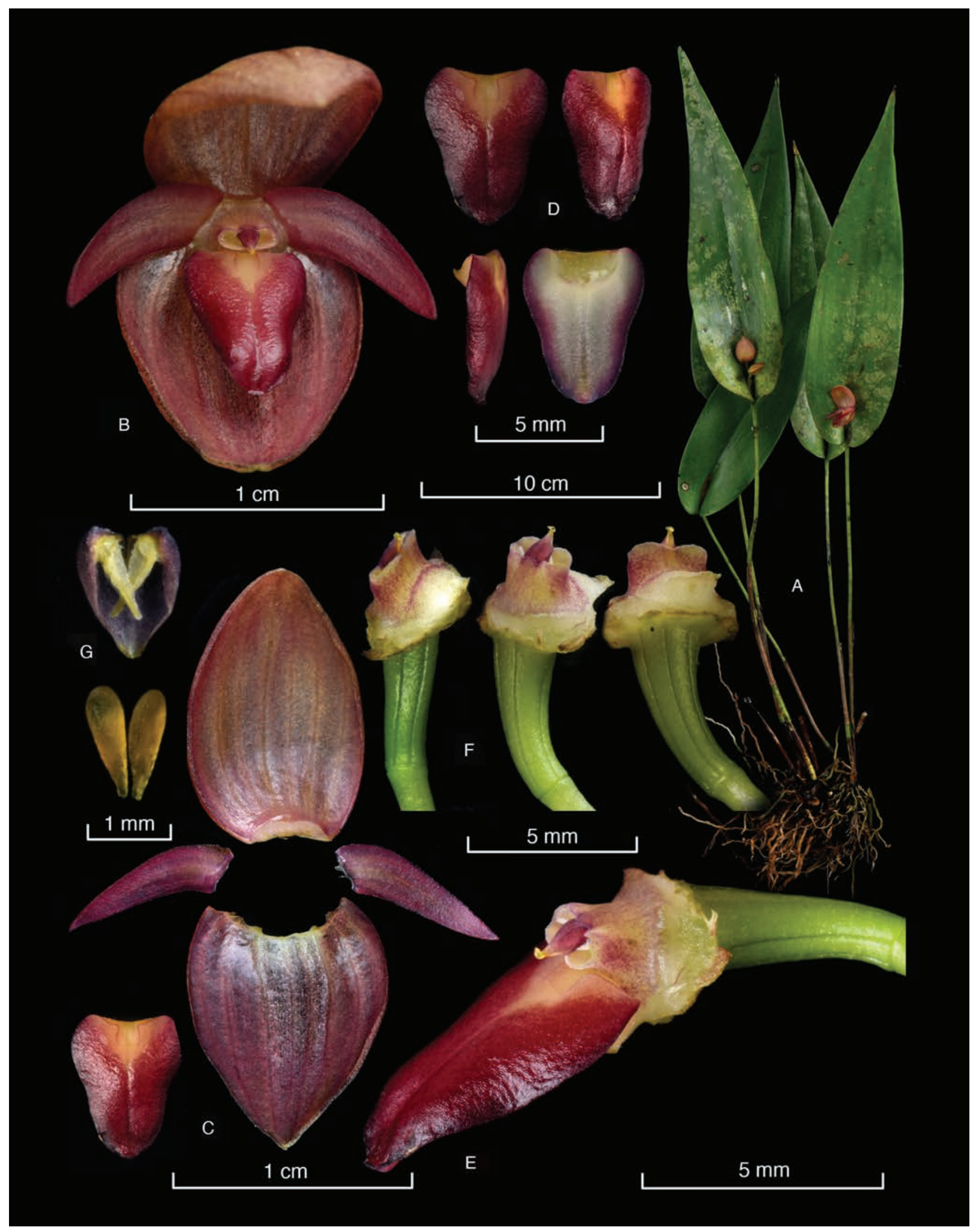

Figure 13. Pleurothallis $\times$ karremansiana Pupulin, J. Aguilar \& M. Díaz. A, habit; B, flower; C, dissected perianth; D, lip, in adaxial, three-quarter, lateral, and abaxial views; E, apex of ovary, column, and lip in lateral view; F, column in lateral, dorsal, and ventral views; G, anther cap and pollinarium (two views). Lankester Composite Dissection Plate prepared by M. Díaz from Díaz 270 (JBL). 
Distinguishing features: the cordate, narrowly ovate, thinly coriaceous, matte leaves and the purple flowers with broadly ovate, arched, inflexed, obtuse to subacute sepals, narrowly triangular-subfalcate, subacute petals, and pandurate lip allow the determination of this natural hybrid.

We interpret the plant that served as the type as a new natural hybrid between Pleurothallis tonduzii and the recently described P. gonzaleziorum (Fig. 14), both species recorded for the orchid flora at Bosque de Paz Reserve, where Adam P. Karremans first noted this nothospecies while it was blooming at the Stephen Kirby Orchid Garden. Vegetatively, it shows long acuminate leaves like those of $P$. tonduzii, which are narrowly ovate, cordate, thinly coriaceous and matte like in $P$. gonzaleziorum (the leaves are distinctly coriaceous in $P$. tonduzii, with the adaxial surface shiny). At bloom, the flower is similar to P. tonduzii in color, its position on the leaf (closer to the base than $P$. gonzaleziorum), and in the arched, kind of inflexed concave sepals (but wider than in P. tonduzii). However, it resembles $P$. gonzaleziorum in the narrowly triangular-subfalcate, subacute petals with entire margin (vs. narrowly linearlanceolate, acuminate, minutely denticulate in P. tonduzii). The lip also shows an interesting combination of features, as it is pandurate and slightly recurved on the apical third like in P. tonduzii, but it is not revolute on the distal half and it is glabrous, with the glenion deeply recessed between the thickened basal lobes of the lip, which makes it look more similar to the lip of P. gonzaleziorum (Fig. 14). Recently, another individual of the nothospecies was found growing in the wild in the forest of the Bosque de Paz Reserve, which allows us to discard the possibility that it represents a garden hybrid.

Costa Rican material examined: Alajuela: Valverde Vega, Bajos del Toro, Reserva Biológica Bosque de Paz, sendero Jaulares, $10^{\circ} 12^{\prime} 19.25^{\prime \prime} \mathrm{N}, 84^{\circ} 18^{\prime} 58^{\prime \prime} \mathrm{W}, 1540 \mathrm{~m}$, bosque premontano en regeneración, ceciendo in situ a una altura de $1.50 \mathrm{~m}, 25$ enero 2020, N. Belfort-Oconitrillo 568, Juan López (JBL, eVoucher). Map 1.

4. Pleurothallis xparentis-certa Pupulin \& Bogarín, nothosp. nov.

TYPE: Costa Rica. Without collecting data, flowered in cultivation with G. Villalobos in San Miguel de Santo Domingo de Heredia, 20 July 2015, D. Bogarín 11802 (Holotype: JBL). Fig. 10F, 15-16 (Voucher, Bogarín 11802, JBL).

Pleurothallis nothospecie nova inter P. tonduzii Schltr. et quemquam speciem Pleurothallidi inflorescen-tibus fasciculatissuccessivis, forsan speciem Pleurothalliditurmaephyllocardiae Luer affinem, intermedia, foliis coriaceis longis anugustibusque, labello sagittato angulis basalis rotundatis figura valde complexeque torta $P$. tonduzii similis, indumento labelli papillato-verrucoso et petalis deflexis alium genitorem reminiscens.

Epiphytic, caespitose, spreading to subpendent herb, up to $25 \mathrm{~cm}$ tall. Roots slender, flexuous, ca. $1 \mathrm{~mm}$ in diam. Ramicauls terete, slender, 6-12 cm long, $1.3-2.0 \mathrm{~mm}$ in diam., greenish brown, with 2 basal, tubular, tightening, obtuse-truncate sheaths, the lowest one much shorter, the upper one to $3.3 \mathrm{~cm}$ long, glumaceous, grayish brown when developing, dry-papyraceous, brown when mature. Leaf borne at the apex of the ramicaul, subpendent to pendent, slightly arched, coriaceous, flexible, sessile, oblong-ligulate, acuminate, $14.0-16.5 \times 1.1-1.3 \mathrm{~cm}$, rounded to subcordate at the base, the basal lobes suberect, not overlapping, the margin flat, dark green. Inflorescence a solitary flower, subtended by a spathaceous, supine, brown, dry-papyraceous, bract ca. $10 \mathrm{~mm}$ long, dissolving with age. Peduncle terete,

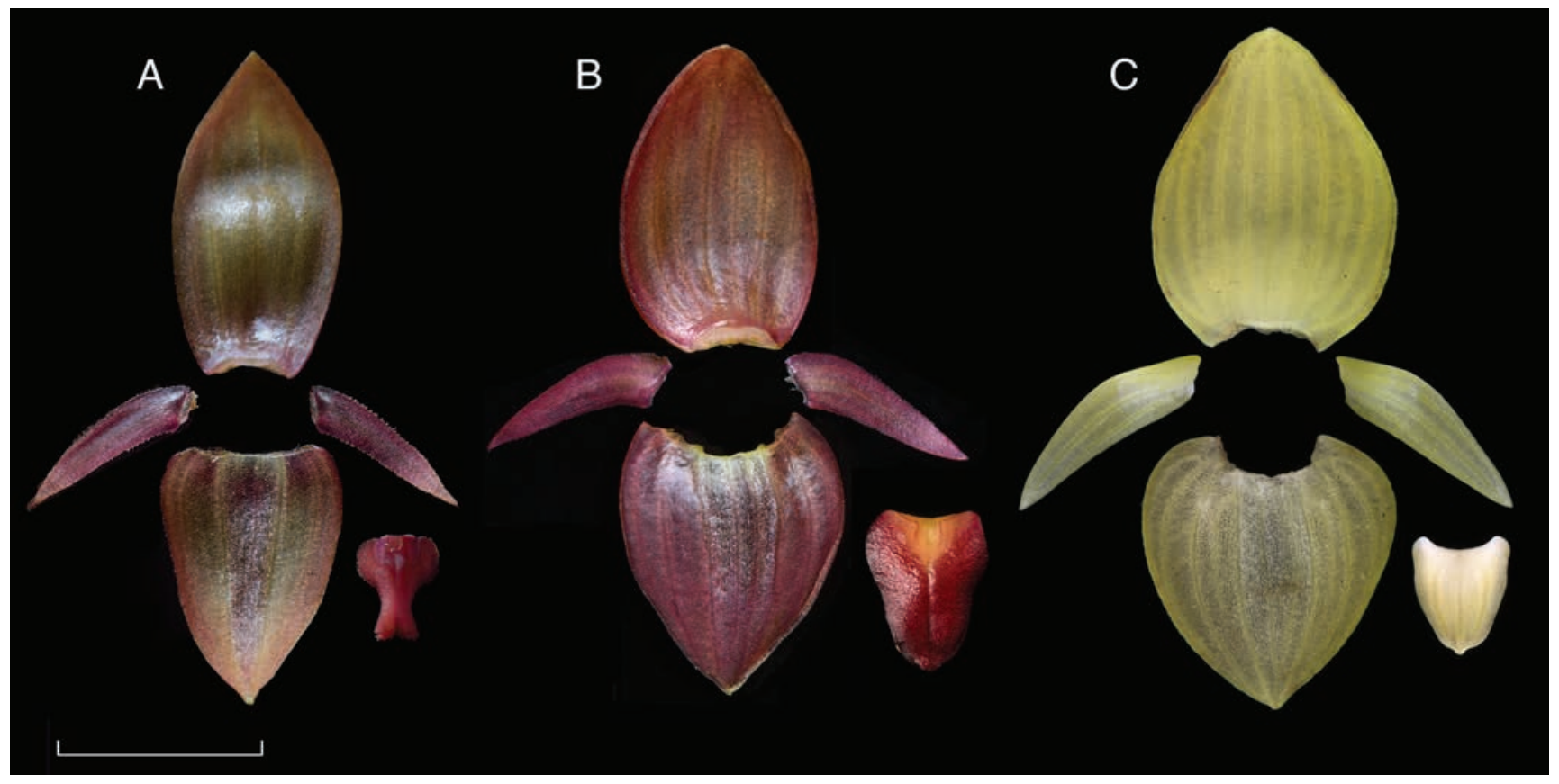

FIgURE 14. Comparison of the perianths of Pleurothallis $\times$ karremansiana and the putative parents. A, P. tonduzii (JBL-02455); B, P. $\times$ karremansiana (Díaz 270); C, P. gonzaleziorum (Díaz 281). Scale bar $=1 \mathrm{~cm}$. All the vouchers at JBL. Photographs by F. Pupulin. 


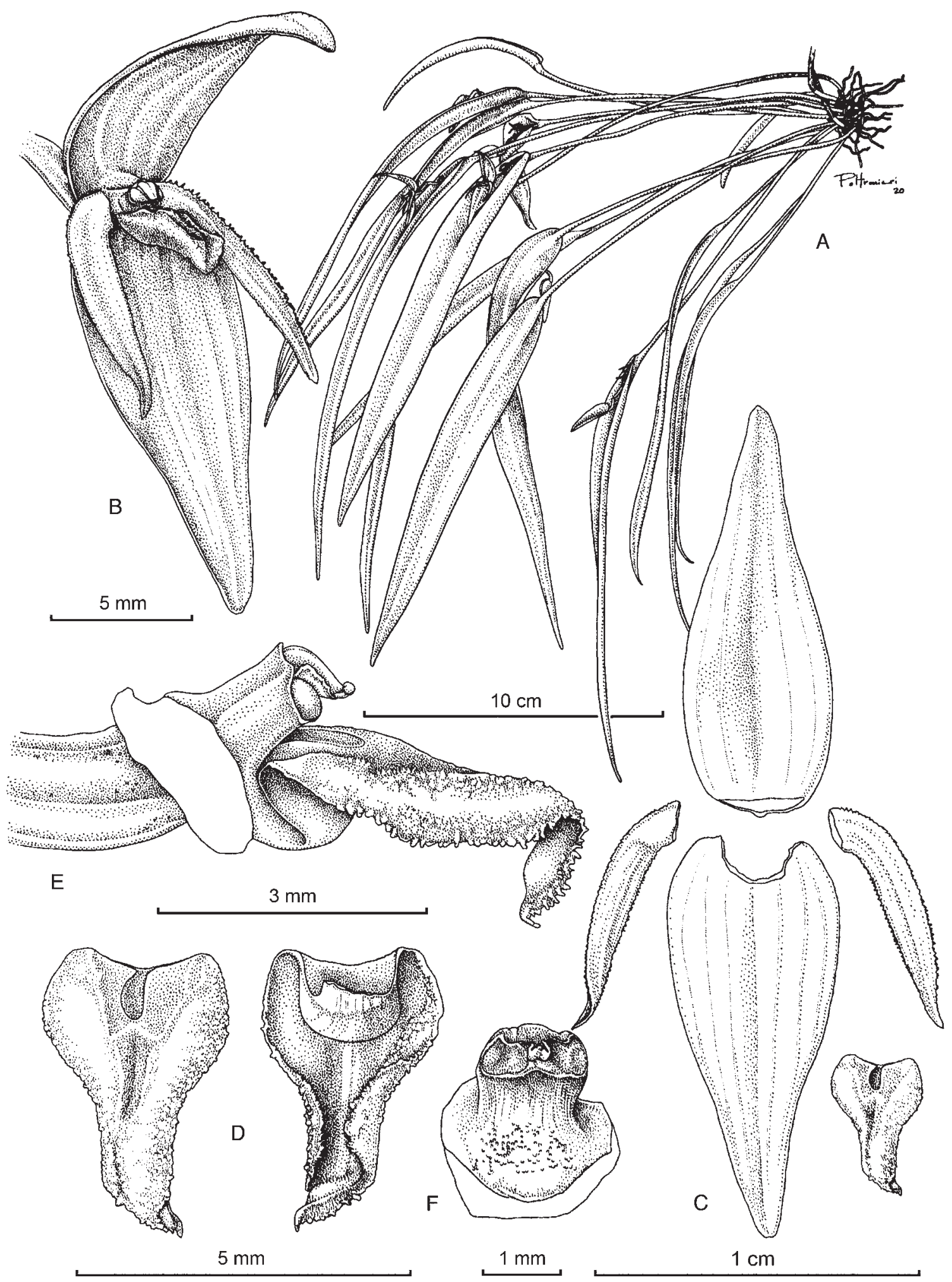

Figure 15. Pleurothallis xparentis-certa Pupulin \& Bogarín. A, habit; B, flower; C, dissected perianth; D, lip, in adaxial and abaxial views; E, apex of ovary, column, and lip in lateral view; F, column, ventral view. Drawn by S. Díaz Poltronieri from Bogarín 11802 (JBL). 


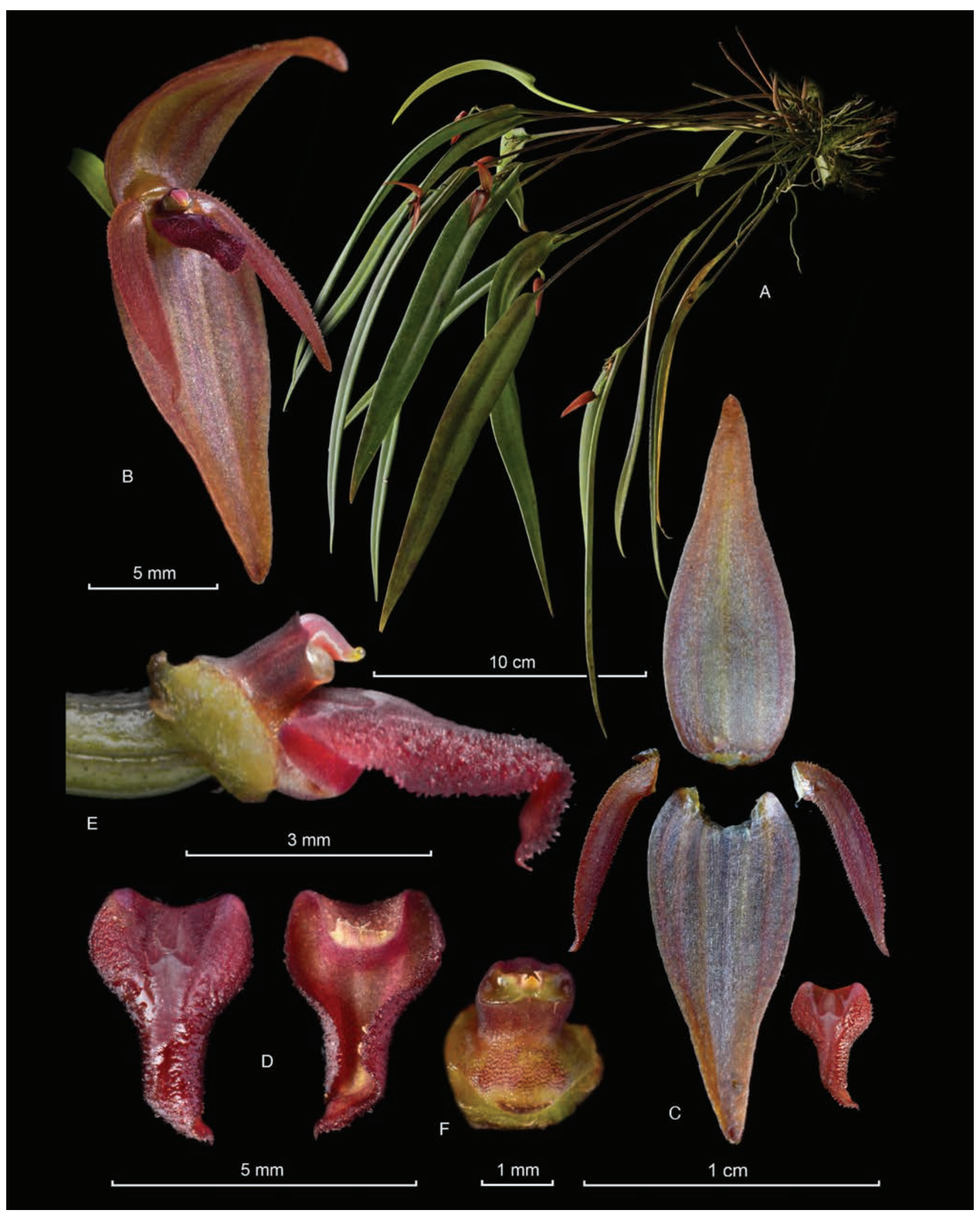

FIgURE 16. Pleurothallis $\times$ parentis-certa Pupulin \& Bogarín. A, habit; B, flower; C, dissected perianth; D, lip, in adaxial and abaxial views; E, apex of ovary, column, and lip in lateral view; F, column, ventral view. Lankester Composite Dissection Plate prepared by D. Bogarín and F. Pupulin from Bogarín 11802 (JBL). 
slender, 10-11 mm long. Pedicel terete, green, $6 \mathrm{~mm}$ long. Ovary terete-subclavate, upcurved, $5.5 \mathrm{~mm}$ long. Flowers spreading-inflexed, the sepals rose-purple with purple stripes, the petals purple red, the lip dark magentapurple, the column purple. Dorsal sepal arched over the column, concave, lanceolate, acuminate, $12.5 \times 4.2 \mathrm{~mm}$, 5 -veined. Lateral sepals connate into a lanceolate, abruptly acuminate, basally concave synsepal, $12 \times 5 \mathrm{~mm}$, each half 3-veined. Petals narrowly linear, falcate, acuminate, minutely serrulate, deflexed, $7.5 \times 1.5 \mathrm{~mm}$, single-veined. Lip unguiculate, hinged to the column foot, thick, fleshy, erect, lanceolate-pandurate, basally truncate-subcordate with rounded angles, abruptly recurved toward the apex, acute, the margins denticulate, revolute on the distal half, $4.0 \times 2.6 \mathrm{~mm}$ when spread, minutely papillous-verrucose throughout; glenion recessed within a conic, glabrous, apical bilobed cavity at the base, $1.2 \mathrm{~mm}$ long. Column short, stout, transversely subrectangular, dorsiventrally complanate, with a thick, densely papillose foot ca. $1 \mathrm{~mm}$ long, $1.4 \times 1.3 \mathrm{~mm}$, the anther apical, the stigma apical, bilobed. Anther cap cucullate, ovate, subtruncate, 2-celled. Pollinia 2, claviform, $1.0 \mathrm{~mm}$ long, attached to a globose viscidium.

Etymology: from the Latin parens, parentis, "a parent," and certus, - $a$, "certain, sure, trusty," in reference to the possibility of determining with certainty only one of the two putative parents of the nothospecies.

Distribution: know only from Costa Rica.

Ecology: nothing is known of the ecology of this putative natural hybrid.

Distinguishing features: the long and narrow, coriaceous leaves and the small rose-purple flowers with lanceolate, acuminate sepals and an erect, highly torsioned magentapurple lip are characteristic of the nothospecies.

We interpret this peculiar finding as a new natural hybrid of Pleurothallis, involving $P$. tonduzii as one of the putative parents. The habit of the plant, with long and narrow, coriaceous, ligulate-oblong leaves and a highly complex three-dimensional lip held almost perpendicularly to the flower and subject to several different torsions both longitudinally and transversally, is unmistakably associated with P.tonduzii, which we postulate to be one of the parents of the new nothospecies. Apart from the shape and orientation of the lip, however, the flowers of P. parentis-certa have only a superficial resemblance to those of $P$. tonduzii as to their dimensions and morphology. Both the dorsal sepal and the synsepal of the nothospecies are lanceolate and subacuminate, while in $P$. tonduzii they are ovate-elliptic and subacute to acute; they are distinctly shorter than in $P$. tonduzii and about half the width. The size of the flower, which is roughly half those of P. tonduzii (Fig. 17), the papillate-verrucose indumentum of the lip, and the falcatepending, denticulate petals, are suggesting a parentage with a species of the Pleurothallis phyllocardia group.

5. Pleurothallis tonduzii Schltr., Beih. Bot. Centralbl., Abt. 2 36(3): 397. 1918. Acronia tonduzii (Schltr.) Luer, Monogr. Syst. Bot. Missouri Bot. Gard. 103: 199, f. 200. 2005. Zosterophyllanthos tonduzii (Schltr.) Szlach. \& Kulak, Richardiana 6(4): 193. 2006. TYPE: Costa Rica. [Alajuela:]
Forêts de San Ramón, 1500-1600 m, May 1913, A. Tonduz s.n. (Herb. Nac. Costa Rica 17646) (Holotype: B, destroyed; Lectotype, designated by Pupulin et al., 2016, tracings of the original drawing of the holotype, made under Schlechter's supervision: AMES 23680/barcode 00074808). Fig. 18-19 (Vouchers, Karremans 5840 and JBL-02455, JBL).

Epiphytic, caespitose, erect herb, up to $35 \mathrm{~cm}$ tall. Roots slender, flexuous, 1-2 $\mathrm{mm}$ in diam. Ramicauls terete, slender, 4-23 cm long, 1.0-2.5 $\mathrm{mm}$ in diam., dark green, with 2-3 basal, tubular, obtuse sheaths, the lowest ones much shorter, $2.5-5.3 \mathrm{~cm}$ long, dry-papyraceous, brown when mature. Leaf borne at the apex of the ramicaul, erect, slightly or notably arched toward the apex, coriaceous, flexible, sessile, narrowly elliptic, acute, becoming sometimes uncinate toward the apex, 5.0-16.0 × 1.3-3.2 $\mathrm{cm}$, obtuse to cordate at the base, the basal lobes inflexed to suberect, not overlapping, the margin flat, dark green. Inflorescence a successive, solitary flower, subtended by a spathaceous bract ca. $1 \mathrm{~mm}$ long, green, becoming brown, dry-papyraceous when mature. Pedicel terete, green, $13 \mathrm{~mm}$ long. Ovary terete, curved, $7 \mathrm{~mm}$ long. Flowers spreading-inflexed, the sepals yellowish green or yellow stained light purple, usually adaxially brownish and abaxially vinous along veins, the petals yellowish green or vinous, the lip dark fuchsia, lustrous, the column light to bright fuchsia. Dorsal sepal arched, concave, ovate, acute, $12.3-15.5 \times 7.2-8.2 \mathrm{~mm}$, abaxially sulcate, the margins inflexed, 7-veined. Lateral sepals connate into an ovate, acute synsepal, the margins inflexed, 10.3-12.5 × 8.8-9.0 $\mathrm{mm}$, each half 4-veined. Petals narrowly linear-lanceolate, acuminate, minutely denticulate, apically somewhat inflexed at maturity, 7.5-9.0 × 2.1-2.5 mm, single-veined. Lip unguiculate, hinged to the column foot, thick, fleshy, almost porrect, pandurate, basally truncate-subcordate with rounded angles, abruptly recurved on the apical third, subacute, the sides denticulate, revolute on the distal half, when spread out 6.4-7.0 ×3.9-4.8 mm, minutely verrucose; glenion raised on a minute, dull callus on the disc, $0.5-0.7$ $\mathrm{mm}$ long. Column short, stout, transversely subrectangular, dorsiventrally complanate, with a thick foot $1.2-1.5 \mathrm{~mm}$ long, 1.3-2.3 × 1.0-2.2 $\mathrm{mm}$, the anther apical, the stigma apical, bilobed. Anther cap cucullate, ovate, subtruncate, 2-celled. Pollinia 2, claviform, 1.0-1.4 × 0.35-0.37 mm, attached to a globose viscidium. (Fig. 10G-I).

Eponymy: named after the Swiss botanist Adolphe Tonduz, who discovered the species.

Distribution: endemic to Costa Rica and western Panama.

Ecology: a widespread but uncommon epiphyte of the premontane and low montane forests on both watersheds of the Continental Divide, from 800 to $1800 \mathrm{~m}$ in elevation. Flowering occurs throughout the year, with a peak in the rainy season between May and November.

Distinguishing features: the thick, narrowly lanceolate leaves subequal in length to the stem, often strongly recurved toward the apex, and the subspreading flower with a complicated lip (Fig. 4), which is basally straight and abruptly raised-geniculate apically made this species unmistakable. 


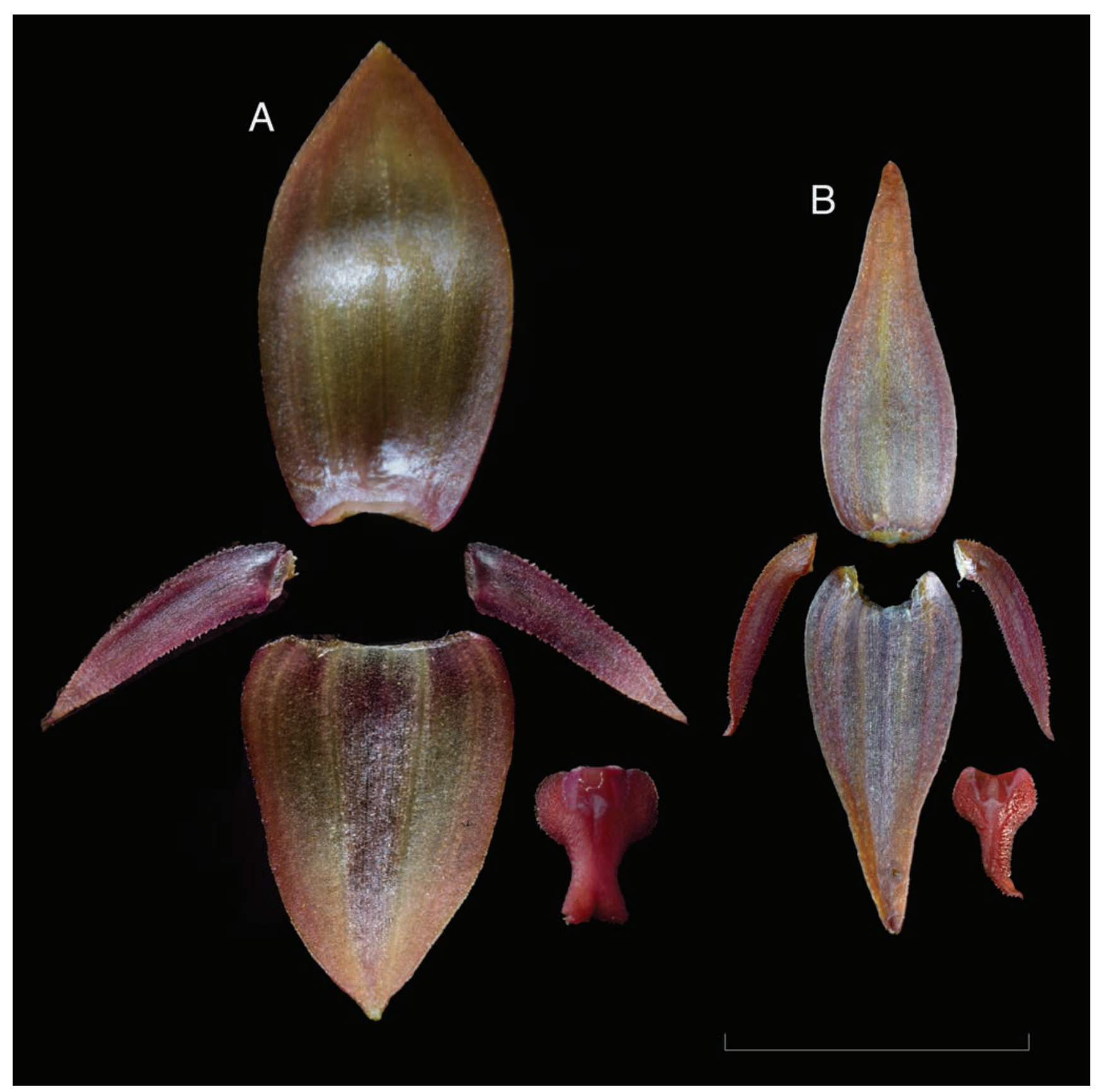

FIgURE 17. Comparison of the perianths of Pleurothallis $\times$ parentis-certa and the putative parent P. tonduzii. A, P. tonduzii (JBL-02455); B, P. xparentis-certa (Bogarín 11802). Scale bar $=1 \mathrm{~cm}$. Vouchers at JBL. Photographs by F. Pupulin.

No actual material of the original collection by Tonduz has been located, and for this reason Pupulin et al. (2016) designated the tracings made in Berlin of the original drawings of the holotype, prepared by Schlechter and made under his supervision, as the species's lectotype. These tracings clearly show the characteristic, tall habit of the plant with narrow, erect leaves, slightly cordate at the base. The sketches of the flower illustrate the denticulate petals and the lip with strongly revolute margins, appearing pandurate in outline, that Schlechter mentioned in the protologue. The same analysis of the flower prepared by Schlechter was posthumously published by Mansfeld (1931: flower analysis no. 44).

Costa Rican material examined: Alajuela: Bajos del Toro, Cataratas, without collector, December 1999, flowered in cultivation at Jardín Botánico Lankester, 11 Jun 2019, JBL-02455 (JBL). Alfaro Ruiz, Palmira, Reserva Biológica Bosque de Paz, orillas del sendero Jaulares, $10^{\circ} 12^{\prime} 17.00^{\prime \prime} \mathrm{N}, 84^{\circ} 19^{\prime} 02.10^{\prime \prime} \mathrm{W}, 1541 \mathrm{~m}$, bosque muy húmedo montano bajo, 11 agosto 2011, A. P. Karremans 4575, D. Bogarín \& M. Muñoz (JBL). Cartago: Paraíso, Orosi, P.N. Tapantí-Macizo de La Muerte, Sendero 


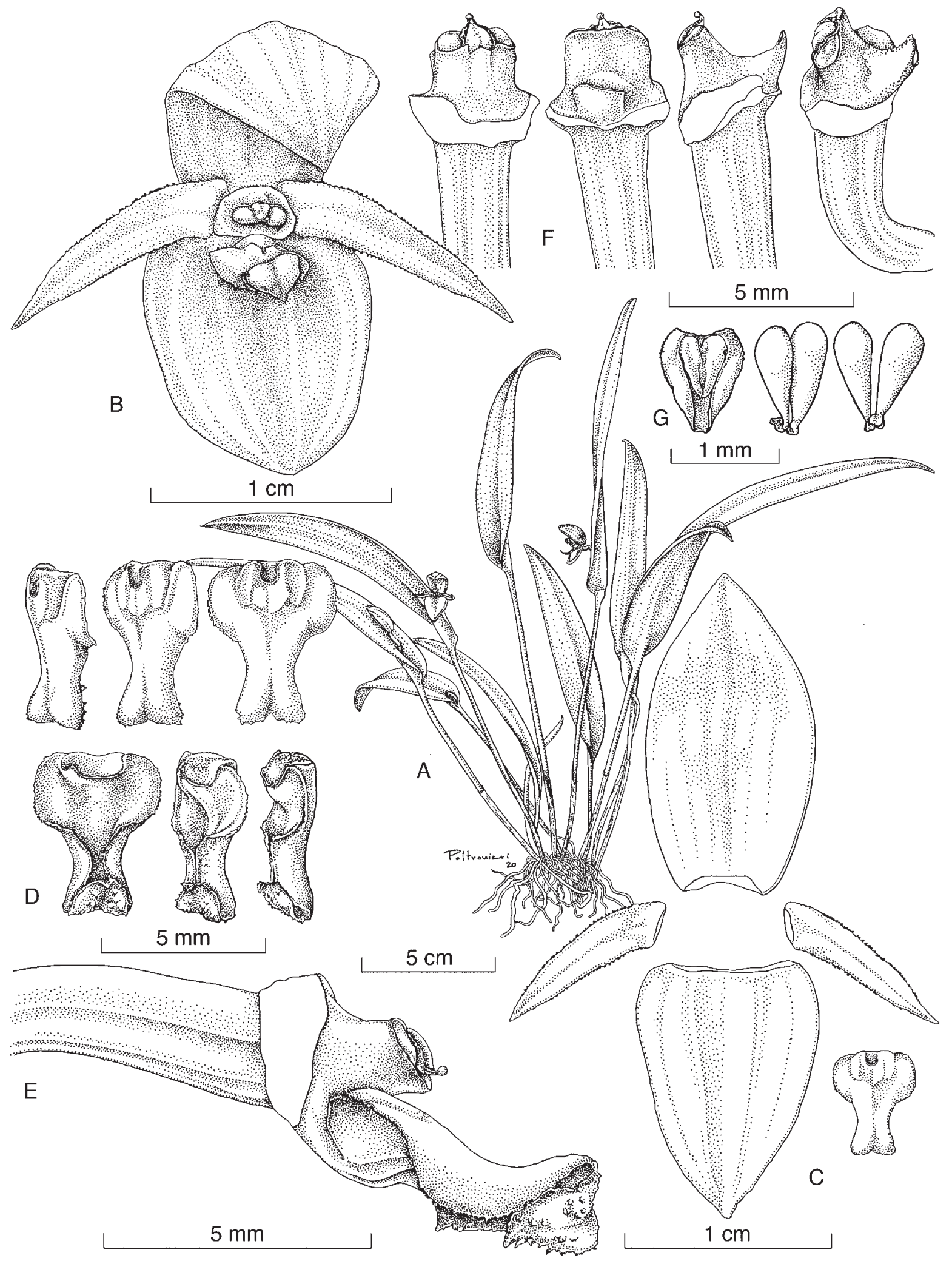

FIGURE 18. Pleurothallis tonduzii Schltr. A, habit; B, flower; C, dissected perianth; D, lip, several views; E, apex of ovary, column, and lip in lateral view; F, column in several views; $\mathbf{G}$, anther cap and pollinarium (two views). Drawn by S. Díaz Poltronieri from $J B L-$ 02455(JBL). 


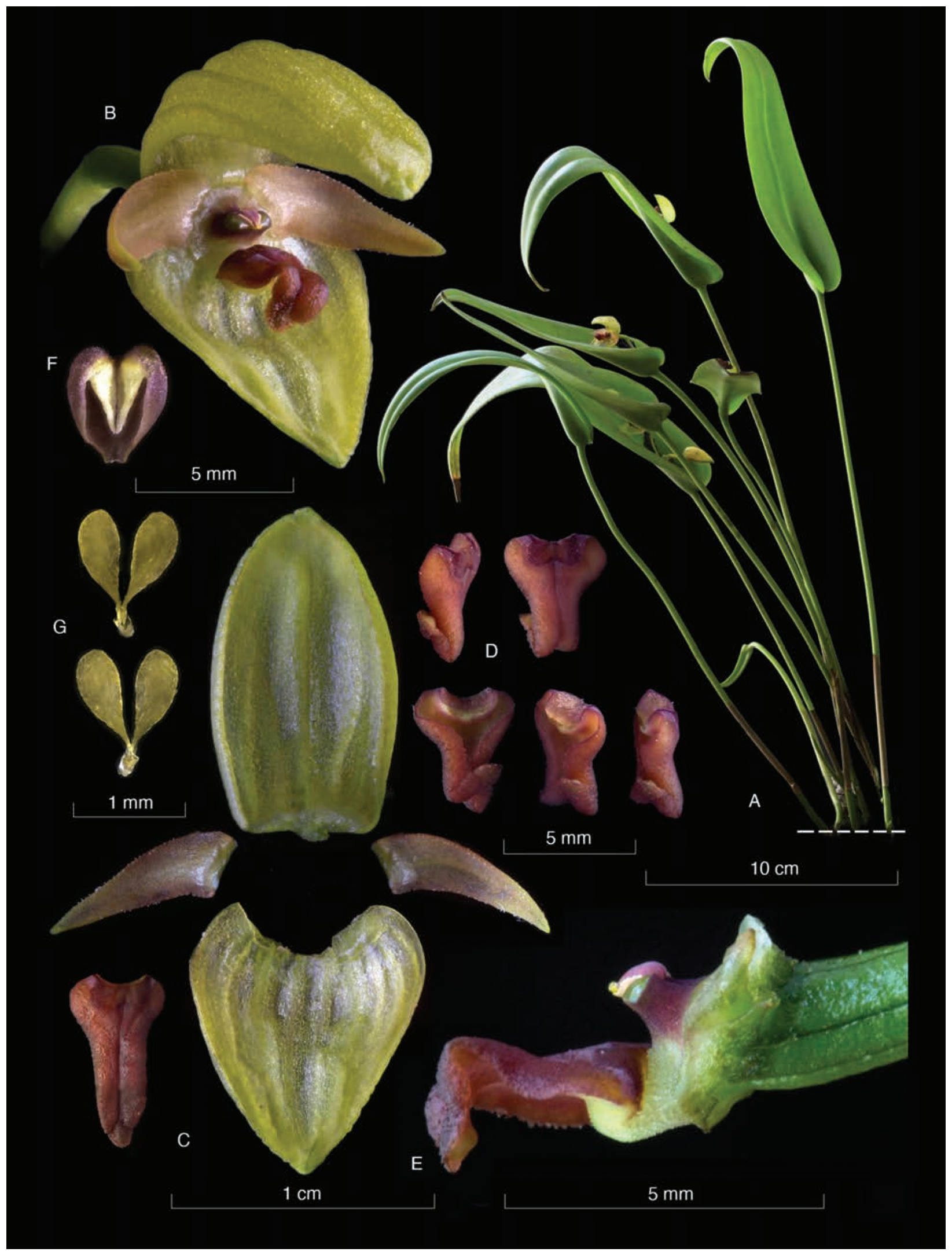

FIGURE 19. Pleurothallis tonduzii Schltr. A, habit; B, flower; C, dissected perianth; D, lip, several views; E, apex of ovary, column, and lip in lateral view; F, anther cap; G, pollinarium (two views). Lankester Composite Dissection Plate prepared by F. Pupulin from Karremans 5840 (JBL). 
Oropendola. Bosque secundario, 9.7516667, -83.7908333, 1300 m, 20 Aug 1992, J. F. Morales Quirós 415 (CR). Puntarenas: Buenos Aires, Buenos Aires, entre Santa Rosa y Convento, orillas de la Quebrada Santa María, afluente del Río Cañas, 9¹5'3.797"N, 83²2'33.968"W, 824 m, bosque muy húmedo premontano epífita en árboles a orillas de la quebrada, 20 marzo 2013, A. Karremans 5840, D. Bogarín, J. Cambronero \& F. Pupulin (JBL). Coto Brus, Las Alturas de Cotón, Fila Cedro, unpaved road to Río Cedro, $8^{\circ} 58^{\prime} 20^{\prime \prime} \mathrm{N}$, $82^{\circ} 52^{\prime} 40^{\prime \prime} \mathrm{W}-8^{\circ} 59^{\prime} 03^{\prime \prime} \mathrm{N}, 82^{\circ} 54^{\prime} 20^{\prime \prime} \mathrm{W}, 1670-1240 \mathrm{~m}$, lower montane moist forest, primary vegetation, 20 March 2003, F. Pupulin 4389, H. Léon-Páez \& A. C. Rodríguez (JBL). Coto Brus, Sabalito, Zona Protectora Las Tablas, $13 \mathrm{~km}$ al noreste de Lucha, Sitio Coto Brus, $8^{\circ} 56^{\prime} 46.1^{\prime \prime} \mathrm{N}, 82^{\circ} 44^{\prime} 30.9^{\prime \prime} \mathrm{W}, 1778$ $\mathrm{m}$, finca "El Capricho" de Miguel Sandí, principalmente en árboles de Quercus en las lomas y potreros al margen del río Sutú, bosque muy húmedo premontano, 6 octubre 2010, M. Fernández 381, R. L. Dressler, D. Bogarín \& F. Pupulin (JBL). Coto Brus, Sabalito, Las Alturas de Cotón, Zona Protectora Las Tablas, Estación Biológica Las Alturas, camino al Cerro Chai, 859'00.9"N, 8250'01.5"W, $1650 \mathrm{~m}$, bosque muy húmedo premontano, en bosque secundario a orillas del camino, 26 Octubre 2005, D. Bogarín 2100, R. L. Dressler, R. Gómez, F. Pupulin, A. y S. Rambelli (JBL). Coto Brus, Limoncito, Fila Cruces, camino al Cerro Paraguas, ca. $10 \mathrm{~km}$ al oeste del Jardín Botánico R. \& C. Wilson sobre el camino a Río Claro de Golfito, 846'22.4"N, 8259'33.1"W, $1367 \mathrm{~m}$, bosque pluvial premontano, epífitas en bosque secundario a orillas del camino, 5 Junio 2010, D. Bogarín 7789, A. Karremans (JBL). Montes de Oro, Unión, camino entre Palmital y Cedral, ca. $1.5 \mathrm{~km}$ al noreste del cruce de Palmital, finca de la familia Elizondo, $10^{\circ} 11^{\prime} 20.80^{\prime \prime} \mathrm{N}$, $84^{\circ} 40^{\prime} 54.15^{\prime \prime} \mathrm{W}, 1376 \mathrm{~m}$, bosque pluvial premontano, epífitas en bosque secundario y potreros, 26 Octubre 2013, D. Bogarín 10434 (JBL). Monteverde, Sendero Tranquilo, $1.5 \mathrm{~km}$ SE of Cerro Amigos. Lower montane wet forest. Disturbed primary forest, 10.3000000, -84.8000067, 1500 m, 5 May 1995, D. Penneys 425 (CR). San José: Acosta, Sabanillas, Hda. Tiquires. Los Ayarales, bosque primario y potreros en la Fila innominada al S. del Río Tiquires, 9.7152778, -84.1986111, 1400 m, 4 Jun 1995, J. F. Morales Quirós 4333 (CR). Dota, San Joaquín, 1 km después de la escuela de San Joaquín yendo hacia Quepos, $09^{\circ} 34^{\prime} 32.88^{\prime \prime} \mathrm{N}$, $84^{\circ} 00^{\prime} 18.06^{\prime \prime} \mathrm{W}$, en árboles esparcidos en potreros, $20 \mathrm{de}$ febrero 2012, A. Karremans 5158 (JBL). León Cortés, San Antonio, Cuenca del Pirrís - Damas. San Pablo de León Cortéz, Cerro Abejonal, 9.7083333, -84.0472222, 12 Oct 2003, J. F. Morales Quirós 10022 (CR). Pérez Zeledón, R.F. Los Santos, Los Angeles, Páramo, 9.4975000, -83.7872222, 7 Mar 2001, A. Quesada Hernández 540 (CR). Tarrazú, San Marcos, Carretera hacia San Carlos de Tarrrazú. Remanentes de Bosque a la orilla de la carretera. Plantas epífitas. 09 36'24"N, 84 05'53"O, 1607 m.s.n.m., 24 Setiembre 2004, E. Serrano 154 (JBL). Tarrazú, San Lorenzo, Faja Costena Quepos. Cerro San Isidro, Falda Sur en el camino hacia Esquipulas, 9.5191667, -84.0450000, 400-600 m, 18 Nov 2010, J. F. Morales Quirós 19291, F. A. González Brenes \& D. Santamaría (CR). Tarrazú, San Carlos, Cerro Cura, camino a San Marcos, Bosque remanente en la orilla de la carretera a San Jerónimo de Tarrazú, 9.6047222, -84.1108333, 21 Sep 2004, S. Lobo Cabezas 736 \& A. F. Rojas Alvarado (CR.). Tarrazú, San Marcos, Cerro San Pedro, 9.6847222, -83.9966667, 28 Sep 2000, S. Lobo Cabezas 209, A. Cascante \& J. Sánchez (CR). Without specific locality data: flowered in cultivation at Jardín Botánico Lankester, 28 Apr 1998, F. Pupulin 548 (JBL); flowered in cultivation at Jardín Botánico Lankester, 31 May 2016, JBL-02428 (JBL); flowered in cultivation at Jardín Botánico Lankester, 21 Nov 2016, JBL-02458 (JBL); flowered in cultivation at Jardín Botánico Lankester, 12 Jun 2019, JBL-02515 (JBL); flowered in cultivation at Jardín Botánico Lankester, 27 May 2016, JBL-04793 (JBL); flowered in cultivation at Jardín Botánico Lankester, 13 June 2016, JBL-04794 (JBL); flowered in cultivation at Jardín Botánico Lankester, 3 Aug 2016, JBL-04795 (JBL); flowered in cultivation at Jardín Botánico Lankester, 8 Jul 2016, JBL-29983 (JBL). Map 1.

\section{B. The Pleurothallis palliolata group}

6. Pleurothallis chavezii Luer, Lindleyana 11(2): 72. 1996. TYPE: Costa Rica: Guanacaste: epiphytic in Parque Nacional Guanacaste, Estación Biológica Volcán Cacao, Estación Pitilla, $10^{\circ} 55^{\prime} 45^{\prime \prime} \mathrm{N}, 85^{\circ} 28^{\prime} 15^{\prime \prime} \mathrm{W}, 1100$ m, 24 October 1990, C. Chávez 438 (Holotype, K; Isotypes: CR, MO). Fig. 20 (Vouchers, C. Chávez 438, R. Joyce s.n.photograph).

Epiphytic, caespitose, erect herb, up to $25 \mathrm{~cm}$ tall. Roots slender, flexuous, $1 \mathrm{~mm}$ in diam. Ramicauls terete, slender, $15-26 \mathrm{~cm}$ long, ca. $3 \mathrm{~mm}$ in diam., pale green, with 2-3 basal, short, tubular, obtuse sheaths, and a longer sheath below the middle to $4.5 \mathrm{~cm}$ long, pale green, glumaceous, aging dry-papyraceous, brown. Leaf borne at the apex of the ramicaul and clasping the stem, suberect to a right angle with the stem, convex, coriaceous, flexible, sessile, ovate, acute, abruptly short-acuminate, medium green, 8.0-12.2 × 4.0$6.5 \mathrm{~cm}$, cordate at the base, the basal lobes not overlapping. Inflorescence fascicle-like, bearing 1-3 flowers, subtended by a spathaceous, ovate, complanate, obliquely truncate bract ca. 11-13 mm long, green, becoming brown, drypapyraceous when mature. Peduncle terete, 1-3 mm long. Pedicel terete, green, 12-15 mm long. Ovary terete, green, round in section, $4 \mathrm{~mm}$ long. Flowers bilabiate, ringent, red, the base of the sepals white, the dorsal sepal yellowish white with red stripes along the vein, the base of the lip white. Dorsal sepal cucullate with the apex bent upward, reclinate over the column, broadly elliptical to ovate when spread, obtuse, much wider than the synsepal, $8.5 \times 6.5$ $\mathrm{mm}, 5$-veined. Lateral sepals connate into an oblong, acute synsepal, the base concave and then convex toward the apex, the apex and margins spreading, $8.5 \times 3 \mathrm{~mm}$, each half 6-veined. Petals narrowly elliptical-oblong, acute, narrowed above the base, with a basal lobule lying adjacent to the column, geniculate at the middle, the margins minutely denticulate, thickened along the midvein, $6.5 \times 1.5 \mathrm{~mm}$, single-veined. Lip lanceolate to narrowly subpandurate, acute, hinged to the column foot, fleshy, basally subtruncate with obtuse angles, the apex acute, $4.25 \times 1.5 \mathrm{~mm}$, narrowed to $0.75 \mathrm{~mm}$ above the base and geniculate with a minute 

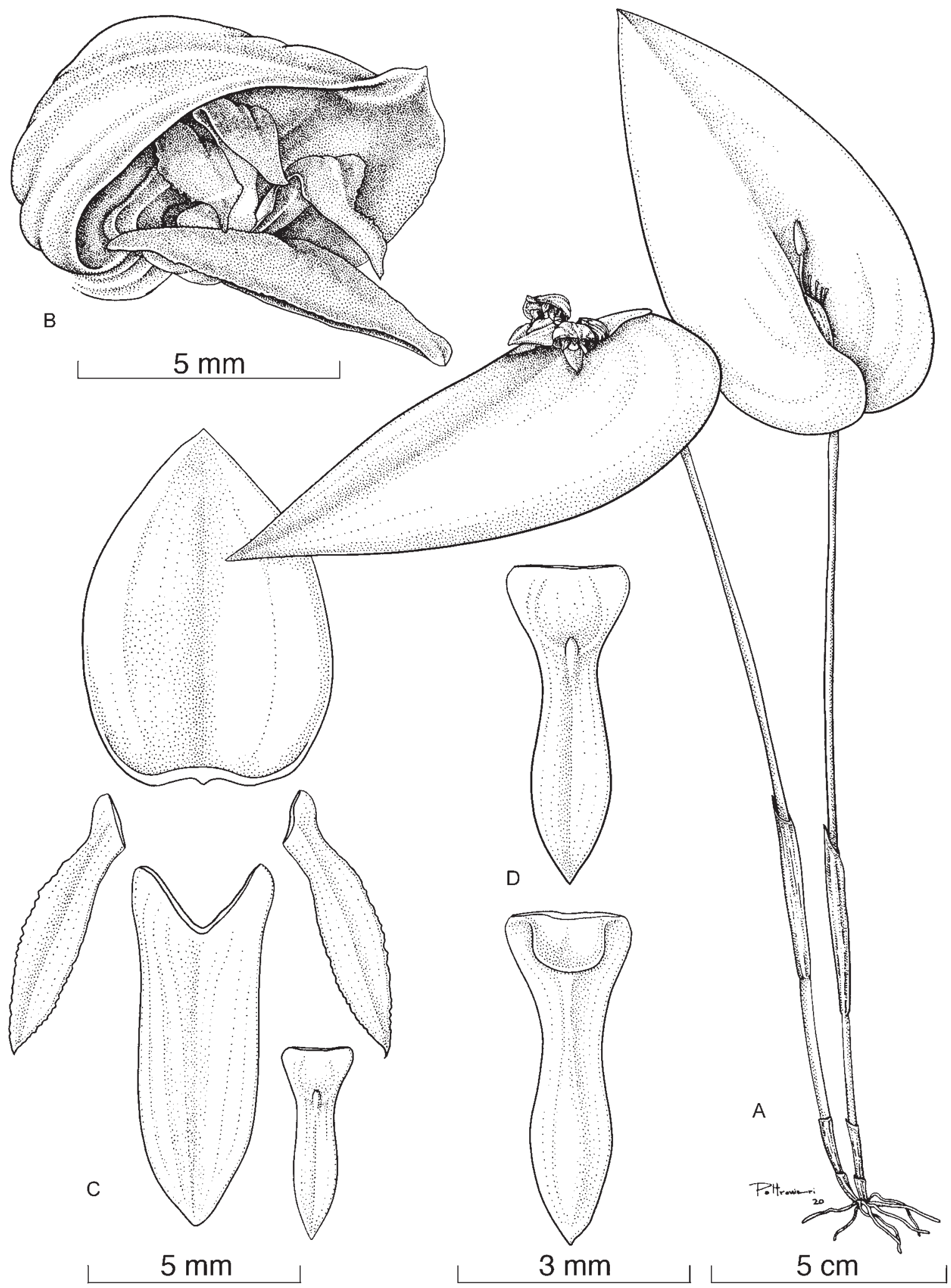

Figure 20. Pleurothallis chavezii Luer. A, habit; B, flower; C, dissected perianth; D, lip, adaxial and lateral views. A-B, drawn by S. Díaz Poltronieri from Joyce s.n. (JBL-photograph); C-D, modified by S. Díaz Poltronieri from Luer (1996) on the basis of Chávez 438 (MO). 
callus on the anterior margin, truncate, with a deflexed claw, the undersurface with a thickening along the midvein greatest above the middle. Column short, stout, transversely subrectangular, dorsiventrally complanate, $1 \mathrm{~mm}$ long, 1.5 $\mathrm{mm}$ wide, with a thick, broad foot ca. $1.5 \mathrm{~mm}$ long, the anther apical, the stigma apical, bilobed. Anther cap and pollinia not seen. (Fig. 21A)

Eponymy: named after Carlos Chávez who discovered this species.

Distribution: known only from Costa Rica.

Ecology: epiphytic in premontane wet forest around 900-1100 m of elevation in the slopes of Volcán Cacao and Volcán Orosí in the Cordillera de Guanacaste, northwestern Costa Rica. Flowering was recorded in January and October.

Distinguishing features: this species is morphologically similar to Pleurothallis maduroi and $P$. palliolata mainly because of the hood-shaped flowers, having the dorsal sepal deeply concave, reclined over the column and much broader than the synsepal. However, $P$. chavezii differs by the red flowers, with a lanceolate-pandurate, geniculate lip and the petals narrowly elliptical-oblong, acute and geniculate. Luer (1996) described this species on the basis of herbarium material. Therefore, the illustration of the type shows the petals and lip flattened. However, in living specimens, the petals and lip are geniculated at its narrowest point, a diagnostic feature of this species.
Costa Rican material examined: Guanacaste: Liberia, Mayorga, P.N. Guanacaste. Estación Biológica Volcán Cacao. Estación Pitilla, 10.9291667, -85.4708333, 24 Oct 1990, C. Chávez 438 \& Curso II de Parataxónomos (CR). La Cruz, Santa Elena, southwestern slopes of Volcán Orosí, east of Sitio Pedregalito, ca. $10^{\circ} 58^{\prime} 18.86^{\prime \prime} \mathrm{N}, 85^{\circ} 28^{\prime} 58.48^{\prime \prime} \mathrm{W}$, ca. $913 \mathrm{~m}$, photographed in situ by Richard Joyce and submitted to the iNaturalist website (https://www.inaturalist. org/taxa/140436-Pleurothallis-chavezii). Map 2.

7. Pleurothallis maduroi Luer, Lindleyana 12(1): 51, f. 12. 1997. Acronia maduroi (Luer) Luer, Monogr. Syst. Bot. Missouri Bot. Gard. 103: 156. 2005. TYPE: Panama. Chiriquí: Guadalupe area, March 1985, A. Maduro 18-M (Holotype: MO). Fig. 21B, 22 (Vouchers, Kaes s.n., JBL; Maduro 18-M, MO).

Epiphytic, caespitose, erect to suberect herb, up to 25 $\mathrm{cm}$ tall. Roots slender, flexuous, $1 \mathrm{~mm}$ in diam. Ramicauls terete, slender, 13-17 cm long, ca. $2 \mathrm{~mm}$ in diam., brownish green, with a basal, tubular, tighten, obtuse sheath 3.5-5.0 $\mathrm{cm}$ long, pale green, glumaceous when developing, aging dry-papyraceous, brown. Leaf borne at the apex of the ramicaul, sessile, erect to curved toward the ramicaul, softcoriaceous to coriaceous, lanceolate to narrowly ovate, acute, abruptly subacuminate, the base deeply cordate, the basal lobes not overlapping, the margins sometimes

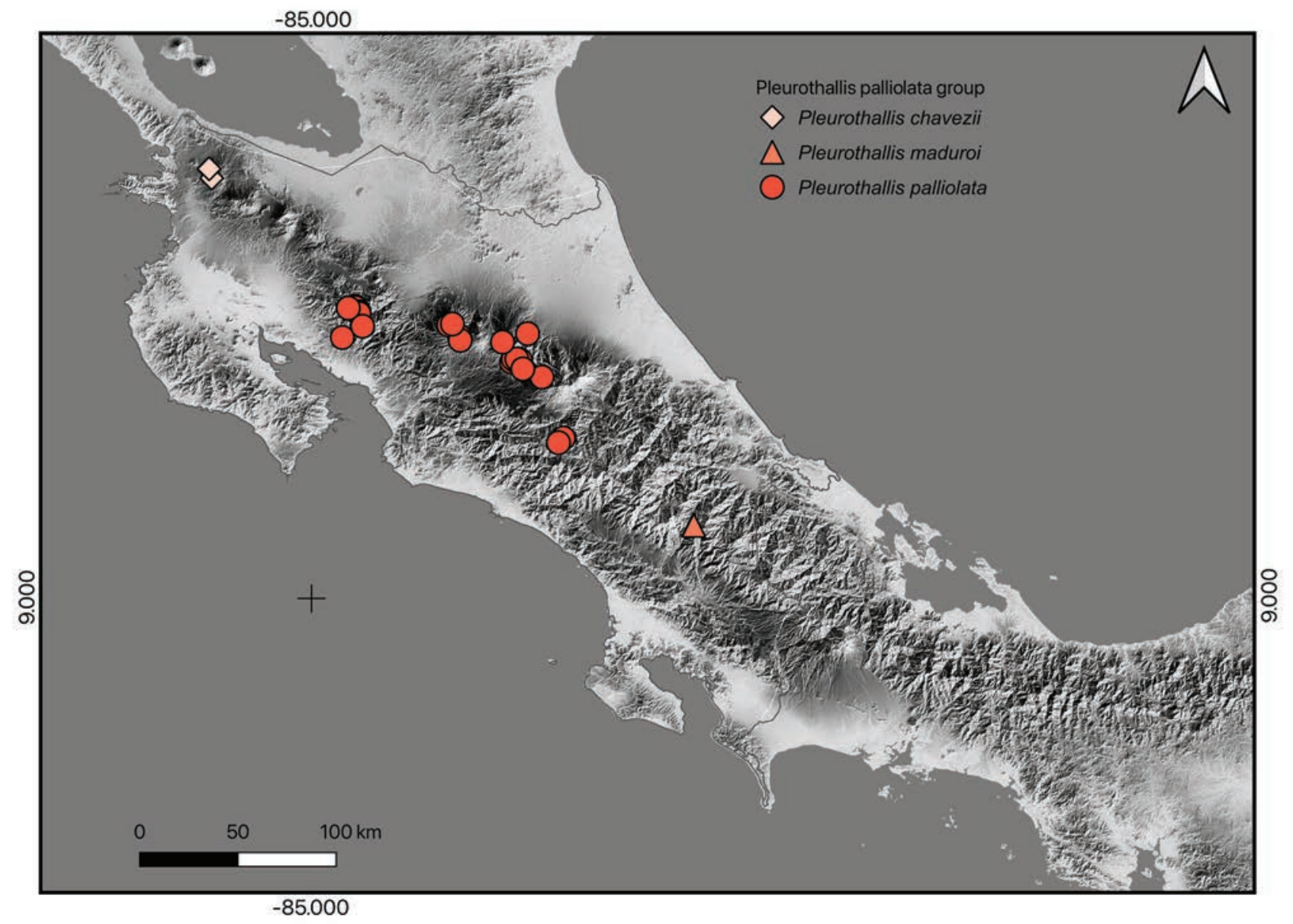

MAP 2. Map of collection sites for the species of Pleurothallis palliolata group. 

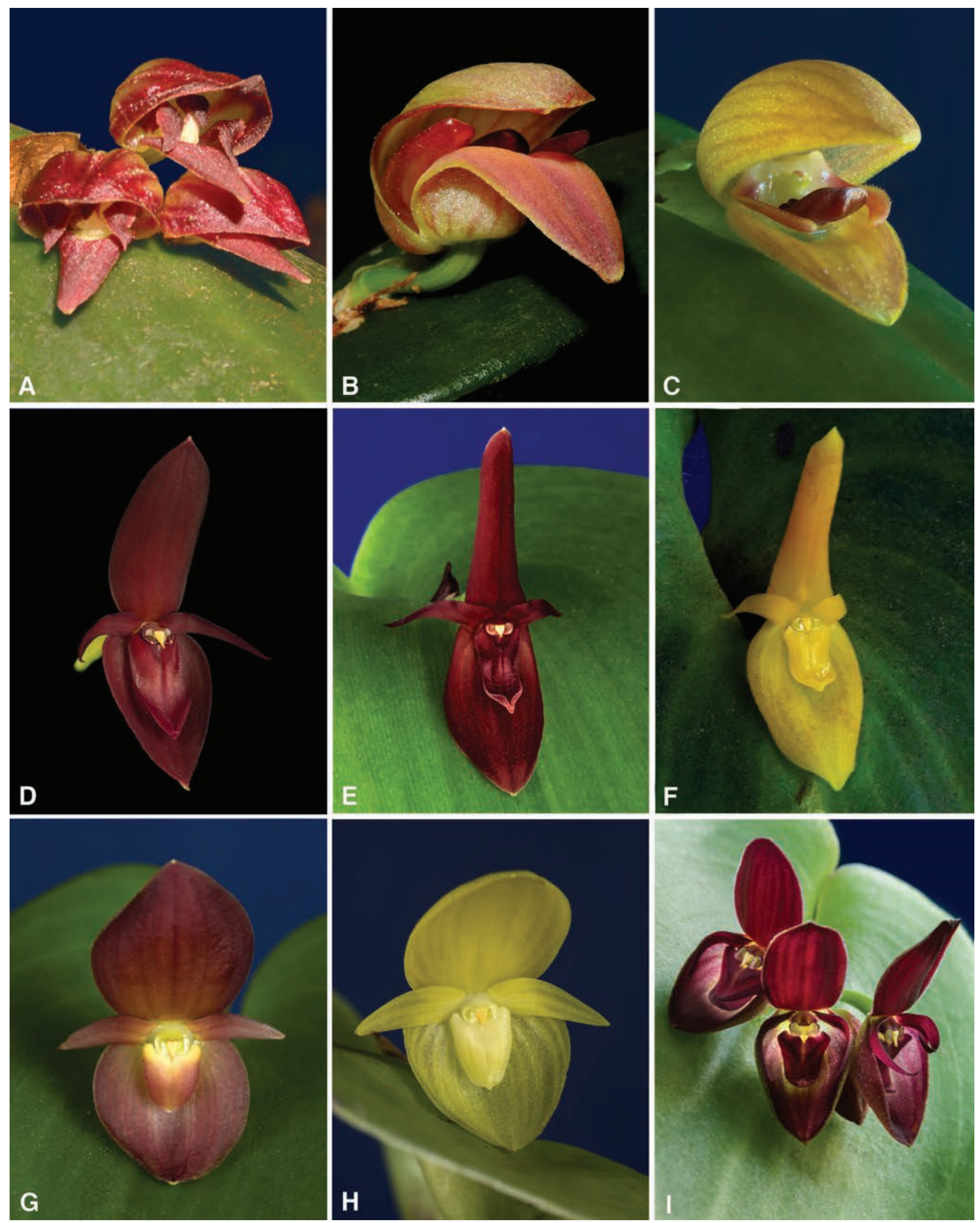

FIgURe 21. Flowers of Pleurothallis species from Costa Rica in the P. palliolata (A-C) and P. cardiothallis (D-I) groups. A, P. chavezii (Joyce s.n.); B, P. maduroi (Kaes s.n.); C, P. palliolata (Bogarín 7303); D, P. callosa (Rojas-Alvarado 258); . E-F, P. cardiothallis (Blanco 2813; Pupulin 6414); G-H, P. gonzaleziorum (Díaz 281; Díaz 269); I, P. navisepala (Pupulin 8846). Not at the same scale. All the vouchers at JBL except A, not conserved. Photographs by F. Pupulin except A (R. Joyce), B (E. Kaes), and D (M. Díaz). 


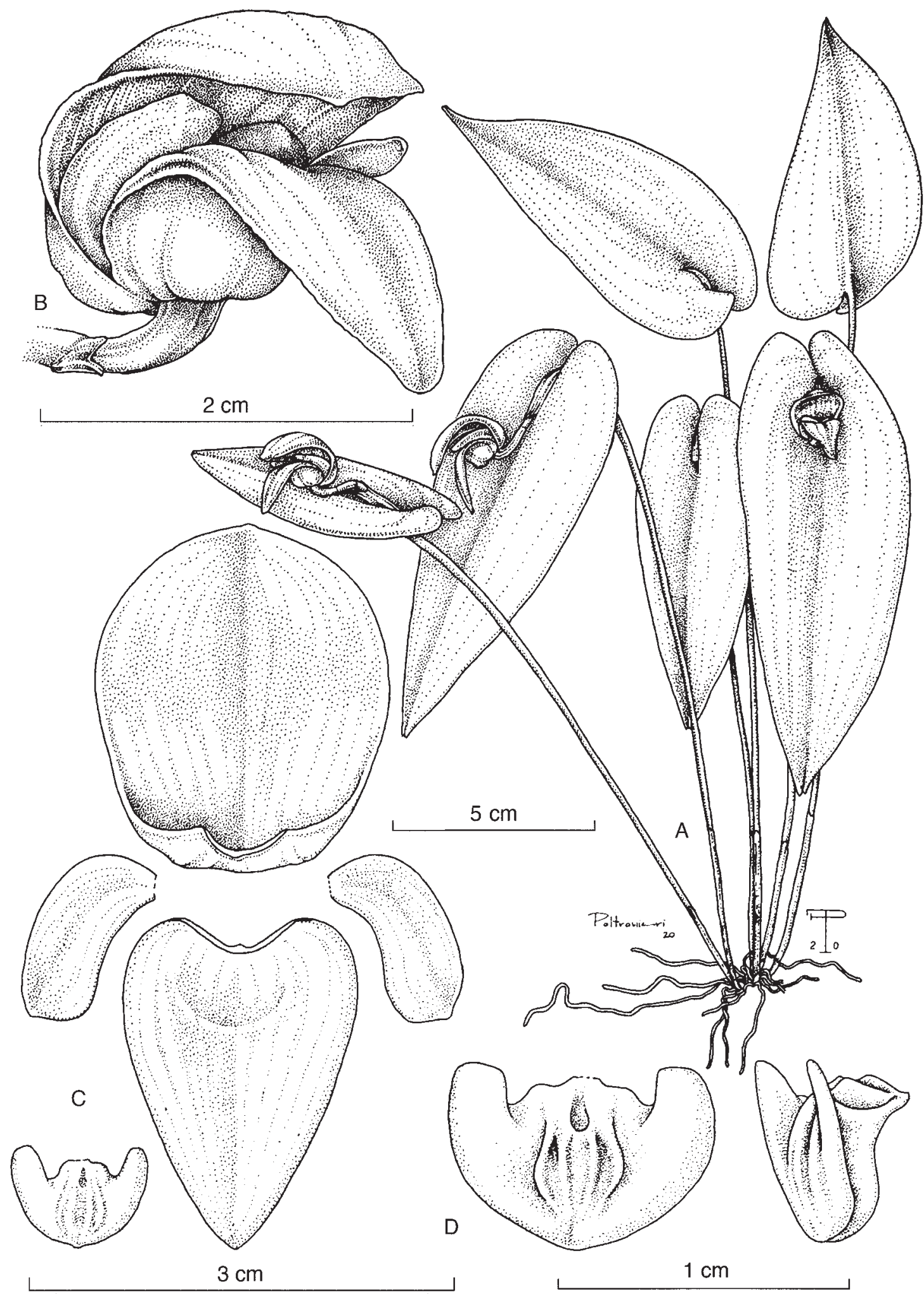

Figure 22. Pleurothallis maduroi Luer. A, habit; B, flower; C, dissected perianth; D, lip, adaxial and lateral views; A-B, drawn by S. Díaz Poltronieri from Kaes s.n. (JBL); C-D, modified by S. Díaz Poltronieri from Luer (1997) on the basis of Maduro 18 (MO). 
undulate toward the base, $6.0-12.2 \times 3.2-5.6 \mathrm{~cm}$, grass green, the adaxial surface shiny. Inflorescence a single flower, subtended by a spathaceous, oblong, complanate, acute bract 11-12 mm long, green, becoming brown, drypapyraceous when mature. Peduncle terete, shorter than the spathe, ca. $10 \mathrm{~mm}$ long. Pedicel terete, green, 5-7 mm long. Ovary terete, sigmoid, green, round in section, $10 \mathrm{~mm}$ long. Flowers bilabiate, ringent, the sepals pale rose-purple on a creamish yellow background, flushed and striped pinkish red toward the apices, the petals red, the lip dark purple, the column white. Dorsal sepal deeply cucullate, almost completely reclinate over the column, broadly obovatesuborbicular when spread, obtuse-rounded, with a rounded apicule, distinctly wider than the synsepal, $2.7 \times 2.3 \mathrm{~cm}$, 17-veined. Lateral sepals connate into a lanceolate, subacute synsepal, the base deeply concave, forming a short chin, the apex and margins spreading, geniculate at the middle, $2.5 \times$ $1.8 \mathrm{~cm}$, each half 6-veined. Petals oblong, falcate, broadly obtuse, decurrent, entire, the thickened apex provided with a short, rounded, adaxial keel, ca. $13 \times 7 \mathrm{~mm}, 5$-veined. Lip unguiculate, hinged to the column foot, fleshy, geniculate at the base, 3-lobed, transversely rheniform-semilunate, basally with 2 lateral, rectangular, rounded-truncate, retrorse lobes, the apex broadly obtuse to subrounded, thick, flat to slightly convex, $6 \times 9 \mathrm{~mm}$, with 4 prominent, thickened veins running from the disc toward the apex and flushing into the blade before the margin, the glenion elliptic, on a low, rounded thickening at the base of the disc, ca. 1.5 $\mathrm{mm}$ long. Column short, stout, transversely subrectangular, dorsiventrally complanate, $1.5 \mathrm{~mm}$ long, with a thick foot, the anther apical, the stigma apical, bilobed. Anther cap and pollinia not seen.

Eponymy: named after Andrés Maduro of Panama City, Panama, who discovered the species.

Distribution: Costa Rica and Panama.

Ecology: terrestrial among organic litter, inhabiting the lower montane wet forest of the Continental Divide in the Cordillera de Talamanca. Flowering has been recorded in the field in November.

Distinguishing features: the large flower with deeply hooded dorsal sepal, distinctly broader than the synsepal and almost completely reclined over the column; the synsepal geniculate at the middle with the distal portion extended; the falcate, oblong petals; and the 3-lobed lip with retrorse auricles are diagnostic of $P$. maduroi.

Costa Rican material examined: Limón: Talamanca, Telire, sendero entre Cerro Arbolado y San José Cabécar, Cerro Casma, entre Quebrada Kuisa y Río Lori, $9^{\circ} 20^{\prime} 11.40 " \mathrm{~N}, 83^{\circ} 13^{\prime} 47.90 " \mathrm{~W}, 2192 \mathrm{~m}$, bosque pluvial montano bajo, terrestre entre hojarasca en bosque primario, 11 noviembre 2016, E. Kaes s.n., M. Acuña \& O. Zúñiga (JBL e-voucher). Map 2.

8. Pleurothallis palliolata Ames, Proc. Biol. Soc. Wash. 35: 86. 1922. Acronia palliolata (Ames) Luer, Monogr. Syst. Bot. Missouri Bot. Gard. 103: 168. 2005.Zosterophyllanthos palliolatus (Ames) Szlach. \& Kulak, Richardiana 6(4): 191. 2006. TYPE: Costa Rica. C. H. Lankester 192/1920
(Holotype: K). Fig. 21C, 23 (Voucher, Bogarín 6106, JBL). Epiphytic, caespitose, erect to suberect herb, up to 15 $\mathrm{cm}$ tall. Roots slender, flexuous, $1 \mathrm{~mm}$ in diam. Ramicauls terete, slender, $10-16 \mathrm{~cm}$ long, ca. $2 \mathrm{~mm}$ in diam., pale green, with 2-3 basal, short, tubular, obtuse sheaths, and a longer sheath below the middle to $4 \mathrm{~cm}$ long, pale green, glumaceous, aging dry-papyraceous, brown. Leaf borne at the apex of the ramicaul and clasping the stem, suberect to a right angle with the stem, coriaceous, flexible, sessile, ovate-lanceolate, acute, abruptly short-acuminate, medium green, sometimes flushed with purple, $7-10 \times 2.8-4.0 \mathrm{~cm}$, cordate at the base, the basal lobes not overlapping; juvenile leaves rounded at the base, the margin flat. Inflorescence a fascicle of 1-3 flowers, subtended by a spathaceous, oblong, complanate, obliquely truncate bract ca. $8 \mathrm{~mm}$ long, green, becoming brown, dry-papyraceous when mature. Peduncle terete, slightly exceeding the spathe, ca. $20 \mathrm{~mm}$ long. Pedicel terete, green, 6-7 mm long. Ovary terete, green, round in section, $5 \mathrm{~mm}$ long. Flowers bilabiate, ringent, the sepals pale yellow, flushed and striped reddish brown to red toward the apices, the petal white, becoming rose-red at apex, the lip dark purple, the column yellowish white. Dorsal sepal cucullate, reclinate over the column, broadly ovate to suborbicular when spread, obtuse, much wider than the synsepal, 1.9-2.0 × $1.8 \mathrm{~cm}, 9-13$-veined. Lateral sepals connate into a triangular-ovate, obtuse to subacute synsepal, the base deeply concave, the apex and margins spreading, 1.3 $\times 1.3 \mathrm{~cm}$, each half 3 -veined. Petals narrowly linear-falcate, acuminate, the base boldly thickened, apically subuncinate, the margins minutely serrate, thickened along the midvein, $7-10 \times 2 \mathrm{~mm}$, single-veined. Lip unguiculate, hinged to the column foot, fleshy, broadly obovate to rounded, basally subtruncate with obtuse angles, the apex rounded, concave, $5 \times 6 \mathrm{~mm}$, with 2 lateral, thickened keels flushing into the middle of the blade, and 2 small, triangular calli at the base. Column short, stout, transversely subrectangular, dorsiventrally complanate, $2 \mathrm{~mm}$ long, with a thick foot ca. $1.5 \mathrm{~mm}$ long, the anther apical, the stigma apical, bilobed. Anther cap cucullate, ovate, subcordate, 2-celled, $1.2 \times$ $0.7 \mathrm{~mm}$. Pollinia 2, claviform, $2.3 \times 0.5 \mathrm{~mm}$, attached to a round viscidium through 2 short, cylindrical caudicles.

Etymology: from the Latin palliolatus, "covered with a cloak-cape or hood" (the palluŏlum was a small Greek mantle), in reference to the hooded dorsal sepal.

Distribution: Costa Rica and Panama.

Ecology: epiphytic, inhabiting the premontane and lower montane wet and cloud forests of the main Costa Rican mountain chains, where it is restricted to the Caribbean watershed at elevations of 1000-2100 m. Flowering has been recorded mostly in October and November.

Distinguishing features: the large flower with the dorsal sepal cucullate, much broader than the synsepal, and the falcate petals apically tinged with red, falcate-uncinate at apex toward the rounded, concave lip easily distinguish $P$. palliolata.

Costa Rican material examined: Alajuela: Carrizal, Concordia, entre Los Cartagos y Cinco Esquinas, $10^{\circ} 08^{\prime} 16.8^{\prime \prime} \mathrm{N}, 84^{\circ} 09^{\prime} 49.8^{\prime \prime} \mathrm{W}, 2027 \mathrm{~m}, 2027 \mathrm{~m}$, bosque 


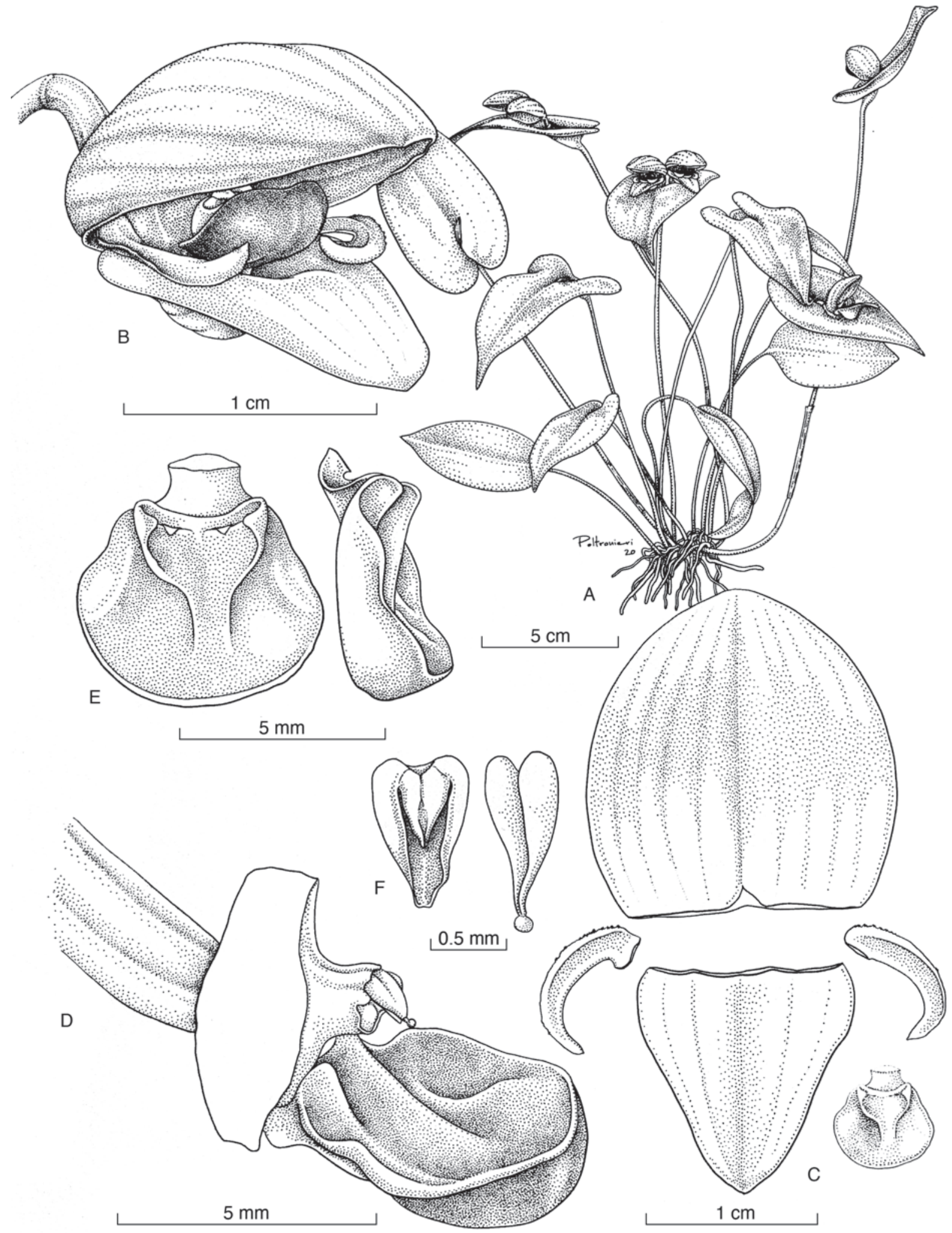

Figure 23. Pleurothallis palliolata Ames. A, habit; B, flower; $\mathbf{C}$, dissected perianth; D, lip in abaxial and lateral views; E, apex of ovary, column, and lip, three-quarter view; F, anther cap and pollinarium. Drawn by S. Díaz Poltronieri from Bogarín 7303 (JBL). 
pluvial montano bajo, en potreros arbolados y bosque secundario, 17 junio 2009, D. Bogarín 7303, R. L. Dressler, F. Pupulin \& R. Trejos (JBL). San Ramón, Peñas Blancas, R.B. Monteverde. Río Caño Negro, Monteverde Cerro Negro y Cabeceras, Río San Gerardo, trail leading to Cerro Amigos, 10.3166667, -84.7833333, 7 Oct 1987, W. Haber 7538 \& E. Bello (CR). San Ramón, Peñas Blancas, Z.P. Arenal-Monteverde (Caribe), Sendero Pantanoso, Valle Torre, 10.3083333 , -84.7833333, 1600-1700 m, 15 Nov 1991, E. Bello 4255 (CR). Cartago: El Guarco, San Isidro, Paso Macho (Macho Gaff), después del puesto de guardaparques del Parque Nacional Tapantí-Macizo de La Muerte, cuenca del Río Macho, camino a Queverí, $9^{\circ} 42^{\prime} 53.2^{\prime \prime} \mathrm{N}, 83^{\circ} 51^{\prime} 25.1^{\prime \prime} \mathrm{W}, 2242 \mathrm{~m}$, epífitas en bosque pluvial montano, 5 Diciembre 2013, D. Bogarín 10530, F. Carbonell \& D. Jiménez. (JBL). Guanacaste: Abangares, Sierra, Monteverde, R.B. Monteverde. Chomogo, trail to Chomogo peak, Pacific slope and continental divide, cloud forest, 10.3333333, -84.8333333, 9 Nov 1985, W. Haber 3323 \& E. Bello (CR). Abangares, Sierra, Monteverde, Monteverde reserve, Pacific slope, lower montane wet forest, 10.3333333, -84.8333333, 30 Nov 1985, W. Haber $3647 \&$ E. Bello (CR). Volcán Tenorio, without more specific data, flowered in cultivation at Jardín Botánico Lankester, 23 Feb 1999, F. Pupulin 1361 (JBL). Volcán Tenorio (?). Recolector desconocido, sin fecha de recolecta en campo. Floreció en cultivo en Jardín Botánico Lankester el 28 de diciembre de 1999. Sépalos amarillo verdoso translúcido con venas rojizas y teñidos de rojo hacia las puntas. Sépalo dorsal muy cóncavo y cerrado sobre el resto de la flor. Pétalos rojos, verde claro en la base. Labelo rojo sangre. Columna verde claro. M. Blanco 1062 (USJ). Heredia: Heredia, Vara Blanca, Refugio de Vida Silvestre Cerro Dantas, orillas del Río Nuevo, $10^{\circ} 5^{\prime} 40.3^{\prime \prime} \mathrm{N}, 84^{\circ} 33^{\prime} 31.4^{\prime \prime} \mathrm{W}$, $1927 \mathrm{~m}$, bosque pluvial premontano, epífitas en bosque secundario, 28 diciembre 2008, D. Bogarín 6106 \& W. Salazar (JBL). Heredia, Varablanca, RVS Cerro Dantas, Bosque nuboso en refugio Cerro Dantas, sobre ladera caribe a $2 \mathrm{~km}$ después de Cerro Chompipe (entrada a torres del ICE), 10.0937222, -84.0590556, 22 Nov 2009, A. Cascante Marín 2145 \& J. Solano Zárate (CR). Heredia, Varablanca, El Gallito, above and west of Wet secondary forest about $15 \mathrm{~m}$ high, with many epiphytes, with frequent wind and rain from the Caribbean. Río Vueltas, (upper río Patria), eastern slope of Volcán Barva near the Continental Divide, 10.1000000, -84.0666667, about 2000 m, 22 Nov 1969, $W$. C. Burger 6396 \& R. L. Liesner (CR). Heredia, Varablanca, P.N. Braulio Carrillo. Lower montane rain forest formations and open pastures with frequent wind and rain from the Caribbean on the eastern slopes of Volcan Barva between the Río Las Vueltas and Río Nuevo (upper Río Nuevo) (upper Río Patria), 10.1000000, -84.0500000, 25 Oct 1975, W. C. Burger 9453 \& A. Baker (CR). San Isidro, $10^{\circ} 13^{\prime} \mathrm{N}$, 08400'W, 1700 m, 6 Nov 1991, Á. Fernández 157 (CR). Heredia, Vara Blanca, P.N. Braulio Carrillo, Park Refugio at $2050 \mathrm{~m}$ in 1 forest $0.5-1 \mathrm{~km} \mathrm{NE}$ of Refugio, 10.1777778, -84.1166667, 2100 m, 4 Nov 1990, S. Ingram 660 (CR). San Rafael, camino del Monte de La Cruz hacia el Refugio de Vida Silvestre Cerro Dantas, a orillas del Río Nuevo y la Quebrada Cabra, Reserva Forestal Cordillera Volcánica Central, $1800 \mathrm{~m}, 10^{\circ} 5^{\prime} 45^{\prime \prime} \mathrm{N}, 84^{\circ} 02^{\prime} 02^{\prime \prime} \mathrm{W}$, bosque pluvial premontano, epífitas en bosque secundario, 7 enero 2004, D. Bogarín 580, D. Lobo \& A. Vargas (JBL). Puntarenas: Puntarenas, Guacimal, R.B. Monteverde. Ojo de Agua, finca de Leonel Hernández, bosque pantanoso semiachaparrado, lado Pacífico de la reserve, 10.2500000, -84.7666667, 18 Nov 1997, W. Haber 7805 \& E. Bello (CR). Puntarenas, Guacimal, Z.P. Arenal-Monteverde, Ojo de Agua, Finca de Leonel Hernández, Bosque pantanoso semiachaparrado. Lado Pacífico de la reserva,10.2500000, -84.7666667, 1600 m, 18 Nov 1987, W. Haber 7792 (CR). San José: Moravia, San Jerónimo, Cerro de Zurquí, open pasture and remnants of lower montane rain forest formations on ridges and steep slopes along the Río Para Blanca (Pacific drainage), 10.0500000, -84.0166667, 21 Oct 1975, W. C. Burger 9316, K. Burt-Utley, J. F. Utley, R. A. Baker \& R. Bakes (CR). Vázquez de Coronado, Cascajal, P.N. Braulio Carrillo. Bajo de la Hondura, Wood on ridge above río Cascajal, 10.0166667, -83.9333333, 1 Jan 1977, R. W. Lent 4026 (CR). Limit between San Jose-Heredia: Moravia, San Jerónimo, P.N. Braulio Carrillo, Sitio Mojón de Cooper, entrando por Calle Zurquí, 10.0541667, -84.0222222, 1700 m, 6 Nov 1991, A. Fernández 157 (CR). Without specific locality data: C. H. Lankester 192/1920(K). Map 2.

C. The Pleurothallis cardiothallis group 9. Pleurothallis callosa M. Díaz \& Pupulin, sp. nov.

TYPE: Costa Rica. Cartago: Turrialba, Chirripó, El Seis (Damaris), 948'14.10"N, 83²6'38.70"O, $1200 \mathrm{~m}$, epiphytic on threes on the side of El Seis river, wet lower montane forest, 19 December 2018, G. Rojas-Alvarado 258, M. Cedeño, A. Karremans \& I. Chinchilla (Holotype: JBL). Fig. 21D, 24, 25 (Voucher, Rojas-Alvarado 258, JBL).

A Pleurothallide cardiothallide Rchb. $f$. similis, floribus concoloribus atrorubentis, labello conduplicato duobus calls prominentis in basi munito recedit.

Epiphytic, caespitose, erect herb to $30 \mathrm{~cm}$ tall. Roots slender, flexuous, ca. $1 \mathrm{~mm}$ in diam. Ramicauls terete, slender, 9.7-26.4 cm long, 1-2 mm in diam., grass green, provided with a tubular, truncate sheath to $2 \mathrm{~cm}$ long at the base, and a tubular, tightly adpressed, truncate sheath below the middle, to $5.1 \mathrm{~cm}$ long, the bracts glumaceous, pale green when young, becoming brown, dry-papyraceous with age. Leaf borne horizontally at the apex of the ramicaul, becoming subpendent with age, thinly coriaceous, sessile, narrowly ovate, acuminate, $10.5-13.5 \times 3.0-5.5 \mathrm{~cm}$, deeply cordate at the base, grass green, matte. Inflorescence a solitary flower, from a prostrate spathaceous bract ca. 1.5 $\mathrm{cm}$ long, green, dry-papyraceous when mature, eventually dissolving with age. Peduncle terete, slender, ca. $13 \mathrm{~mm}$ long. Pedicel terete, pale green, ca. $6 \mathrm{~mm}$ long. Ovary subclavate, terete, $7.5 \mathrm{~mm}$ long. Flowers solid dark red. Dorsal sepal erect, elliptic, acute, reflex, $17 \times 8-9 \mathrm{~mm}$, 5 -veined. Lateral sepals connate into a broadly ovate, acute, concave synsepal, 13-15 × 10-11 mm, 8-veined. Petals falcate to lanceolate, acute, $11.5 \times 1.0-1.5 \mathrm{~mm}, 1$-veined. 


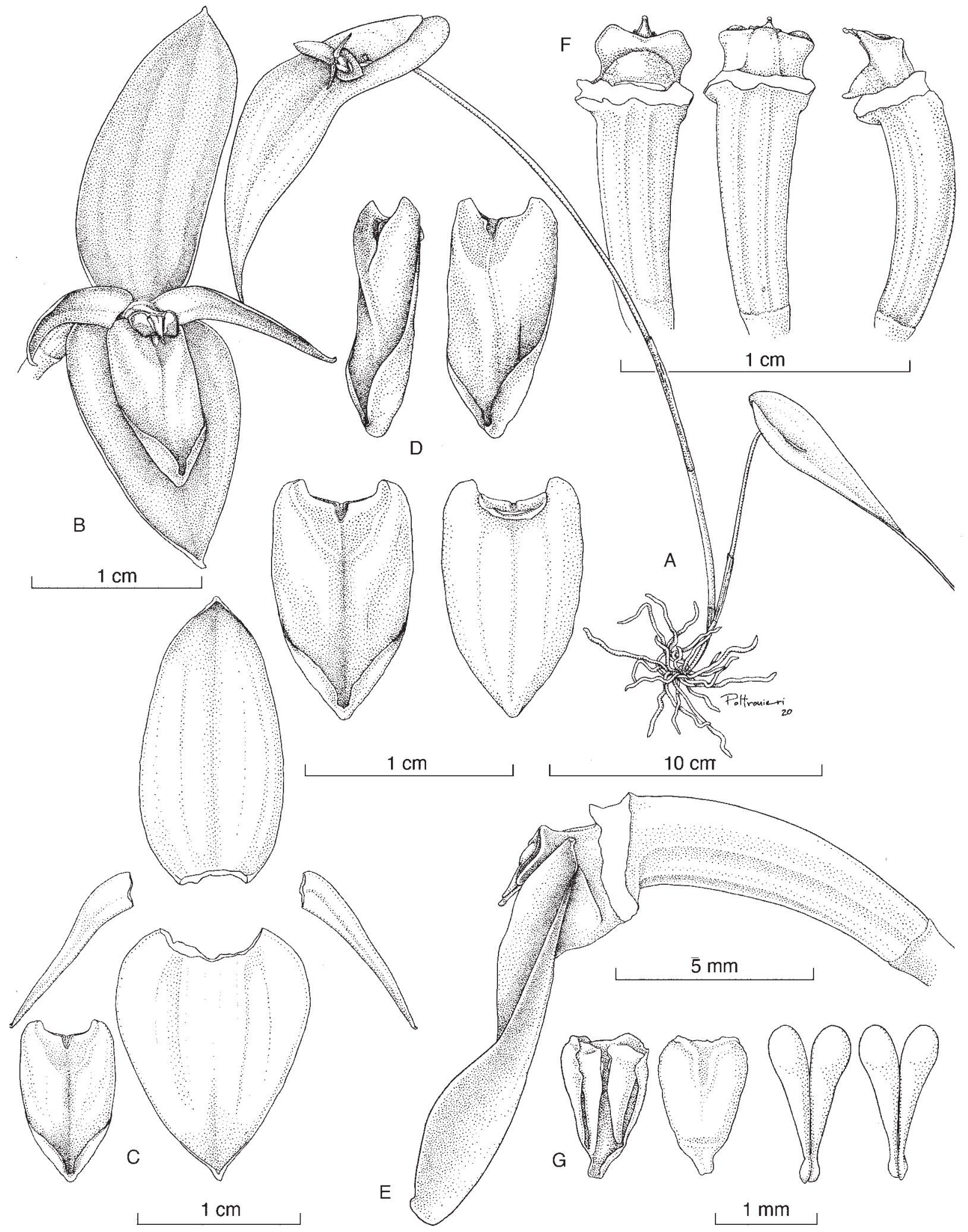

FIgure 24. Pleurothallis callosa M. Díaz \& Pupulin. A, habit; B, flower; $\mathbf{C}$, dissected perianth; D, lip in lateral, three-quarter, adaxial, and abaxial views; E, apex of ovary, column, and lip in lateral view; F, column in ventral, dorsal, and lateral views; G, anther cap (two views) and pollinarium (two views). Drawn by S. Díaz Poltronieri from Rojas-Alvarado 258 (JBL). 


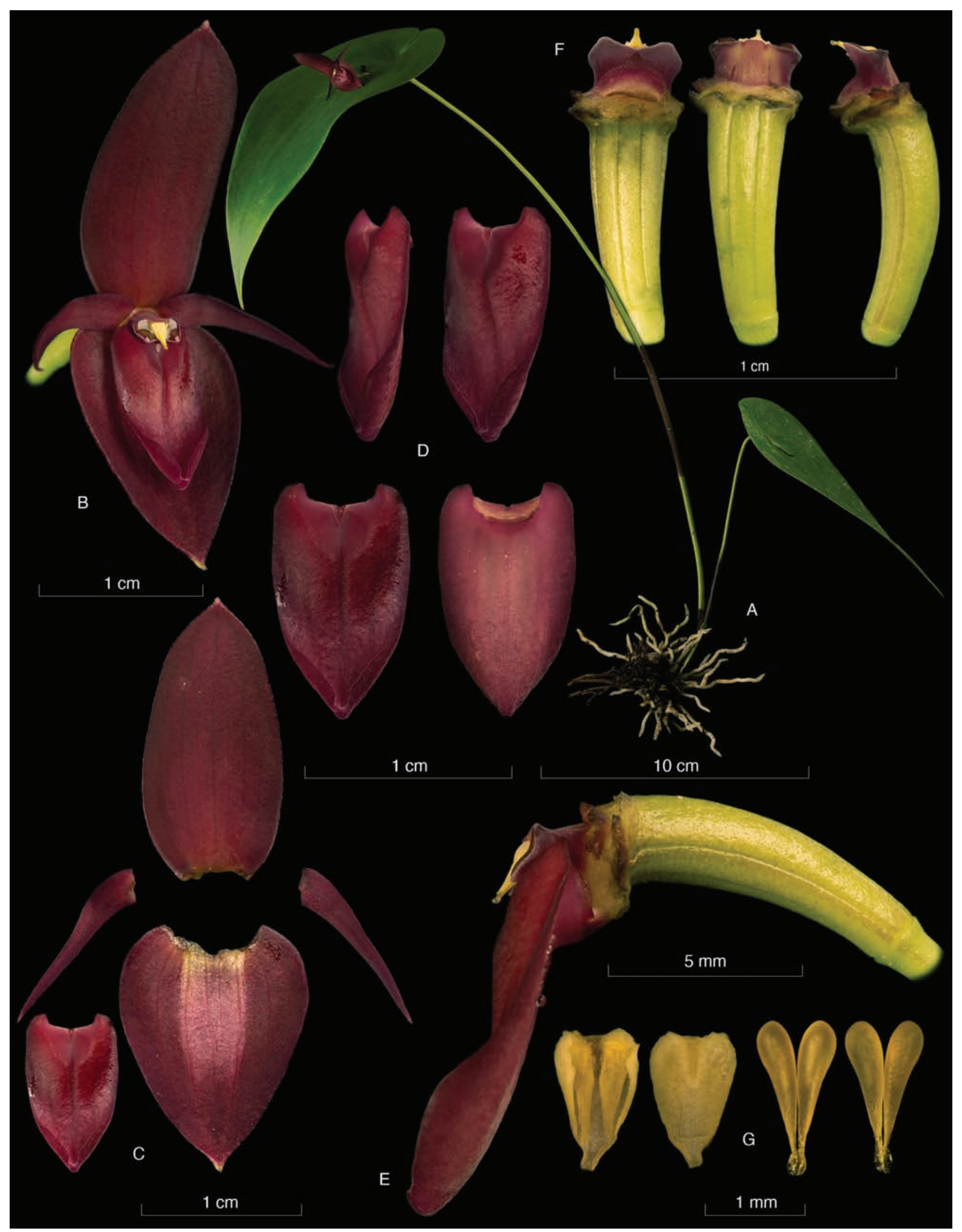

FIGURE 25. Pleurothallis callosa M. Díaz \& Pupulin. A, habit; B, flower; C, dissected perianth; D, lip in lateral, three-quarter, adaxial, and abaxial views; $\mathbf{E}$, apex of ovary, column, and lip in lateral view; $\mathbf{F}$, column in ventral, dorsal, and lateral views; G, anther cap (two views) and pollinarium (two views). Lankester Composite Dissection Plate prepared by M. Díaz from Rojas-Alvarado 258 (JBL). 
Lip unguiculate, hinged to the column foot, geniculate, peltate, basally truncate, conduplicate, obtuse, the margins involute in the apical half, $10.0-10.5 \times 6.5-7.0 \mathrm{~mm}$; glenion triangular, deeply recessed between 2 calli that extent to the basal half of the lip, $0.8 \mathrm{~mm}$ long. Column short, transversely subrectangular, dorsiventrally complanate, ca. 2.5-3.0 $\times$ $2.0 \mathrm{~mm}$, the anther apical, bent, the stigma apical, bilobed. Anther cap ovate, truncate, bilobed at the base, 2-celled, $1.4 \times 0.7 \mathrm{~mm}$. Pollinia 2 , narrowly oblong-pyriform, $1.5 \times$ $0.5 \mathrm{~mm}$, attached to an elliptic viscidium through 2 short, cylindric caudiculae.

Etymology: from the Latin callosus, "callose," in reference to the 2 prominent calli at the base of the lip that distinguish the species from its close relatives.

Distribution: known only from Costa Rica.

Ecology: the plants of the only population of Pleurothallis callosa known so far grow epiphytically in riparian forests at intermediate elevations (around $1200 \mathrm{~m}$ ) in the Caribbean watershed of the Cordillera de Talamanca, in a region characterized by high humidity and frequent precipitation. The species bloomed in cultivation in June.

Distinguishing features: the species is differentiated from other species of the $P$. cardiothallis group by the solid dark-red flowers and the prominent calli on the basal half of the conduplicate lip. Pleurothallis callosa has the general, peltate outline of the lip that can be found in several of the species close to $P$. cardiothallis, but it is comparatively larger and provided with 2 large, elliptic, rounded calli at the base that embrace the area of the glenion. The concolorous, darkred flower is superficially similar to that of P. scotinantha, but in the latter the lip is triangular, it is ecallose, and the flower is better described as dark purple in color instead of red.

Costa Rican material examined: Cartago: Turrialba, Chirripó, El Seis (Damaris), 948'14.10"N, 83²6'38.70"O, $1200 \mathrm{~m}$, epiphytic on threes on the side of El Seis river, wet lower montane forest, 19 December 2018, flowered in cultivation al Lankester Botanical Garden, 19 June 2020, G. Rojas-Alvarado 259, M. Cedeño, A. Karremans \& I. Chinchilla (voucher not preserved). Same locality data and collection date, flowered in cultivation al Lankester Botanical Garden, 19 June 2020, G. Rojas-Alvarado 260, M. Cedeño, A. Karremans \& I. Chinchilla (voucher not preserved). Same locality data and collection date, flowered in cultivation al Lankester Botanical Garden, 30 June 2020, G. Rojas-Alvarado 261, M. Cedeño, A. Karremans \& I. Chinchilla (voucher not preserved). Map 3.

10. Pleurothallis cardiothallis Rchb.f., Bot. Zeitung (Berlin) 15: 158. 1857. Humboltia cardiothallis (Rchb.f.) Kuntze, Revis. Gen. Pl. 2: 667. 1891. Acronia cardiothallis (Rchb.f.) Luer Monogr. Syst. Bot. Missouri Bot. Gard.

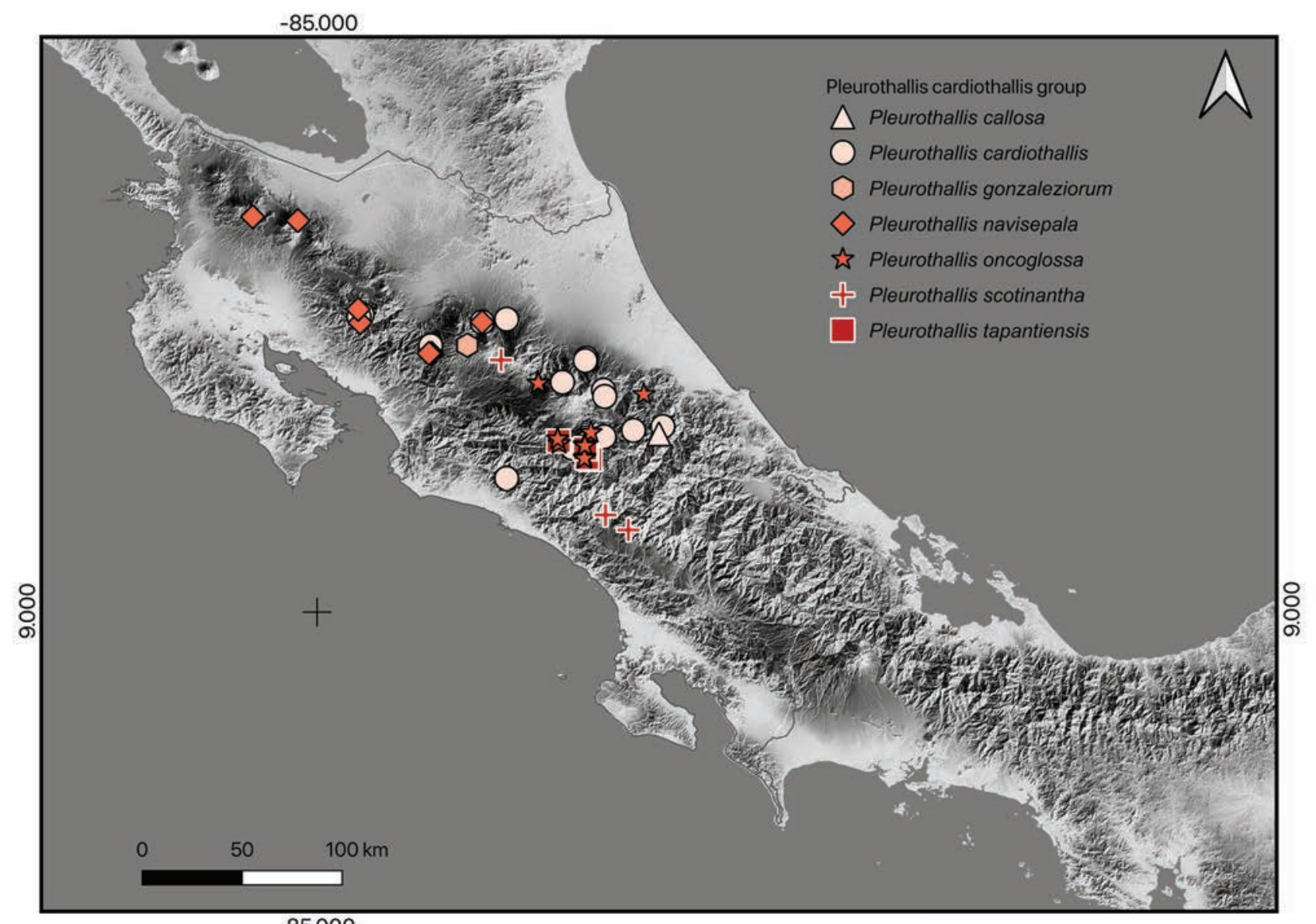

$-85.000$

MAP 3. Map of collection sites for the species of Pleurothallis cardiothallis group. 
103: 106. 2005. Zosterophyllanthos cardiothallis (Rchb.f.) Szlach. \& Kulak, Richardiana 6(4): 187. 2006. TYPE: Ex Anglia in hortum Schillerianum introducta, G. W. Schiller s.n. (Holotype: W). Pleurothallis subulata Rolfe, Bull. Misc. Inform. Kew 1892 (65-66): 137-138. 1892. TYPE: Without locality, "flowered in the collection of Baron Hruby, of Peckau, Bohemia, and was sent to Kew for determination through Messrs. F. Sander \& co., of St. Albans," T. Hruby s.n. (Holotype: K). Fig. 26 (Voucher, Pupulin 6414, JBL).

Epiphytic, caespitose, erect to suberect, large herb to $60 \mathrm{~cm}$ tall. Roots slender, flexuous, ca. $1 \mathrm{~mm}$ in diam. Ramicauls terete, slender, $15-50 \mathrm{~cm}$ long, $1.5-4.5 \mathrm{~mm}$ in diam., yellowish green, sometimes spotted with brown basally, provided with 2 tubular, short, broadly obtusetruncate sheaths to $4.5 \mathrm{~cm}$ long at the base, and a longer, tubular, tightly adpressed, obtuse-truncate sheath below the middle, to $7.5 \mathrm{~cm}$ long, the bracts glumaceous, pale green when young, becoming brown, dry-papyraceous with age. Leaf borne horizontally at the apex of the ramicaul, becoming subpendent with age, thinly coriaceous, flexible, sessile, ovate, acute to acuminate, 9-23 × 4-11 cm, deeply cordate at the base, grass green, matte. Inflorescence a solitary flower, usually produced singly, rarely in pairs, from a reclined spathaceous bract 9-27 mm long, brown, drypapyraceous when mature, eventually dissolving with age. Pedicel terete, green, 7-10 long. Ovary terete-subclavate, rounded in section, 5-9 $\mathrm{mm}$ long. Flowers mostly solid purple or solid yellow in Costa Rican populations, rarely with the dorsal sepals apically fading dull yellow, shortlived (usually 5, rarely 6 , days), with distinct temporary activity, becoming reflexed at anthesis completion. Dorsal sepal broadly ovate, subacute, 10-14 × 7.5-9.0 mm, 7- to 11-veined. Lateral sepals connate into a broadly ovate-subrounded, obtuse to subacute synsepal, 10-15 $\times$ 9-12 mm, 9- to 15-veined. Petals narrowly triangularsubfalcate, rarely subsygmoid, acuminate, 8-11 × 2.5-3.5 $\mathrm{mm}, 3$ - to 5-veined. Lip unguiculate, hinged to the column foot, geniculate, peltate-subrectangular, basally truncate with rounded angles, obtuse, 5-8 × 3.5-5.0 mm, strongly conduplicate at the base, the apical margins thickened, inrolled, finely pubescent abaxially; glenion deeply recessed between the thickened basal lobes of the lip, ca. $0.8 \mathrm{~mm}$ long. Column short, transversely subrectangular, dorsiventrally complanate, ca. $1.0 \times 2.5 \mathrm{~mm}$, the anther apical, bent, the stigma apical, bilobed. Anther cap obtriangular, acute, bilobed at the base, 2-celled, ca. $1.0 \times$ $0.7 \mathrm{~mm}$. Pollinia 2, narrowly oblong-pyriform, $1 \mathrm{~mm}$ long, attached to an elliptic viscidium through a short, cylindric caudicula. Figures 21E-F).

Etymology: from the Greek $x \breve{\alpha} \varrho \delta \breve{\iota}^{\prime} \bar{\alpha}$ (kardíā), "hearth," and $\theta \alpha \lambda \lambda$ ós (thallós), "stem," in reference to the heartshaped leaf borne at the apex of the secondary stem, or ramicaul.

Distribution: ranging from Mexico to Ecuador. In Costa Rica it has been recorded from both watersheds of the Continental Divide.

Ecology: growing as an epiphyte, both in primary and secondary forests, as well as in open areas in premontane and low montane wet forests, between 350 and $2000 \mathrm{~m}$. In Costa Rica, populations are known from both the Caribbean and Pacific drainages of the main mountain ranges. Plants have been found in bloom at least from April to January.

Distinguishing features: Pleurothallis cardiothallis can be recognized by the fully reflexed sepals and petals when anthesis is complete, and the peltate lip with the apical margins thickened and folded inward, revealing the papillose abaxial surface. It is similar to $P$. oncoglossa, from which it differs in the peltate lip (vs. distinctly triangular, with the apex thickened into a conical callus bent up as a hook), and $P$. navisepala, from which it differs in the much larger flowers (almost double the size) produced singly, very rarely in pairs (vs. 2-4 inflorescences at once), reflexed at maturity (vs. subringent at maturity).

Costa Rican material examined: Cartago: Paraíso, Orosi, Tapantí, Parque Nacional Tapantí, ca. $2 \mathrm{~km}$ después del Río Humo, 941'28.0"N, 8345'43.1"W, 1564 m, epífitas en árboles a orillas del camino en bosque pluvial premontano, 24 Marzo 2006, D. Bogarín 2667, G. Gigot \& J. Warner (JBL). Cartago, San Francisco, Muñeco, Finca Loma Verde y Jilguero, camino a Alto Belén, entre Río Sombrero y Quebrada Patarrá, 946'50.3"N, 8354'21.1"W, 1430-1620 $\mathrm{m}$, bosque pluvial premontano, epífitas en bosque secundario y árboles en zonas abiertas, 23 Mayo 2007, D. Bogarín 3843, M. Bonilla, R. Gómez, R. Trejos \& J.D. Zúñiga (JBL). Turrialba, Santa Cruz, Las Abras, ladera sureste del Volcán Turrialba, cerca de Río Guayabo, 958'56"N, 8344'46"W, $1946 \mathrm{~m}$, bosque pluvial premontano, epífitas en bosque secundario y árboles en potreros, 7 mayo 2007, D. Bogarín 3739, A. Karremans (JBL). Jiménez, Pejivalle, La Marta, shores of Río Gato, 947'27.2"N, 8341'37.2"W, 750 m, premontane wet forest, on trees along pastures edges and overhanging the river, 3 November 2006, F. Pupulin 6414, R. L. Dressler, R. Gómez, A. Karremans \& G. Rojas (JBL). Turrialba, Tayutic, Platanillo, laderas del Río Platanillo, 949'11"N, 8333'37"W, 700-900 m, 20 de febrero 2004, A. Karremans 139 (JBL). Turrialba, Tayutic, Moravia, 5 Kilometros al oeste del centro de Moravia, sobre sendero al lado de la calle que va a Platanillo, $9^{\circ} 50^{\prime} 12^{\prime \prime} \mathrm{N}, 83^{\circ} 25^{\prime} 35^{\prime \prime} \mathrm{W}$, 1000-1200 m, 22 de enero 2005, A. Karremans 659, D. Karremans y P. Ferreira (JBL). Paraíso, Hacienda Queverí de la familia Fernández Estrada, $1.5 \mathrm{~km}$ por el sendero hacia bosque primario, $9^{\circ} 44^{\prime} 23.14^{\prime \prime} \mathrm{N}, 83^{\circ} 50^{\prime} 18.42^{\prime \prime} \mathrm{W}$, $1790 \mathrm{~m}$, bosque pluvial montano bajo, en troncos caídos, 28 Enero 2014, M. Fernández 903, D. Bogarín \& M. Díaz (JBL). Cartago, San Francisco, Muñeco, Finca Loma Verde y Jilguero, camino a Alto Belén, entre Río Sombrero

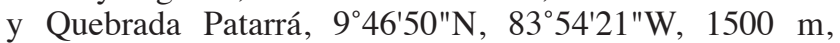
bosque pluvial premontano, epífitas en bosque secundario y árboles en zonas abiertas, 22 julio 2010, M. Fernández 110, D. Bogarín, R. Trejos \& C. Smith (JBL). Turrialba, Santa Teresita, Guayabo, Monumento Nacional Guayabo, alrededores de los senderos principales, $9^{\circ} 58^{\prime} 23.31^{\prime \prime} \mathrm{N}$, $83^{\circ} 41^{\prime} 28.73^{\prime \prime} \mathrm{W}, 1128 \mathrm{~m}$, bosque muy húmedo, epífitas, 26 mayo 2015, A. Karremans 6580, D. Bogarín \& F. Pupulin (JBL). Paraíso, Orosi, Purisil, orillas del Río Jaular, camino a Alto Jaular, ca. $1.5 \mathrm{~km}$ al sur de Purisil, $9^{\circ} 44^{\prime} 47.3^{\prime \prime} \mathrm{N}, 83^{\circ} 48^{\prime} 43.8^{\prime \prime} \mathrm{W}, 1406 \mathrm{~m}$, bosque muy húmedo premontano, epífitas en bosque secundario y potreros, 30 abril 2009, D. Bogarín 7005, M. Fernández, R. Gómez, Y. Kisel, F. Pupulin, P. Renshaw \& R. Trejos (JBL). Turrialba, 
VOL. 26, NO. 1

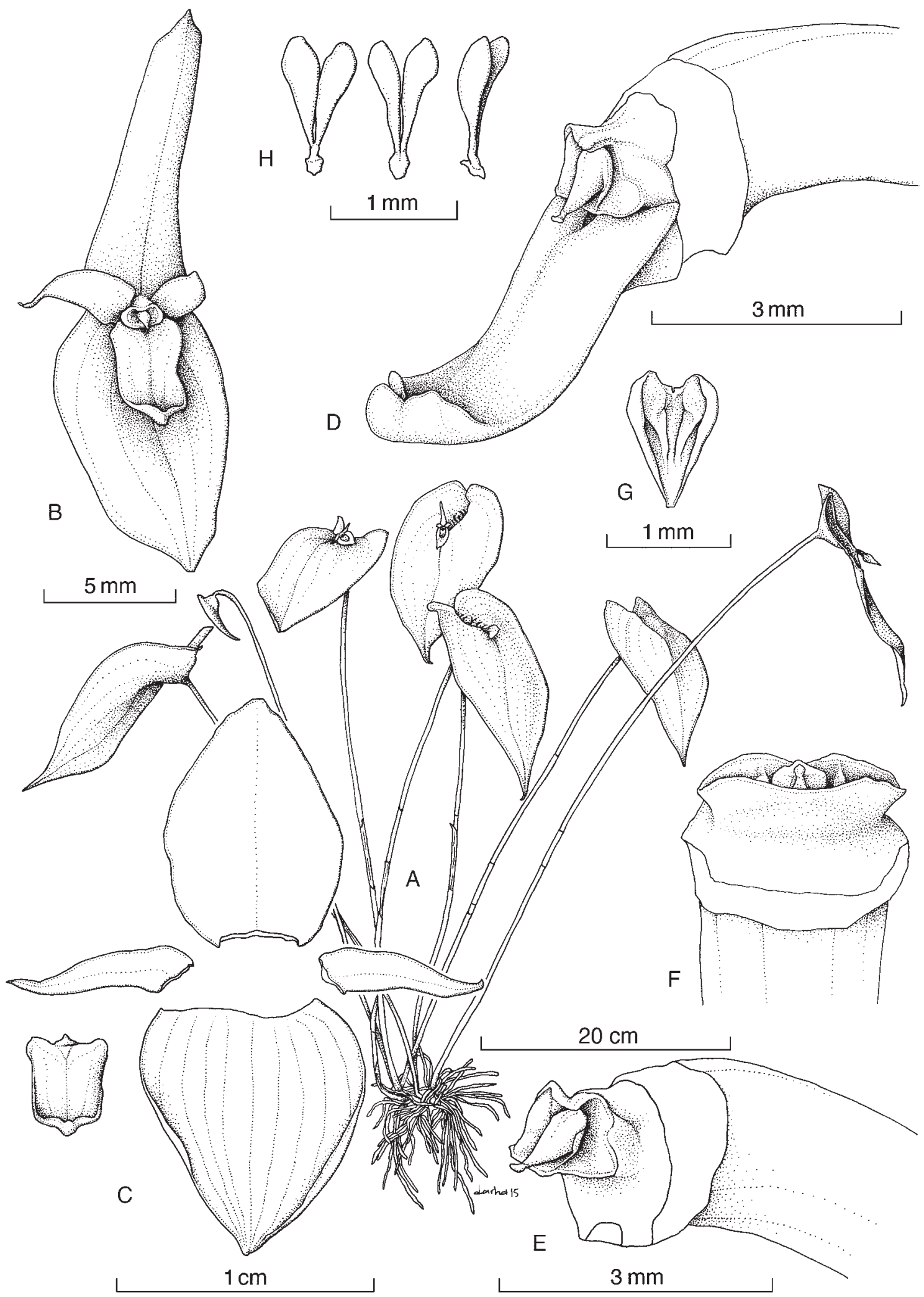

FIgURE 26. Pleurothallis cardiothallis Rchb.f. A, habit; B, flower; C, dissected perianth; D, apex of ovary, column, and lip in lateral view; E, column, lateral view; F, column, ventral view; G, anther cap; H, pollinarium (three views). Drawn by F. Pupulin and D. Solano Ulate from Pupulin 6414 (JBL). 
Santa Cruz-Santa Teresita, Guayabo Arriba, Torito, $50 \mathrm{~m}$ después del Caño Seco, en árboles solitarios del potrero de los Mesén, $10^{\circ} 00^{\prime} 06.23^{\prime \prime N}, 83^{\circ} 41^{\prime} 47.85^{\prime \prime W}, 1470$ m, 18 de Diciembre 2010, A. Karremas 3196, M. Contreras Fernandez (JBL). Heredia: Sarapiquí, La Virgen, Colonia Carvajal, Poza Azul, shores of Río Poza Azul, 10¹9'21.3"N, $84^{\circ} 08^{\prime} 19.1^{\prime \prime} \mathrm{W}, 662 \mathrm{~m}$, tropical wet, transition to premontane wet forest, epiphytic in secondary vegetation, flowers concolorous yellow, 13 May 2010, F. Pupulin 7843, D. Bogarín, M. Fernández, A. Karremans \& C. Smith (JBL). San Rafael, camino del Monte de La Cruz hacia el Refugio de Vida Silvestre Cerro Dantas, a orillas del Río Nuevo y la Quebrada Cabra, Reserva Forestal Cordillera Volcánica Central, $1800 \mathrm{~m}, 10^{\circ} 5^{\prime} 45^{\prime \prime} \mathrm{N}, 84^{\circ} 02^{\prime} 02^{\prime \prime} \mathrm{W}$, bosque pluvial premontano, epífitas en bosque secundario, 7 Enero 2004, D. Bogarín 590, D. Lobo \& A. Vargas (JBL). Limón: Pococí, Guápiles, Pocora, La Argentina Sur, márgenes del río Dos Novillos, sendero Las Cataratas, 500-700 m, bosque premontano muy húmedo, vegetación primaria madura, 12 de Setiembre 2004, R. Valverde 1341, E. \& D. Arias, J. Vásquez, G. Hidalgo \& P. Víquez (JBL). Pococí, Guápiles, Hacianda La Cuenca, bosque pluvial premontano, falda norte del Volcán Turrialba, $10^{\circ} 8^{\prime} 7.81^{\prime \prime} \mathrm{N}, 83^{\circ} 46^{\prime} 46.2^{\prime \prime} \mathrm{W}$, 611 m, 01 enero 2005, M. A. Blanco 2813, A. Cháves, L. du Toit \& C. Ugalde (JBL). Pococí, Guápiles. $5 \mathrm{~km}$ al sur de la carretera; fin del camino paralelo con el Río Blanco, cerca de la Finca Tintoreras; $10^{\circ} 02^{\prime} 16.2^{\prime \prime} \mathrm{N}, 83^{\circ} 53^{\prime} 02.1^{\prime \prime} \mathrm{W}$, 350-400 m, bosque muy húmedo tropical, 15 junio 2006, R. L. Dressler 6762, D. Bogarín, J. Gómez-Laurito, F. Pupulin (JBL). Without specific locality data: flowered in cultivation at Jardín Botánico Lankester, 21 Jun 2007, JBL02638 (JBL). Map 3.

11. Pleurothallis gonzaleziorum Pupulin, M. Díaz \& Pridgeon, Vanishing Beauty. Vol. 2: 855-857. TYPE: Costa Rica. Alajuela: Zarcero, Palmira, Reserva Biológica Bosque de Paz, creciendo en el jardín de orquídeas, $10^{\circ} 12^{\prime} 15.70^{\prime \prime} \mathrm{N}$, $84^{\circ} 19^{\prime} 00.02^{\prime \prime} \mathrm{W}, 1534 \mathrm{~m}$, bosque pluvial montano bajo, 20 agosto 2016, M. Díaz 269, N. Belfort-Oconitrillo \& A. Karremans (Holotype: JBL). Fig. 27 (Voucher, Díaz 269, JBL).

Epiphytic, caespitose, erect to suberect, large herb to $60 \mathrm{~cm}$ tall. Roots slender, flexuous, ca. $1 \mathrm{~mm}$ in diam. Ramicauls terete, slender, 25-40 cm long, 2.5-3.0 mm in diam., yellowish green, provided with 2 tubular, short, truncate sheaths to $3.8 \mathrm{~cm}$ long at the base, and a longer, tubular, tightly adpressed, broadly obtuse sheath below the middle, to $7.6 \mathrm{~cm}$ long, the bracts glumaceous, pale green when young, becoming brown, dry-papyraceous with age. Leaf borne horizontally at the apex of the ramicaul, becoming subpendent with age, thinly coriaceous, flexible, sessile, ovate, acuminate, $12.5-16.6 \times 6.5-8.3 \mathrm{~cm}$, deeply cordate at the base, grass green, matte. Inflorescence a solitary flower, usually produced singly, rarely in pairs, from a prostrate spathaceous bract $2.0-2.6 \mathrm{~cm}$ long, brown, drypapyraceous when mature, eventually dissolving with age. Pedicel terete, pale green, 17-22 mm long. Ovary clavate, terete, 8.5-9.0 mm long. Flowers glabrous, mostly solid pale yellow, sometimes red with the center fading yellow, with distinct temporary activity. Dorsal sepal broadly ovate, obtuse, $15.5-18.5 \times 12.5-16.0 \mathrm{~mm}$, 9- to 11-veined. Lateral sepals connate into a broadly ovate, obtuse to subacute synsepal, 14.5-16.0 × 13-16 mm, 10-veined. Petals narrowly triangular-falcate, acute, $11.5-12.0 \times 3.0-$ $3.5 \mathrm{~mm}$, 3-veined. Lip unguiculate, hinged to the column foot, geniculate, peltate, basally truncate with rounded angles, obtuse, 5.5-6.2 × 4.7-5.2 $\mathrm{mm}$, conduplicate at the base, the apical margins thickened; glenion deeply recessed between the thickened basal lobes of the lip, ca. $1 \mathrm{~mm}$ long. Column short, transversely subrectangular, dorsiventrally complanate, ca. $2.5 \times 3.0 \mathrm{~mm}$, the anther apical, bent, the stigma apical, bilobed. Anther cap obtriangular, acute, bilobed at the base, 2-celled, ca. $1.3 \times 1.0 \mathrm{~mm}$. Pollinia 2, narrowly oblong-pyriform, ca. $1.2 \mathrm{~mm}$ long, attached to an elliptic viscidium through a short, cylindric caudicula. Fruit an ellipsoid-clavate capsule, $5.1 \times 0.8 \mathrm{~cm}$ long.

Eponymy: the name honors Federico González's family from Bosque de Paz Biological Reserve where the species was found, and who has avidly supported orchid research in the reserve since 2004 .

Distribution: known only from Costa Rica, at 1500$1600 \mathrm{~m}$ in elevation.

Ecology: epiphytic in lower montane rain forest along the Caribbean slopes of the Cordillera Volcánica Central in Costa Rica.

Distinguishing features: Pleurothallis gonzaleziorum differs from $P$. cardiothallis by its distinctly triangular lip (vs. peltate), glabrous on the underside (vs. papillose), with the apical margins non involute. The lip is more similar to that of P. oncoglossa, but in the latter species the lip apex is thickened into a conical callus, bent back as a hook, whereas in P. gonzaleziorum it is straight and thin. By its triangular lip it is also similar to $P$. scotinantha, which however has much smaller, concolorous dark purple flowers.

As with other allied taxa close to Pleurothallis cardiothallis, $P$. gonzaleziorum also presents 2 different color morphs, one red and the other yellow (Fig. 21G-H), which grows sympatrically at the type locality.

Costa Rican material examined: Alajuela: Zarcero, Palmira, Bosque de Paz Biological Reserve, Gallery trail, $10^{\circ} 12^{\prime} 18.01^{\prime \prime} \mathrm{N}, 84^{\circ} 19^{\prime} 5.09^{\prime \prime} \mathrm{W}, 1585 \mathrm{~m}$, flowers red, fading yellow in center, 19 November 2016, M. Díaz 281, N. Belfort \& M. Kolanowska (JBL). Guanacaste: Tilarán, Quebrada Grande, road to Selvatura Adventure Park and Santa Elena Reserve, $10^{\circ} 20^{\prime} 23.5^{\prime \prime} \mathrm{N}, 84^{\circ} 48^{\prime} 34.5^{\prime \prime} \mathrm{W}, 1563 \mathrm{~m}$, wet lower montane forest, epiphytic in secondary forest on the side of the river, 6 March 2015, M. Fernández 1028, D. Bogarín, M. Díaz, F. Pupulin \& A. Salazar (JBL). Tilarán, Quebrada Grande, road to Selvatura Adventure Park and Santa Elena Reserve, $10^{\circ} 20^{\prime} 23.5^{\prime \prime} \mathrm{N}, 84^{\circ} 48^{\prime} 34.5^{\prime \prime} \mathrm{W}, 1563 \mathrm{~m}$, wet lower montane forest, epiphytic in secondary forest on the side of the river, 6 March 2015, M. Fernández 1035, D. Bogarín, M. Díaz, F. Pupulin \& A. Salazar (JBL). Map 3.

12. Pleurothallis navisepala Pupulin, J.Aguilar \& M. Díaz, Lankesteriana 17(2): 344. 2017.

TYPE: Costa Rica. Alajuela: San Ramón, Ángeles, Balsa, road between San Ramón and La Fortuna de San Carlos, 


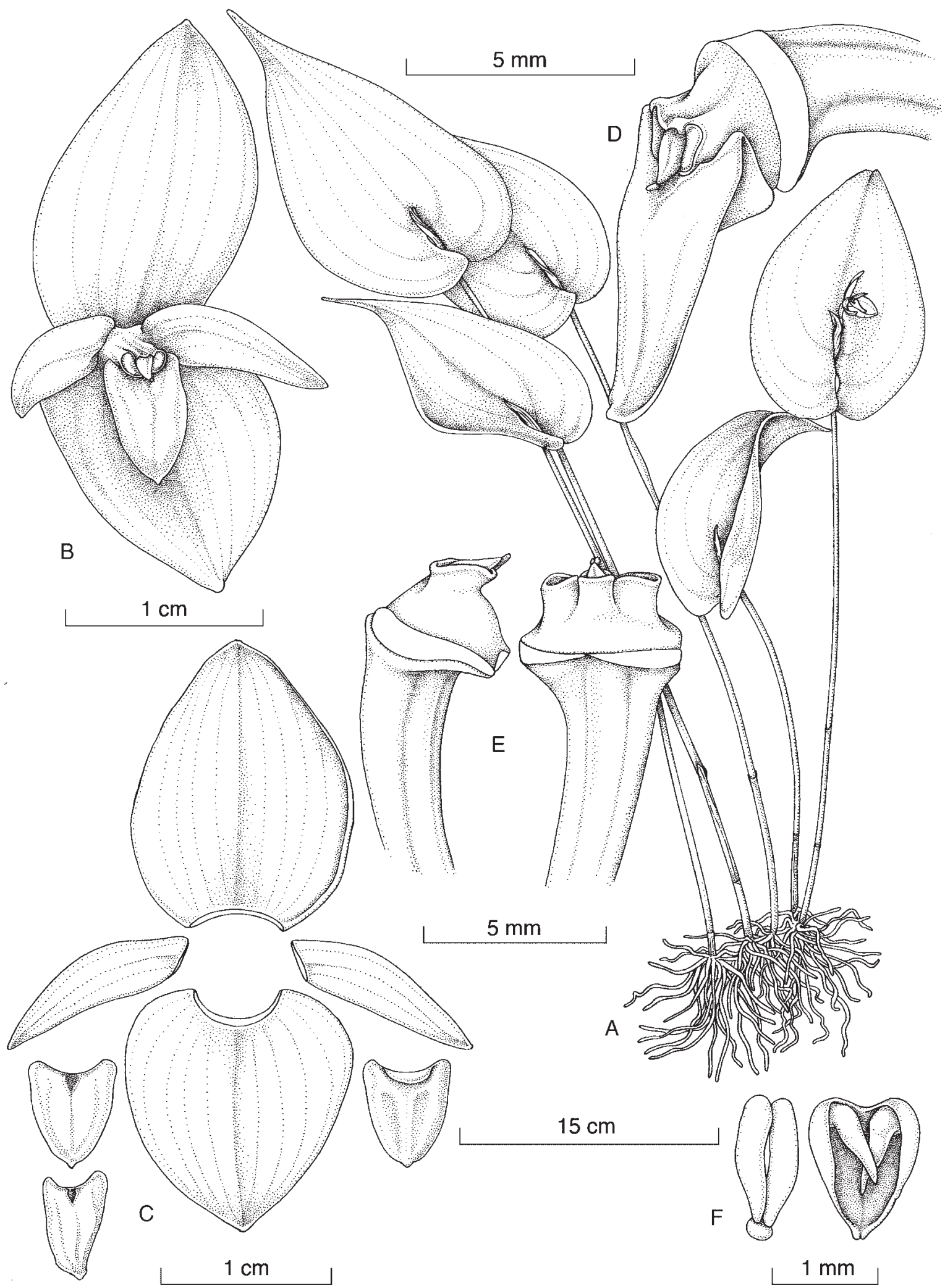

FIgure 27. Pleurothallis gonzaleziorum Pupulin, M. Díaz \& Pridgeon. A, habit; B, flower; C, dissected perianth (the lip in adaxial, threequarter, and abaxial views); D, apex of ovary, column, and lip in three-quarter view; E, column in lateral and dorsal views; F, anther cap and pollinarium (two views). Drawn by S. Díaz Poltronieri from M. Díaz 269 (JBL). From Pupulin, 2020. 
$10^{\circ} 10^{\prime} 03.6^{\prime \prime} \mathrm{N}, 84^{\circ} 29^{\prime} 35.7^{\prime \prime} \mathrm{W}, 1150 \mathrm{~m}$, epiphytic on trees in pastures close to Río Balsa, premontane rain forest, 29 May 2013, F. Pupulin 8435, D. Bogarín, M. Díaz, \& M. Fernández (Holotype: JBL). Fig. 28-30 (Vouchers, Pupulin 8028, Pupulin 8435 and Zúñiga 174, all at JBL).

Epiphytic, caespitose, erect to suberect, large herb to $25 \mathrm{~cm}$ tall. Roots slender, flexuous, ca. $1 \mathrm{~mm}$ in diam. Ramicauls terete, slender, $15-23 \mathrm{~cm}$ long, $0.2-0.3 \mathrm{~cm}$ in diam., yellowish green, provided with 2 tubular, short, obtuse sheaths to $1.5 \mathrm{~cm}$ long at the base, and a longer, tubular, tightly adpressed, subobtuse to truncate sheath below the middle, to $3.8 \mathrm{~cm}$ long, the bracts glumaceous, pale green when young, becoming brown, dry-papyraceous with age. Leaf borne horizontally at the apex of the ramicaul, becoming curved-subpendent with age, thinly coriaceous, flexible, sessile, ovate, narrowly acute to acuminate, 5.5$14.0 \times 3.0-7.5 \mathrm{~cm}$, deeply cordate at the base, grass green, matte. Inflorescence a solitary flower, usually produced singly, rarely in pairs, from a reclined spathaceous bract to $11 \mathrm{~mm}$ long, brown, dry-papyraceous when mature, eventually dissolving with age. Pedicel terete, green, 5-8 $\mathrm{mm}$ long. Ovary terete-subclavate, curved, rounded in section, 5-8 mm long. Flowers not completely spreading, with distinct temporary activity, short-lived (to 5 days), the sepals purple, sparklingly pale reddish and microscopically pubescent-glandulous abaxially, the synsepal with a large, basal, pale greenish yellow, hyaline blotch, the petals purple, the lip purple-magenta, or the entire flower concolorous bright yellow. Dorsal sepal erect, ovate, acute, 5.0-6.5 × 3.5-4.0 mm, the margins microscopically glandulose, 7 - to 9 -veined. Lateral sepals connate into a broadly ovate, obtuse, deeply cymbiform synsepal, the margins microscopically glandulose, 5.5-6.0 × 6.5-7.5 mm when spread, 9- to 11-veined. Petals narrowly triangularsubfalcate, subsygmoid, acuminate, 4.0-4.5 × 1.2-1.4 mm, correct, apically incurved, 3-veined. Lip unguiculate, hinged to the column foot, strongly geniculate, peltate, basally truncate with rounded angles, acute, apiculate, infolded, 5-8 $\times 3.5-5.0 \mathrm{~mm}$, strongly conduplicate at the base, the apical margins thickened, inrolled, finely pubescent abaxially; glenion recessed between the thickened basal lobes of the lip, ca. $0.8 \mathrm{~mm}$ long, the front of the glenion with a line of short papillae extending to the margins of the lip. Column short, transversely subrectangular, dorsiventrally complanate, ca. $1.0 \times 2.5 \mathrm{~mm}$, the anther apical, bent, the stigma apical, bilobed. Anther cap oblong, acute, bilobed at the base, 2-celled, ca. $1.0 \times 0.5 \mathrm{~mm}$. Pollinia 2, narrowly oblongpyriform, $1 \mathrm{~mm}$ long, attached to an elliptic viscidium through a short, cylindric caudicula. Fig. 21I, 31A.

Etymology: from the Latin navis, "ship," and sepala, "sepals," in reference to the boat-shaped synsepal that is characteristic of the species.

Distribution: known only from northwestern Costa Rica.

Ecology: epiphytic on branches of the lower canopy in premontane moist and premontane wet forest along the Caribbean watershed of the Cordillera de Tilarán and the Cordillera Volcánica de Guanacaste, at 850-1150 m in elevation. Flowering occurs between October and February.

Distinguishing features: the deeply concave shape of the synsepal, which is almost saccate at the base, prevents the perianth from spreading out completely at anthesis, and the bilabiate flower remains therefore somewhat cupped. This relatively small flower on a large-sized plant and the flower shape with the lip enclosed within the erect margins of the sysnsepal are unique within the group and easily recognizable.

Most of the known specimens of Pleurothallis navisepala come from a quite restricted area along the Caribbean drainage of the Cordillera de Tilarán southern end, where it is apparently frequent. It was first collected and illustrated around 1867 by August R. Endrés in a locality called "Legua" de San Ramón, likely one of the localities crossed by the new road that the Costa Rican government was building from San Ramón toward the northern San Carlos plains, where the species is still fairly common.

Costa Rican material examined: Alajuela: [San Ramón, Ángeles], Legua, Endres Pleurothallis no. 52, A. R. Endrés s.n. (W 0020259). San Ramón, Ángeles, Balsa, road between San Ramón and La Fortuna de San Carlos, $10^{\circ} 10^{\prime} 03.6^{\prime \prime} \mathrm{N}, 84^{\circ} 29^{\prime} 35.7^{\prime \prime} \mathrm{W}, 1150 \mathrm{~m}$, epiphytic on trees in pastures close to Río Balsa, premontane rain forest, 29 May 2013, F. Pupulin 8434, D. Bogarín, M. Díaz, \& M. Fernández (JBL); same collecting data, F. Pupulin 8446, D. Bogarín, M. Díaz, \& M. Fernández (JBL). Balsa, Reserva Biológica A.M. Brenes, 800-1000 m, 19 June 1995, flowered in cultivation at the Lankester Botanical Garden, 25 Sept. 2002, G. Carnevali \& A. C. Rodríguez s.n. under JBL-00787 (JBL). San Ramón, Balsa, Reserva Biológica A.M. Brenes, 10 Dec. 1991, flowered in cultivation at the Lankester Botanical Garden, flowers yellow, 8 Sept. 2008, M. Freiberg s.n. under JBL-02746 (JBL). Without specific locality, collected by D. Matamoros, 2010, flowered in cultivation at Jardín Botánico Lankester, 10 January 2011, F. Pupulin 8028 (JBL). Without collecting data, flowered in cultivation at Jardín Botánico Lankester, 20 Feb. 1999, F. Pupulin 1342 (JBL).Upala, Bijagua, Zapote, Finca La Escondida, ca. $5 \mathrm{~km}$ de la entrada de la finca hacia la ladera noreste del Volcán Miravalles, $10^{\circ} 46^{\prime} 00.8^{\prime \prime} \mathrm{N}, 8^{\circ} 05^{\prime} 35.7 " \mathrm{~W}$, 900-1000 m, bosque pluvial premontano, epífitas en bosque secundario, 3 Feb. 2006, Bogarín 2501, J. Barrantes, $R$. L. Dressler, R. Gómez \& A. Rojas (JBL). Without specific locality, flowered in cultivation at Lankester Botanical Garden, 20 Dec. 2016, JBL-33356 (JBL). Guanacaste: Liberia, Liberia, Parque Nacional Rincón de la Vieja, the SE slopes of Volcán Santa María, above Estación Hacienda Santa María. Evergreen montane forest, 10.7833333, -85.3000000, 27 Jan 1983, G. Davidse 23418 et al. (CR). Tilarán, Tronadora, R.B. Monteverde. $5 \mathrm{~km}$ n of Santa Elena on road to Las Nubes, Finca San Bosco road, Río Negro, Atlantic slope, 10.3666667, -84.8166667, 10 Nov 1988, $W$. Haber 8755 \& W. Zuchowski (CR). Map 3.

13. Pleurothallis oncoglossa Luer, Lindleyana 1: 86. 1996. Acronia oncoglossa (Luer) Luer, Monogr. Syst. Bot. Missouri Bot. Gard. 103: 166, f. 142. 2005. Zosterophyllanthos oncoglossus (Luer) Szlach. \& Kulak, Richardiana 6: 191. 2006. TYPE: Costa Rica. Without collection data, collected by Leon Glicenstein, flowered in 
VOL. 26, NO. 1

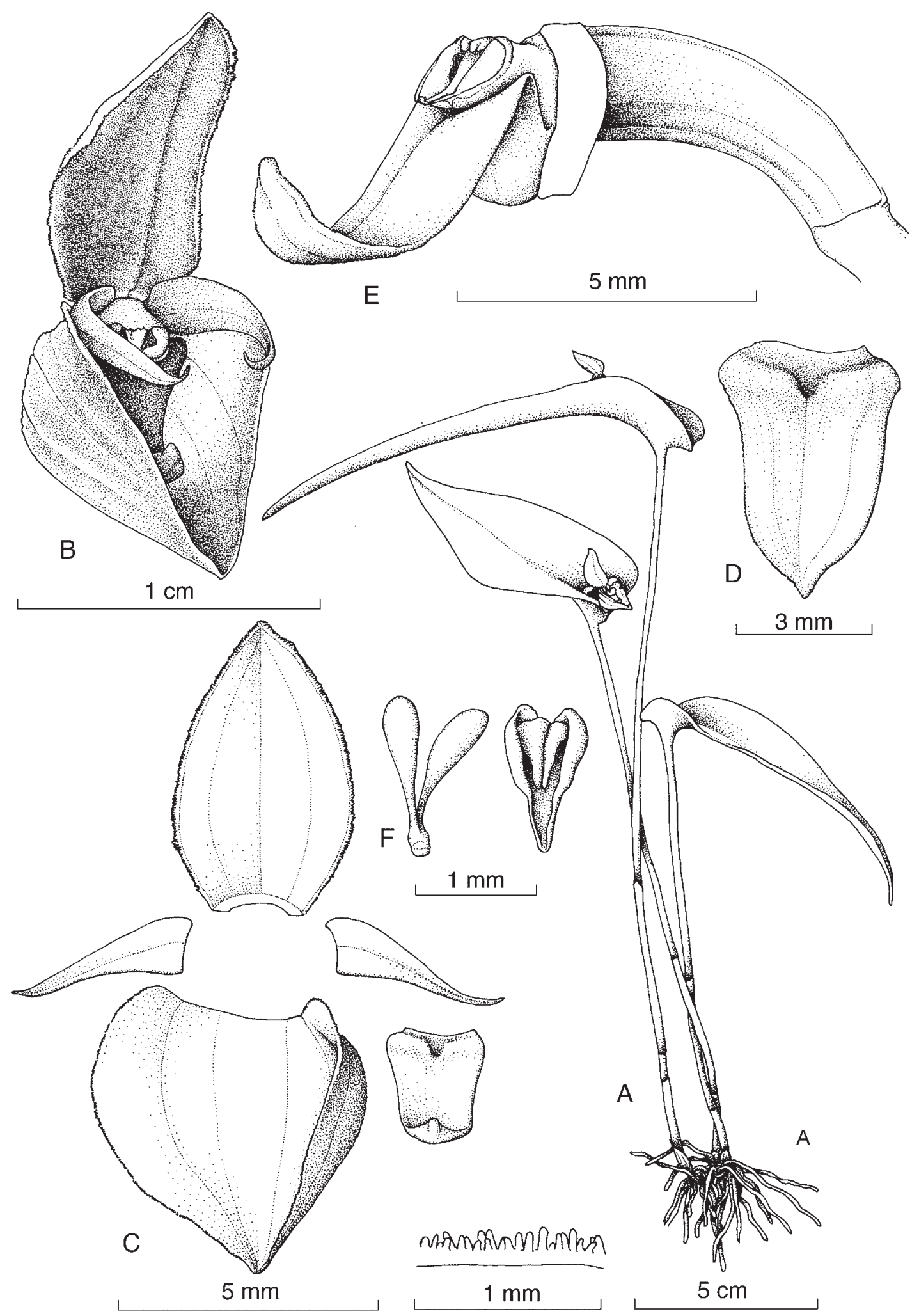

FIGURe 28. Pleurothallis navisepala Pupulin, J. Aguilar \& M. Díaz. A, habit; B, flower; C, dissected perianth; D, lip, adaxial view; E, apex of ovary, column, and lip in lateral view; F, pollinarium and anther cap. Drawn by F. Pupulin and D. Solano Ulate from Pupulin 8028 (JBL). Reproduced with permission from the Editor of Lankesteriana. 

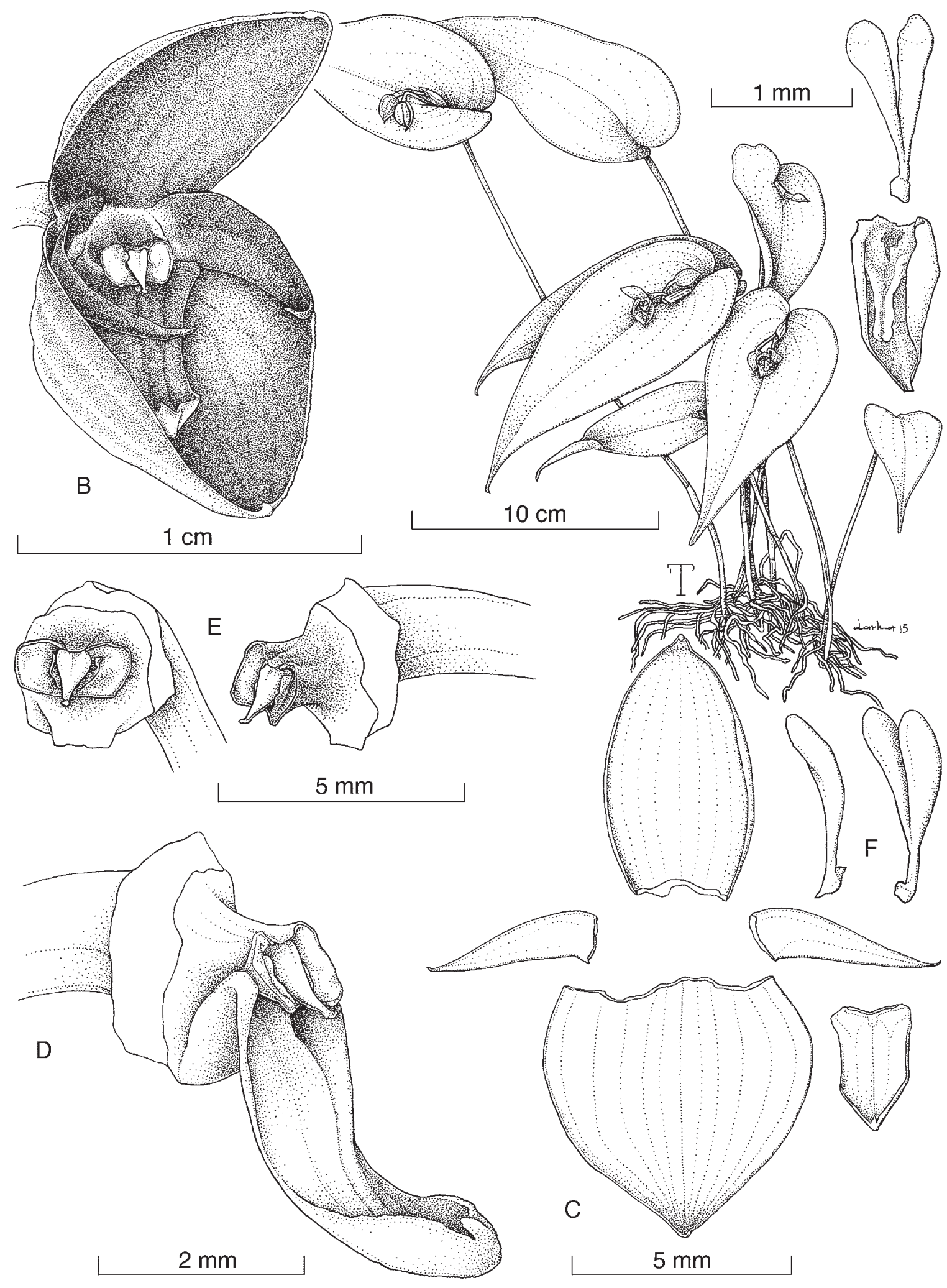

Figure 29. Pleurothallis navisepala Pupulin, J. Aguilar \& M. Díaz. A, habit; B, flower; C, dissected perianth; D, apex of ovary, column, and lip in lateral view; E, column in front and lateral views; F, pollinarium, lateral and three quarters views. Drawn by F. Pupulin and D. Solano Ulate from Pupulin 8435 (JBL). 

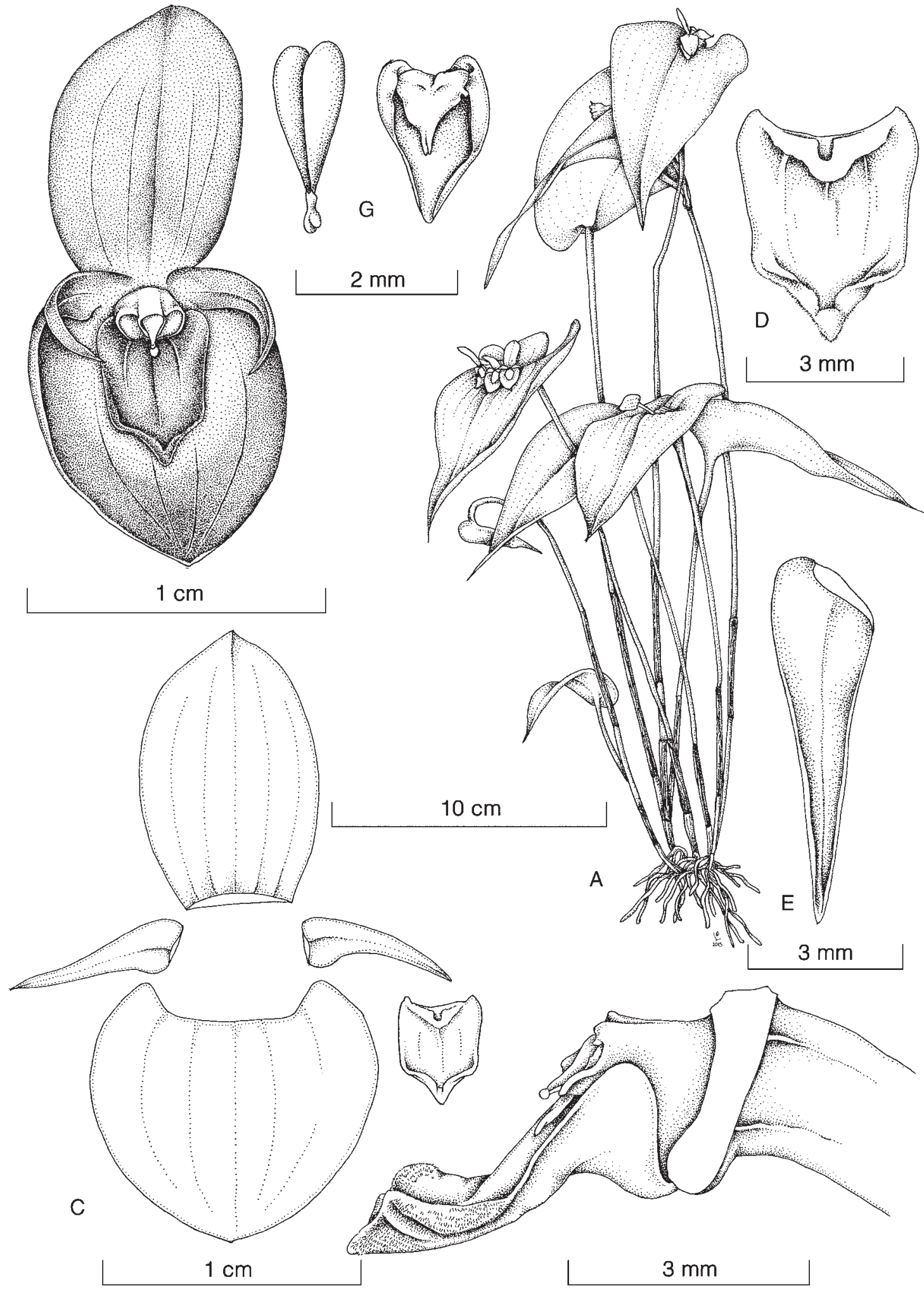

Figure 30. Pleurothallis navisepala Pupulin, J. Aguilar \& M. Díaz. A, habit; B, flower; C, dissected perianth; D, lip, adaxial view; $\mathbf{E}$, right petal; F, apex of ovary, column, and lip in lateral view; G, pollinarium and anther cap. Drawn by L. Oses from Zúñiga 174 (JBL). 


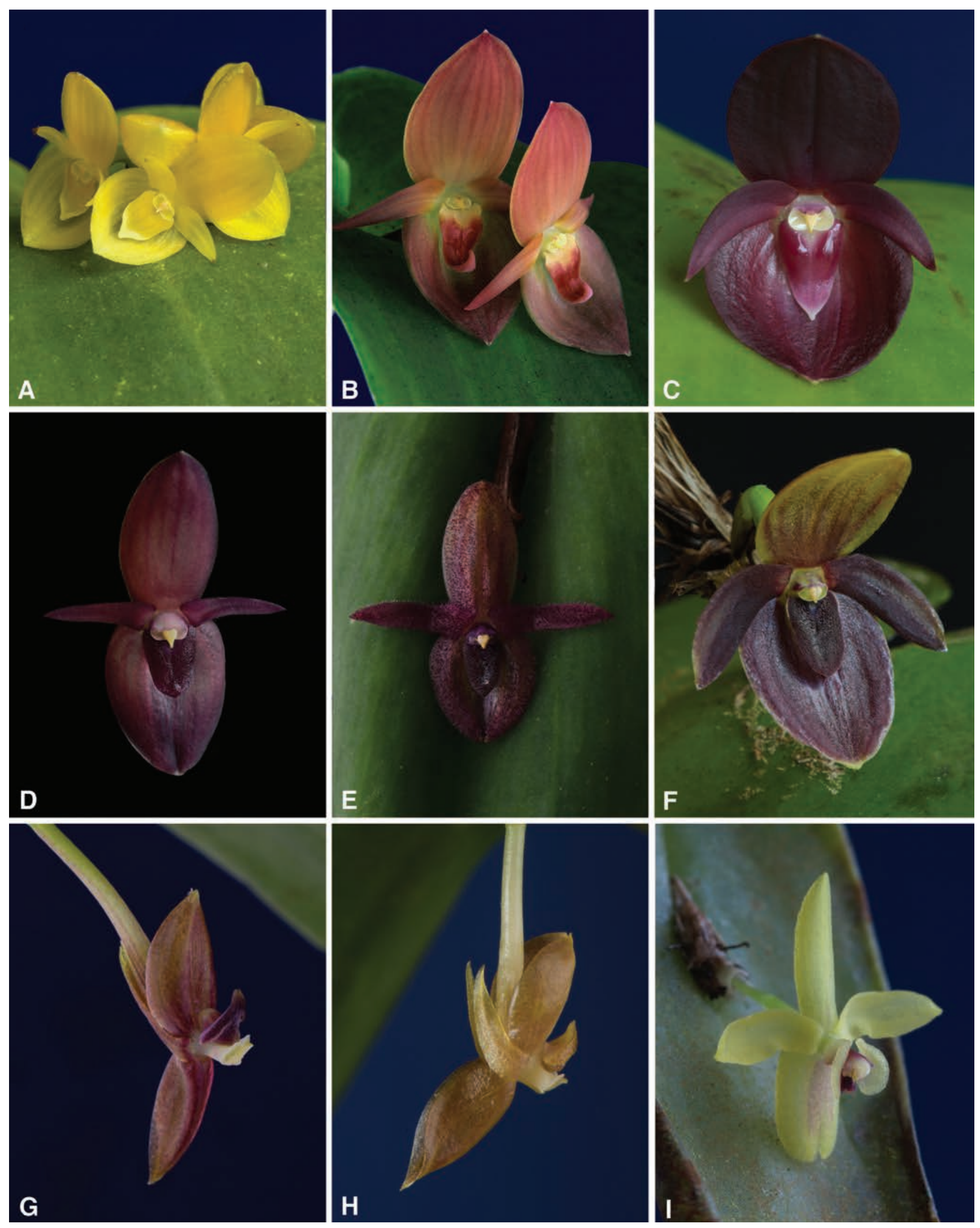

FIGURE 31. Flowers of Pleurothallis species from Costa Rica in the P. cardiothallis (A-C) and P.phyllocardia (D-I) groups. A, P. navisepala (Bogarín 2501); B, P. oncoglossa (JBL-01976); C, P. scotinantha (Bogarín 7355); D, P. tapantiensis (Bogarín 11273); E, P. adventurae (Bogarín 7696); F, P. anthurioides (Bogarín 10649); G-H, P. compressa (Bogarín 7839; Karremans 2503); I, P. fantastica (Blanco 5087). Not at the same scale. All the vouchers at JBL. Photographs by F. Pupulin. 
cultivation by P. \& A. Jesup in Bristol, CT, 10 Dec. 1988, C. Luer 13833 (Holotype: MO). Fig. 32 (Voucher, Bogarín 5686, JBL).

Epiphytic, caespitose, erect herb, to $38 \mathrm{~cm}$ tall. Roots slender, flexuous, ca. $1 \mathrm{~mm}$ in diam. Ramicauls terete, slender, 12-31 cm long, 1-3 mm in diam., yellowish green, provided with a tubular, short, truncate sheath, $1.0-2.5 \mathrm{~cm}$ long at the base, and a longer, tubular, tightly adpressed, truncate sheath below the middle, to 5-11 cm long, the bracts brown, dry-papyraceous. Leaf borne suberect at the apex of the ramicaul, becoming subpendent with age, thinly coriaceous, flexible, sessile, ovate, acuminate, 10.5-14.5 $\times 4.5-5.5 \mathrm{~cm}$, deeply cordate at the base, matte green. Inflorescence a solitary flower, from a prostrate spathaceous bract 1-2 cm long, brown, dry-papyraceous when mature, eventually dissolving with age. Pedicel terete, pale green, ca. $12 \mathrm{~mm}$ long. Ovary subclavate, terete, ca. $11.5 \mathrm{~mm}$ long. Flowers dark red on a pale-yellow background visible on the base of the petals, sepals, and lip. Dorsal sepal broadly ovate, obtuse, 15-17 × 12-15 mm, 9-veined. Lateral sepals connate into a broadly ovate, obtuse synsepal, 14$16 \times 14-16 \mathrm{~mm}, 9$ - to 10 -veined. Petals narrowly ovatefalcate, acute, 11-12 × 3-4 mm, 3-veined. Lip unguiculate, hinged to the column foot, geniculate, triangular, basally truncate with rounded angles, acute, $7-8 \times 4-5 \mathrm{~mm}$, the apex thickened into a conical callus bended up as a hook; glenion recessed in the middle of the base of the lip, slender, ca. $1 \mathrm{~mm}$ long. Column short, transversely subrectangular, dorsiventrally complanate, ca. $3 \times 4 \mathrm{~mm}$, the anther apical, bent, the stigma apical, bilobed. Anther cap cordate, acute, bilobed at the base, bent up at the apex, 2-celled. Pollinia 2 , narrowly oblong-pyriform, bent up at the apex, attached to an elliptic viscidium through a short, cylindric caudicula. Fig. 31B.

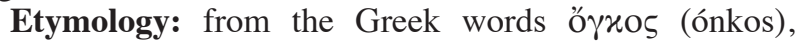
"topknot on the masks of classic tragedy," and $\gamma \lambda \hat{\omega} \sigma \sigma \breve{\alpha}$ ( lôssa), "tongue," in reference to the callous projection at the apex of the lip.

Distribution: known only from Costa Rica.

Ecology: epiphytic in premontane wet forests of the northern Cordillera Volcánica Central and Cordillera de Talamanca foothills, apparently restricted to the Caribbean watershed between 1250 and $2100 \mathrm{~m}$. Flowering has been recorded from October to February.

Distinguishing features: Pleurothallis oncoglossa is similar to $P$. cardiothallis, from which it differs in the distinctly triangular lip with the apex thickened into a conical callus, bent up as a hook (vs. peltate). Pleurothallis oncoglossa is also similar to $P$. scotinantha, but in the latter the lip is not hooked and the perianth is solid dark purple instead of dark red on a pale-yellow background.

Costa Rican material studied: Cartago: Cartago, San Francisco, Muñeco, Navarro, ca. $5 \mathrm{~km}$ al sur de la iglesia de Navarro, entre Río Sombrero y Quebrada Patarrá, camino a Alto Belén, bosque pluvial premontano, $9^{\circ} 45^{\prime} 38.28^{\prime \prime} \mathrm{N}$, 8353'56.81"W, 1808 m, 3 feb. 2017, D. Bogarín 12227, M. Cedeño, M. Fernández \& E. Kaes (JBL). Cartago, San Francisco, Muñeco, Finca Loma Verde y Jilguero, camino a Alto Belén, entre Río Sombrero y Quebrada Patarrá, $9^{\circ} 46^{\prime} 50.3^{\prime \prime} \mathrm{N}, 83^{\circ} 54^{\prime} 21.1^{\prime \prime} \mathrm{W}, 1430-1620 \mathrm{~m}$, bosque pluvial premontano, epífitas en bosque secundario y árboles en zonas abiertas, 23 mayo 2007, D. Bogarín 3843, M. Bonilla, R. Gómez, Rafael Trejos \& J. D. Zúñiga (JBL). Cartago: Cartago, San Francisco, Muñeco, Finca Loma Verde y Jilguero, camino a Alto Belén, entre Río Sombrero y Quebrada Patarrá, 946'50"N, 83⒌'21"W, 1500 m, bosque pluvial premontano, epífitas en bosque secundario y árboles en zonas abiertas, 22 Jul 2010, M. Fernández 110. D. Bogarín, R. Trejos \& C. Smith (JBL). Jiménez, Pejibaye, Tucurrique, Bajos del Humo, between the rivers Humo and Vueltas, east side of Cerros Duán, $9^{\circ} 48^{\prime} 36.7^{\prime \prime} \mathrm{N}$, $83^{\circ} 45^{\prime} 16.2^{\prime \prime} \mathrm{W}, 1396 \mathrm{~m}$, rainy low montane forest, epiphytic on trees in paddocks and forest borders, 24 Nov 2008, $D$. Bogarín 5686, R. L. Dressler, R. Gómez \& R. Trejos (JBL). Jiménez, Pejibaye, Tucurrique, Bajos del Humo, entre ríos Humo y Vueltas, ladera este de Cerros Duán, 9 48'36.7"N, $83^{\circ} 45^{\prime} 16.2^{\prime \prime} \mathrm{W}, 1396 \mathrm{~m}$, bosque pluvial montano bajo, epífitas en árboles en potreros y borde de bosque, 24 Nov 2008, $D$. Bogarín 5711, R. L. Dressler, R. Gómez \& R. Trejos (JBL); same collecting data, D. Bogarín 5712, R. L. Dressler, R. Gómez \& R. Trejos (JBL); same collecting data, D. Bogarín 5723, R. L. Dressler, R. Gómez \& R. Trejos (JBL); same collecting data, D. Bogarín 5726, R. L. Dressler, R. Gómez, $\&$ R. Trejos (JBL); same collecting data, D. Bogarín 5728, R. L. Dressler, R. Gómez \& R. Trejos (JBL); Paraíso, Orosi, Purisil, ca. $1450 \mathrm{~m}$, epiphytic in lower montane wet forest, secondary forest, 18 Oct 2001, F. Pupulin 3342 (JBL). Paraíso, Orosi, Tapantí, Parque Nacional Tapantí, entre Río Villegas y Río Dos Amigos, 941'32.9"N, 8347'03.2"W, $1650 \mathrm{~m}$, epífitas en árboles a orillas del camino en bosque pluvial premontano, 3 Mar 2009, D. Bogarín 6323, R. L. Dressler, R. Gómez \& R. Trejos (JBL). Turrialba, Torito, road to Santa Teresa, along a small creek, wet premontane forest, on scattered trees in a pasture, 31 July 1998, F. Pupulin 973, R. L. Dressler, D. E. Mora, K. Dressler \& M. Retana (JBL); same collecting data, F. Pupulin 977, R. L. Dressler, D. E. Mora, K. Dressler \& M. Retana (JBL). Turrialba, Santa Cruz, Las Abras, ladera sureste del Volcán Turrialba, cerca de Río Guayabo, 9 58'56"N, 83³0'46"W, 2100-1700 m, bosque pluvial premontano, epífitas en bosque secundario y árboles en potreros, 7 mayo 2007, D. Bogarín $3739 \& A$. Karremans (JBL). Paraíso, Orosi, Tapantí, Parque Nacional Tapantí, final del sendero Oropéndola, epífitas a orillas de la calle principal, 50-300 m antes de la entrada a sendero Oropéndola, 9,749669507 -83,78184389 1286 m bosque pluvial premontano, 28 de enero de 2019, Fernández 1320 \& D. Bogarín (JBL). Limón: Siquirres, Florida, Destierro, cabeceras Río Destierro, cerca de Roca, 10.0561111, -83.6961111, 1400-1500 m, 9 diciembre 2008, J. F. Morales Quirós 17256 (CR). Without collecting data: flowered in cultivation at Jardín Botánico Lankester, 30 Dec. 1999, F. Pupulin 1903 (JBL); flowered in cultivation at Jardín Botánico Lankester, 21 Jan. 1999, JBL-01976 (JBL). Map 3.

14. Pleurothallis scotinantha Pupulin, J. Aguilar \& M. Díaz, Lankesteriana 17(2): 337. 2017. TYPE: Costa Rica. San José: Pérez Zeledón, Cajón, Montecarlo, 3.5 km al noreste de Montecarlo, orillas del Río Peña Blanquita, 


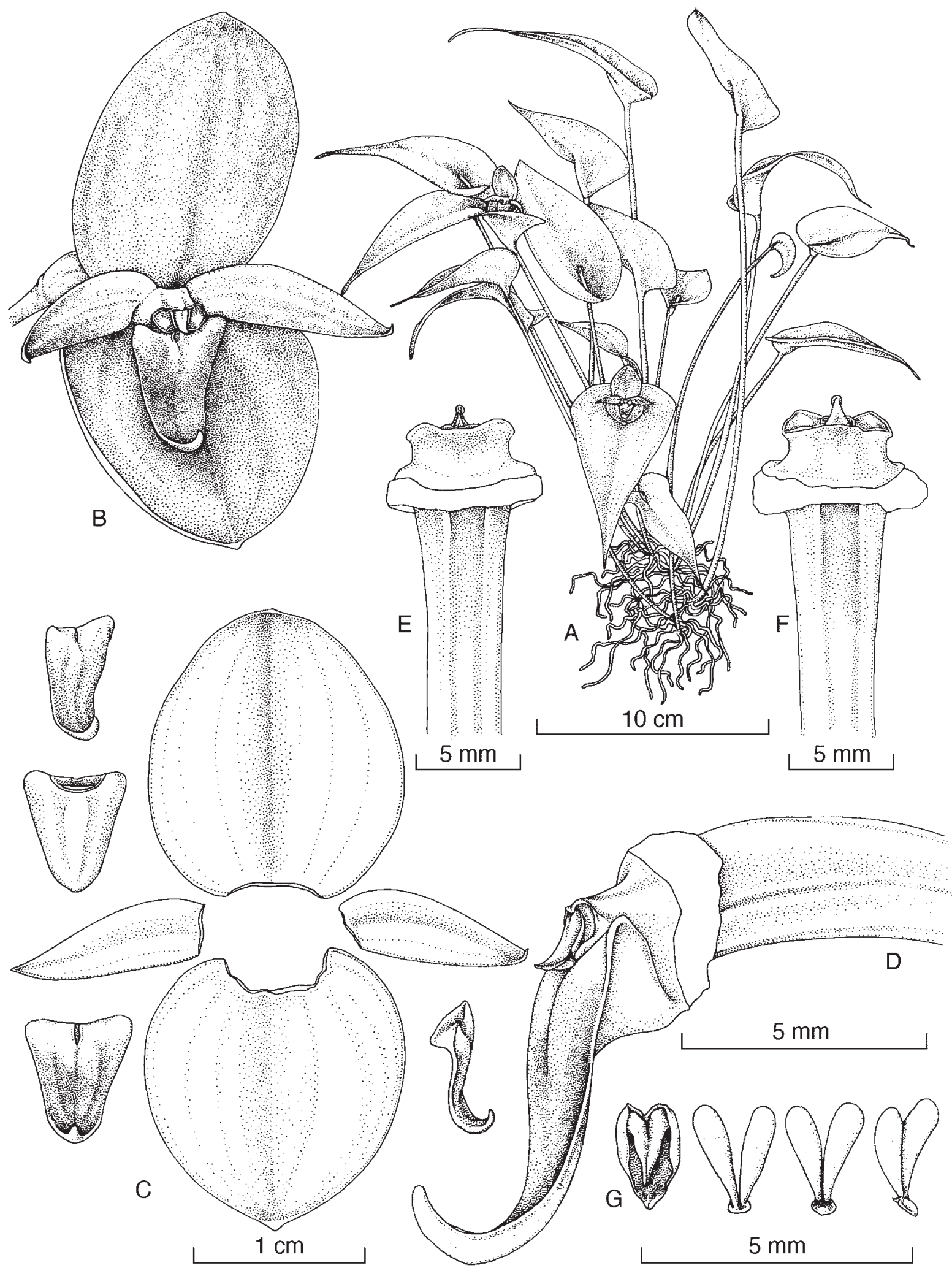

FIGURE 32. Pleurothallis oncoglossa Luer. A, habit; B, flower; $\mathbf{C}$, dissected perianth (the lip in three-quarter, abaxial, adaxial and lateral views); D, apex of ovary, column, and lip in lateral view; E, column, dorsal view; F, column, ventral view; G, anther cap and pollinarium (three views). Drawn by S. Díaz Poltronieri from Bogarín 5686 (JBL). 
$9^{\circ} 22^{\prime} 20.3^{\prime \prime} \mathrm{N}, \quad 83^{\circ} 35^{\prime} 01.8^{\prime \prime} \mathrm{W}, 1261 \mathrm{~m}$, bosque pluvial premontano, en bosque secundario remanente a orillas del río, 28 Julio 2009, D. Bogarín 7355 \& F. Pupulin (Holotype: JBL; Isotype: JBL). Fig. 33-34 (Vouchers, Bogarín 7355, Bogarín 7455, JBL).

Epiphytic, caespitose, erect to suberect, large herb to $50 \mathrm{~cm}$ tall. Roots slender, flexuous, ca. $1.5 \mathrm{~mm}$ in diam. Ramicauls terete, slender, 29.0-43.5 cm long, 2.5-4.0 mm in diam., yellowish green, provided with a tubular, short, truncate sheath to $3.5-4.0 \mathrm{~cm}$ long at the base, and a longer, tubular, tightly adpressed, truncate sheath below the middle, to $4-6 \mathrm{~cm}$ long, the bracts glumaceous, pale green when young, becoming brown, dry-papyraceous with age. Leaf borne horizontally at the apex of the ramicaul, becoming subpendent with age, thinly coriaceous, flexible, sessile, ovate, acute to acuminate, 16-19 × 7.5-8.0 cm, deeply cordate, forming 2 slightly imbricate lobes at the base, grass green, matte. Inflorescence a solitary flower, usually produced singly, rarely in pairs, from a reclined spathaceous bract 10-15 mm long, brown, dry-papyraceous when mature, eventually dissolving with age. Pedicel terete, pale green, 22-26 mm long. Ovary clavate, rounded in section, 4-8 mm long. Flowers solid dark purple with pale yellow tips on sepals, petals and lip, with distinct temporary activity, short-lived (usually 5, rarely 6, days). Dorsal sepal broadly ovate, subacute, 14-18 × 11-19 mm, 9- to 11-veined. Lateral sepals connate into a broadly ovate-subrounded, subacute synsepal, 11-20 × 15-20 mm, 9- to 11-veined. Petals subfalcate, acute, $14 \times 3.5 \mathrm{~mm}, 3$ - to 5-veined. Lip unguiculate, hinged to the column foot, triangular, basally truncate with rounded angles, acuminate, 9-10 × 5-6 mm, strongly conduplicate at the base, apex with the margin finely pubescent; glenion deeply recessed between the basal lobes of the lip, ca. $1.2 \mathrm{~mm}$ long. Column short, transversely subrectangular, dorsiventrally complanate, ca. $1.3 \times 4.0$ $\mathrm{mm}$, the anther apical, bent, the stigma apical, bilobed. Anther cap obtriangular, acute, bilobed at the base, 2-celled, ca. $1.8 \times 1.2 \mathrm{~mm}$. Pollinia 2 , narrowly oblong-pyriform, 2 $\mathrm{mm}$ long, attached to an elliptic viscidium through a short, cylindric caudicula. Fruit not seen. Fig. 31C.

Etymology: from the Greek words oxoteıvós (skotinós),

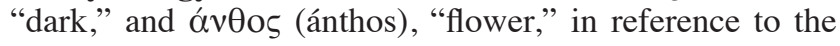
solid, dark-purple flower of the species, uncommon in this group.

Distribution: exclusively known from the Cordillera Volcánica Central y Cordillera de Talamanca in Costa Rica, at $1200-2000 \mathrm{~m}$ in elevation.

Ecology: an epiphyte of wet premontane and lower montane forests, at mid-elevations on the Pacific watershed of both the Central and the Talamanca Cordilleras, $P$. scotinantha is associated with forest remnants close to riverbanks, forest edges, or isolated trees in pastures. Flowering, both in the field and in cultivation, has been recorded from May to July, and November to January.

Distinguishing features: the dark purple, blackish, glossy color of the flower and the triangular, flat, dark-purple lip fading into a small white region toward the apex, whitish on the underside, are useful characters to distinguish it from its closest relative, $P$. oncoglossa, which has light purple-red flowers on a greenish-yellow background, the sepals fading yellow green toward the base, and a characteristic, callose hook at the apex of the lip.

Costa Rican material examined: Alajuela: Carrizal, Concordia, entre Los Cartagos y Cinco Esquinas, $10^{\circ} 08^{\prime} 16.8^{\prime \prime} \mathrm{N}, 84^{\circ} 09^{\prime} 49.8^{\prime \prime} \mathrm{W}, 2027 \mathrm{~m}, 2027 \mathrm{~m}$, bosque pluvial montano bajo, en potreros arbolados y bosque secundario, 17 junio 2009, floreció en cultivo en el Jardín Botánico Lankester, 8 enero 2010, D. Bogarín 7455, R. L. Dressler, F. Pupulin \& R. Trejos (JBL). San José: Pérez Zeledón, Cajón, Montecarlo, $3.5 \mathrm{~km}$ al noreste de Montecarlo, orillas del Río Peña Blanquita, 9²2'20.3"N, $83^{\circ} 35^{\prime} 01.8^{\prime \prime} \mathrm{W}, 1261 \mathrm{~m}$, bosque pluvial premontano, en bosque secundario remanente a orillas del río, 28 julio 2009 , D. Bogarín 7355 \& F. Pupulin (JBL). Map 3.

15. Pleurothallis tapantiensis Pupulin, M. Díaz \& Pridgeon, Vanishing Beauty. Vol. 2: 853-855. TYPE: Costa Rica. Cartago: Paraíso, Orosi, Tapantí, Parque Nacional Tapantí, Sendero Oropéndola, orillas del Río Grande de Orosi, 944'13.5"N, 8346'49.6"W, 1376 m, epífitas en sitio sombreado en bosque secundario alrededor del sendero, bosque pluvial premontano, 11 diciembre 2014, D. Bogarín 11273, M. Fernández, L. Taylor \& J. Sharma (Holotype: JBL). Fig. 35 (Voucher, Bogarín 11273, JBL).

Epiphytic, caespitose, erect to suberect, large herb to $23 \mathrm{~cm}$ tall. Roots slender, flexuous, ca. $1 \mathrm{~mm}$ in diam. Ramicauls terete, slender, 15-22 cm long, 0.15-0.20 cm in diam., yellowish green, provided with 2 basal, tubular, obtuse sheaths $1.7-6.0 \mathrm{~cm}$ long, the bracts glumaceous, pale green with minute purple warts when young, becoming brown, dry-papyraceous with age. Leaf borne horizontally at the apex of the ramicaul, becoming curved-subpendent with age, thinly coriaceous, flexible, sessile, ovate, narrowly acute, acuminate, $7.3-11.7 \times 4.5-5.5 \mathrm{~cm}$, deeply cordate at the base, grass green, matte. Inflorescence a solitary flower, from a reclined, rectangular, acute, spathaceous bract to 1.7 cm long, brown, dry-papyraceous when mature, eventually dissolving with age. Pedicel terete, green, 8-12 mm long. Ovary terete-subclavate, curved, rounded in section, 3-5 $\mathrm{mm}$ long. Flowers spreading, with distinct temporary activity, short-lived (to 5 days), the sepals reflexed, solid purple. Dorsal sepal erect, ovate, obtuse, 10-11 × 7.0-7.5 $\mathrm{mm}, 7$ - to 9 -veined. Lateral sepals connate into a broadly ovate, obtuse synsepal, 9.0-9.5 × 8.0-8.5 mm when spread, 9- to 11-veined. Petals narrowly triangular-subfalcate, acute, 6.0-7.0 × 0.9-1.1 mm, 3-veined. Lip unguiculate, hinged to the column foot, peltate, basally truncate with rounded angles, obtuse, with the apex slightly infolded, 6-7 $\times 3.0-3.5 \mathrm{~mm}$, conduplicate at the base, the apical margins thickened; glenion recessed between the thickened basal lobes of the lip, ca. $0.8 \mathrm{~mm}$ long. Column short, transversely subrectangular, dorsiventrally complanate, ca. $1.2 \times 2.5$ $\mathrm{mm}$, the anther apical, bent, the stigma apical, bilobed. Anther cap obtriangular, acute, bilobed at the base, 2-celled, ca. $0.5 \times 0.3 \mathrm{~mm}$. Pollinia 2 , narrowly oblong-pyriform, 0.5 $\mathrm{mm}$ long, attached to an elliptic viscidium through a short, cylindric caudicula. Fig. 31D.

Etymology: named after the Tapantí National Park, in the northern region of the Cordillera de Talamanca where the species was originally found. In the indigenous Cabécar 


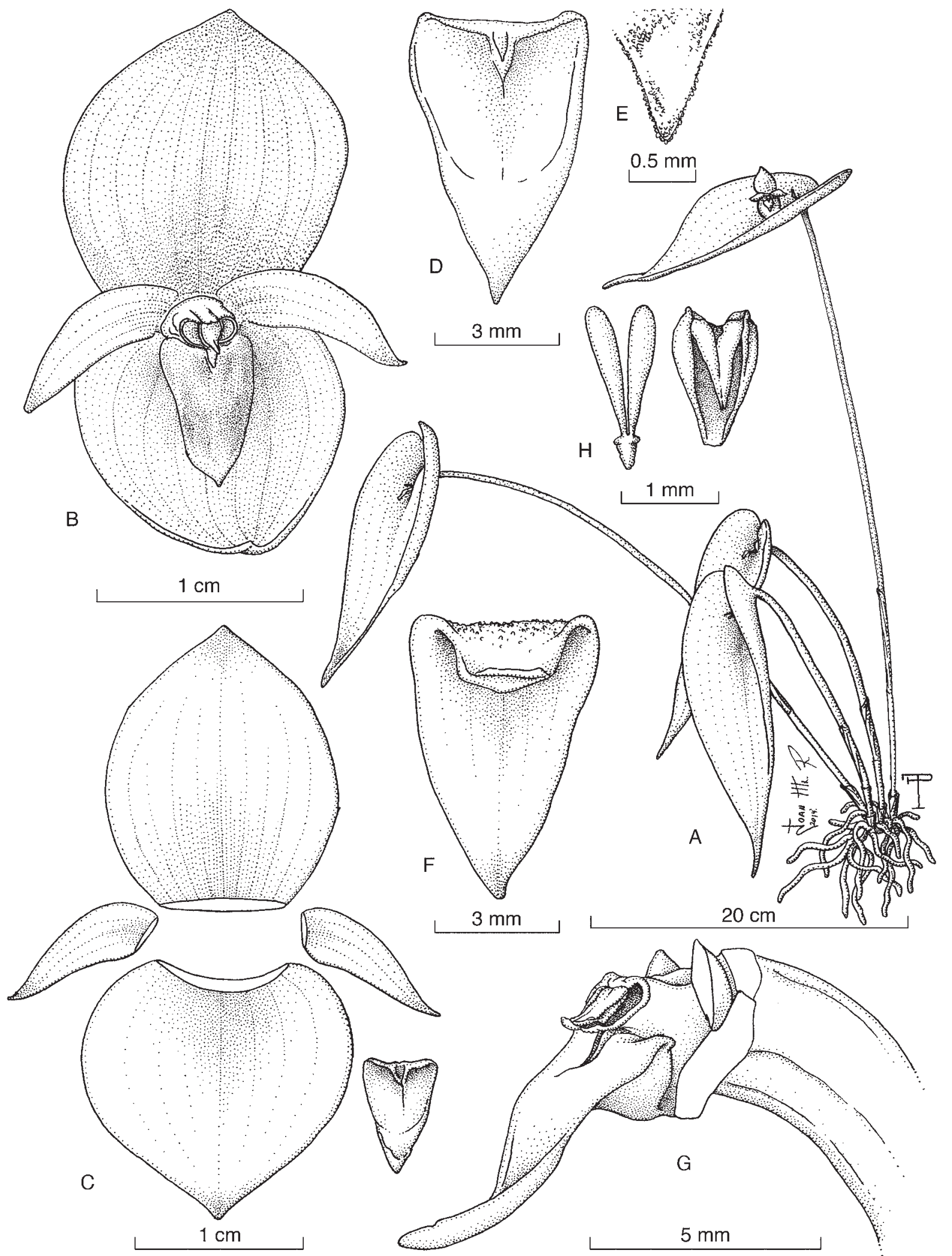

Figure 33. Pleurothallis scotinantha Pupulin, J. Aguilar \& M. Díaz. A, habit; B, flower; C, dissected perianth; D, lip, adaxial view; $\mathbf{E}$, detail of the lip apex; F, lip, abaxial view; $\mathbf{G}$, apex of ovary, column, and lip in lateral view; $\mathbf{H}$, pollinarium and anther cap. Drawn by J. M. Ramírez from Bogarín 7355 (JBL). Reproduced with permission from the Editor of Lankesteriana. 

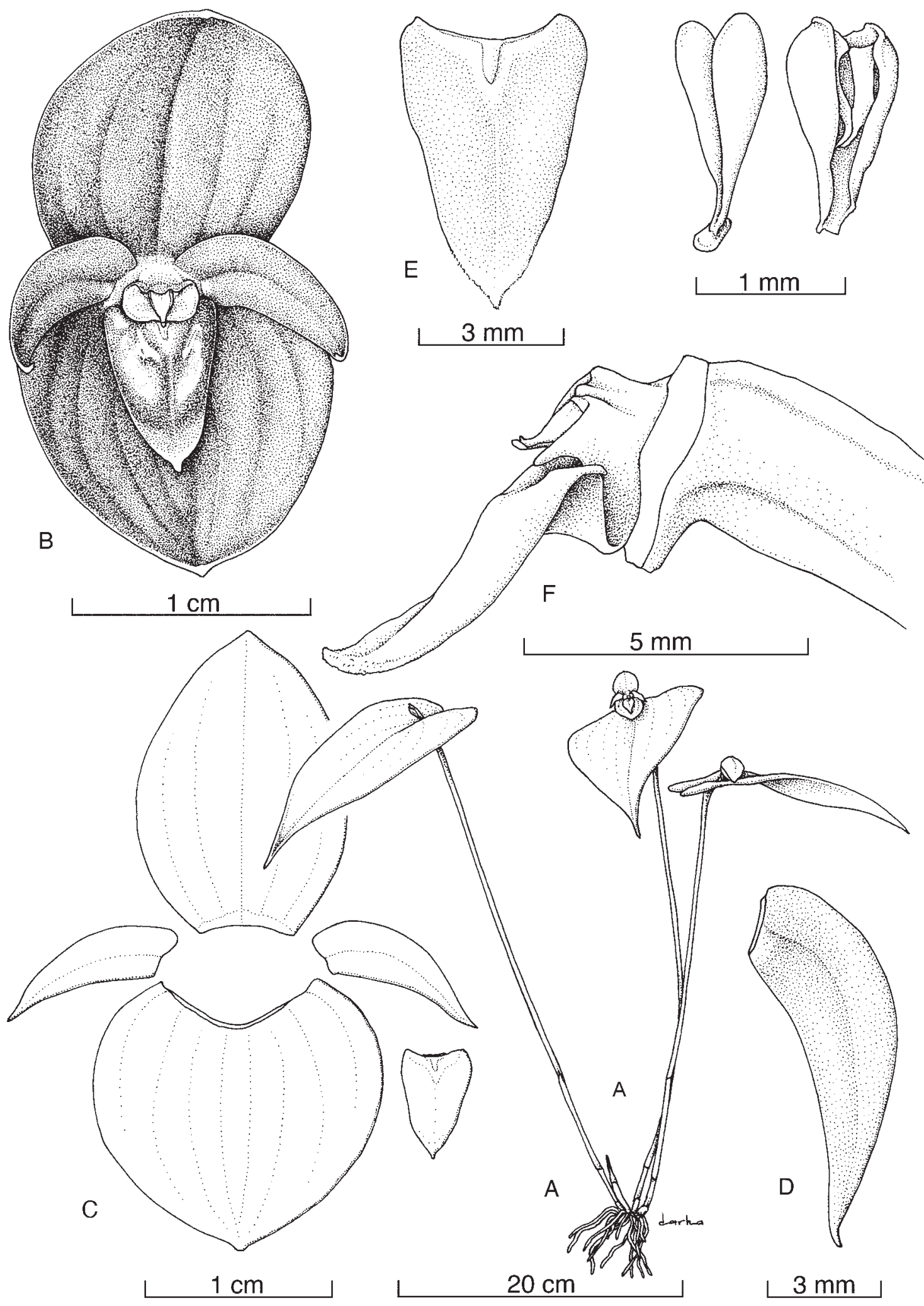

FIgURE 34. Pleurothallis scotinantha Pupulin, J. Aguilar \& M. Díaz. A, habit; B, flower; C, dissected perianth; D, left petal; E, lip, adaxial view; F, apex of ovary, column, and lip in lateral view; G, pollinarium and anther cap. Drawn by F. Pupulin and D. Solano Ulate from Bogarín 7455 (JBL). 


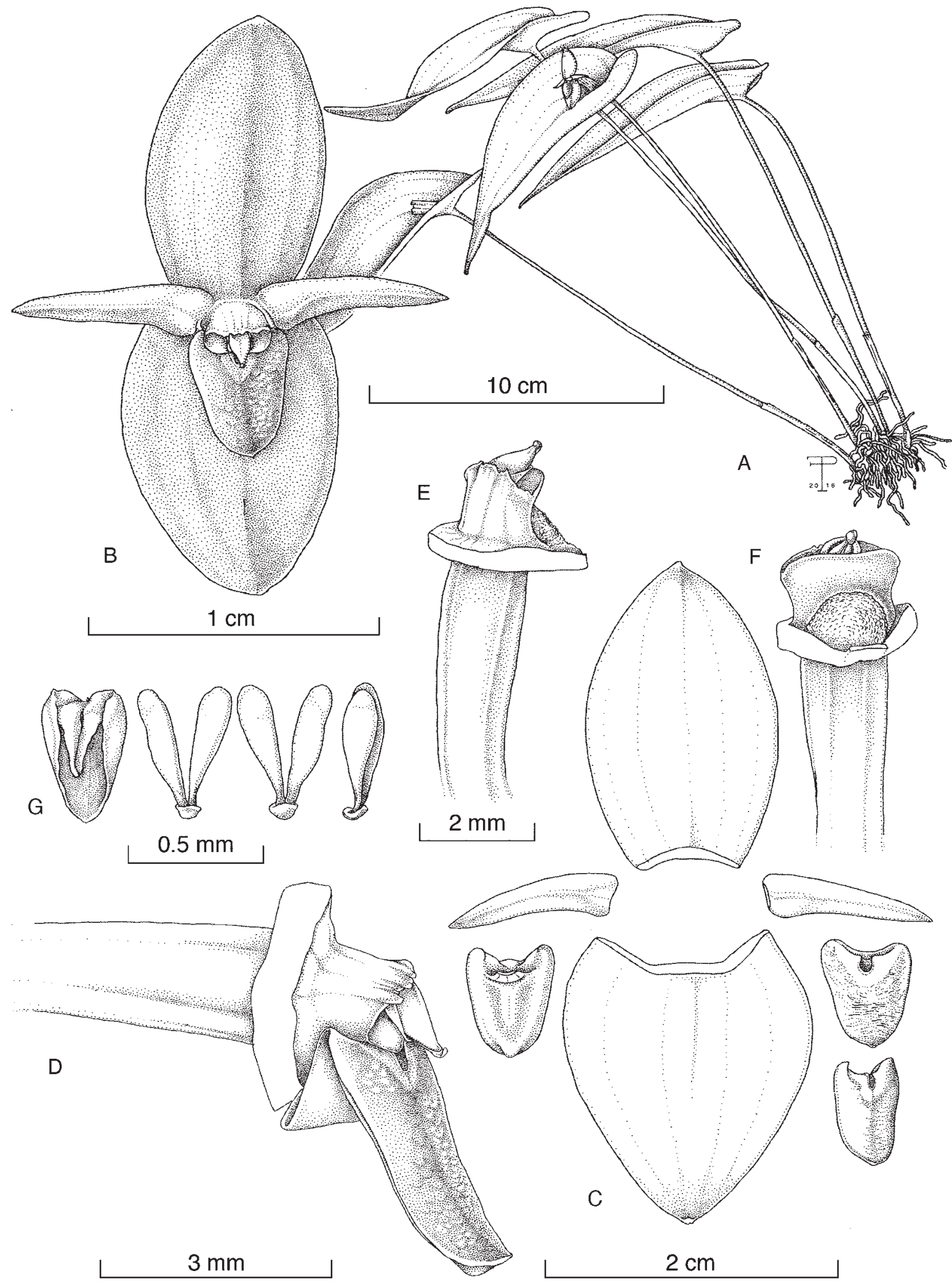

FIgURe 35. Pleurothallis tapantiensis Pupulin, M. Díaz \& Pridgeon. A, habit; B, flower; C, dissected perianth (the lip in abaxial, adaxial, and three quarters views); D, apex of ovary, column, and lip in lateral view; E, column, three-quarter view; F, column, ventral view; G, anther cap and pollinarium (three views). Drawn by F. Pupulin and S. Díaz Poltronieri from Bogarín 11273 (JBL). From Pupulin, 2020. 
language, the word tapantí has several meanings, mostly related to water: "clear water," "a zone of many waters," "torrent from the heavens."

Distribution: known only from Costa Rica.

Ecology: epiphytic in premontane wet forest on the Caribbean slopes of the Cordillera de Talamanca, Costa Rica, where populations have been found in damp and shady places at elevations between 1300 and $1800 \mathrm{~m}$. Flowering in cultivation has been recorded at least in March.

Distinguishing features: among the species of Pleurothallis close to $P$. cardiothallis provided with a peltate lip, which besides $P$. cardiothallis also includes in Costa Rica P. navisepala. Pleurothallis tapantiensis may be easily recognized by the lip that is glabrous and concolorous purple underneath (vs. papillose, whitish), with the apical margins straight (vs. involute, forming a pseudoapicule), provided for all its length with thin, irregular, transverse grooves.

Like most other species in this group, the flowers of Pleurothallis tapantiensis are temporarily active, likely in response to the levels of light and environmental humidity (Pupulin, Díaz-Morales, Aguilar, et al., 2017). The flowers open early in the morning and usually remain fully spread until noon, when the petals incurve and the lateral sepals lose turgor and fold over each other. The process repeats for 4 to 6 days, after which the flower fades and detaches from the pedicel.

Costa Rican material examined: Cartago: Paraíso, Orosi, Tapantí, Parque Nacional Tapantí, Sendero Oropéndola, orillas del Río Grande de Orosi, 944'13.5"N, 8346'49.6"W, $1376 \mathrm{~m}$, epífitas en sitio sombreado en bosque secundario alrededor del sendero, bosque pluvial premontano, 11 diciembre 2014, D. Bogarín 11273, M. Fernández, L. Taylor \& J. Sharma (Holotype: JBL). Cartago, San Francisco, Muñeco, Navarro, ca. $5 \mathrm{~km}$ south of the Navarro church, between Río Sombrero and Quebrada Patarrá, road to Alto Belén, 945'38.28"N, 8353'56.81"W, 1808 m, 3 Feb. 2017, flowered in cultivation at Lankester Botanical Garden,31 Jan 2018,D.Bogarín 12228, M.Cedeño, M. Fernández \& E. Kaes (JBL). Cartago, Aguacaliente, Navarro de Muñeco, 946'18.00"N, 8354'08.40"W, 1526 $\mathrm{m}$, bosque muy húmedo montano bajo, 13 Jul 2018, M. Díaz 331, M. Fernández \& D. Villalobos (JBL). Map 3.

\section{The P.phyllocardia group}

16. Pleurothallis adventurae Karremans \& Bogarín, Orchideen J. 18(3): 112. 2011. TYPE: Costa Rica. Puntarenas: Coto Brus, Sabalito, Zona Protectora Las Tablas, $13 \mathrm{~km}$ al noreste de Lucha, Sitio Coto Brus, entre Río Surá y Quebrada Sutú, Finca de Miguel Sandí, 856'46.1"N, $82^{\circ} 44^{\prime} 30.9^{\prime \prime} \mathrm{W}, 1778 \mathrm{~m}$, bosque pluvial montano bajo, epífitas en potreros arbolados, 6 junio 2010, D. Bogarín 7696 \& A. Karremans (Holotype: CR; Isotypes: JBL-spirit, USJ). Fig. 36 (Voucher, Bogarín 7696, CR).

Epiphytic, caespitose, erect to suberect herb to $25 \mathrm{~cm}$ tall. Roots slender, flexuous, white, ca. $1 \mathrm{~mm}$ in diam. Ramicauls terete, slender, to $25 \mathrm{~cm}$ long, pale green, provided with 3-4 tubular, dry-papyraceous, brown sheaths in the basal third of the stem, the uppermost tightly clasping, 2.0-2.5 $\mathrm{cm}$ long. Leaf borne at the apex of the ramicaul, hanging, almost parallel to the stem, thinly coriaceous, flexible, narrowly lanceolate, acute, the margins frequently revolute, 8-12 $\times 2-3 \mathrm{~cm}$, deeply cordate at the base, the basal lobes not overlapping, grayish-green, matte. Inflorescence fasciculate, with solitary flower borne in succession from a reclined, rectangular, truncate, spathaceous, drypapyraceous, grayish-brown bract to $1.2 \mathrm{~cm}$ long. Pedicel terete, green, to $2 \mathrm{~cm}$ long. Ovary terete, $2 \mathrm{~mm}$ long. Flowers spreading, resupinate, the sepals purple red, the petals and lip dark purple, pubescent-tomentose. Dorsal sepal erect, elliptic, acute, $6.5-7.0 \times 4.5-5.0 \mathrm{~mm}, 3$-veined, pubescenttomentose, more densely so toward the apex. Lateral sepals connate into an ovate-orbicular, subacute synsepal, pubescent-tomentose, 5.7-5.9 × 5.0-5.2 mm, 4-veined. Petals narrowly oblong, acute, denticulate, 5.6-5.7 × 1.2$1.3 \mathrm{~mm}, 1$-veined. Lip unguiculate, hinged to the column foot, strongly geniculate at the base, triangular, basally truncate with obtuse angles, acute, minutely apiculate, the margins glandulose, the basal margins erect, 2.7-2.8 $\times$ 2.2-2.3 mm, papillose; glenion raised on a thick callus on the disc ca. $0.8 \mathrm{~mm}$ long. Column short, stout, transversely subrectangular, dorsiventrally complanate, ca. $1.2 \times 1.0 \mathrm{~mm}$, the anther apical, incumbent, the stigma apical, bilobed. Anther cap cucullate, ovate, truncate, 2-celled, ca. $0.8 \times 0.5$ $\mathrm{mm}$. Pollinia 2, ovate-pyriform, $0.8 \mathrm{~mm}$ long, attached to an orbicular viscidium. Fruit not seen. Fig. 31E.

Etymology: from the Latin adventura, adventure, in reference to the adventurous circumstances under which the type plant was found.

Distribution: known only from southeastern Costa Rica but expected from nearby Panama as the type locality is less than $2 \mathrm{~km}$ from the boundary between the two countries.

Ecology: epiphytic in lower montane rain forest, in primary oak forest or on trees in pastures, at 1700-1800 $\mathrm{m}$ in elevation. Flowering has been recorded from June to December.

Distinguishing features: among Costa Rican specimens, Pleurothallis adventurae is easily distinguished by the grayish-green, matte leaves with revolute margins, and the purple-red flowers adaxially completely covered with short, stiff, pointed tubercles.

Notwithstanding its highly atypical morphological characteristics when studied in the framework of the Costa Rican flora, Pleurothallis adventurae surely belongs morphologically to the $P$. phyllocardia group. The apparent deviancy of this species with respect to the other taxa of the group is, in fact, just an artifact of the strictly local species sample targeted in this study. When a broader view of the group is adopted, including the highest species diversity shown in the northern Andes, it is evident that the $P$. phyllocardia group blends, via $P$. peculiaris Luer/P. cardiostola Rchb.f./P. lilijae Foldats, into the group of $P$. dibolia Luer/P. diabolica Luer \& R. Escobar/P. portillae Luer, with both erect and supine spathes. More strictly, the affinities of $P$. adventurae are with a small group of mostly South American species that exhibit glaucous, dark green, flexible, usually long, narrowly lanceolate and deeply cordate leaves with revolute margins, provided with dark red-purple flowers often presenting scabrous to hirsute indumenta. It is most closely related to the Ecuadorian 

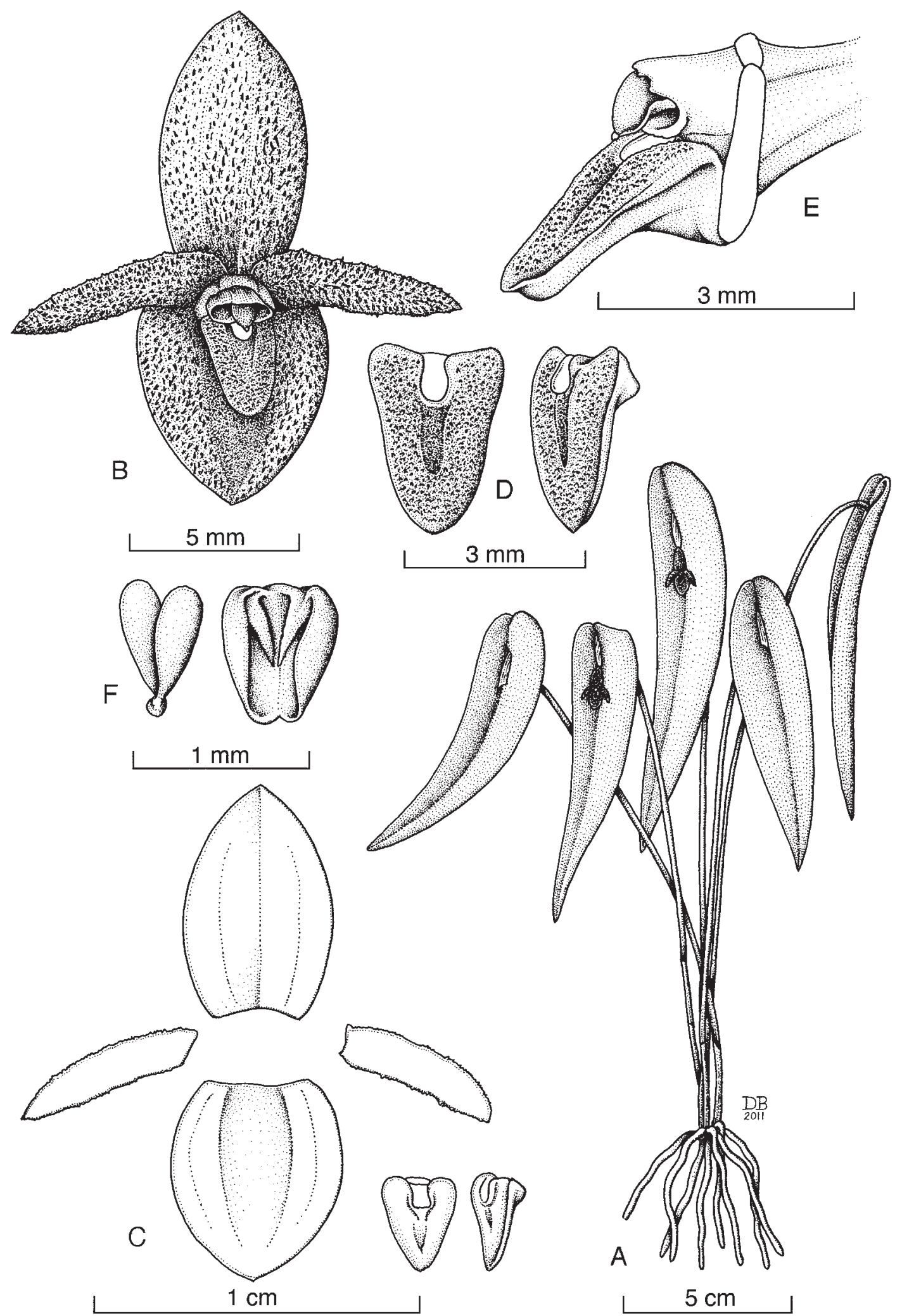

FIGURE 36. Pleurothallis adventurae Karremans \& Bogarín. A, habit; B, flower; C, dissected perianth; D, lip in adaxial and three-quarter views; E, apex of ovary, column, and lip in lateral view; F, pollinarium and anther cap. Drawn by D. Bogarín from Bogarín 7696 (CR). 
P. portillae, from which it can be distinguished by the shape of the leaf, the color and indumentum of the flowers, and the width of the petals. It also resembles $P$. calamifolia Luer \& R. Escobar, P. omoglossa Luer and P. sigynes Luer. In Costa Rica, it is known exclusively from the southern, Pacific extension of the Cordillera de Talamanca, close to the border with Panama, where the species must be also expected.

Costa Rican material examined: Puntarenas: Coto Brus, Sabalito, Zona Protectora Las Tablas, 13 km NE of Lucha, Sitio Coto Brus, finca Sandí "El Capricho," epiphytic on Quercus sp. in pastures and along the river Sutú, wet premontane forest, $8^{\circ} 56^{\prime} 46.1^{\prime \prime} \mathrm{N}, 82^{\circ} 44^{\prime} 30.9^{\prime \prime} \mathrm{W}$, 1778 m, 6 oct. 2010, F. Pupulin 7904, D. Bogarín, R. L. Dressler \& M. Fernández. (JBL); Zona Protectora Las Tablas, $13 \mathrm{~km}$ al noreste de Lucha, Sitio Coto Brus, entre Río Surá y Quebrada Sutú, Finca de Miguel Sandí, $8^{\circ} 56^{\prime} 46.1^{\prime \prime} \mathrm{N}, \quad 82^{\circ} 44^{\prime} 30.9^{\prime \prime} \mathrm{W}, 1778 \mathrm{~m}$, bosque pluvial montano bajo, epífitas en potreros arbolados, 6 junio 2010 , D. Bogarín 7697 \& A. Karremans (JBL); Zona Protectora Las Tablas, $13 \mathrm{~km}$ al noreste de Lucha, Sitio Coto Brus, Finca de Miguel Sandí, "ad ager Sandiorum 'El Capricho,' supra arbores praecipue quercinis in collibus montibusque et ad margines pascuibus inter flumen Sutú," bosque muy húmedo premontano, $8^{\circ} 56^{\prime} 46.1^{\prime \prime} \mathrm{N}, 82^{\circ} 44^{\prime} 30.9^{\prime \prime} \mathrm{W}, 1780 \mathrm{~m}$, 6 Oct. 2010, D. Bogarín 8093, R. L. Dressler, M. Fernández. \& F. Pupulin (JBL); same locality, 6 Oct. 2011, D. Bogarín
9253, R. L. Dressler, M. Fernández (JBL); Zona Protectora Las Tablas, $13 \mathrm{~km}$ al noreste de Lucha, Sitio Coto Brus, entre Río Surá y Quebrada Sutú, Finca de Miguel Sandí, $8^{\circ} 56^{\prime} 46.1^{\prime \prime} \mathrm{N}, 82^{\circ} 44^{\prime} 30.9^{\prime \prime} \mathrm{W}, 1778 \mathrm{~m}$, bosque pluvial montano bajo, epífitas en potreros arbolados, $10 \mathrm{dec}$. 2013, A. Karremans 6125, D. Bogarín, M. Fernández \& L. Sandoval (JBL). Map 4.

17. Pleurothallis anthurioides A. Doucette, Orquideología 33(2): 126. 2016. TYPE. Panama. Bocas del Toro: Culebra, 800 m.a.s.l., flowered in cultivation at Finca Dracula, Guadalupe, Panama, 11 Jan 2012, A. Doucette 3998 (Holotype: PMA). Fig. 37 (Voucher, Bogarín 10649, JBL).

Epiphytic, caespitose, large erect herb to $30 \mathrm{~cm}$ tall. Roots slender, flexuous, ca. $1 \mathrm{~mm}$ in diam. Ramicauls terete, slender, 16-30 cm long, 0.3-0.4 cm in diam., pale green, provided with 2-3 basal, tubular, obtuse sheaths of different sizes, to $7 \mathrm{~cm}$ long, dry-papyraceous, brown when mature. Leaf borne at the apex of the ramicaul, held horizontally to facing down ca. $45^{\circ}$, thinly coriaceous, flexible, sessile, ovate, tridenticulate, $7-11 \times 3.8-7.0 \mathrm{~cm}$, deeply cordate at the base, green, matte. Inflorescence fasciculate, of several solitary flowers produced in succession from an erect, rectangular-subclavate, truncate, spathaceous bract to $2 \mathrm{~cm}$ long, glumaceous, green, becoming brown, dry-papyraceous when mature. Pedicel terete, green, subgeniculate at the

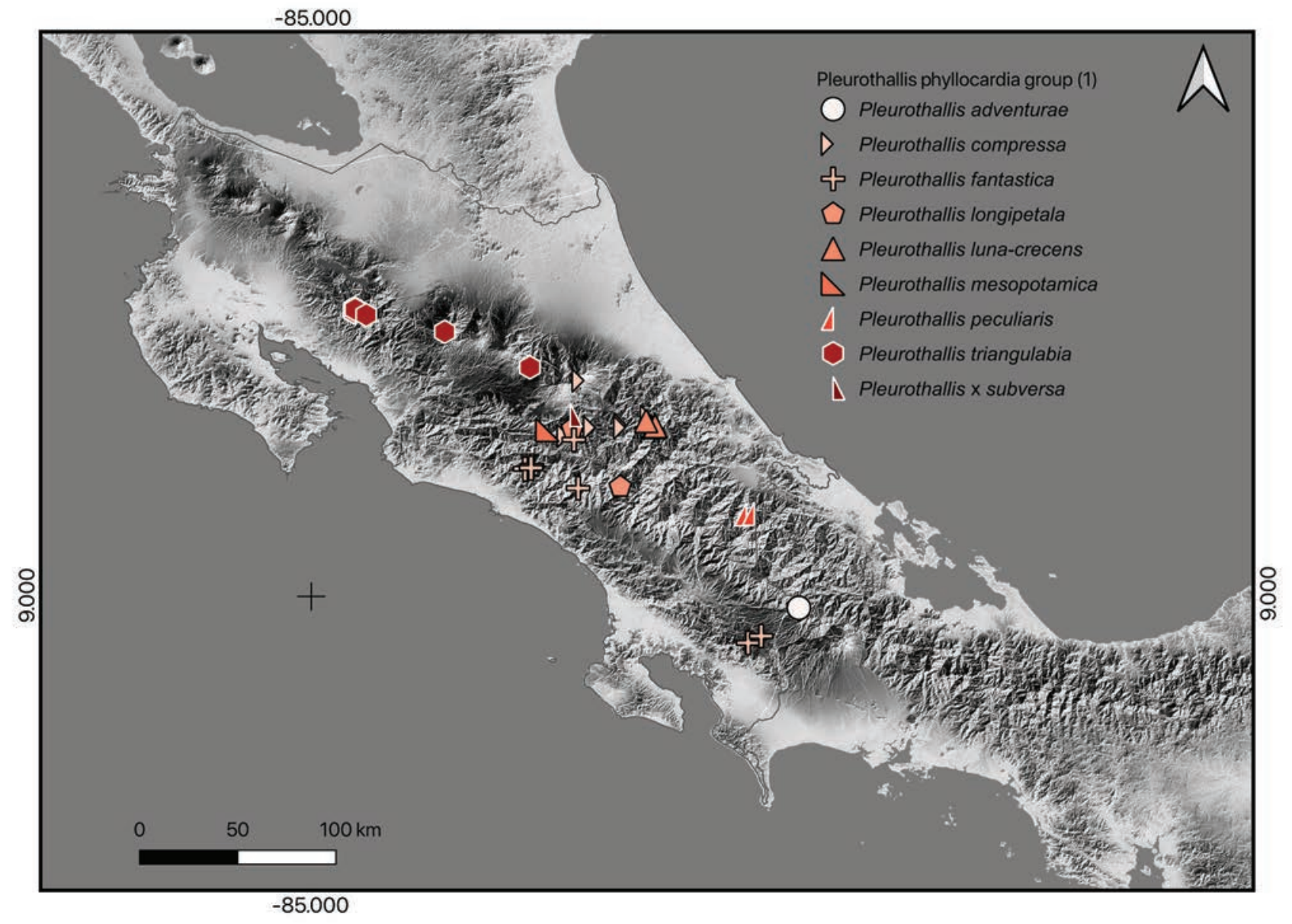

MAP 4. Map of collection sites for the species of Pleurothallis phyllocardia group. 


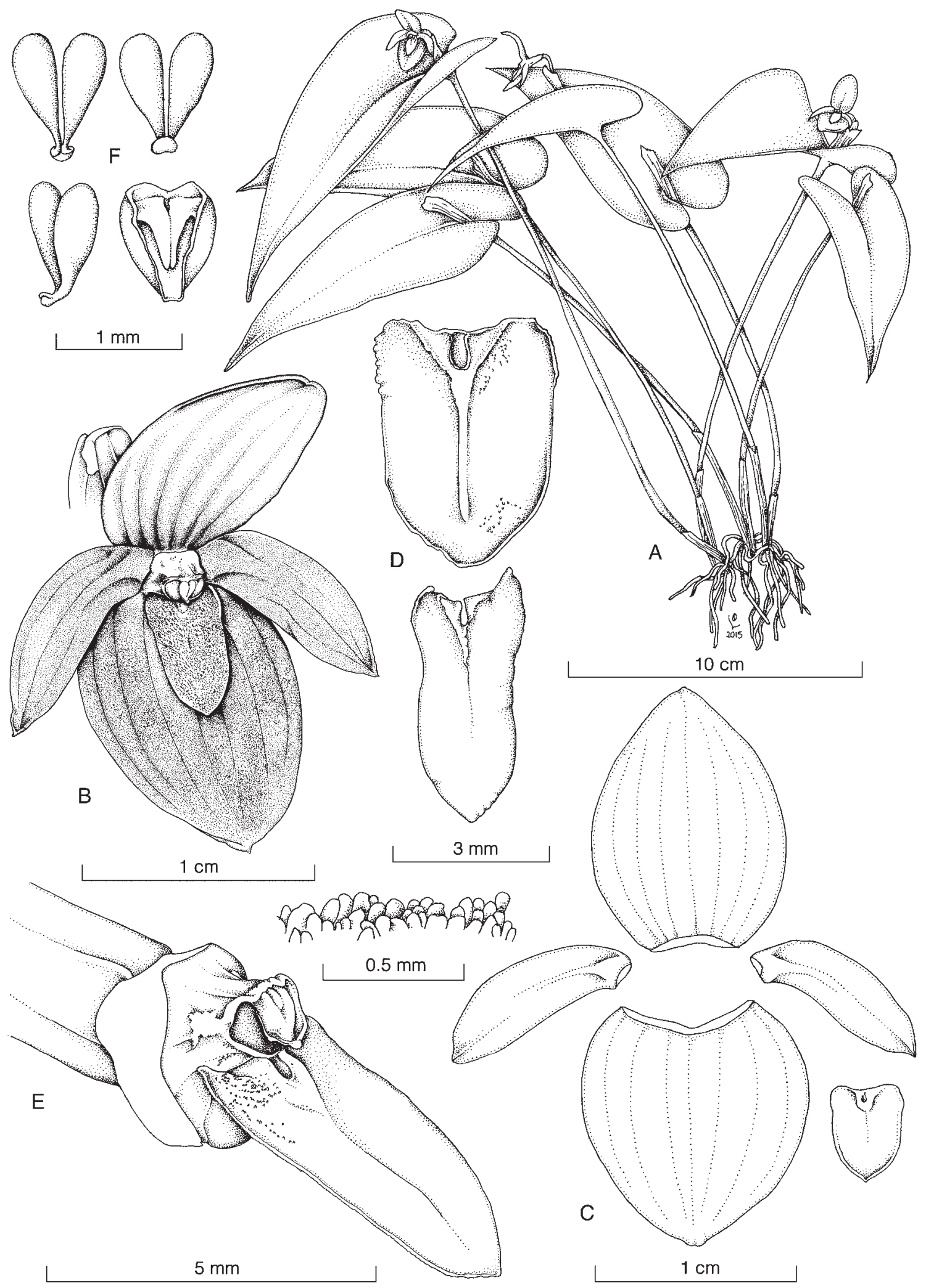

FIgURE 37. Pleurothallis anthurioides A. Doucette. A, habit; B, flower; $\mathbf{C}$, dissected perianth; D, lip in adaxial and three-quarter views; $\mathbf{E}$, apex of ovary, column, and lip in three-quarter view; F, pollinarium (three views) and anther cap. Drawn by L. Oses from Bogarín 10649 (JBL). 
joining point with the ovary, to $2 \mathrm{~cm}$ long. Ovary teretesubclavate, ca. $5 \mathrm{~mm}$ long. Flowers spreading, resupinate, with the dorsal sepal yellow, blotched with purple at the base and striated along the veins, the synsepal suffused with purple on a yellow background, the petals purple with yellow margins, the lip dark vinaceous purple. Dorsal sepal slightly reclined, broadly ovate-elliptic, acute, 15-19 $\times$ 8-10 mm, 7-veined. Lateral sepals connate into a broadly ovate-suborbicular, obtuse, slightly concave synsepal, 12-18 × 10-12 mm, 7-veined. Petals oblong, subfalcate, inserted at $45^{\circ}$, acute, ciliate, 10-13 × 3-4 mm, 1-veined, the vein body thickened at the base forming a low keel. Lip oblong-peltate, thick, hinged to the column foot, basally concave, truncate-emarginate with rounded angles, obtuse, 5-6 $\times 3-4 \mathrm{~mm}$, rugulose adaxially; glenion raised on a thick callus on the disc ca. $0.5 \mathrm{~mm}$ long. Column short, stout, conical, dorsiventrally compressed, ca. $2 \times 3 \mathrm{~mm}$, with a distinct foot, the anther apical, incumbent, the stigma apical, bilobed. Anther cap cucullate, ovate, 2-celled, ca. $0.8 \times 0.6$ $\mathrm{mm}$. Pollinia 2, narrowly ovate, $0.8 \mathrm{~mm}$ long, attached to a rounded-subrheniform viscidium. Fig. $31 \mathrm{~F}$.

Etymology: named in allusion to the similarity of the vegetative shoots to the inflorescence of Anthurium species.

Distribution: known only from western Panama and southern Costa Rica.

Ecology: an epiphyte of the middle-elevation regions of southern Cordillera de Talamanca, where populations have been found on both the Caribbean (in Panama) and Pacific (in Costa Rica) watersheds of the chain. Phenological data are scanty, but the species apparently flowers at the beginning of the dry season in the region, with blooming specimens documented in the months of January and March.

Distinguishing features: the erect spathe and the comparatively large flowers, striped and suffused with dull purple on a yellow background with the lip dark vinaceous purple, concave sepals, and subfalcate, entire petals pointing downward and provided with a basal, callous keel, distinguish the species.

Florally, Pleurothallis anthurioides is superficially similar to species of the $P$. cardiothallis group, with large tepals and a slightly concave, bilabiate perianth, but the inflorescence is exerted from an erect bract and the lip of the flower is much more reminiscent, both in shape and indumentum, of those of species close to P. phillocardia. The comparatively very large petals, with a distinct, thickened keel at the base, held obliquely and pointing downward, are unique to $P$. anthurioides.

Costa Rican material examined: Puntarenas: Coto Brus, Sabalito, Zona Protectora Las Tablas, $15 \mathrm{~km}$ al noreste de Lucha, Sitio Tablas, Finca Sandí-Hartmann "El Capricho," camino a El Surá, 857'0.63"N, 8244'59.72"W, $2017 \mathrm{~m}$, bosque pluvial montano bajo, 10 diciembre 2013, D. Bogarín 10649, A. Karremans, M. Fernández \& L. Sandoval (Holotype: JBL). Map 5.

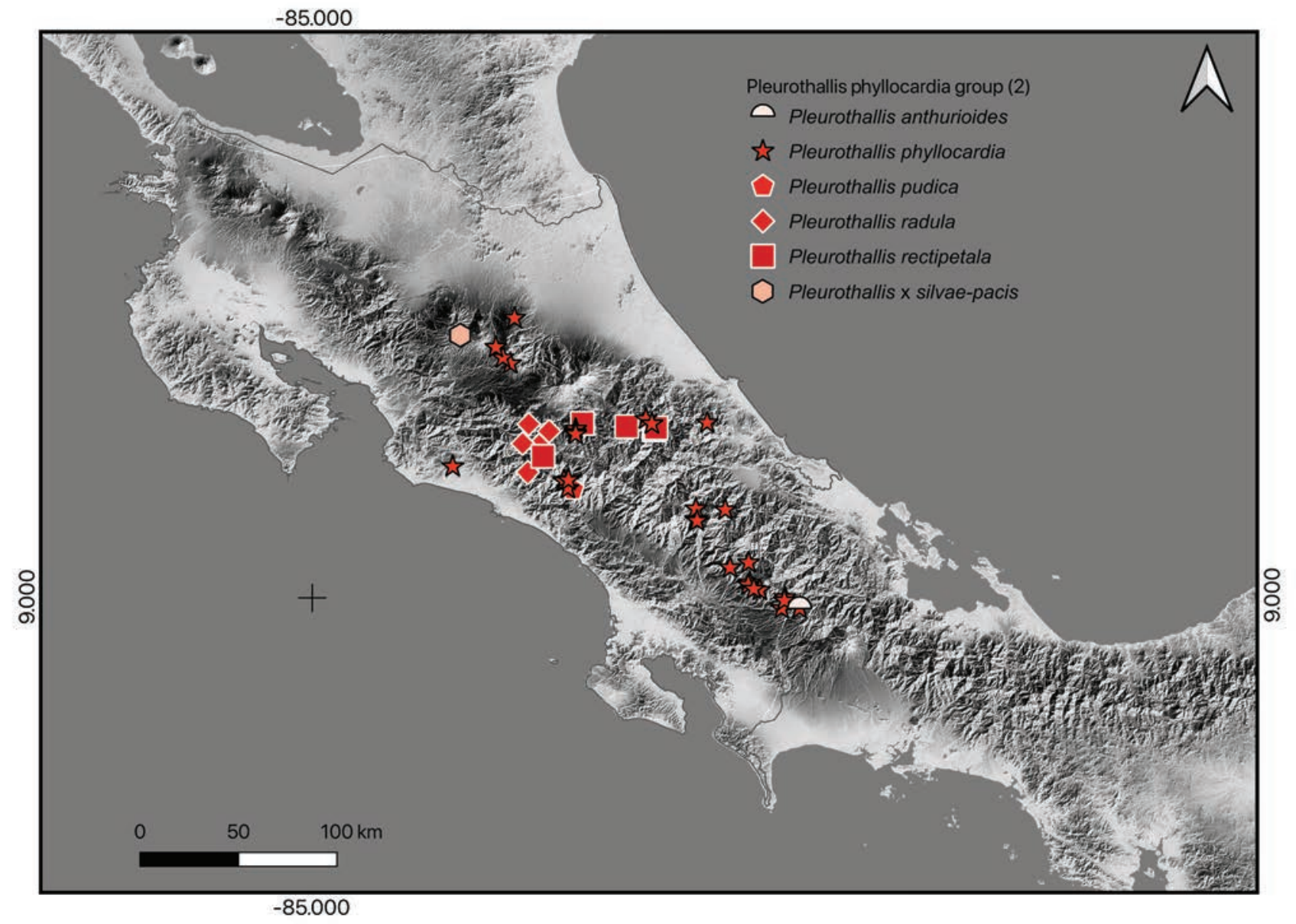

Map 5. Map of collection sites for the species of Pleurothallis phyllocardia group. 
18. Pleurothallis compressa Luer, Lindleyana 11(2): 75. 1996. Acronia compressa (Luer) Luer, Monogr. Syst. Bot. Missouri Bot. Gard. 103: 112. 2005. Zosterophyllanthos compressus (Luer) Szlach. \& Kulak, Richardiana 6(4): 188. 2006., as Z. compressa. TYPE: Costa Rica. Cartago: Turrialba, flowered in cultivation at the Lankester Botanical Garden, Cartago, 7 March 1995, peduncle flat, flower light brown, column white, C. Luer 17380 (Holotype: CR; Isotype: MO). Fig. 38 (Voucher, Bogarín 7839, JBL).

Epiphytic, caespitose, curved to pendent herb, to $30 \mathrm{~cm}$ tall. Roots slender, flexuous, 1-2 $\mathrm{mm}$ in diam. Ramicauls terete at the base becoming strongly ancipitous at apex, slender, 14-30 cm long, 2-5 $\mathrm{mm}$ in diam., yellowish green, provided with a tubular, short, truncate sheath to $2 \mathrm{~cm}$ long at the base, and a longer, tubular, tightly adpressed, truncate sheath below the middle, to $6 \mathrm{~cm}$ long, the bracts glumaceous, pale green when young, becoming brown, drypapyraceous with age. Leaf reclined, so the lower surface facing the pendent-curved stem, thinly coriaceous, flexible, sessile, narrowly lanceolate-ovate, acuminate, 11-18 × 4-6 $\mathrm{cm}$, deeply cordate at the base, the basal lobes adpressed but not overlapping, grass green, matte. Inflorescence a solitary flower, borne pendent from a suberect, spathaceous, diagonally truncate bract $10 \mathrm{~mm}$ long, brown, drypapyraceous when mature; peduncle terete, facing down, to $15 \mathrm{~mm}$ long. Pedicel terete, to $7 \mathrm{~mm}$ long. Ovary suclavate, curved rounded in section, reddish brown, 5-6 $\mathrm{mm}$ long. Flowers mostly nonresupinate, the sepals reddish brown, the petals light ocher-brown, the lip dull orange, the column white. Dorsal sepal ovate, acute, $6 \times 4 \mathrm{~mm}, 3$-veined.Lateral sepals connate into a subrounded, apically deeply excised synsepal, $6 \times 5 \mathrm{~mm}$, the apices free for $2 \mathrm{~mm}$, acute, abruptly apiculate, each half 2 -veined. Petals narrowly triangularfalcate, acuminate, $10 \times 1 \mathrm{~mm}, 1$-veined. Lip hinged to the column foot, broadly triangular-rheniform, basally truncate with rounded angles, broadly obtuse, apiculate, sparsely verrucose, $2 \times 3 \mathrm{~mm}$, strongly conduplicate at the base, the margins slightly reflexed; glenion raised on a cushion-like callus between the basal lobes of the lip, less than $1 \mathrm{~mm}$ long. Column short, transversely subrectangular, dorsiventrally complanate, ca. $2 \times 2 \mathrm{~mm}$, apically diagonally truncate seen from the side, the anther apical, bent, the stigma apical, bilobed. Anther cap cucullate, narrowly ovate-triangular, cordate, 2-celled. Pollinia 2, narrowly oblong-pyriform, attached to a peltate-subrounded viscidium through 2 short, cylindrical caudicles. Fig. 31G-H.

Etymology: from the Latin compressus, "compressed, flattened," in reference to the laterally compressed ramicaul.

Distribution: known only from Costa Rica, along the Caribbean watershed of the northern Cordillera de Talamanca.

Ecology: growing as an epiphyte in secondary forests and open areas of premontane pluvial forests along the Caribbean watershed of the Continental Divide, at 1150$1850 \mathrm{~m}$ in elevation. Blooming has been recorded in cultivation from October to February, and in July.

Distinguishing features: the curved to pendent plants, provided with ancipitous ramicauls, narrowly lanceolateovate, acuminate leaves deeply cordate at the base, and the small brown flower borne pendently beneath the leaf, completely reflexed (or laterally "compressed"), easily distinguish Pleurothallis compressa from any other species in the genus.

Costa Rican material examined: Cartago: Cartago, San Francisco, Muñeco, Finca Loma Verde y Jilguero, camino a Alto Belén, entre Río Sombrero y Quebrada Patarrá, 946'50.3"N, 8354'21.1"W, $1542 \mathrm{~m}$, bosque pluvial premontano, epífitas en bosque secundario y árboles en zonas abiertas, 22 Jul 2010, D. Bogarín 7839, M. Fernández, R. Trejos \& C. Smith (JBL). Paraíso. Orosi, Purisil, camino a Alto Jaular, entre los ríos Jaular y Purisil, Finca La Ponderosa, bosque muy húmedo premontano, epífitas en bosque secundario, 9 $44^{\prime} 13.9^{\prime \prime} \mathrm{N}, 83^{\circ} 48^{\prime} 26.9^{\prime \prime} \mathrm{W}$, 1606 m, 14 Oct 2008, D. Bogarín 5378, R. Gómez, R. Trejos \& J. Warner (JBL). Turrialba. Santa Cruz, Más o menos 4-5 $\mathrm{km}$ de la Iglesia de Santa Cruz, en el camino a las Abras, después de Calle Vargas, cerca de Buenos Aires, en el punto del cruce entre Las Abras, Calle Vargas y Las Virtudes, al lado de la calle en un potrero pantanoso, $9^{\circ} 59^{\prime} 32^{\prime \prime} \mathrm{N}$, 834' 13 "W, 1750-1850 m, 5 Aug 2008, A. P. Karremans 1370 \& Karremans (JBL). Turrialba, Torito, road to Santa Teresa, along a small creek, on insolate tree in pasture, 31 Jul 1999, flowered in cultivation at Jardín Botánico Lankester, 25 Feb 2000, F. Pupulin 962, R. L. Dressler, K. Dressler, D. E. Mora \& M. Retana (JBL). Turrialba, Moravia de Chirripó, hills north of Moravia across the plain with pasture, premontane wet forest, secondary mature vegetation and remnants of secondary vegetation in pastures, $9^{\circ} 50^{\prime} 18^{\prime \prime} \mathrm{N}, 83^{\circ} 26^{\prime} 45^{\prime \prime} \mathrm{W}, 1135 \mathrm{~m} 12$ Jun 2002 , flowered in cultivation at Jardín Botánico Lankester, 11 Oct 2005, F. Pupulin 3935, M. Bonilla, R. Gómez, H. León-Páez \& W. Schug (JBL). Turrialba, Tayutic, Moravia de Chirripó, 5 Kilómetros al oeste del centro de Moravia. Cerca de Tsipiri. Sobre sendero al lado de la calle que va a Platanillo, 949'28"N, 8325'16"W, $1220 \mathrm{~m}, 4$ Dec 2010, A. P. Karremans 1220 \& M. Contreras Fernández. (JBL). Turrialba. Valle del Reventazón, Jicotea, Finca La Pradera, 947'15"N, 8332'35"W, 1000 m, 22 Jun 1995, G. Rivera $2525 \&$ A. Rojas (CR). Turrialba, Tayutic, Finca La Pradera, Jicotea, 100-1200 m, 9.7875000, -83.5430556, 22 Jun 1995, G. Rivera 2512 (CR); same collecting data, $G$. Rivera 2519 (CR). Turrialba, Tayutic, Vereh. Siguiendo la fila entre Ríos Vereh y Jicotea, 9.7750000, -83.5444444, 26 Jul 1995, A. Cascante Marín 8126 \& G. Herrera (CR). Turrialba, en cultivo en el Jardín Botánico Lankester, legit C. Luer 17380, planta sobre la cual se basó la descripción original (clonotypus), 16 Jan 2004, D. Bogarín 642 (JBL). Without specific locality data: flowered in cultivation at Jardín Botánico Lankester, 11 Jun 2007, D. Bogarín 3938 (JBL). Map 4.

19. Pleurothallis fantastica Ames, Bot. Mus. Leafl. 4(4): 45. 1936. Acronia fantastica (Ames) Luer, Monogr. Syst. Bot. Missouri Bot. Gard. 103: 134. 2005. TYPE: Costa Rica: San José: vicinity of El General. Epiphyte on trees by a river, 830 m, Jan. 1936. Flowers yellow. A. F. Skutch 2391 (Holotype: AMES; Isotype: AMES). Pleurothallis horichii Luer, Orchidee (Hamburg) 36(1): 23. 1985. TYPE: Costa Rica. Cordillera Brunquena, between Pacuarito - El Alto de San Juan, 1100 m, 26 May 1982, collected by C. Horich, 

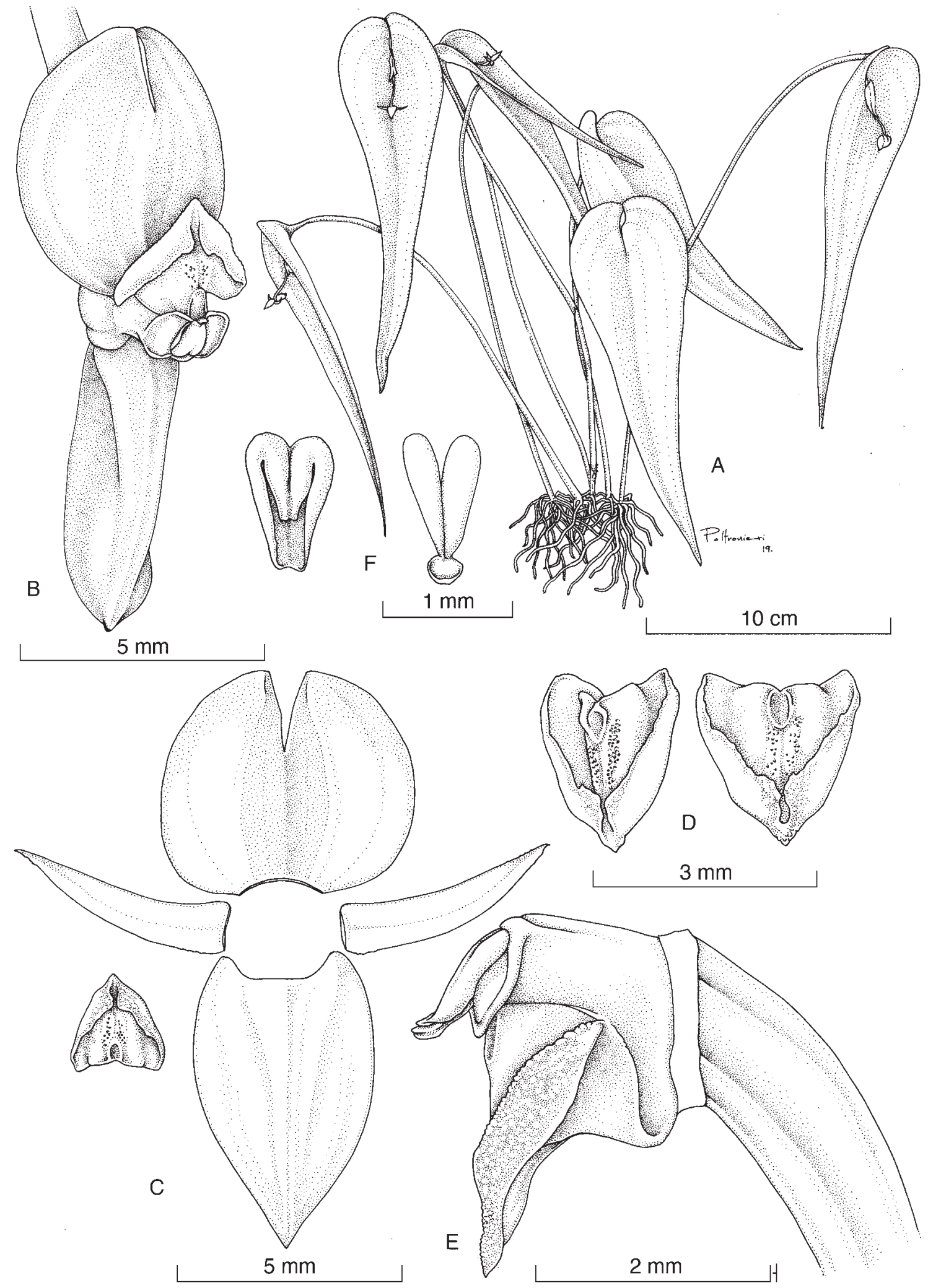

FIgure 38. Pleurothallis compressa Luer. A, habit; B, flower; C, dissected perianth; $\mathbf{D}$, lip in three quarters and adaxial views; $\mathbf{E}$, apex of ovary, column, and lip in lateral view; F, anther cap and pollinarium. Drawn by S. Díaz Poltronieri from Bogarín 7839 (JBL). 
flowered in cultivation in Bern, Switzerland, R. Jenny P-113 (Holotype: MO). Fig. 39 (Voucher, Blanco 5087, JBL).

Epiphytic, caespitose, arching to pendent herb up to $40 \mathrm{~cm}$ tall. Roots slender, flexuous, ca. $1 \mathrm{~mm}$ in diam. Ramicauls slender, 10-23 cm long, 1-2 $\mathrm{mm}$ in diam., terete at the base, becoming slightly ancipitous distally, pale green, with 2 basal, short, tubular, obtuse sheaths, and another tubular, cylindrical, tightly adpressed sheath below the middle, the lower ones 8-14 mm long, the upper to 40 $\mathrm{mm}$ long, the sheaths dry-papyraceous, brown. Leaf borne at the apex of the ramicaul, pendent, rigidly coriaceous, sessile, narrowly ovate, acute, tapering to a subacuminate, mucronate apex, concave at the base, green, matte, 10-14 cm long, 1.7-2.2 cm wide, the basal lobes suberect, decurrent on the ramicaul for about $15 \mathrm{~mm}$. Inflorescence a fascicle of solitary flowers, produced in succession from a prostrate, rectangular, obliquely truncate, glumaceous, green, spathaceous bract emerging above the base of the leaf, 5-7 mm long, becoming brown, dry-papyraceous when mature and eventually fugacious; the peduncle terete, mostly adnate to the leaf, to $2 \mathrm{~cm}$ long. Pedicel terete, green, 5-6 $\mathrm{mm}$ long. Ovary terete, subclavate, ca. $5 \mathrm{~mm}$ long. Flowers spreading to slightly reflexed, concolorous pale yellow to greenish yellow, the midlobe and the disc of the lip reddish brown. Dorsal sepal erect, elliptic, subacute, the margins reflexed, 6-7 $\times 4 \mathrm{~mm}, 5$-veined. Lateral sepals connate into a broadly elliptic, obtuse, minutely emarginate synsepal, the margins reflexed, $5 \times 4 \mathrm{~mm}$, each half 4 -veined. Petals broadly asymmetrically lanceolate, subfalcate, acute, glandulose, the margins cellular 5-6 $\times 3 \mathrm{~mm}, 3$-veined. Lip fleshy, adnate to the base of the column, transversely 3 -lobed, $3 \times 4 \mathrm{~mm}$ when spread, the lateral lobes transversely elliptic-rheniform, obliquely erect, minutely glandulose, the midlobe ellipticsubquadrate, bilobulate-retuse, distinctly glandulose, with a minute abaxial apiculum, ca. $1 \times 1 \mathrm{~mm}$, the disc with a low, bilobed callus. Column terete, stout, distinctly dilated distally, minutely glandulose, ca. $3 \times 2 \mathrm{~mm}$, the anther apical, incumbent, the stigma apical, bilobed. Anther cap cucullate, ovate, subcordate, truncate, 2-celled. Pollinia 2, narrowly ovoid, attached to an elliptic viscidium. Fig. 31I.

Etymology: from medieval Latin fantasticus, "imaginary," but also "wonderful, marvelous," in allusion to the shape of the flowers in this species, which do not resemble any other Pleurothallis in the American tropics.

Distribution: known only from Costa Rica.

Ecology: growing as an epiphyte in secondary vegetation along rivers, in premontane moist forest between 950 and $1400 \mathrm{~m}$ in elevation, on both the Caribbean and Pacific watersheds of the Continental Divide. Flowering has been recorded from January to June, and in September.

Distinguishing features: it is easy to distinguish Pleurothallis fantastica from any other species in the genus by the long, narrow, pendent leaves borne on a distally ancipitous ramicaul, which are cuneate (not cordate) at the base, and the flower showing a distinctly 3-lobed lip, the lateral lobes broad, elliptic, spread out, and the midlobe small, excised.

Pleurothallisfantastica could seem an obvious misfit here. Morphologically, it has no close relatives either in the flora of Costa Rica or in any other floras of the American tropics. Vegetatively, however, it more closely resembles species of the P. phyllocardia group, and particularly P. compressa, than any other Pleurothallis taxa known in Central America. In the other species of the group, mature, flowering stems end into a leaf that is basally deeply cordate, while juvenile leaves are mostly cuneate or rounded at the base. We interpret here the cuneate leaves on fertile stems of $P$. fantastica as a retention of the paedomorphic form, which is otherwise characteristic of the juvenile stage within the group.

Both the photograph and the drawing of Pleurothallis horichii published by Luer (1985) leave no doubt about the fact that this species, also native from the mountains surrounding the El General Valley in southern Costa Rica, is conspecific with P. fantastica.

Costa Rican material examined: Cartago: Paraíso, Orosi, P.N. Tapantí-Macizo de La Muerte, entre Quebrada Salto y Río Humo, 9.7194444, -83.7833333, 1200-1350 m, 27 Jun 2004, J. F. Morales Quirós 10842 \& L. Muñoz (CR). Puntarenas: Coto Brus, San Vito, Estación Biológica Las Cruces, Reserva Biológica, Río Java, Sendero Ridge, $1340 \mathrm{~m}, 8.7856^{\circ} \mathrm{N}, 82.9772^{\circ} \mathrm{W}$, epífita en árbol caído, 6 Oct 2018, M. Blanco 5087, N. Jiménez, O. Alvarado, M. Cedeño, K. Gil \& M. J. Mata (JBL). Coto Brus, Sabalito, ca. $8^{\circ} 49^{\prime} \mathrm{N}, 82^{\circ} 55^{\prime} \mathrm{W}, 1020 \mathrm{~m}$, collected by M. Flores, flowered in cultivation at Gaia Botanical Garden, 2 Sept 2001, F. Pupulin 3329 (JBL). San José: Pérez Zeledón, San Ramón, unpaved road to Las Pegas, Páramo, Los Angeles, shore of Río División, 9²9'58"N, 8345'49"W, 1390 m, premontane moist forest, epiphytic in secondary vegetation along the river, 20 april 2003, F. Pupulin 4667, J. Cambronero, $H$. Leon-Paéz, M. Powell, E. Salas \& V. Savolainen (JBL). Dota, Santa María, San Joaquín. Río San Joaquín. Sobre un árbol caído al lado del río. $955 \mathrm{~m}, 09^{\circ} 35^{\prime} 10^{\prime \prime} \mathrm{N}, 84^{\circ} 00^{\prime} 36^{\prime \prime W}$ 20 de febrero 2012, A. P. Karremans 5120 (JBL). Dota, Santa María, entre San Joaquín y La Guaria, Desamparados, R.F. Los Santos, San Rafael Arriba, casa de Ana Morales, 9.6000000, -83.9777778, 1400-1700 m, 11 Jul 2004, J. F. Morales Quirós 10892 \& L. Muñoz (CR). Dota, Santa María, R.F. Los Santos, San Joaquín, Quebrada Pirranga. 9.590277, -83.9819444, 1300-1500 m, 22 Nov 2003, J. F. Morales Quirós 10135 (CR). Map 4.

20. Pleurothallis longipetala Bogarín \& Belfort, sp. nov. TYPE: Costa Rica. Cartago: Paraíso, Orosi, Tapantí, camino entre Tapantí y Tausito, cerca del Restaurante

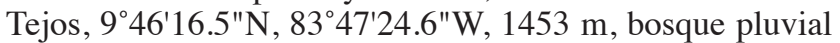
premontano, recolectada por Daniel Jiménez, 8 noviembre 2005, D. Bogarín 9428 (Holotype: JBL-Spirit). Fig. 40 (Voucher, Bogarín 9428, JBL).

Species affinis Pleurothallis luna-crescente Pupulin, J.Aguilar et Mel.Fernández, $P$. radula Luer et $P$. rectipetala Ames et $\mathrm{C}$. Schweinf., sepalibus non reflexis quando perfectis, labello erecto, petalis distincte longioribus, glenione transverse rectangularis ab omnibus differt; floribus purpureis vel sordide flavis purpureo striatis a $P$. radula facile recedit; floribus planis a illis forma lunaecrescentis $P$. luna-cescente distinguitur; petalis quam sepalis longis a $P$. rectipetala expedite noscitur. 


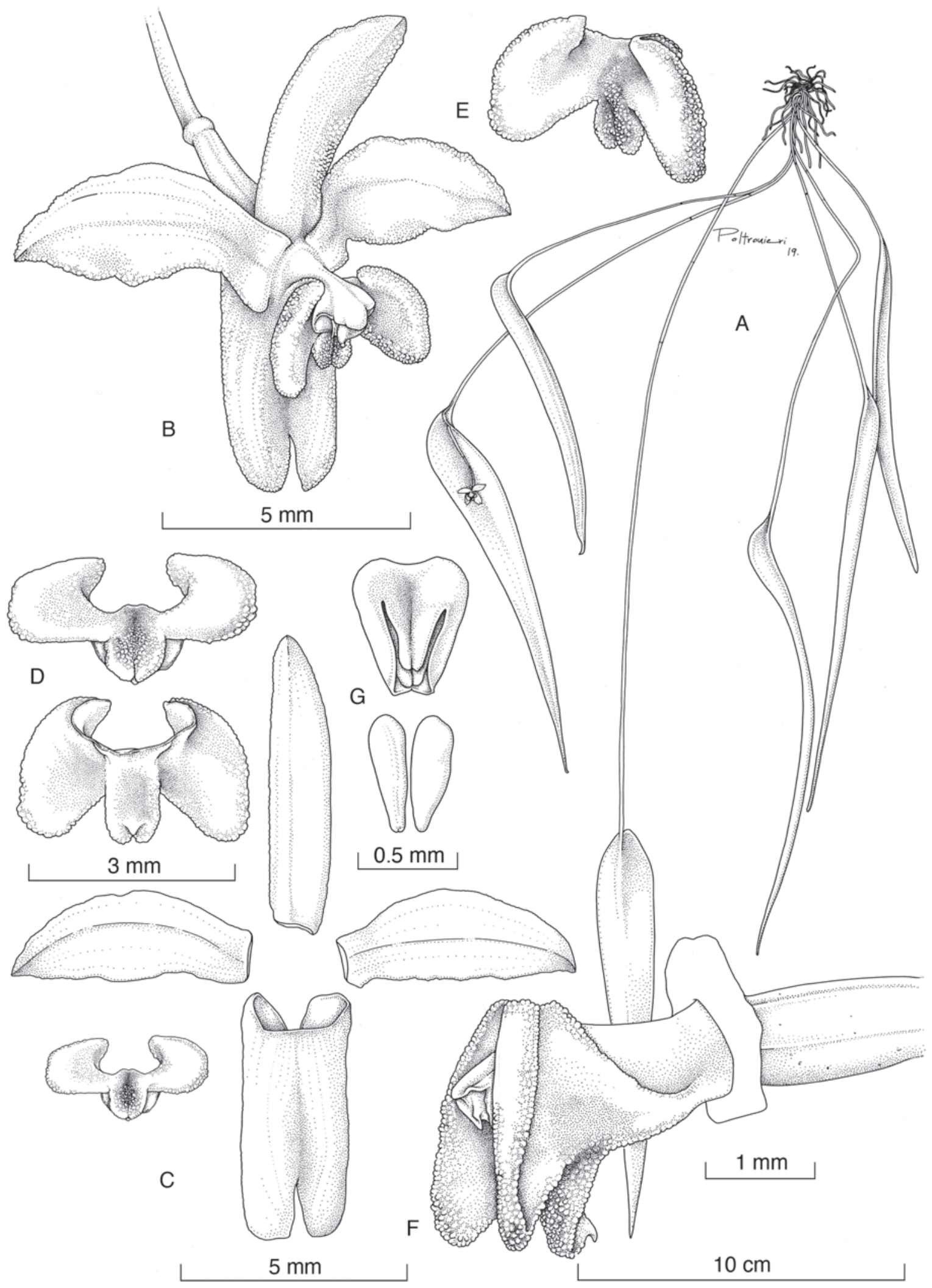

FIgure 39. Pleurothallis fantastica Ames. A, habit; B, flower; C, dissected perianth; D, lip in adaxial and abaxial views; E, lip, three quarters view; F, apex of ovary, column, and lip, lateral view; G, anther cap and pollinarium. Drawn by S. Díaz Poltronieri from Blanco 5087 (JBL). 


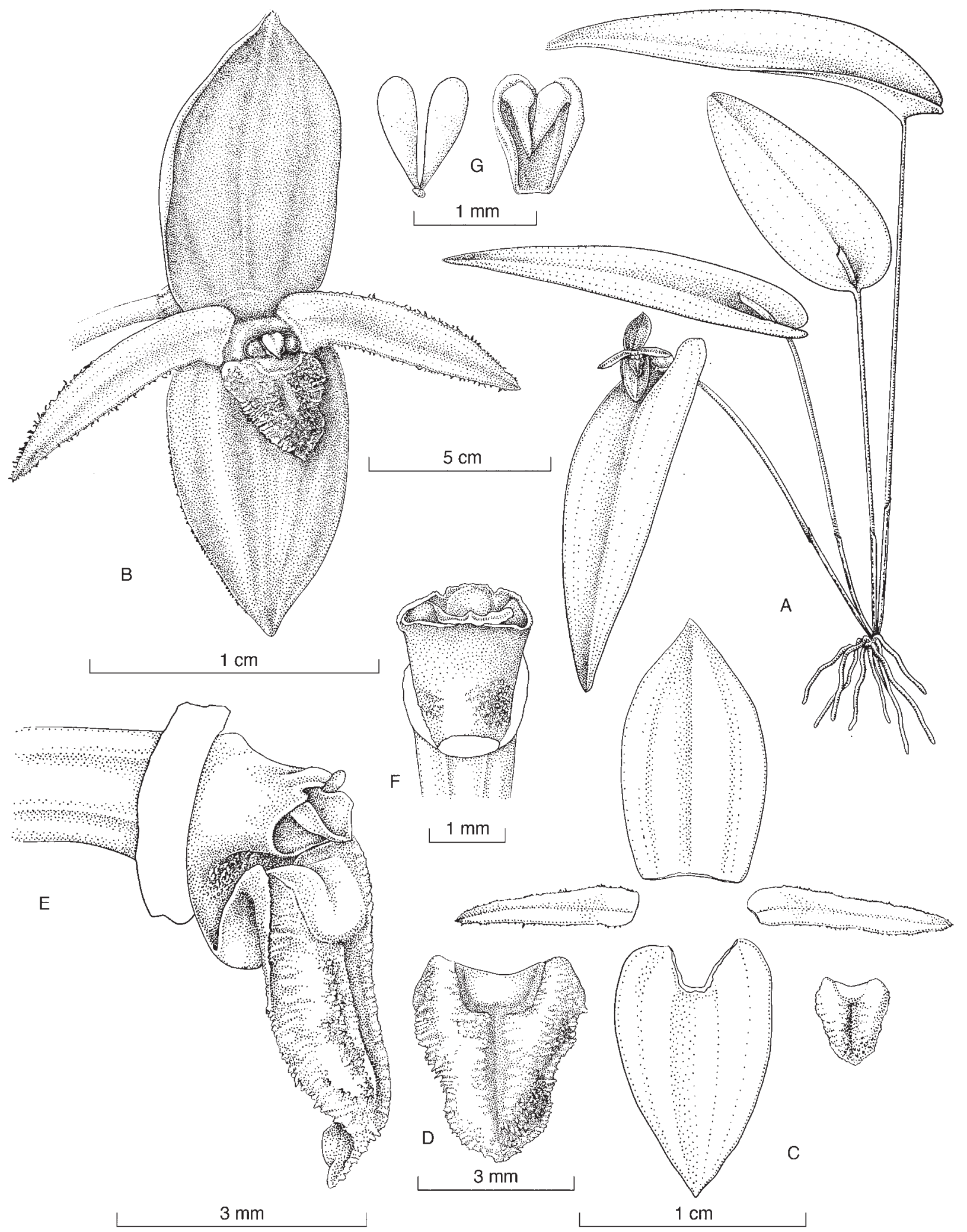

FIgURE 40. Pleurothallis longipetala Bogarín \& Belfort. A, habit; B, flower; C, dissected perianth; D, lip, adaxial view; E, apex of ovary, column, and lip in three-quarter view; F, column, ventral view; G, pollinarium and anther cap. Drawn by S. Díaz Poltronieri from Bogarín 9428 (JBL). 
Epiphytic, caespitose, erect to suberect herb up to 20 $\mathrm{cm}$ tall. Roots slender, flexuous, less than $1 \mathrm{~mm}$ in diam. Ramicaul terete, slender, erect to suberect, up to $15 \mathrm{~cm}$ long, enclosed by 1 closely adpressed, tubular, long, acuminate sheath, which covers the first third of the ramicaul, pale green, aging dry-papyraceous, brown. Leaf horizontal to subhorizontal, soft coriaceous, narrowly ovate-lanceolate, 9-11 × 2.8-3.1 cm, the base sessile, deeply cordate, the basal margins not overlapping. Inflorescence singleflowered, produced in succession and emerging from a papyraceous, suberect spathe, $15-16 \mathrm{~mm}$ long, eventually disintegrating with age. Peduncle terete, ca. $15 \mathrm{~mm}$ long. Pedicel ca. $10 \mathrm{~mm}$ long. Ovary cylindrical, ca. $2 \mathrm{~mm}$ long. Flowers erect, resupinate, with purple sepals, veins dark purple, the petals and lip dark purple, the column whitish green suffused with dark purple in the apical portion. Dorsal sepal erect, slightly concave, narrowly ovate-acuminate, acute, $11 \times 6 \mathrm{~mm}$, 3-veined. Lateral sepals connate into an ovate-acuminate, basally slightly concave synsepal, $11 \times 7$ $\mathrm{mm}$, the margins slightly reflexed, 5-veined. Petals linearacuminate, acute, serrulate, held horizontally, 7.9-8.6 × 1.6$1.7 \mathrm{~mm}, 1$-veined. Lip unguiculate, hinged to the column foot, geniculate, basally bilobulate, thick, fleshy, obtuse, $3.7-3.9 \times 3.3 \mathrm{~mm}$, densely verrucose on the adaxial surface, the lamina provided with a basal transversely rectangular glenion, ca. $1 \mathrm{~mm}$ long, recessed between the basal lobes of the lip. Column short, stout, transversely subrectangular, 2.3-2.5 $\mathrm{mm}$ long, the foot ca. $1.5 \mathrm{~mm}$, densely papillose; stigma and anther apical. Pollinia 2, narrowly obpyriform, $0.9 \mathrm{~mm}$ long, provided with inconspicuous caudicles, and a hard, bubble-like viscidium. Fig. 41A.

Etymology: from the Latin longipetalus, "with long petals," in allusion to the length of the petals, subequal to that of the sepals, which is uncommon in this group of Pleurothallis species.

Distribution: known only from Costa Rica, in the Pacific and Caribbean watershed foothills of the northcentral Cordillera de Talamanca.

Ecology: epiphytic in premontane rain forest between 1400-2800 $\mathrm{m}$ in elevation. The plant has been recorded in flower from September to March.

Distinguishing features: the flat flower, with the sepals not swept back at maturity, the long petals, and the erect lip provided with a transversely rectangular glenion are diagnostic of $P$. longipetala.

Pleurothallis longipetala is similar to P. luna-crescens, $P$. radula, and $P$. rectipetala, but it is distinguished from those species by the margins of the sepals not swept back at maturity, the erect lip (instead of reclinate over the synsepal), the distinctly longer petals, and the transversely rectangular glenion of the lip, which is unique to it. The purple or dull-purplish-yellow flowers boldly striped with purple easily separates it from $P$. radula, whose flowers are concolorous yellow, while the almost flat flower (except for the erect lip) distinguishes it at first glance from the crescent moon-shaped flowers of P. luna-cescens. The long petals, almost equal in length to the sepals, cannot be mistaken for those of $P$. rectipetala, which are distinctly shorter than the sepals.
Costa Rican material examined: San José: Pérez Zeledón, Rivas, Herradura, Fila Palmito Morado, $9^{\circ} 30^{\prime} 21.74 " \mathrm{~N}, 83^{\circ} 34^{\prime} 05.52^{\prime \prime} \mathrm{W}, 2788 \mathrm{~m}$, colectada por Denis Elizondo, floreció en cultivo en el Jardín Botánico Lankester, 3 Setiembre 2011, D. Bogarín 9253 (JBL). Map 4.

21. Pleurothallis luna-crescens Pupulin, J. Aguilar \& Mel. Fernández, Lankesteriana 17(2): 158-163. 2017. TYPE: Costa Rica. Cartago: Turrialba, Tayutic, Grano de Oro. On the road to the premontane forest, next to the road between Grano de Oro and Llanos del Quetzal, $2 \mathrm{~km}$ after crossing a river with a broken bridge. $9^{\circ} 48^{\prime} 23^{\prime \prime} \mathrm{N}, 83^{\circ} 26^{\prime} 53^{\prime \prime} \mathrm{W}$, 1000-1200 m, 30 July 2005, A. P. Karremans 881 \& P. Ferreira (Holotype: CR; Isotypes: JBL). Fig. 42 (Voucher, Karremans 881, JBL).

Epiphytic, caespitose, erect herb up to $30 \mathrm{~cm}$ tall. Roots slender, flexuous, ca. $1 \mathrm{~mm}$ in diam. Ramicauls terete, slender, 7.5-28.0 cm long, ca. $3 \mathrm{~mm}$ in diam., pale green, with a basal, tubular, truncate sheath, $2.5-4.2 \mathrm{~cm}$ long, and a sub-basal, tubular, obtuse, tight sheath $2.3-5.2 \mathrm{~cm}$ long, dry-papyraceous, brown when mature. Leaf borne erect at the apex of the ramicaul, becoming subpendent with age, thinly coriaceous, flexible, sessile, lanceolate, acute, shortly subacuminate, $6.5-12.5 \times 3.0-5.5 \mathrm{~cm}$, deeply cordate at the base, green, sometimes irregularly mottled with purple along the margins, matte. Inflorescence a solitary flower from an erect, rectangular-subclavate, truncate, spathaceous bract 2.2-2.6 cm long, glumaceous, green, becoming brown, dry-papyraceous with age. Peduncle terete, ca. 10 $\mathrm{mm}$ long, completely hidden by the spathe. Pedicel terete, green, to $2.2 \mathrm{~cm}$ long. Ovary terete, subclavate, 6-7 $\mathrm{mm}$ long. Flowers spreading, the sepals and petals purple red, the lip dark purple. Dorsal sepal incurved, lanceolate, acute, 15.0-16.5 × 6.5-7.0 mm, the margins reflexed, 3-veined. Lateral sepals connate into an ovate, obtuse synsepal, the margins slightly reflexed, incurved, 14.8-15.3 × 8.0-8.5 $\mathrm{mm}, 5$-veined. Petals narrowly ovate, acute, dentate, 8.7$9.0 \times 2.8-3.0 \mathrm{~mm}$, single-veined. Lip unguiculate, hinged to the column foot, ovate, basally truncate with obtuse angles, obtuse, minutely apiculate, $4.0-4.5 \times 2.2-2.8 \mathrm{~mm}$, minutely papillate; glenion raised on a thick callus on the disc, ca. 0.6 $\mathrm{mm}$ long. Column short, stout, transversely subrectangular, dorsiventrally complanate, ca. $2.0 \times 1.3 \mathrm{~mm}$, the anther apical, incumbent, the stigma apical, bilobed. Anther cap cucullate, ovate, subcordate, truncate, 2-celled, ca. $0.9 \times$ $0.7 \mathrm{~mm}$. Pollinia 2, narrowly ovate-pyriform, $0.8 \mathrm{~mm}$ long, attached to an elliptic viscidium. Fig. 41B-C.

Etymology: from the Latin luna crescens, "crescent moon," in reference to the characteristic shape of the flower seen in profile, due to the strongly reflexed-incurved sepals.

Distribution: known only from the Caribbean slopes of the northern Cordillera de Talamanca, in central Costa Rica.

Ecology: epiphytic on branches in the partial shade of the lower canopy, in lower montane and premontane rain to wet forest at $1000-1650 \mathrm{~m}$ in elevation. The species mostly flowers in June-August, with early flowering recorded in February-March.

Distinguishing features: the crescent-shaped, purple flowers with a finely rugulose lip, and the long, strongly dentate petals are distinctive of $P$. luna-crescens. 


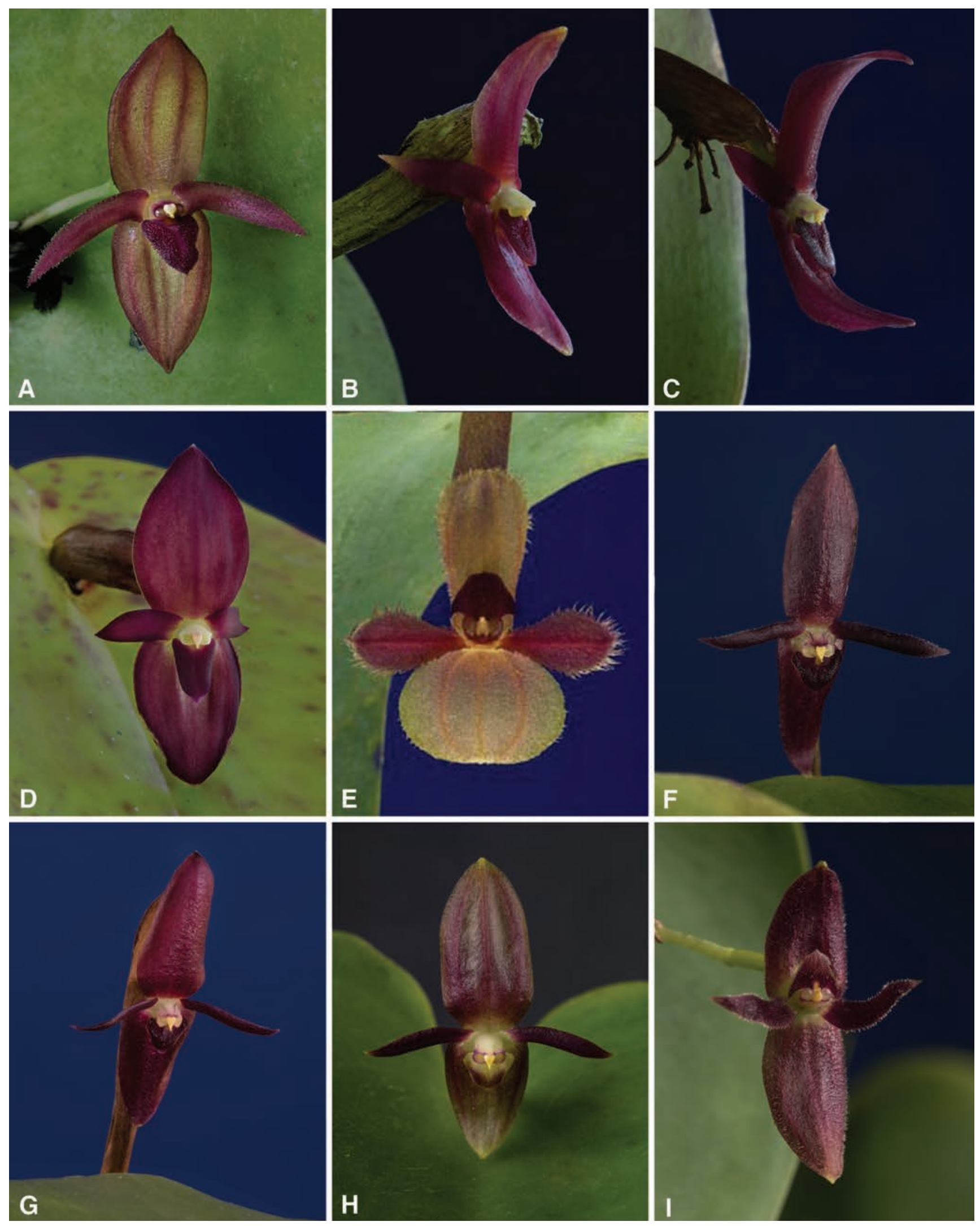

FIgURE 41. Flowers of Pleurothallis species from Costa Rica in the P. phyllocardia group. A, P. longipetala (Bogarín 9428); B-C, P. luna-crescens (Zúñiga 178; Karremans 881); D, P. mesopotamica (Bogarín 8811); E, P. peculiaris (Bogarín 5972); F-H, P. phyllocardia (Bogarín 10664; Bogarín 7709; Chinchilla 3407); I, P. pudica (Karremans 6249). Not at the same scale. All the vouchers at JBL. Photographs by F. Pupulin except D-E (D. Bogarín). 

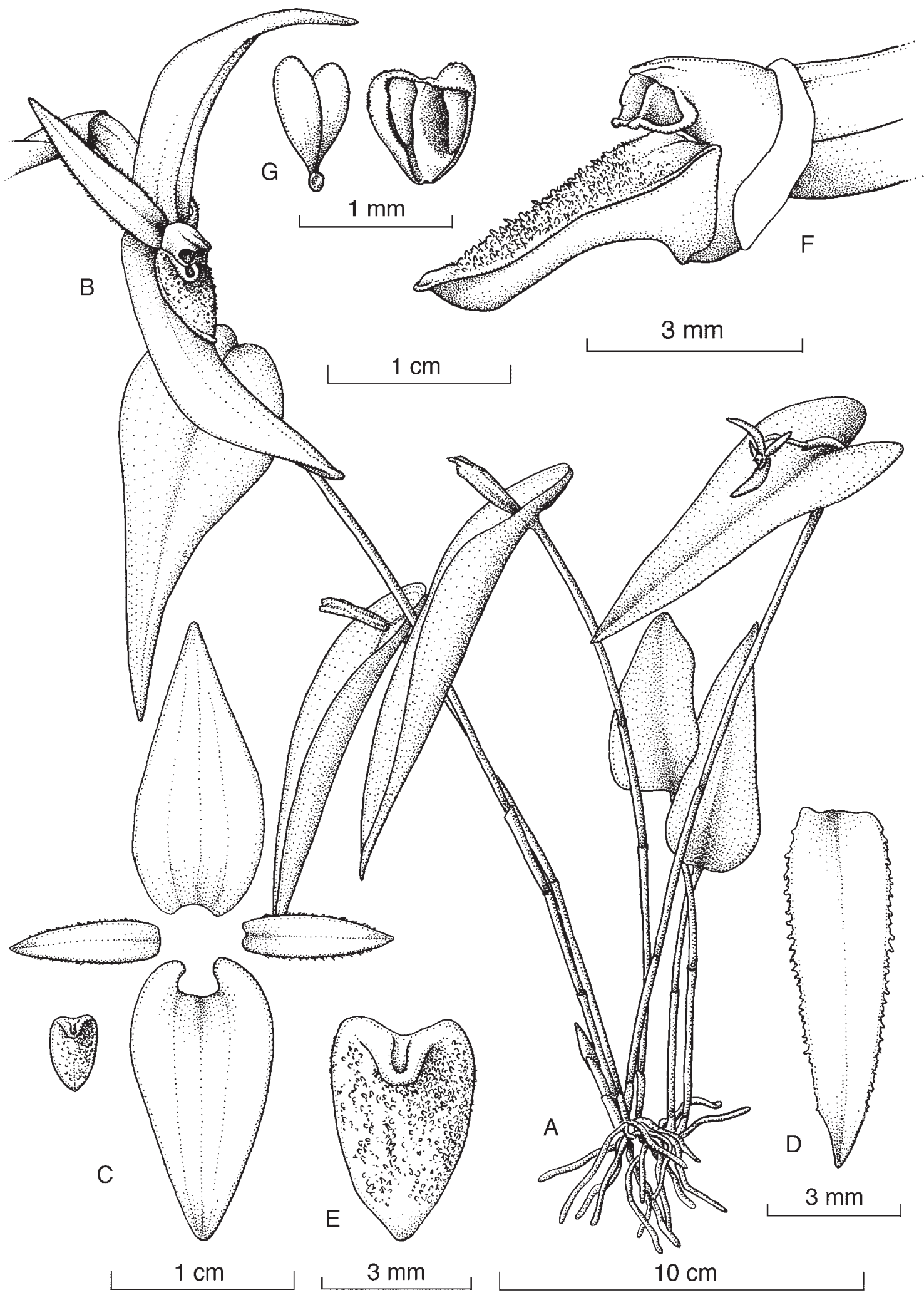

Figure 42. Pleurothallis luna-crescens Pupulin, J. Aguilar \& Mel. Fernández. A, habit; B, flower; C, dissected perianth; D, left petal; $\mathbf{E}$, lip, adaxial view; F, apex of ovary, column, and lip in lateral view; G, pollinarium and anther cap. Drawn by S. Díaz Poltronieri from Karremans 881 (JBL). 
Costa Rican material examined: Cartago: Cartago, San Francisco, Navarro, Muñeco, Fincas Loma Verde y Jilguero, road to Alto Belén, between Río Sombrero and Quebrada Patarrá, 946'50.3"N, 8354'21.1"O, 1430-1620 $\mathrm{m}$, premontane rain forest, secondary woods and margins of the road, 23 May 2007, J. D. Züñiga 178, D. Bogarín, M. Bonilla, R. Gómez, R. L. Dressler \& R. Trejos (JBL). Orosi, Tapantí, Parque Nacional Tapantí, sendero Árboles Caídos, $1280 \mathrm{~m}$, epiphytc on low trunks in primary wet submontane forest, 6 Feb. 2000, F. Pupulin 1981 (USJ). Turrialba, La Suiza, Llanos del Quetzal, ca. 1 km sobre el camino detrás de la Escuela de Kabébata (Alto Quetzal), epífitas en vegetación secundaria, bosque muy húmedo premontano, $9^{\circ} 46^{\prime} 39.53^{\prime \prime} \mathrm{N}, 83^{\circ} 24^{\prime} 45.80^{\prime \prime} \mathrm{W}, 1449$ m. 22 setiembre 2016, M. Díaz 279, I. Chinchilla, A. Karremans y G. RojasAlvarado (JBL). Turrialba, La Suiza, Llanos del Quetzal, ca. $1 \mathrm{~km}$ on the road behind the School of Kabébata (Alto Quetzal), epiphytic in primary and secondary vegetation, premontane wet forest, $9^{\circ} 46^{\prime} 43.6^{\prime \prime} \mathrm{N}, 83^{\circ} 24^{\prime} 41.6^{\prime \prime} \mathrm{W}, 1450$ m, 17 Jun. 2011, A. P. Karremans 4262, M. Fernández \& D. Bogarín (JBL). Turrialba, La Suiza, Llanos del Quetzal, road to Chirripó Abajo, 946'55.4"N, 83²4'21.0"W, 1411 $\mathrm{m}$, epiphytic in secondary vegetation around the road, premontane wet forest, 17 Jun. 2011, M. Fernández 461, A. Karremans \& D. Bogarín (JBL). Turrialba, Tayutic, Platanillo. Hillside of the Platanillo River, 9 $49^{\prime} 11^{\prime \prime N}$, 833'37"W, 700-900 m, 30 April 2005, A. Karremans 801 (JBL). [Turrialba,] Alto Pacuare, epiphyte, purple flowers, alt. 100 m, 21 July 1978, R. A. Ocampo S. 2363 (CR).

\section{Pleurothallis mesopotamica Bogarín \& Belfort, sp.} nov.

TYPE: Costa Rica. Cartago: Cartago, San Francisco, Muñeco, Navarro, $3 \mathrm{~km}$ al sur de la iglesia de Navarro, entre Río Sombrero y Quebrada Patarrá, 945'54.84"N, $83^{\circ} 54^{\prime} 22.51^{\prime \prime} \mathrm{W}, 1579 \mathrm{~m}$, bosque pluvial premontano, "ad sylva secundaria et primaria prope oppidum Navarro ad margines viam ubi Standley probabiliter Trichosalpinx navarrensis, Eurystyles standleyi et Coccineorchis navarrensis invenit," 12 Mayo 2011, D. Bogarín 8811, M. Fernández, R. Gómez, A. Karremans \& C. Smith (Holotype: JBL). Fig. 43 (Voucher, Bogarín 8811, JBL). Map 4.

Pleurothallide rectipetala Ames et C. Schweinf. plerumque similis, bractea spathacea suberecta, flore atropurpureo, petalis subfalcatis marginibus integris labelloque verrucoso recedit; a Pleurothallide radula Luer etiam confert, flore arropurpureo labello paulo verrucoso dignoscenda.

Epiphytic, caespitose, erect herb, up to $25 \mathrm{~cm}$ tall. Roots slender, flexuous, ca. $1 \mathrm{~mm}$ in diam. Ramicauls terete, slender, 8-25 cm long, 2.5-3.0 mm in diam., pale green, with 2 basal, tubular, obtuse, dry-papyraceous sheaths,17.5-42.5 $\mathrm{mm}$ long, the second longer than the basal one, brown. Leaf borne at the apex of the ramicaul, horizontal to subreclinate toward the stem, thinly coriaceous, flexible, sessile, narrowly ovate, acuminate, $12-16 \times 3.5-5.0 \mathrm{~cm}$, cordate at the base, the basal lobes overlapping, pale green with scattered purple spots, matte. Inflorescence a solitary flower, born from a suberect, oblanceolate, rounded to subtruncate, spathaceous bract to $11 \mathrm{~mm}$ long, becoming brown, drypapyraceous with age. Pedicel terete, green, to ca. $15 \mathrm{~cm}$ long, completely hidden within the spathe. Ovary terete, curved, less than $5 \mathrm{~mm}$ long and $2 \mathrm{~mm}$ wide. Flowers erect, spreading-reflexed; the sepals purple becoming darker to the distal portion, with whitish margins and tip; the petals dark purple; the lip dark purple with light-purple glenion; the column white, with the margins of the clinandrium light purple, the anther cap light yellow. Dorsal sepal erect, broadly ovate, obtuse to subacute, $1.2-1.3 \times 0.9 \mathrm{~cm}$, the margins reflexed, 7-veined. Lateral sepals connate into a broadly ovate, obtuse to subacute, synsepal, the margins reflexed, $1.1 \times 0.9 \mathrm{~cm}$, each half 4 -veined. Petals subfalcate, acute, with entire margins, reflexed at complete anthesis, 6-7 $\times 2 \mathrm{~mm}, 1$-veined. Lip unguiculate, hinged to the column foot, thick and fleshy, ovate-peltate, basally truncate with obtuse angles, obtuse-rounded,the sides smooth, $4 \times 3$ $\mathrm{mm}$, slightly verrucose throughout; glenion raised on a thick callus on the disc, less than $1 \mathrm{~mm}$ long. Column short, stout, transversely subrectangular, dorsiventrally complanate, $2.4 \times 1.3 \mathrm{~mm}$, with a short foot, ca. $1 \mathrm{~mm}$ long; the anther apical, incumbent, the stigma apical, bilobed. Anther cap cucullate, ovate, subcordate, subtruncate, two-celled, $0.9 \times$ $0.7 \mathrm{~mm}$. Pollinia 2, narrowly ovate, attached to an elliptic viscidium. Fig. 41D.

Etymology: from the Greek $\mu$ ćoos, "mésos," meaning

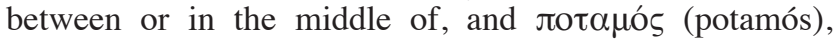
"river," alluding to the region where the type specimen was collected, between the Sombrero and Patarrá rivers in central Costa Rica.

Distribution: known only from Costa Rica.

Ecology: the only specimen known was found growing as an epiphyte in premontane moist forest at an elevation of $1579 \mathrm{~m}$. The flowering has been recorded in January and February.

Distinguishing features: Pleurothallis mesopotamica is very similar to $P$. rectipetala but can be distinguished by the suberect spathe (vs. erect), the dark purple flowers (vs. dull purple flowers with yellow near the margins), the subfalcate petals with entire margins (vs. linear-lanceolate, minutely denticulate petals), and the verrucose lip (vs. irregularly papillose lip). It could be also compared with $P$. radula, from which it differs in the dark purple flowers (vs. yellow, rarely suffused with pink) and the slightly verrucose lip (vs. densely packed with shortly tuberculate-dentate, irregular projections).

23. Pleurothallis peculiaris Luer, Selbyana 3(1-2): 158159. 1976. TYPE: Panama: Veraguas: epiphytic in the cloud forest near the continental divide above Santa Fé, alt. ca. 700 m, Sept 1976, C. Luer \& R. L. Dressler 1142 (Holotype: SEL). Fig. 44 (Vouchers, Solís 25 and Bogarín 5972, CR, JBL).

Epiphytic, caespitose, arching to pendent herb up to $40 \mathrm{~cm}$ tall. Roots slender, flexuous, ca. $1 \mathrm{~mm}$ in diam. Ramicauls terete, slender, 15-40 cm long, ca. $2 \mathrm{~mm}$ in diam., pale green, with 2 basal, short, tubular, obtuse sheaths, and 


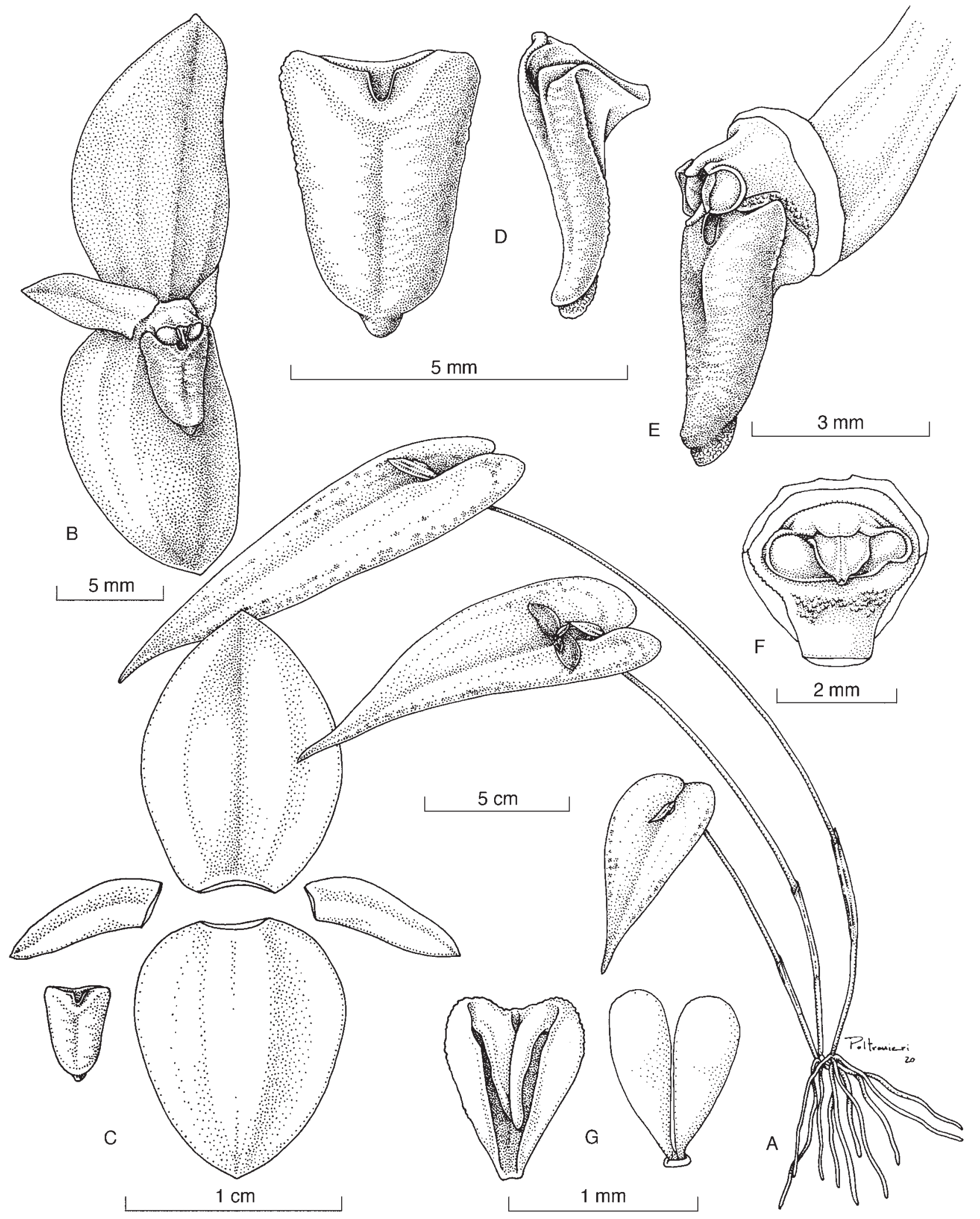

Figure 43. Pleurothallis mesopotamica Bogarín \& Belfort. A, habit; B, flower; C, dissected perianth; D, lip in adaxial and lateral views; $\mathbf{E}$, apex of ovary, column, and lip, lateral view; F, column, frontal view; G, anther cap and pollinarium. Drawn by S. Díaz Poltronieri from Bogarín 8811 (JBL). 


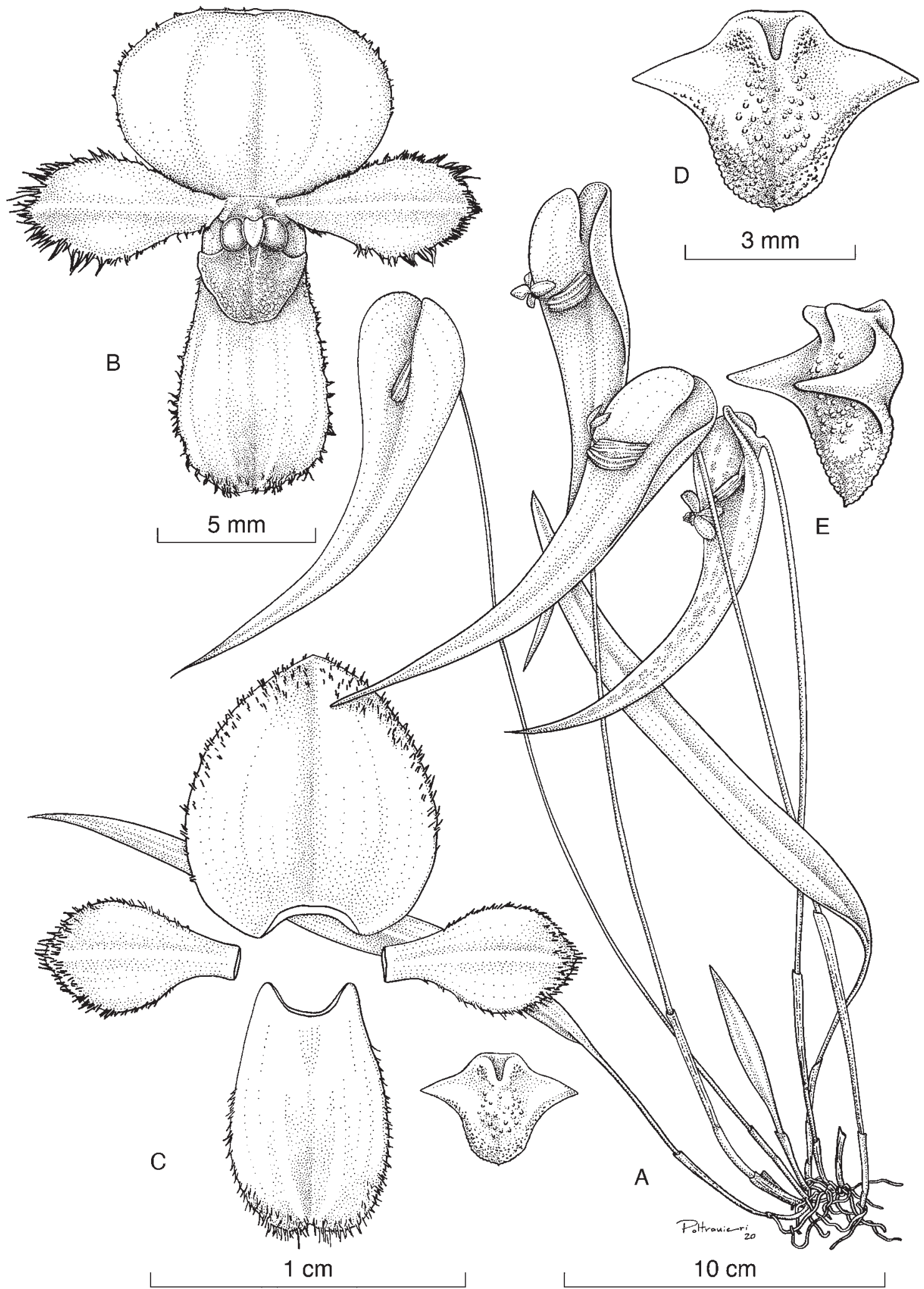

FIGURE 44. Pleurothallis peculiaris Luer. A, habit; B, flower; C, dissected perianth; D, lip, adaxial view; E, lip, three quarters view. Drawn by S. Díaz Poltronieri from Solís 25 and Bogarín 5972 (CR, JBL). 
another tubular, tightly adpressed sheath below the middle, the lower ones 7-16 mm long, the upper one to $55 \mathrm{~mm}$ long, the sheaths dry-papyraceous, brown. Leaf borne at the apex of the ramicaul, sessile, deflexed, rigidly coriaceous, concave, incurved, narrowly ovate, attenuate, tapering to an acuminate, tri-denticulate apex, the base deeply cordate with the lobes suberect, overlapping, green to sparsely blotched with purple, matte, 12-15 × 3-3 cm. Inflorescence a fascicle with a solitary flower, produced from an erect, subrrectangular, obliquely truncate, spathaceous bract emerging at the base of the leaf, ca. $10 \mathrm{~mm}$ long, brown, dry-papyraceous; the peduncle terete, to $15 \mathrm{~mm}$ long. Pedicel terete, green, $12 \mathrm{~mm}$ long, completely hidden by the spathe. Ovary terete, to $7 \mathrm{~mm}$ long. Flowers nonresupinate, spreading, the margins of the synsepal reflexed, the sepals translucent yellow, striped and boldly suffused with red along the veins, the petals purple, with white hairs along the margins, the lip dark purple, the column rose-purple. Dorsal sepal erect, broadly ovate to suborbicular, obtuse to subrounded, the margins and the apical part pilose-hirsute, $9 \times 8 \mathrm{~mm}, 3$-veined. Lateral sepals connate into an oblong to narrowly obovate, rounded, minutely emarginate-retuse synsepal, the margins pilose, reflexed at the middle, $8 \times 5$ $\mathrm{mm}$, each half 2 -veined. Petals obovate-spatulate, obtuse, glandulose-papillose, the margins long-hirsute, with a thickened, rounded, low keel along the vein, $6.0 \times 3.5$ $\mathrm{mm}, 1$-veined. Lip fleshy, adnate to the base of the column, subrhombic to trapezoidal-sagittate, 3-lobed, obtuse to rounded, the margins minutely erose, $3.5 \times 5.0 \mathrm{~mm}$ when spread, the lateral lobes digitate, acuminate, inserted below or at the middle, spreading to retrorse, the midlobe triangular, verrucose, with a minute apiculum, the disc with two mamillate, erect callosities flanking the glenion. Column rectangular in section, stout, dilated distally, dorsoventrally flattened, ca. $2.5 \times 4 \mathrm{~mm}$, the anther apical, incumbent, the stigma apical, bilobed. Anther cap cucullate, narrowly ovate, 2-celled. Pollinia 2, narrowly ovoid, attached to an elliptic viscidium. Fig. 41E.

Etymology: from the Latin peculiaris, "special, unusual, out of the ordinary," in reference to the several features that this species does not share with other close species of Pleurothallis.

Distribution: Costa Rica and Panama.

Ecology: epiphytic in primary forest in the very wet region of the lower Cordillera de Talamanca, at 700-900 (1300) $\mathrm{m}$ in elevation, on the low and medium Caribbean watershed of the Cordillera de Talamanca. Flowering was recorded from July to December.

Distinguishing features: the long, narrow, acuminate leaves, the erect spathe and the nonresupinate flower with the margins of the sepals pilose, the rounded dorsal sepal much broader than the synsepal, and the spathulate petals with very long, white hairs along the margins make this species unmistakable.

Florally, Pleurothallis peculiaris is highly anomalous in the Pleurothallid flora of Costa Rica. The long-pilose margins of the sepals and petals on a nonresupinate flower, the suborbicular dorsal sepals that largely exceed in width the synsepal, the spathulate petals, and the rhombic lip have apparently no close relatives in the flora of the country. Vegetatively, however, $P$. peculiaris is close to other species of the Pleurothallis phyllocardia group, with lanceolate leaves reclinate toward the stems, deeply cordate at the base, without prominent midvein and matte on the upper surface, provided with an erect spathaceous bract to protect the developing bud. Evidently, the treatment of a flora delimited by political boundaries is not the best strategy to understand the continuum of variation in morphological features that link the taxa to each other in a coherent picture that reflects evolutionary trends in a given group of plants. Comparing it with the much broader range of morphological variations that the $P$. phyllocardia group presents in the Andes, where it is most diverse, we have no doubts that $P$. peculiaris is a South American component of the group in our flora. Such a relationship is nevertheless difficult to envision when this peculiar species is compared, strictly, only with members of the group in the flora of Costa Rica.

Costa Rican material examined: Limón: Talamanca, Fila de exploración minera entre Río Sukut y Río Carbri. Muragubishi. 9²2'50"N, 8256'50"W, 700 m, 14 Jul 1989 , F. Solís 25, G. Herrera \& A. Chacón (CR). Talamanca, R. I. [Indigenous Reserve] Talamanca. Cordillera de Talamanca. Alto Urén. Casa de don Gabriel el Sukia. 9²2'40"N, 8259'00"W, 700-900 m, 21 Sep 1994, G. Gallardo 275 \& E. Lépiz (CR). Map 4.

24. Pleurothallis phyllocardia Rchb.f., Beitr. Orchid.-K. C. Amer. 97. 1866. Humboltia phyllocardia (Rchb.f.) Kuntze, Revis. Gen. Pl. 2: 668. 1891. Zosterophyllanthos phyllocardius (Rchb.f.) Szlach. \& Marg., Polish Bot. J. 46(2): 120. 2001. Acronia phyllocardia (Rchb.f.) Luer, Monogr. Syst. Bot. Missouri Bot. Gard. 103: 173. 2005. TYPE: Costa Rica. Desengaño, 31 May 1858, H. Wendland s.n. (Holotype: W; drawing of type: AMES). Fig. 45 (Voucher, JBL-01967, JBL).

Epiphytic, caespitose, erect to suberect herb to $30 \mathrm{~cm}$ tall. Roots slender, flexuous, ca. $1 \mathrm{~mm}$ in diam. Ramicauls terete, slender, 16-30 cm long, 1-2 mm in diam., yellowish green, provided with a tubular, short, truncate sheath to 2.5 $\mathrm{cm}$ long at the base, and a longer, tubular, tightly adpressed, obtuse sheath below the middle, to $3.7-4.5 \mathrm{~cm}$ long, the bracts glumaceous, pale green when young, becoming brown, dry-papyraceous with age. Leaf borne horizontally at the apex of the ramicaul, becoming subpendent with age, coriaceous, sessile, ovate, acute, 9.0-13.5 × 3.5-7.0 cm, deeply cordate at the base, grass green, matte, becoming dull green with age. Inflorescence a solitary flower, from an erect spathaceous bract 1.4-1.6 cm long, green, dry-papyraceous when mature, eventually dissolving with age. Pedicel terete, pale green, bending down throughout anthesis, 13-16 mm long. Ovary subclavate, terete, 4-6 mm long. Flowers solid dark purple. Dorsal sepal narrowly ovate, acute, minutely papillose on the adaxial surface, reflexed, 13-14 × 5-7 mm, 5-veined. Lateral sepals connate into a narrowly ovate, acute synsepal, minutely papillose on the adaxial surface, reflexed, 10-13 × 4-5 mm, 5-veined. Petals linear-oblong, 


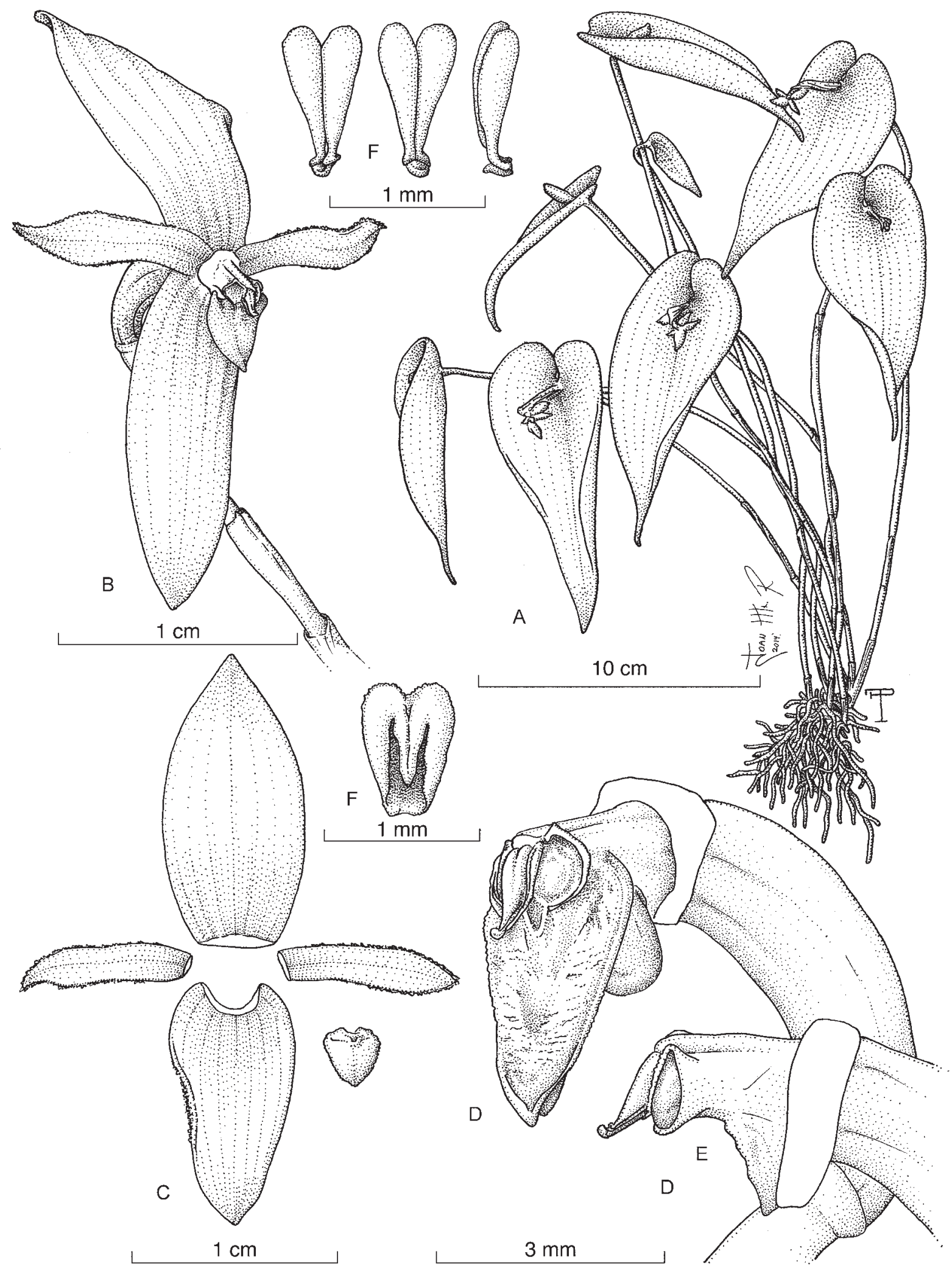

FIGURE 45. Pleurothallis phyllocardia Rchb.f. A, habit; B, flower; C, dissected perianth; D, apex of ovary, column, and lip in three-quarter view; E, column, lateral view; F, anther cap; G, pollinarium (three views). Drawn by F. Pupulin and J. M. Ramírez from Bogarín 7355 (JBL). 
subfalcate, acute, bent backward throughout anthesis, the margins ciliate, 8-9 × 1-2 mm, 3-veined. Lip unguiculate, hinged to the column foot, geniculate, deltoid, basally bilobulate, obtuse, $3.5 \times 2.5 \mathrm{~mm}$, verrucose on the adaxial surface of the apical half, minutely papilose on the margins and around the glenion; glenion recessed between the basal lobes of the lip, ca. $1 \mathrm{~mm}$ long. Column short, transversely subrectangular, dorsiventrally complanate, ca. $2 \times 1 \mathrm{~mm}$, the anther apical, bent, the stigma apical, bilobed. Anther cap obcordate, truncate, bilobed at the base, 2-celled. Pollinia 2, narrowly oblong-pyriform, attached to an elliptic viscidium through a short, cylindric caudicula. Fig. 41F-H.

Etymology: from the Greek words $\phi \breve{v}^{\prime} \lambda \lambda o v$ (phúllon),

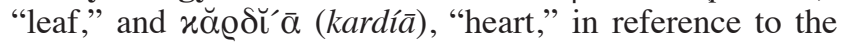
heart-shaped leaves of the species.

Distribution: known from southern Costa Rica and western Panama at 1300-2500 $\mathrm{m}$ in elevation.

Ecology: in Costa Rica, populations of Pleurothallis phyllocardia have been recorded from the premontane and lower montane wet forest of the Cordillera Volcánica Central and Cordillera de Talamanca, where the species inhabits both watersheds at elevations of 1200 to $2300 \mathrm{~m}$. Plants have been recorded in flower from October to February, and from April to June.

Distinguishing features: Pleurothallis phyllocardia is recognized by the glabrous flowers born from an erect bract with the peduncle bent downward, reclining the flowers toward the leaves, and the linear-oblong petals. The most similar species are $P$. pudica and $P$. triangulabia, but the former has a much smaller habit, rounder, flat flowers with the dorsal sepal subequal to narrower than the synsepal, shorter, elliptic petals, and a transversely rectangular lip, while the latter has pubescent-hirsute flowers, with reflexed margins of the sepals, and angulate deflexed shape of the petals.

Costa Rican material examined: Cartago: Jiménez, Pejibaye, Fila Alto Velo de Novia, 9.7736111, -83.7833333, 1300-1700 m, 22 Apr 2006, J. F. Morales Quirós 13806 \& D. Santamaría (CR). Jiménez, Pejibaye, Fila Alto Velo de Novia, 9.7736111, -83.7833333, 1300-1700 m, 22 Apr 2006, J. F. Morales Quirós 13806 \& D. Santamaría (CR). Paraíso, Orosi, P. N. Tapantí, entre Quebrada Segundo y Patillos, 9.7583333, -83.7861111, 1300-1400 m, 17 June 2005, J. F. Morales Quirós 13188 (CR). Paraíso, Orosi, P.N. Tapantí-Macizo Cerro de la Muerte. Camino principal que conduce a las instalaciones del ICE. Bosque húmedo premontano, 9.7500000, -83.7833333, ca. 1400 m, 27 Apr 2007, A. Quesada Hernández 141 (CR). Orosi, Parque Nacional Tapantí, en árboles caídos en sendero, 1280 m, 6 Feb. 2000, F. Pupulin 1981 (JBL). Turrialba, Tayutic, Vereh, siguiendo la fila entre Ríos Vereh y Jicotea, 9.7750000, -83.5444444, 26 Jul 1995, G. Herrera 8121 \& A. Cascante Marín (CR). Turrialba, Tayutic, Grano de Oro. Moravia de Chirripo, 9.8194444, -83.4583333, 1110 m, 29 Jun 1993, $P$. Campos 87 (CR). Turrialba, Tayutic, La Laguna, Quetzal. Grano de Oro. Moravia de Chirripó, Area protegida R.I. Chirripó, 9.7972222, -83.4305556, 1400 m, 20 Jun 2007, P. Campos 119 (CR). Heredia: Barva, San José de la
Montaña, Forêts du Rancho Flores. Massif du Barva, 10.1012950, -84.1199790, 22 Feb 1890, H. F. Pittier 3055 (CR). San Rafael, camino al Monte de La Cruz, desviación al Residencial El Tirol, orillas del Río Segundo, $10^{\circ} 04^{\prime} 27^{\prime \prime N}$, 84 05'08"W, 1800 m, 17 Apr. 2003, D. Bogarín 169 (JBL). Santa Bárbara, Santo Domingo, Pasture above Los Cartagos, slopes of Barva Volcano, 10.1497750, -84.1529560, 31 Aug 1969, R. W. Lent 1775 (CR). Sarapiquí, La Virgen, P.N. Braulio Carrillo, Primary forest between Río Peje and Río Sardinalito. Atlantic slope of Río Volcán Barva, 10.2833333, -84.0666667, 5 Apr 1986, M. H. Grayum 6791 \& A. C. Jermy (CR). Limón: Talamanca, Bratsi, Amubri, Alto Lari, Kivut. Cuenca superior del Rio Dapari. R.I. Talamanca. 9.4041667, -83.0916667, 1200 m, 9 mar 1992, G. Herrera 5252 (CR). Talamanca, Bratsi, P.N. La Amistad Caribe, Sector La Fila, $300 \mathrm{~m}$ antes de union Quebrada Kuisa con R. Lori. Entre Ujarras-San Jose Cabecar, 9.3597222, -83.2291667, 18001843 m, 21 Feb 2007, D. Solano 3916 \& A. Rodríguez G. (CR). Talamanca, Bratsi, P.N. La Amistad Caribe, Valle del Silencio, dentro del jardín. Colectado en bosque, 9.1608333, -82.9844444, 2500-2600 m, 25 Jun 2003, E. Alfaro 4687, M. Alfaro \& R. Delgado (CR). Talamanca, Parque Internacional La Amistad (PILA), sector Altamira, Valle del Silencio, entre cerro Quemado y la División Continental, epífitas en bosque primario, bosque pluvial montano, 2200-2500 m, 17 Sept. 2014, M. Fernández 936, M. Díaz, C. Godínez, A. P. Karremans, L. Oses, J. Ramírez. \& D. Villalobos (JBL). Talamanca, Telire, P.I. La Amistad. Cordillera de Talamanca. Fila arriba unión de ríos Lori y Coén. Entre Ujarrás y San José Cabécar, en sotobosque, 9.4097222, -83.2277778, 29 Mar 1993, A. Fernández 914 \& W. Gamboa (CR). Talamanca, Telire, P. I. La Amistad. Cuenca del Sixaola. Bratsi, sendero Transtalamanca. Entre Ujarrás y San José Cabécar. Alrededores del Río Lori, 9.3537800, -83.2220000, 25 Feb 2007, A. Rodríguez. González 10810 et al. (CR). Valle La Estrella, Fila Matama. Ca. 11 km SW del Pueblo de Aguas Zarcas, 9.8018056, -83.1747992,1300-1400 m,27 Oct 2007, A. Rodríguez. G.et al. 11538 (CR). Puntarenas: Biolley. Parque Internacional La Amistad-Pacífico, sendero hacia Valle del Silencio, después del Cerro Quemado, bosque pluvial montano bajo, bosque primario. Terrestre, a media luz, en suelo drenado, pedregoso, 9 $04^{\prime} 10.88^{\prime \prime} \mathrm{N}, 82^{\circ} 58^{\prime} 45.77^{\prime \prime O}, 2220 \mathrm{M}, 30 \mathrm{Jan}$ 2018, I. Chinchilla 3546, J. E. Jiménez Vargas, J. Porras Quirós \& M. Cedeño Fonseca (JBL). Buenos Aires, Potrero Grande, Tres Colinas. 2-3 km de Tres Colinas. Cercanías del sendero a Cerro Kámuk, Herbazal arbolado de 5-15 m, 9.1381597, -83.0701089, 2000-2100 m, 28 Feb 2008, D. Solano 5224, D. Santamaría \& N. Veas Ayala (CR). Buenos Aires, Potrero Grande, Altamira, Parque Internacional La Amistad, Sector Altamira, Sendero al Valle del Silencio, Cerro Frantzius, bosque pluvial montano bajo, $9^{\circ} 03^{\prime} 31.8^{\prime \prime} \mathrm{N}$, 8259'10.6"W, 2081 m, 30 Aug. 2011, D. Bogarín \& A. Karremans 9090 (JBL); same locality and date, $D$. Bogarín \& A. Karremans 9134 (JBL). Coto Brus, Parque Pittier, June 1995, G. Carnevali s.n. (JBL). Coto Brus, Pittier, Z.P. Las Tablas, Fila del Cerro Gemelo, cerca Finca Chinchilla, 9.0347222, -82.9336111, 2100 m, 17 Sep 1996, 
J. F. Morales Quirós 5813 (CR). Coto Brus, Parque Pittier, June 1995, G. Carnevali s.n. (JBL). Coto Brus, P.N. La Amistad Pacifico, Estación Pittier, 9.0401286, -82.9610786, 1550-1900 m, 8 Jun 1995, A. Angulo 337 (CR). Coto Brus, Sabalito, P.I. La Amistad, Z. P. las Tablas, E.B. Las Alturas de Coton, 8.9500000, -82.8325000, 8 Jul 1994, W. J. Kress 94-3891 \& R. Calderón (CR). Coto Brus, Sabalito, P.I. La Amistad, Z. P. Las Tablas, forested upper slopes of Cerro Burú, Oak forest with Chusquea understory, near Quebrada, 9.0000000, -82.8166667, 20 Aug 1983, G. Davidse 23793 et al. (CR). Coto Brus, Sabalito, Z.P. Las Tablas, Sendero a Cerro Echandi. Bosque primario, 8.9864814, -82.8199911, 2180-2230 m, 19 Nov 1997, B. Gamboa R. 1955 (CR). Parrita, Sector El Chayote, entrando por Lourdes, Chirraca Abajo, de Chirraca Abajo $1 \mathrm{~km}$ SO, 9.6010836, -84.3522081, 2050 m, 16 Aug 2000, A. Rodríguez G. 6185 \& V. Ramirez (CR). San José: Dota, Copey, R. F. Los Santos Pacífico, Providencia. Zapotal. Camino principal a la casa, 9.5372222, -83.8383333, 21 Aug 2003, S. Lobo Cabezas 558 \& A. Ruiz-Boyer (CR). Pérez Zeledón, R.F. Los Santos, Páramo, 9.5038889, -83.8194444, 1700-1800 m, 8 Mar 2001, A. Quesada 557 (CR). Pérez Zeledón, R.F. Los Santos, Páramo, Río Savegre, sendero a Catarata Escondida, 9.5416667, -83.8166667, 2100-2200 m, 22 Jun 2004, J. F. Morales Quirós 10828 (CR). Without collecting data: $J B L-08730$ (JBL). Map 5.

25. Pleurothallis pudica Pupulin, J. Aguilar \& M. Díaz, Lankesteriana 17(2): 154. 2017. TYPE: Costa Rica. San José: Pérez Zeledón, Paramo, Los Ángeles, sobre el camino a San Gerardo de Dota, montañas al norte del río División, en línea con el centro de Los Ángeles, 1700 m, 9 $29^{\prime} 55^{\prime \prime N}$, $83^{\circ} 47^{\prime} 46^{\prime \prime} \mathrm{W}$, bosque pluvial premontano, terrestre a orillas del camino dentro del bosque, con 29 mayo 2014, A. P. Karremans 6249, G. Meza y L. Oses (Holotype: JBL; Isotypes: JBL). Fig. 46 (Voucher, Karremans 6249, JBL).

Epiphytic, caespitose, erect herb to $27 \mathrm{~cm}$ tall. Roots slender, flexuous, ca. $1 \mathrm{~mm}$ in diam. Ramicauls terete, slender, 16.0-26.5 cm long, $0.15-0.20 \mathrm{~cm}$ in diam., pale green, provided with 2 basal, tubular, obtuse sheaths of different size, the lower one loose, the upper tightly clasping, $1.2-1.3$ and $1.5-2.0 \mathrm{~cm}$ long, and a sub-basal, tubular, obtuse, tight sheath $3.8-4.5 \mathrm{~cm}$ long, the sheaths dry-papyraceous, brown. Leaf borne at the apex of the ramicaul, reclinate toward the stem, thinly coriaceous, flexible, sessile, ovate, acute, shortly subacuminate, $5.3-8.2 \times 3.3-5.0 \mathrm{~cm}$, deeply cordate at the base, the basal lobes sometimes overlapping, green, matte. Inflorescence a solitary flower, from an erect, rectangular-clavate, truncate, spathaceous bract $1.1-2.2 \mathrm{~cm}$ long, glumaceous, green, becoming brown, dry-papyraceous when mature. Pedicel terete, green, to $2.2 \mathrm{~cm}$ long. Ovary terete, curved-geniculate, 6-7 mm long. Flowers spreading, reclined toward the leaf, nonresupinate, the sepals purple red, the petals and lip dark purple, pubescent-tomentose abaxially. Dorsal sepal erect, elliptic-lanceolate, acute, 9-10 × 4.5-5.0 mm, 3-veined, pubescent-tomentose, more densely so toward the apex, the trichomes white, translucent. Lateral sepals connate into an ovate, subobtuse synsepal, the margins slightly reflexed, pubescent-tomentose, distinctly shorter than the dorsal sepal, $7.0 \times 4.5 \mathrm{~mm}, 5$-veined. Petals narrowly lanceolate-ligulate, subporrect, acute, ciliate, 7.0 $\times 1.8-2.0 \mathrm{~mm}, 1$-veined. Lip unguiculate, hinged to the column foot, strongly geniculate, broadly ovate-triangular, basally truncate with obtuse angles, broadly obtuse, minutely apiculate, the margins glandulose, the basal margins erect, $2.3 \times 3.0 \mathrm{~mm}$, covered with coarse papillae at the base; glenion raised on a thick callus on the disc ca. 0.4 $\mathrm{mm}$ long. Column short, stout, transversely subrectangular, dorsiventrally complanate, ca. $3.5 \times 3.0 \mathrm{~mm}$, the anther apical, incumbent, the stigma apical, bilobed. Anther cap cucullate, ovate, subcordate, truncate, 2-celled, ca. $0.8 \times$ $0.6 \mathrm{~mm}$. Pollinia 2 , narrowly ovate-pyriform, $0.8 \mathrm{~mm}$ long, attached to an elliptic viscidium. Fig. 41I.

Etymology: from the Latin pudicus, "chaste, modest, shamefaced," in reference to the habit of turning the face of the flower toward the leaf, hiding it from the view of the observer.

Distribution: endemic to central Costa Rica, from the Pacific slopes of the Cordillera de Talamanca.

Ecology: the only known specimen was found growing among mosses on a road cut within a montane forest at about $1700 \mathrm{~m}$ in elevation. Flowering occurs at least in June and July.

Distinguishing features: Pleurothallis pudica is easily recognized among the species of the group by the tomentose flowers facing down and reclinate over the leaf.

Pleurothalis pudica is close to P. scitula from Panama, another member of the P. phyllocardia group that is currently known only from the slopes of Cerro Hornito, in the western region of Chiriquí. Luer (1977) compared $P$. scitula with $P$. phyllocardia, noting that the flowers are pubescent and not deflexed, but facing straight outward. Pleurothalis scitula mainly differs from P. pudica for the resupinate flower (vs. nonresupinate) facing outward (vs. facing the leaf), yellow with bold red stripes (vs. concolorous dark purple), the shorter and broader sepals, and the ovate lip (vs. triangularsagittate).

26. Pleurothallis radula Luer, Selbyana 5(2): 177-178. 1979. Zosterophyllanthos radula (Luer) Szlach. \& Marg, Polish Bot. J. 46(2): 120. 2001[2002]. Acronia radula (Luer) Luer, Monogr. Syst. Bot. Missouri Bot. Gard. 103: 179. 2005. TYPE: Costa Rica. [Cartago]: terrestrial and epiphytic in cloud forest south of Cartago near San Cristobal, alt. ca. 1900 m, 22 Sept. 1979, C. Luer 4251, J.Luer \& K.S. Walter (Holotype: SEL). Fig. 47 (Voucher, Pupulin 8129, JBL).

Epiphytic, rarely terrestrial, caespitose, erect herb, up to $50 \mathrm{~cm}$ tall. Roots slender, flexuous, ca. $1 \mathrm{~mm}$ in diam. Ramicauls terete, slender, 6-50 cm long, 1-3 mm in diam., pale green, with 2 basal, tubular, obtuse sheaths, $0.5-2.5 \mathrm{~cm}$ long, and a longer, sub-basal, tubular, obtuse, tight sheath to $6.5 \mathrm{~cm}$ long, glumaceous, pale green, sometimes spotted purple when young, aging dry-papyraceous, brown. Leaf borne at the apex of the ramicaul, horizontal to deflexed toward the stem, thinly coriaceous, flexible, sessile, lanceolate to ovate, acute to shortly acuminate, $8-19 \times 4-6$ 


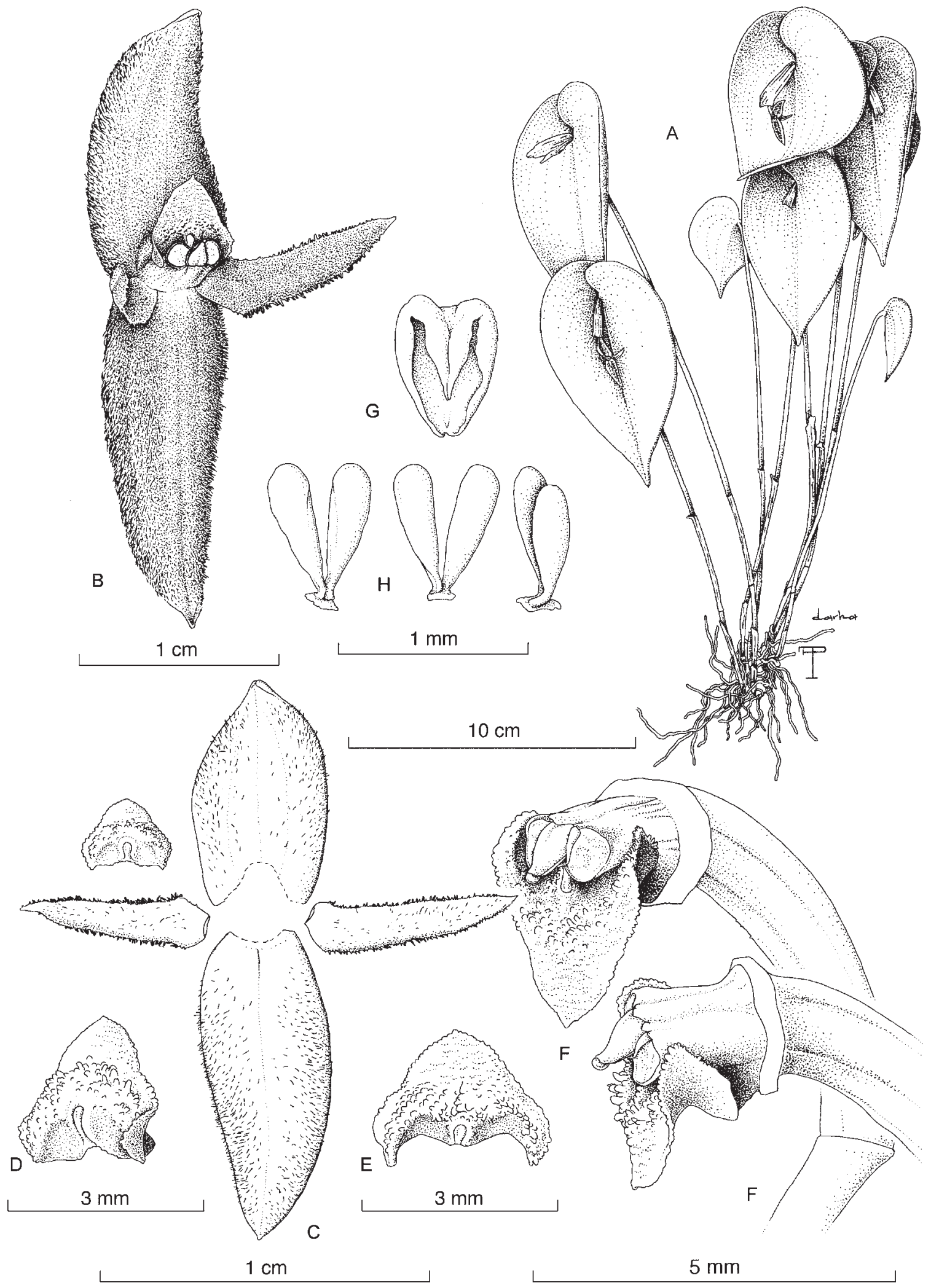

Figure 46. Pleurothallis pudica Pupulin, J. Aguilar \& M. Díaz. A, habit; B, flower; C, dissected perianth; D, lip, three-quarter view; E, lip, adaxial view; $\mathbf{F}$, apex of ovary, column, and lip in three-quarter and lateral views; $\mathbf{G}$, anther cap; $\mathbf{H}$, pollinarium (three views). Drawn by F. Pupulin and D. Solano Ulate from Karremans 6249 (JBL). Reproduced with permission from the Editor of Lankesteriana. 


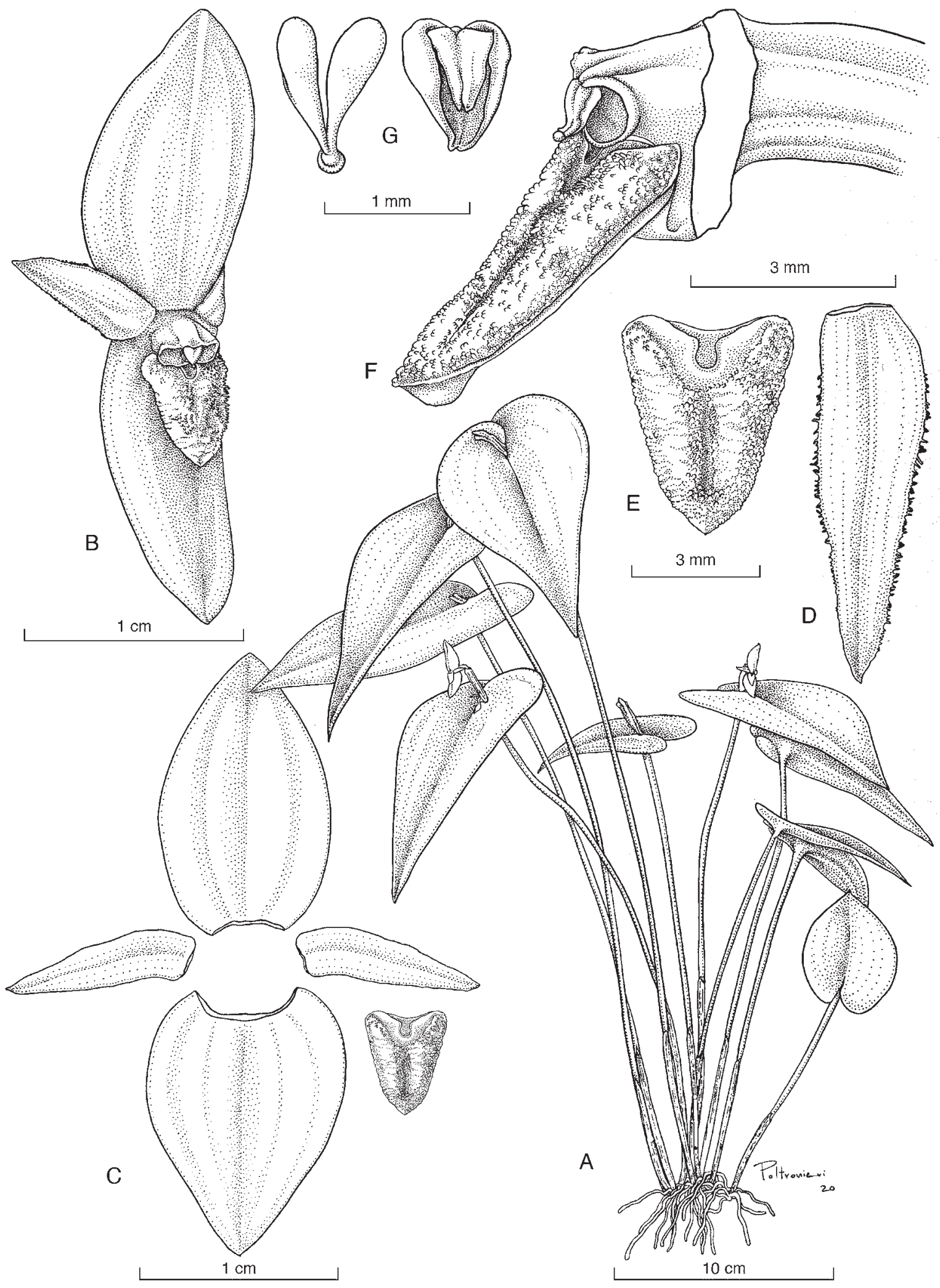

FIgURE 47. Pleurothallis radula Luer. A, habit; B, flower; C, dissected perianth; D, left petal; E, lip, adaxial view; F, apex of ovary, column, and lip in lateral view; G, pollinarium and anther cap. Drawn by F. Pupulin and S. Díaz Poltronieri from Pupulin 8129 (JBL). 
$\mathrm{cm}$, deeply cordate at the base, the basal lobes overlapping or not, the margins incurved, matte, green, sometimes sparsely spotted to boldly blotched purple along the margins; immature leaf narrowly elliptic-lanceolate, the base cuneate. Inflorescence a solitary flower, born from an erect, oblanceolate, subtruncate, spathaceous bract at the base of the leaf, to $27 \times 8 \mathrm{~mm}$, glumaceous, green, sometimes finely flecked with purple, becoming brown, dry-papyraceous with age, concealing peduncle, pedicel and floral bract. Peduncle terete, 6-8 $\mathrm{mm}$ long. Floral bract triangular, 3-5 mm long. Pedicel terete, green, 8-14 mm long, completely hidden within the spathe. Ovary terete-subclavate, curved, 4-6 mm long. Flowers spreading-reflexed, yellow, rarely with the sepals tinged rose toward the apices, the lip pale orange, the column greenish white. Dorsal sepal erect, ovate to ovateelliptic, subacute to acute, $12-14 \times 6-8 \mathrm{~mm}$, the margins revolute, 3 -veined. Lateral sepals connate into a narrowly ovate-lanceolate to ovate, subobtuse to acute, synsepal, sometimes shortly bifid at apex, the margins reflexed, 12$14 \times 7 \mathrm{~mm}$, each half 2-veined. Petals narrowly lanceolate, acute, serrate, reflexed, 8.0-9.5 × $2.0 \mathrm{~mm}$, single-veined. Lip unguiculate, hinged to the column foot, thick and fleshy, peltate, basally cordate with rounded angles, acute, $4.5 \times 3.2 \mathrm{~mm}$, densely long papillose-verruculose except for the area around the glenion, the papillae irregularly coarse, the abaxial side smooth; glenion slowly raised on a glabrous callus on the disc, $1 \mathrm{~mm}$ long. Column short, stout, transversely subrectangular, dorsiventrally complanate, ca. $2 \times 2 \mathrm{~mm}$, with a foot $1.8 \mathrm{~mm}$ long, the anther apical, incumbent, the stigma apical, bilobed. Anther cap cucullate, ovate, subcordate, 2 -celled, $0.8 \times 0.6 \mathrm{~mm}$. Pollinia 2 , ovatecomplanate, apically attenuate into cylindrical caudicules, $0.8 \mathrm{~mm}$ long, attached to a round viscidium. Fig. 48A-C.

Etymology: from the Latin radula, "a rasp," in allusion to the markedly verrucose lip.

Distribution: endemic to Central Costa Rica.

Ecology: epiphytic or terrestrial in lower montane wet forest of the Pacific watershed between 1900 and $2150 \mathrm{~m}$. Flowering has been recorded from March to May, and from August to November.

Distinguishing features: Pleurothallis radula can be distinguished by the concolorous yellow flower borne at the apex of an erect spathe, with the margins of the sepals revolute and the serrate petals strongly reflexed.

Interestingly, the color dimorphism that is fairly common in species of Pleurothallis with tall vegetative habit, which frequently presents both solid purple and solid yellow forms, and sometimes a spectrum of intermediate color forms with both purple and yellow coloration, often intermixed in the same populations, is unknown in the group of $P$. phyllocardia. In this group, almost all the species have solid purple flowers to boldly purple, except for P. radula, whose flowers are concolorous yellow (rarely with the sepals tinged rose toward the apices). This makes the species unmistakable.

Costa Rican material examined: Cartago: near San Cristóbal, ca. 1900 m, 22 Sep 1979, C. Luer 4251, J. Luer \& K. S. Walter (SEL). San Francisco, Muñeco, Finca Loma Verde y Jilguero, camino a Alto Belén, entre Río Sombrero y Quebrada Patarrá, 946'50.3"N, 835'21.1"W, 1430$1620 \mathrm{~m}$, bosque pluvial premontano, epífitas en bosque secundario y árboles en zonas abiertas, 23 May 2007, D. Bogarín 3872, M. Bonilla, R. Gómez, Rafael Trejos \& J. D. Zúñiga (JBL). Jiménez, Pejibaye, Estación Biológica Copal, Instalaciones, en el sendero Ron Ron y hacia el albergue, 9.7834072, -83.7519294, 1000-1100 m, 10 June 2005, D. Solano 2506 (CR). Jiménez, Pejibaye, Alto del Humo, 23 mayo 2005, R. L. Dressler 6565 (JBL). San Francisco, Navarro, Muñeco, Fincas Loma Verde y Jilguero, camino a Alto Belén, entre Río Sombrero y Quebrada Patarrá, $9^{\circ} 46^{\prime} 50.3^{\prime \prime} \mathrm{N}, 83^{\circ} 54^{\prime} 21.1^{\prime \prime O}, 1430-1620 \mathrm{~m}$, bosque pluvial premontano, bosque secundario y orillas de caminos, 23 May 2007, J. D. Zúñiga 178, D. Bogarín, M. Bonilla, R. Gómez, R. L. Dressler y R. Trejos (JBL). Jiménez, Pejibaye, entre Tausito y Selva, alrededores de la Reserva Biológica El Copal, orillas del Río Taus y Quebrada Selva, 947'5.22"N, $83^{\circ} 45^{\prime} 46.1^{\prime \prime} \mathrm{W}, 1197 \mathrm{~m}$, bosque pluvial premontano, epífitas en bosque secundario a orillas del camino, 1 May 2008, $D$. Bogarín 4767, A. Karremans, Y. Kisel \& R. Phillips (JBL). Jiménez, Pejibaye, Tucurrique, Bajos del Humo, entre ríos Humo y Vueltas, ladera este de Cerros Duán, 948'36.7"N, $83^{\circ} 45^{\prime} 16.2^{\prime \prime} \mathrm{W}, 1396 \mathrm{~m}$, bosque pluvial montano bajo, epífitas en árboles en potreros y borde de bosque, 24 Nov 2008, D. Bogarín 5710, R. L. Dressler, R. Gómez \& R. Trejos (JBL); same collecting data, D. Bogarín 5716, R. L. Dressler, $R$. Gómez \& R. Trejos (JBL). San Francisco, Muñeco, Navarro, from the square $7 \mathrm{~km}$ toward Alto Belén, 945'50.3"N, $83^{\circ} 54 ' 21.1^{\prime \prime} \mathrm{W}, 1900 \mathrm{~m}$, premontane rain forest, epiphytic in altered vegetation, collected by Daniel Jiménez, 31 Oct 2008, flowered in cultivation at Lankester Botanical Garden, 15 Nov 2011, F. Pupulin 8130 (JBL). El Guarco, Patio de Agua, Finca Integral Fractal, 947'48"N, 84 00'02"W, 2048 $\mathrm{m}$, bosque pluvial montano bajo, en rama caída dentro de un parche de bosque maduro, con flores amarillas teñidas de rosado, 7 Aug 2020, N. Belfort-Oconitrillo $569 \&$ \&. Calderón (JBL). San José: León Cortés, Santa Cruz, $9^{\circ} 42^{\prime} 29^{\prime \prime} \mathrm{N}, 84^{\circ} 01^{\prime} 38^{\prime \prime} \mathrm{W}, 2145 \mathrm{~m}$, terrestre, en bosque muy húmedo montano bajo, legit M. L. Gamboa, 26 mayo 2019, M. Díaz 385 (JBL). León Cortés, Santa Cruz, 942'26"N, $84^{\circ} 01^{\prime} 44^{\prime \prime W}, 2140$ m, epífita, en rama caída en bosque muy húmedo montano bajo, legit M. L. Gamboa, 26 mayo 2019, M. Díaz 386 (JBL). Map 5.

27. Pleurothallis rectipetala Ames \& C. Schweinf., Sched. Orch. 8: 32. 1925. Acronia rectipetala (Ames \& C. Schweinf.) Luer, Monogr. Syst. Bot. Missouri Bot. Gard. 103: 180. 2005. Zosterophyllanthos rectipetalus (Ames \& C. Schweinf.) Szlach. \& Kulak, Richardiana 6: 192. 2006. TYPE: Costa Rica. [Cartago:] Cachí, cultivated at Cartago and flowered in Jun 1924, C. H. Lankester 915 (Holotype: AMES). Fig. 49-50 (Vouchers, Bogarín 5743, Bogarín 8855, JBL).

Epiphytic, caespitose, erect herb, up to $30 \mathrm{~cm}$ tall. Roots slender, flexuous, ca. $1 \mathrm{~mm}$ in diam. Ramicauls terete, slender, 18-29 cm long, 1-2 mm in diam., pale green, with 2 basal, tubular, obtuse sheaths, 1-2 cm long, and a longer, sub-basal, tubular, obtuse, tight sheath 6-7 cm long, the sheaths dry-papyraceous, brown. Leaf borne at the apex of 


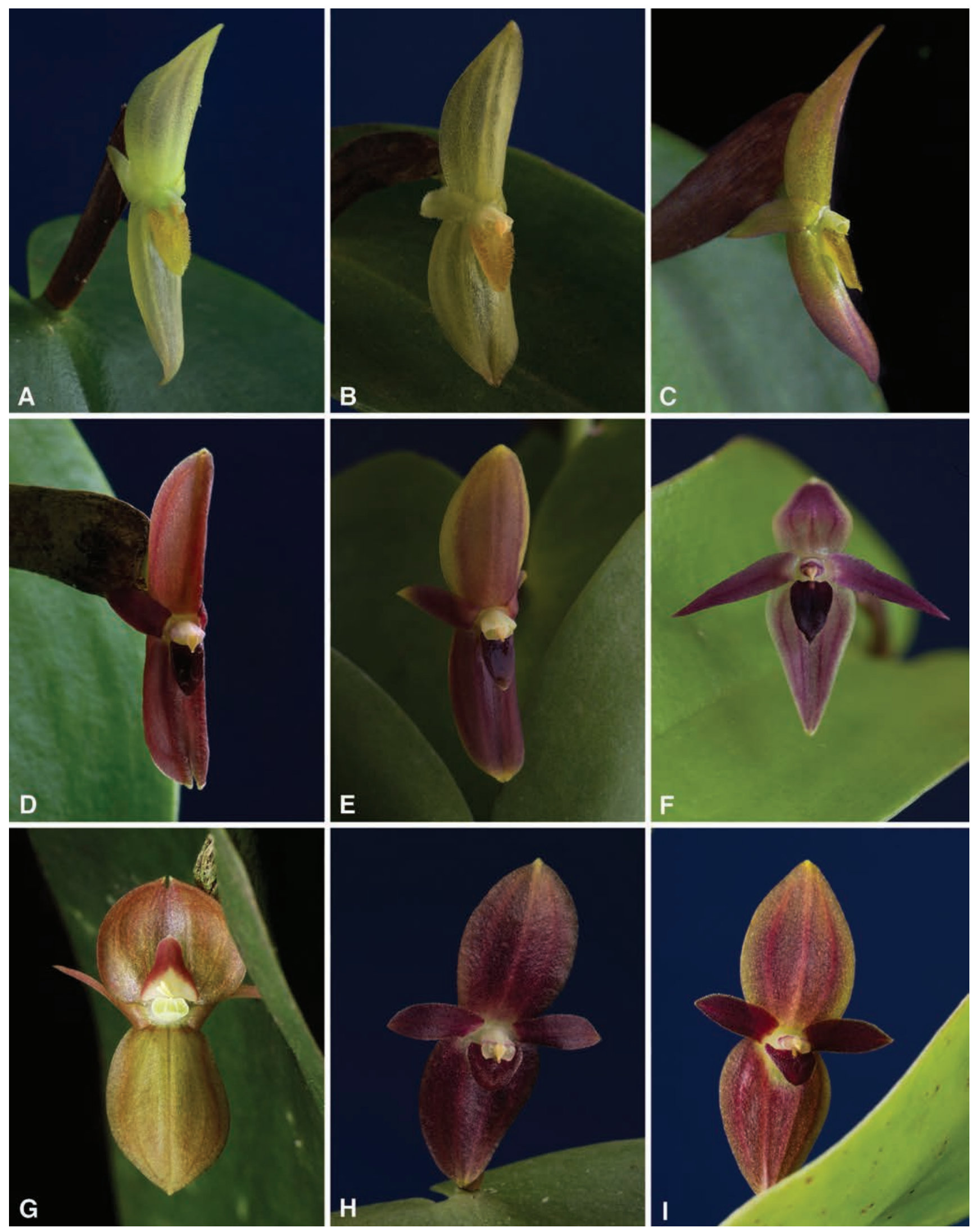

FIGURE 48. A-I, Flowers of Pleurothallis species from Costa Rica in the P. phyllocardia group. A-C, P. radula (Pupulin 7796; Karremans 5162; Belfort-Oconitrillo 569); D-E, P. rectipetala (Dressler 6565; Bogarín 5743); F, P. ×silvae-pacis (Karremans 3069); G, P. ×subversa (Pupulin 8817); H-I, P. triangulabia (Pupulin 8739; Pupulin 8743). Not at the same scale. All the vouchers at JBL. Photographs by F. Pupulin except C (N. Belfort-Oconitrillo) and E (D. Bogarín). 


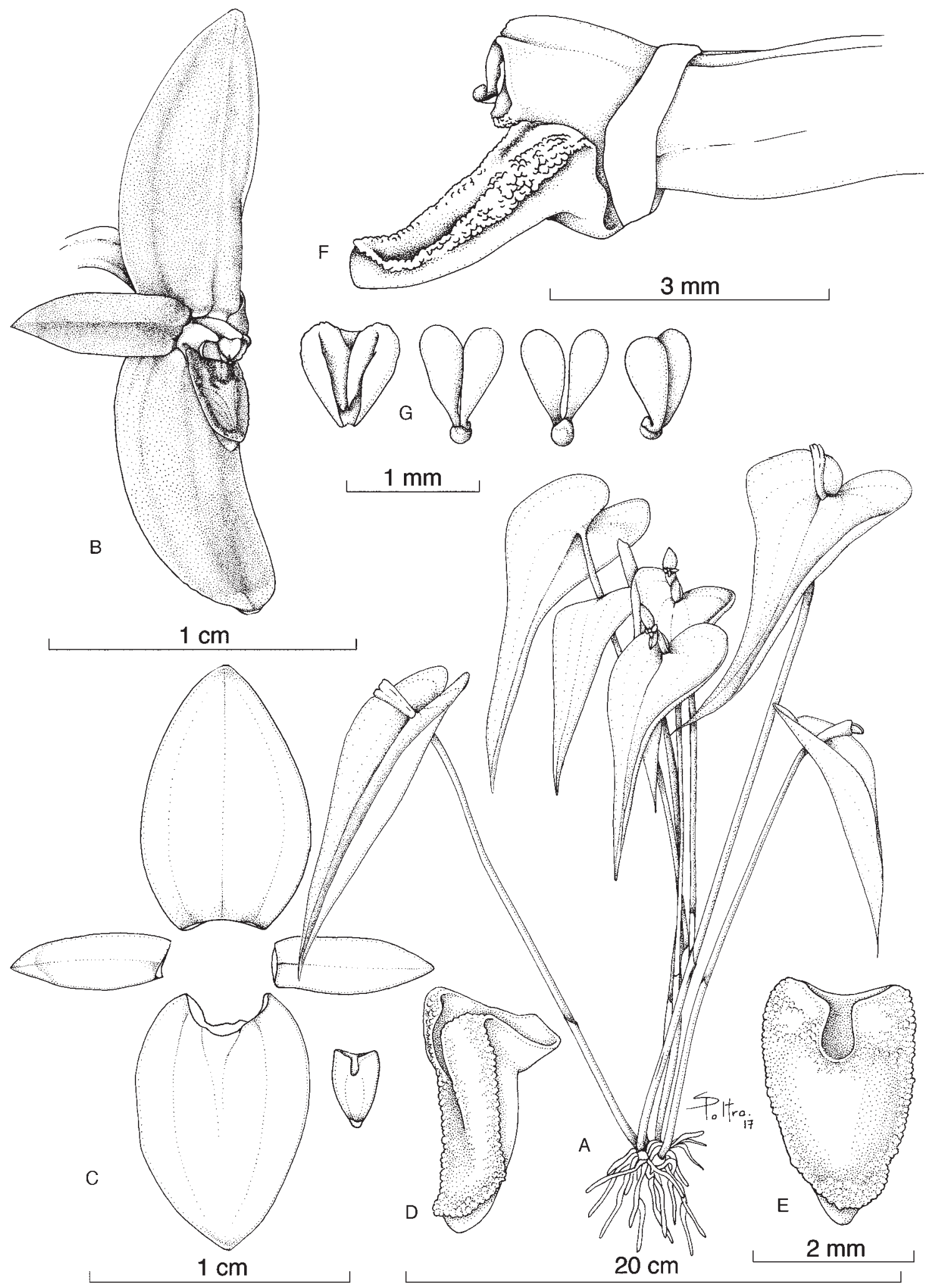

FIgURE 49. Pleurothallis rectipetala Luer. A, habit; B, flower; C, dissected perianth; D, lip, lateral view; E, lip, adaxial view; F, apex of ovary, column, and lip in lateral view; G, anther cap and pollinarium (three views). Drawn by F. Pupulin and S. Poltronieri from Bogarín 8855 (JBL). 


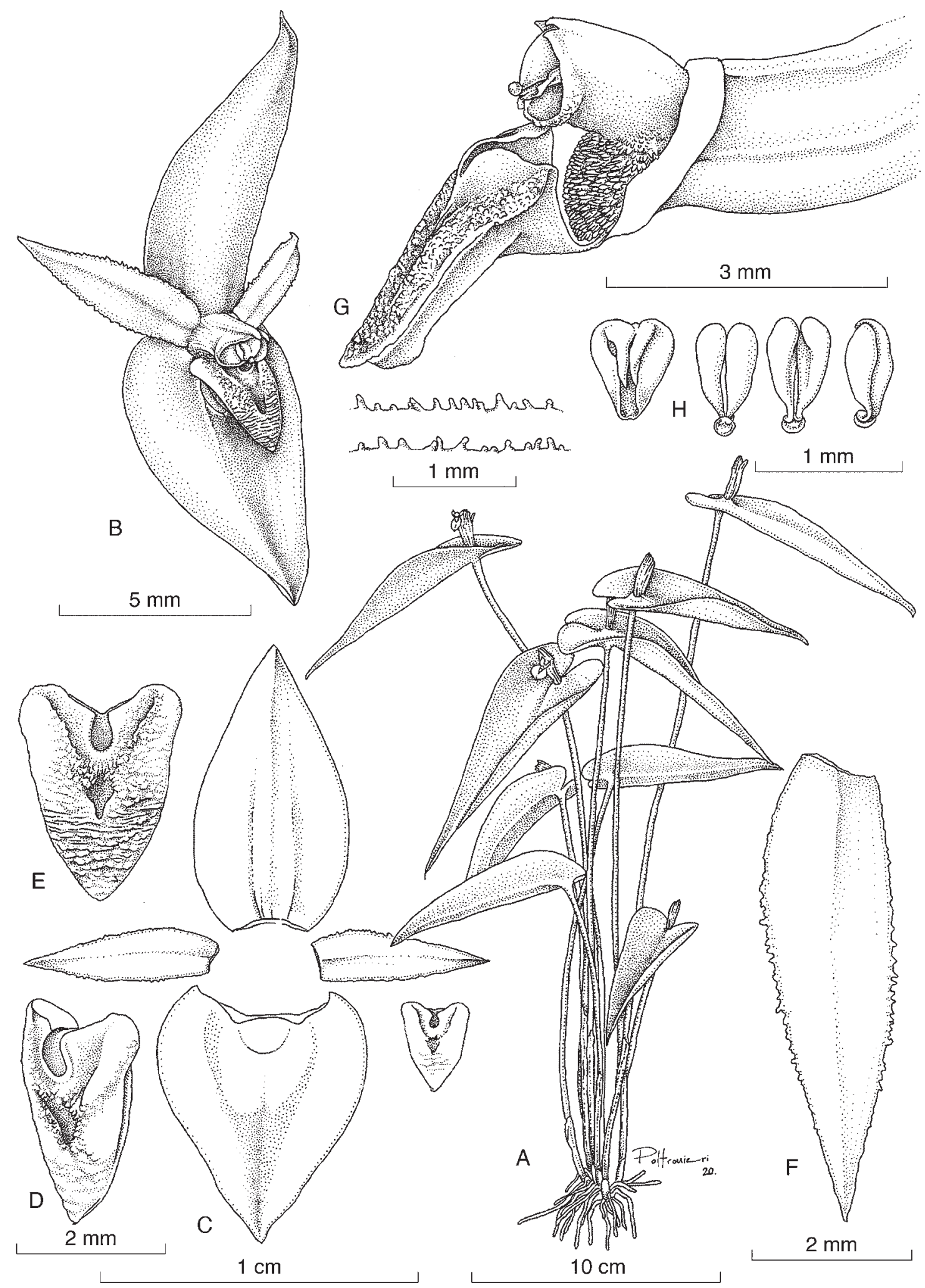

FIgURE 50. Pleurothallis rectipetala Luer. A, habit; B, flower; C, dissected perianth; D, lip, three-quarter view; E, lip, adaxial view; F, right petal; G, apex of ovary, column, and lip in lateral view; H, anther cap and pollinarium (three views). Drawn by F. Pupulin and S. Díaz Poltronieri from Bogarín 5743 (JBL). 
the ramicaul, horizontal to subreclinate toward the stem, thinly coriaceous, flexible, sessile, ovate, acute, shortly subacuminate, 11-14 ×4-7 cm, deeply cordate at the base, the basal lobes not overlapping, the margins incurved, green, matte. Inflorescence a solitary flower, borne from an erect, oblanceolate, rounded to subtruncate, spathaceous bract to $15 \mathrm{~mm}$ long, glumaceous, green, becoming brown, dry-papyraceous when mature. Pedicel terete, green, to ca. $15 \mathrm{~cm}$ long, completely hidden within the spathe. Ovary terete, curved, $5 \mathrm{~mm}$ long. Flowers spreading-reflexed, the sepals dull brownish purple, the dorsal sepal fading greenish yellow toward the margins, the petals purple tinged with yellow apically, the lip purple, the column white. Dorsal sepal erect, broadly elliptic-lanceolate, obtuse, 6-7 $\times 4$ $\mathrm{mm}$, the margins reflexed, 5-veined. Lateral sepals connate into an ovate, subobtuse, apically subexcise synsepal, the margins reflexed, $12 \times 8 \mathrm{~mm}$, each half four-veined. Petals linear-lanceolate to linear-oblong, acute, minutely apiculate, denticulate in the distal third, reflexed at maturity, 5-6 $\times 2$ mm, single-veined. Lip unguiculate, hinged to the column foot, thick and fleshy, ovate-peltate, basally truncate with obtuse angles, obtuse-rounded, the sides smooth, $3 \times 2$ $\mathrm{mm}$, densely papillose throughout, the papillae coarser at the base; glenion raised on a thick, velutine callus on the disc, less than $1 \mathrm{~mm}$ long. Column short, stout, transversely subrectangular, dorsiventrally complanate, with a short foot, ca. $2 \times 2 \mathrm{~mm}$, the anther apical, incumbent, the stigma apical, bilobed. Anther cap cucullate, ovate, subcordate, subtruncate, 2-celled. Pollinia 2, narrowly ovate, apically attenuate, attached to an elliptic viscidium. Fig. 48D-E.

Etymology: from the Latin rectus, "straight," in reference to the shape of the petals, which are linear-lanceolate to linear-oblong, reflexed, and pointing upward.

Distribution: known only from Costa Rica, where it is apparently restricted to the Caribbean watershed in the northern Cordillera de Talamanca.

Ecology: this species has been found growing in primary and secondary forests, as well as on scattered trees in paddocks and forest edges, in premontane and low montane forests, between 1300 and $1450 \mathrm{~m}$ in elevation. Blooming has been recorded in cultivation at least from May to June and in November.

Distinguishing features: Pleurothallis rectipetala can be distinguished by the combination of the comparatively large, cordate leaves, the erect spathe with the flowers barely exerted from it, the dull purple flowers with linear-oblong, reflexed petals, and the very thick, ovate-peltate lip. It is most similar to $P$. radula, which has yellow flowers and an irregularly crestate lip, and to P. luna-crescens, which has a moon crescent-shaped flower with much longer, narrow petals.

Costa Rican material examined: Cartago: Jiménez, Pejibaye, Tucurrique, Bajos del Humo, entre ríos Humo y Vueltas, ladera este de Cerros Duán, 948'36.7"N, $83^{\circ} 45^{\prime} 16.2^{\prime \prime} \mathrm{W}, 1396 \mathrm{~m}$, bosque pluvial montano bajo, epífitas en árboles en potreros y borde de bosque, 24 Nov 2008, D. Bogarín 5743, R. L. Dressler, R. Gómez \& R. Trejos (JBL). Turrialba, La Suiza, Llanos del Quetzal, ca. 1 km sobre el camino detrás de la Escuela de Kabébata (Alto
Quetzal), 946'43.6"N, 83²4'41.6"W, 1449 m, epífitas en bosque primario y secundario, bosque muy húmedo premontano "supra arbores in nemoribus Llanos del Quetzal ad Turrialba in Cartago," 17 junio 2011, D. Bogarín 8855 , M. Fernández \& A. Karremans (JBL). Map 5.

28. Pleurothallis xsilvae-pacis Karremans, Orch. Rev. 121: 156. 2011. (pro sp.). TYPE: Costa Rica. Alajuela: Valverde Vega, Bajos del Toro, Hacienda Río Toro, Bosque de Paz Biological Reserve, 1500-2000 m. Flowered in cultivation in the orchid garden, 25 November 2010, A. P. Karremans 3069 (Holotype: CR; Isotype: JBL-spirit). Fig. 51 (Voucher, Karremans 3069, CR).

Epiphytic, caespitose, erect herb up to $20 \mathrm{~cm}$ tall. Roots slender. Ramicaul cylindric, erect to suberect, up to $18 \mathrm{~cm}$ long, enclosed by a closely adpressed sheath that covers the first third of the ramicaul, with a few sheaths at the base. Leaf horizontal to subhorizontal, coriaceous, narrowly ovate to acuminate, $8-10 \times 2.5 \mathrm{~cm}$, the base sessile, cordate. Inflorescence single-flowered, produced in succession and emerging from a papyraceous, semierect spathe, 14-16 mm long, forming a fascicle of old inflorescences with time. Floral bract 3-4 $\mathrm{mm}$ long. Pedicel 8-9 $\mathrm{mm}$ long. Ovary cylindrical, 3-4 $\mathrm{mm}$ long. Flowers with greenish-rose sepals, veins rose, the petals and lip dark rose, the column whitish green. Dorsal sepal ovate-acuminate, obtuse, 9.2 $\times 4 \mathrm{~mm}, 3$-veined. Lateral sepals connate into an ovateacuminate synsepal, $7.5 \times 3.7$ wide, 4 -veined. Petals linearacuminate, somewhat falcate, acute, margins serrulate, 6.7-6.9 × 1.4-1.5 mm, 1-veined. Lip thick, ovate, acute, $3.0-3.2 \times 1.7 \mathrm{~mm}$, the base reflexed as a claw, hinged to the column foot, the lamina provided with a basal glenion, below it rises a conspicuous peak, the apical third of the lamina provided with shallow lateral sinuses. Column thick, $1.2-1.3 \mathrm{~mm}$ long, the foot thick-bulbous, papillose; stigma and anther apical. Pollinia 2, $0.75 \mathrm{~mm}$ long, provided with inconspicuous caudicles, and a hard, bubble-like viscidium. Fig. 48F.

Etymology: from the Latin silva, "forest," and pax-pacis, "peace," honoring the Bosque de Paz (Forest of Peace) Biological Reserve, where the type specimen was collected.

Distribution: known only from Costa Rica, on the Caribbean watershed of the Cordillera Volcánica Central, just north of the Central Valley.

Ecology: in the wild, Pleurothallis $\times$ silvae-pacis grows as an epiphyte in premontane, very humid cloud forests at elevations of 1500-2000 $\mathrm{m}$. The plant has been recorded in flower from September to March.

Distinguishing features: the combination of rather short and narrowly lanceolate, dark green leaves, the flower born on a long peduncle, the sepals and petals tinged with rose on a white background, and the narrowly ovate lip with an imperfect basal glenion distinguishes the nothospecies. The inflorescence with the long pedicel, the orientation of the flowers, the shape of the lip, and the structure of pollinaria suggest an affinity with Pleurothallis eumecocaulon, a species belonging to the group of Pleurothallis "Ancipitia" that has been recorded at the collection locality of the putative hybrid. The larger plant habit, the serrulate petals, 


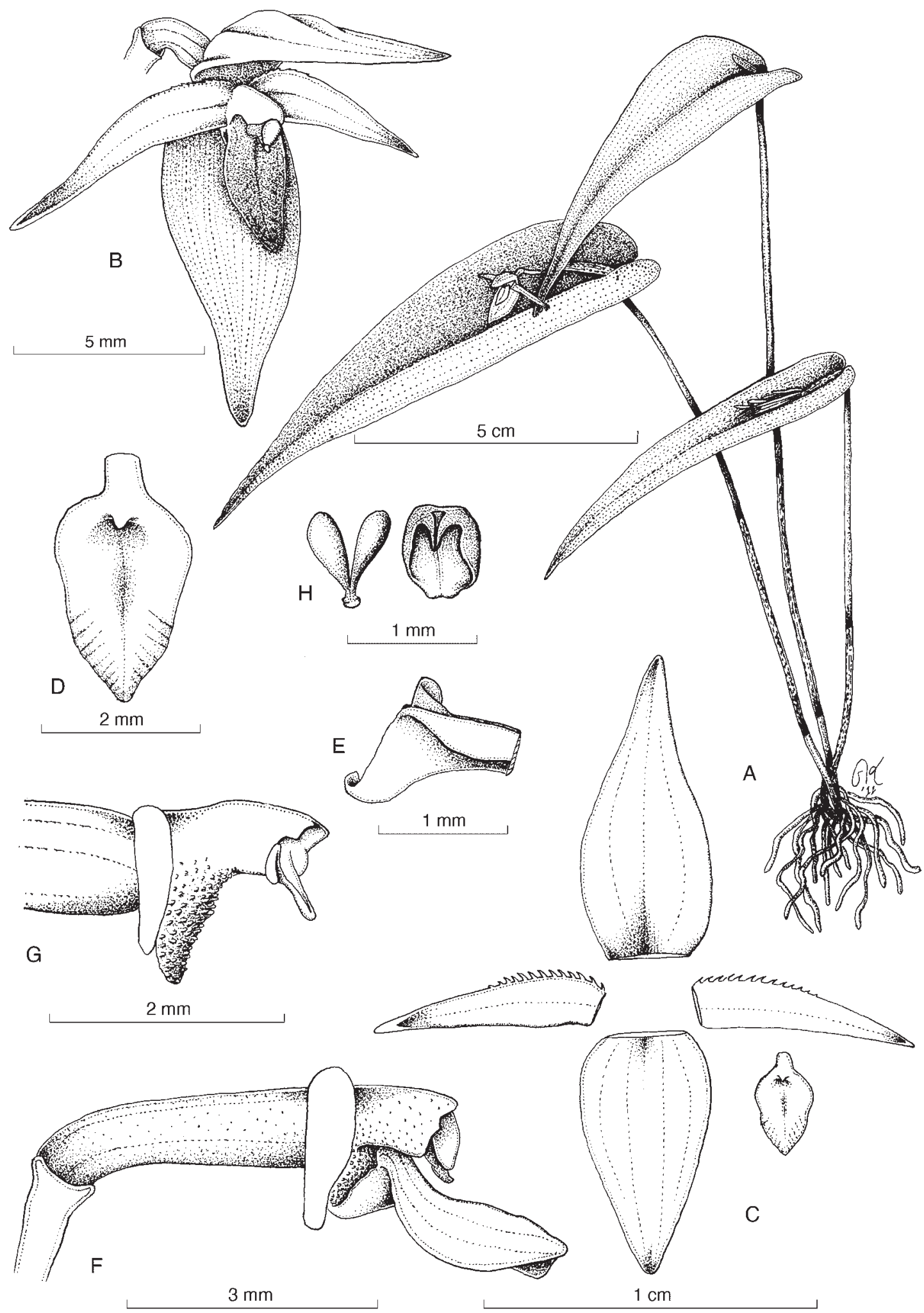

FIGURE 51. Pleurothallis $\times$ silvae-pacis Karremans. A, habit; B, flower; $\mathbf{C}$, dissected perianth; D, lip, adaxial view; E, base of the lip, lateral view; F, ovary, column, and lip in lateral view; G, column, lateral view; H, pollinarium and anther cap. Drawn by A. P. Karremans from Karremans 3069 (CR). From Karremans \& Muñoz García, 2011. 
the lip distinctly geniculate at the base, and the presence of an imperfect glenion at the base of the disc would seem derived from the genetic influence of a species of the Macrophyllae-Fasciculate group, but at our current state of knowledge we cannot speculate about its identity.

We treat here Pleurothallis $\times$ silvae-pacis as a probable nothospecies, from the natural cross between $P$. eumecocaulon and $P$. phyllocardia. Both species have been recorded at the type locality of $P$. $\times$ silvae-pacis, and they are the only members of the $P$. "Ancipitia" (sensu Luer 1986) and $P$. phyllocardia groups (the latter defined in this paper), respectively, that form natural populations at Bosque de Paz. It has features of the group of Pleurothallis species treated like members of "Ancipitia," such as the size of the plant with long acuminate leaves, as well as the presence and accumulation of the senescent pedicels on the leaf, but it shares the unguiculate, purple lip that is typical of taxa belonging to the $P$. phyllocardia group.

Costa Rican material examined: Alajuela: Valverde Vega, Bajos del Toro, Hacienda Río Toro, Bosque de Paz Biological Reserve, 1500-2000 m, BdP 06-242 (BdP, BdPspirit). Map 5.

29. Pleurothallis ×subversa Pupulin \& Bogarín, nothosp. nov.

TYPE: Costa Rica. Cartago: Paraíso, Cachí, ca. 950'N, $83^{\circ} 48^{\prime} \mathrm{W}, 1300 \mathrm{~m}$, collected by D. Jiménez, flowered in cultivation 9 November 2011, F. Pupulin 8817 (Holotype: JBL). Fig. 52 (Voucher, Pupulin 8817, JBL). Map 4.

Pleurothallis nothospecie nova inter P. compressam Luer et quemquam Pleurothallidem turmae cardiothallidis Rchb.f. affinem, fortasse Pleurothallidem oncoglossam Luer, intermedia, folio anguste ovato flore subverso synsepalo orbiculare labello bene triangulo P. compressa similis, ramicaulibus teretibus floribus dimensione alium genitorem reminiscens.

Epiphytic, caespitose, suberect to curved herb, to $30 \mathrm{~cm}$ tall. Roots slender, flexuous, 1-2 $\mathrm{mm}$ in diam. Ramicauls terete throughout, slender, 9-31 cm long, 1.5-2.5 mm in diam., yellowish green, provided with 2 tubular, short, truncate sheath to $2 \mathrm{~cm}$ long at the base, glumaceous, pale green when young, becoming brown, dry-papyraceous with age. Leaf suberect to reclined toward the stem, thinly coriaceous, flexible, sessile, narrowly ovate-lanceolate, acuminate, $11-15.2 \times 4.0-5.4 \mathrm{~cm}$, deeply cordate at the base, the basal lobes not overlapping, sometimes upcurved, grass green, matte. Inflorescence a solitary flower, borne pendent from a suberect, spathaceous, diagonally truncate bract $14 \mathrm{~mm}$ long, brown, dry-papyraceous when mature; peduncle terete, facing down, 9-11 mm long. Pedicel terete, to $5 \mathrm{~mm}$ long. Ovary suclavate, curved, rounded in section, greento bronze-green, $7 \mathrm{~mm}$ long. Flowers nonresupinate, partially reflexed, the sepals reddish yellow to bronze, the petals brownish red, the lip white, flushed bright red toward the apex and the margins, the column white. Dorsal sepal broadly ovate, obtuse, $11 \times 9 \mathrm{~mm}, 5$-veined. Lateral sepals connate into a rounded, obtuse to subtruncate synsepal, 9.5 $\times 10.0 \mathrm{~mm}$, each half 2 -veined. Petals narrowly triangular- falcate, acuminate, $8.0 \times 1.5 \mathrm{~mm}$, 1-veined. Lip hinged to the column foot, triangular, basally truncate with acute angles, obtuse, sparsely verrucose around the glenion, $4 \times$ $4 \mathrm{~mm}$, thickened at the base; glenion raised on a cushionlike callus between the basal lobes of the lip, $1 \mathrm{~mm}$ long. Column short, transversely subrectangular, dorsiventrally complanate, ca. $2 \times 2 \mathrm{~mm}$, apically diagonally truncate, the anther apical, bent, the stigma apical, bilobed. Anther cap cucullate, ovate, cordate, 2-celled. Pollinia 2, narrowly oblong-pyriform, attached to a small. elliptic viscidium through two abbreviate caudicles. Fig. 48G.

Etymology: from the Latin subversus (present perfect of subverto), "subverted, inverted, turned upside down," in reference to the nonresupinate orientation of the flower.

Distribution: known only from the type specimen, collected in Costa Rica (Map 4).

Ecology: epiphytic in premontane rain forest along the Caribbean watershed of the Cordillera de Talamanca, just south of the Central Valley in Costa Rica. The plant has been recorded in flower in November.

Distinguishing features: the relatively large plants with narrowly ovate-lanceolate leaves, cordate at the base, and the large, truly pendent, partially reflexed, nonresupinate flowers with bronze sepals and red petals, provided with a white lip flushed bright red toward the apex and the margins, are diagnostic of Pleuothallis $\times$ subversa.

The thinly coriaceous, narrowly ovate-lanceolate, apically long-acuminate leaves, with the basal margins often slightly incurved, as well as the nonresupinated flower borne at the apex of a truly pendent pedicel and the ovary curved $90^{\circ}$, with the sepals and petals partially reflexed, are strongly reminiscent of $P$. compressa, which we propose here as one of the putative parents of the natural hybrid. The ramicauls, however, are terete throughout, unlike those of $P$. compressa, which become strongly ancipitous toward the apex. The size of the flower is also different, almost double, that of $P$. compressa, and we hypothesize that it is inherited from the other putative parent, likely a large-flowered species close to $P$. cardiothallis. As both $P$. cardiothallis and P.oncoglossa, with flowers over $3 \mathrm{~cm}$ tall, form natural populations in the region where $P$. $\times$ subversa was found, they both should be considered possible parents of the new nothospecies. However, the almost flat sepals are most likely inherited from $P$. oncoglossa, which is common around Cachí where the hybrid was found, and whose flowers remain spread during anthesis, while the sepals of $P$. cardiothallis have strongly swept back margins at maturity.

30. Pleurothallis triangulabia C. Schweinf., Ann. Missouri Bot. Gard. 24(2): 183. 1937.

SYNTYPES: Costa Rica. [Alajuela: Quesada,] arbres des paturages a Palmira de Alfaro Ruiz, 840 m, 4 Jul 1925, fleurs rouge-vineux foncé, A. M. Brenes (138a) 1341 (AMES 43761, selected here as the lectotype). Panama. Chiriquí: valley of the upper Río Chiriquí Viejo, vicinity of Monte Lirio, 1300-1900 m, flowers dark reddish purple, June 27July 13, 1935, R. J. Sibert 269 (MO, not seen]. Fig. 53-54 (Voucher, Pupulin 8739 and Pupulin 8743, both at JBL). 


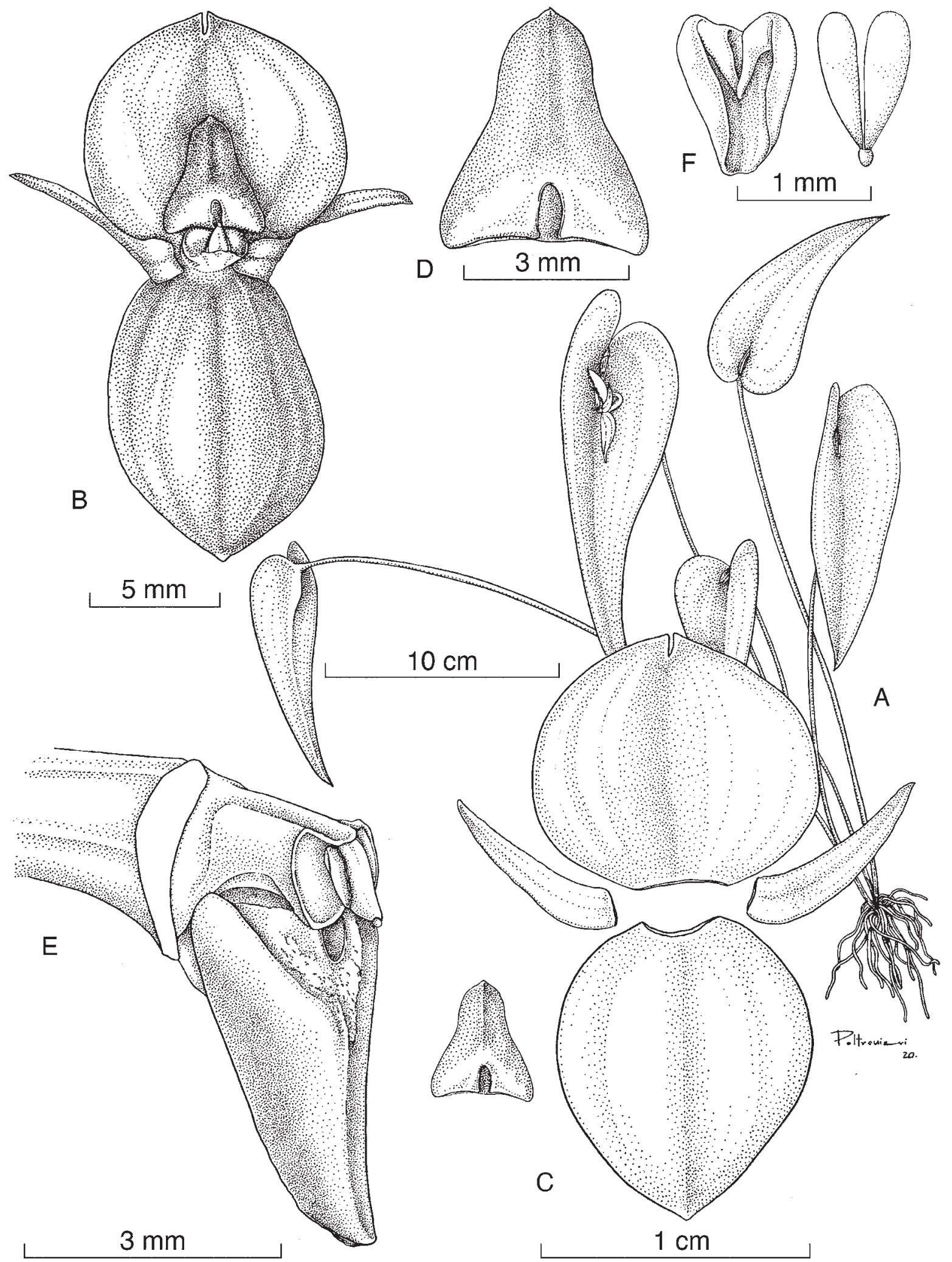

Figure 52. Pleurothallis $\times$ subversa Pupulin \& Bogarín. A, habit; B, flower; C, dissected perianth; D, lip, adaxial view; E, ovary, column, and lip in lateral view; F, anther cap and pollinarium. Drawn by S. Díaz Poltronieri from Pupulin 8817 (JBL). 
VOL. 26, NO. 1

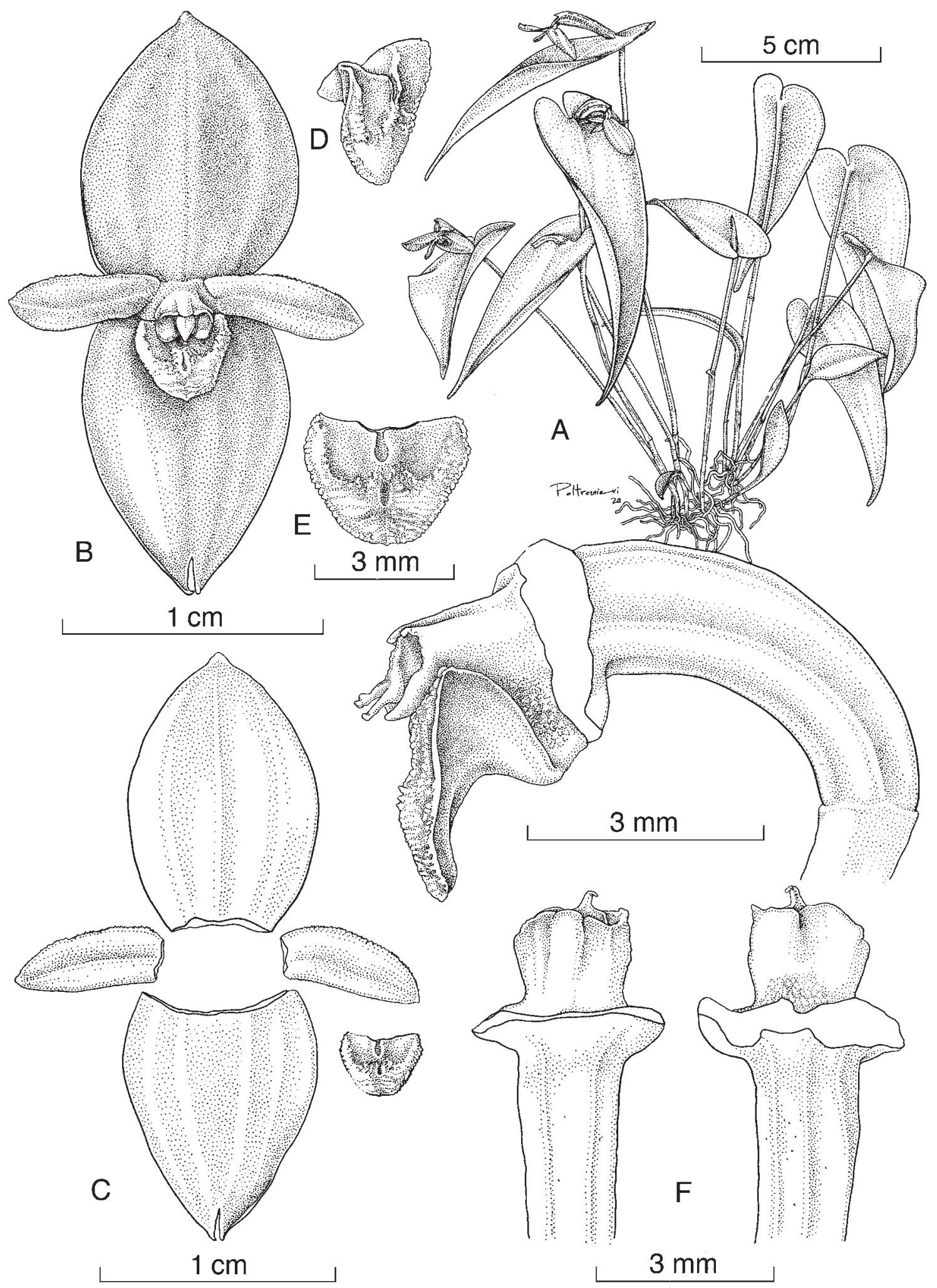

FIgURE 53. Pleurothallis triangulabia C. Schweinf. A, habit; B, flower; C, dissected perianth; D, lip, three quarters view; E, lip, adaxial view; F, ovary, column, and lip in lateral view; G, column in dorsal and ventral views. Drawn by S. Díaz Poltronieri from Pupulin 8739 (JBL). 


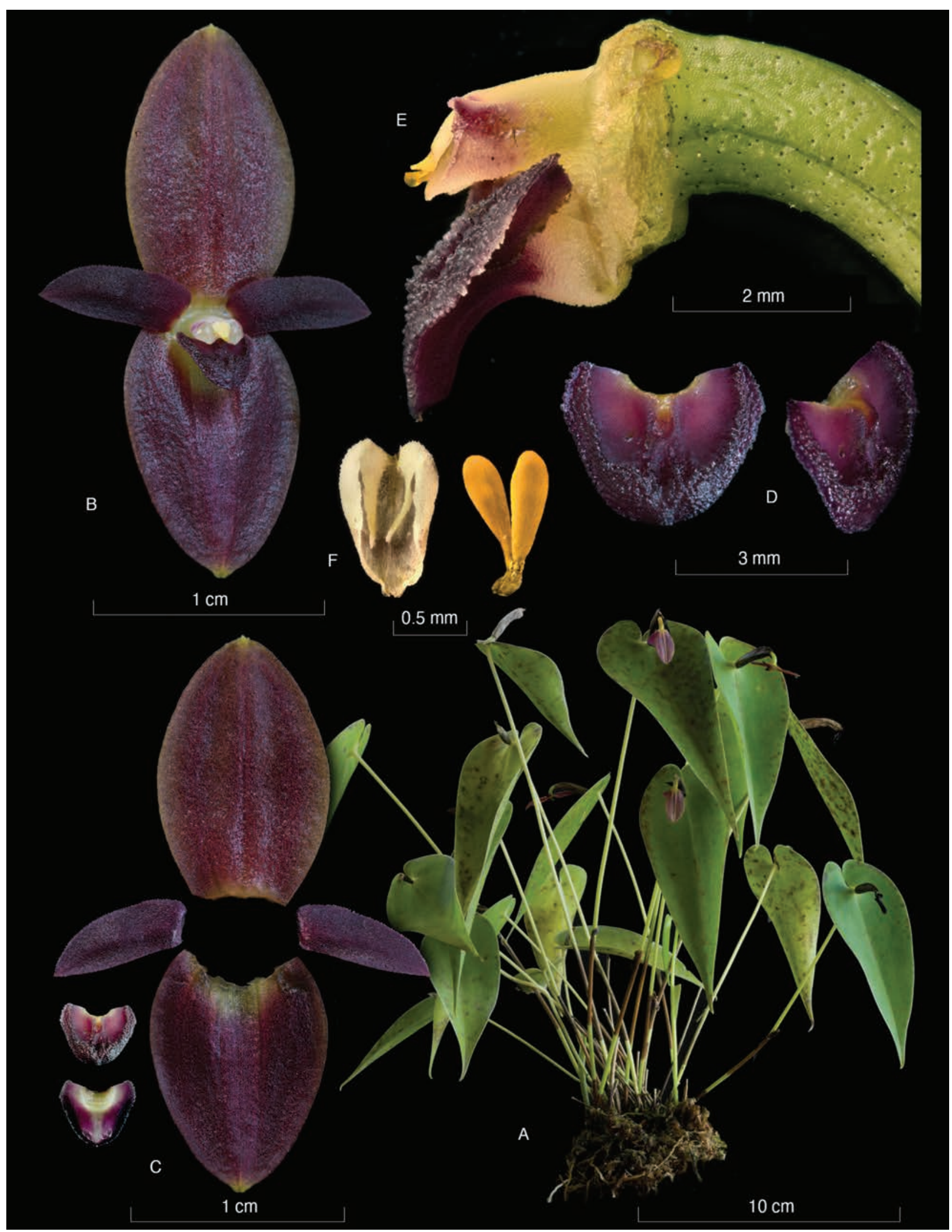

FIgURE 54. Pleurothallis triangulabia C. Schweinf. A, habit; B, flower; C, dissected perianth (lip in adaxial and abaxial views); D, lip, adaxial and three-quarter views; E, ovary, column, and lip in lateral view; $\mathbf{F}$, anther cap and pollinarium. Lankester Composite Dissection Plate prepared by F. Pupulin from Pupulin 8743 (JBL). 
Epiphytic, caespitose, erect herb to 19(27) cm tall. Roots slender, flexuous, ca. $1 \mathrm{~mm}$ in diam. Ramicauls terete, slender, 8-19(-27) cm long, 1-2 $\mathrm{mm}$ in diam., yellowish green, provided with a tubular, short, truncate sheath to 3 $\mathrm{cm}$ long at the base, and a longer, tubular, tightly adpressed, obtuse sheath below the middle, to $4.5 \mathrm{~cm}$ long, the bracts glumaceous, pale green when young, becoming brown, drypapyraceous with age. Leaf borne horizontally at the apex of the ramicaul, becoming subpendent with age, coriaceous, sessile, ovate, subacuminate, 5.6-10.0 × 3.0-5.9 cm, deeply cordate at the base with overlapping auricles, grass green, sometimes sparsely dotted with purple, matte. Inflorescence a solitary flower, from an erect spathaceous bract 1.7-3.0 $\mathrm{cm}$ long, green, dry-papyraceous when mature, eventually dissolving with age. Peduncle terete, slender, to $12 \mathrm{~mm}$ long. Pedicel terete, pale green, curving down throughout anthesis, 7-8 $\mathrm{mm}$ long. Ovary subclavate, terete, to $4 \mathrm{~mm}$ long. Flowers flushed with purple on a yellowish green background, often with darker purple stripes along the main veins, rarely solid dark purple. Dorsal sepal erect, elliptic to broadly ovate, obtuse to subacute, apiculate, flat, 12.0-12.5 × 8.0-9.8 mm, 3-veined. Lateral sepals connate into an ovate, acute synsepal, 10-12 ×8-9 mm, each half 2-veined. Petals elliptic-lanceolate, subfalcate, acute, spreading, the margins minutely denticulate, $6.5-7.3 \times 2.2-3.0 \mathrm{~mm}$, 3-veined. Lip unguiculate, hinged to the column foot, geniculate, transversely triangular, basally subcordate, obtuse, obscurely apiculate, 2.9-3.4 × 3.6-4.0 mm, verruculose on the adaxial surface of the apical half and along the margins, minutely papillose in front to the glenion; glenion on a cushion-like, convex callus recessed between the basal lobes of the lip, $0.7 \mathrm{~mm}$ long. Column short, transversely subrectangular, dorsiventrally complanate, apically obliquely truncate, ca. 2 $\times 1 \mathrm{~mm}$, the anther apical, bent, the stigma apical, bilobed. Anther cap ovate, truncate, bilobed at the base, 2-celled, $1.0 \times 0.6 \mathrm{~mm}$. Pollinia 2 , narrowly oblong-pyriform, $0.8 \times$ $0.3 \mathrm{~mm}$, attached to an elliptic viscidium through 2 short, cylindric caudiculae. Fig. 48H-I, 55.

Etymology: from the Latin triangulus, "triangle," and labium, "lip," in allusion to the shape of the labellum.

Distribution: Costa Rica and western Panama.

Ecology: populations of $P$. triangulabia were found growing epiphytically in secondary forests, as well as on scattered trees along pastures, in the premontane forest of the Cordillera Volcánica Central and Cordillera de Tilarán, at elevations of $1700-2400 \mathrm{~m}$. Due to their proximity to the watershed of the Continental Divide, the collecting localities of the species are constantly windy, with perennial intermittent rains and fogs that allow the establishment of a particularly rich epiphytic flora. The species flowers at least from February to November.

Distinguishing features: the relatively small plants, with stems mostly around 15-20 long, and the glabrous, flat flowers facing the leaf, with the dorsal sepal subequal in width to the synsepal, the petals elliptic-lanceolate, and the lip transversely rectangular, are diagnostic of the species.

Pleurothallis triangulabia is superficially similar to $P$. phyllocardia, with which it shares the shape of the ovate, acute leaves, deeply cordate at the base, the erect spathe, and the mostly dark purple flower that faces the surface of the leaf. Vegetatively, however, plants of P. triangulabia are usually distinctly smaller-a habit that the plants maintain also in cultivation - with mature stems around 15-20 cm long (vs. $30[-33] \mathrm{cm})$ and leaves to $10 \times 4 \mathrm{~cm}($ vs. $12 \times$ $7 \mathrm{~cm}$ ). The flowers are proportionately rounder, flat (vs. reflexed), often flushed with purple on a greenish yellow background (vs. solid purple in P. phylllocardia), with the dorsal sepal broadly ovate-suborbicular (vs. narrowly ovate), subequal to the synsepal (vs. distinctly wider), the petals shorter, elliptic-lanceolate (vs. oblong), and the transversely rectangular lip that is wider than long (vs. longer than wide).

Pleurothallis triangulabia has been traditionally treated as a synonym of $P$. phyllocardia (e.g., Pupulin, 2002; Luer, 2003; Bogarín et al., 2014; Kolanowska, 2014), which it superficially resembles, but the type specimen at AMES that we chose as the lectotype (Fig. 55) clearly shows the large synsepal, the elliptic-lanceolate and comparatively short petals, and the transversely rectangular lip that Schweinfurth described and illustrated on the type sheet (Fig. 56). Our recent collections from the western end of the Cordillera Volcánica Central and the Cordillera de Tilarán in Costa Rica correspond well to Schweinfurth's concept, and for this reason, we treat $P$. triangulabia here as a good species.

We have not seen the Panamanian syntype of Pleurothallis triangulabia from the Herbarium of the Missouri Botanical Garden, where the primary specimen is conserved according to the protologue (Schweinfurth, 1937). An isosyntype at NY shows a particularly large plant, likely over the upper dimensions that we have observed in P. triangulabia. Bogarín and co-workers (2014) treated the syntype collection (Seibert 269) from Chiriquí as conspecific with $P$. phyllocardia, a species that is effectively common in the same area, which is documented by several collections (e.g., Croat 26312, Croat \& Porter 16168, Allen 1468, Gentry 5882, Folsom 6024, Hammel 1425, Hammel et al. 7036, Liesner 315, and others, all at MO) and a photograph, which can be seen at RENZ (W. Löderbusch s.n., Slide no. 2040026, Swiss Orchid Foundation, 2016). The specimen that Schweinfurth (1937) designated as "cotype" might belong to a different taxon.

Costa Rican material examined: Alajuela: Alajuela: Alfaro Ruiz, Palmira, 2200 m, 9 Feb 1938, A. P. Smith H1167 (AMES). Same locality, 11 Jun 1938, A. P. Smith H1338 (AMES); 21 Sept 1938, A. P. Smith H1226 (AMES). Alfaro Ruiz, Palmira, 2400 m, 16 May 1938, A. P. Smith H592 (AMES). Same locality, 2000 m, 27 May 1938, A. P. Smith H667 (AMES); 2300 m, Jul 1938, A. P. Smith $H 932$ (AMES).Alfaro Ruiz, vecindad de Palmira, en bosque sobre colina, 1900 m, 13 Nov 1964, A. Jiménez M. 2560 (AMES). Carrizal, Concordia, entre Los Cartagos y Cinco Esquinas, bosque pluvial montano bajo, en potreros arbolados y bosque secundario, $10^{\circ} 08^{\prime} 16.8^{\prime \prime} \mathrm{N}, 84^{\circ} 09^{\prime} 49.8^{\prime \prime} \mathrm{W}, 2027 \mathrm{~m}$, 17 Junio 2009, en cultivo en el Jardín Botánico Lankester, May 2011, D. Bogarín 7308, R. L. Dressler, F. Pupulin \& R. Trejos (JBL); same locality and data, D. Bogarín 7456, R. L. Dressler, F. Pupulin \& R. Trejos (JBL). Quesada, arbres des 


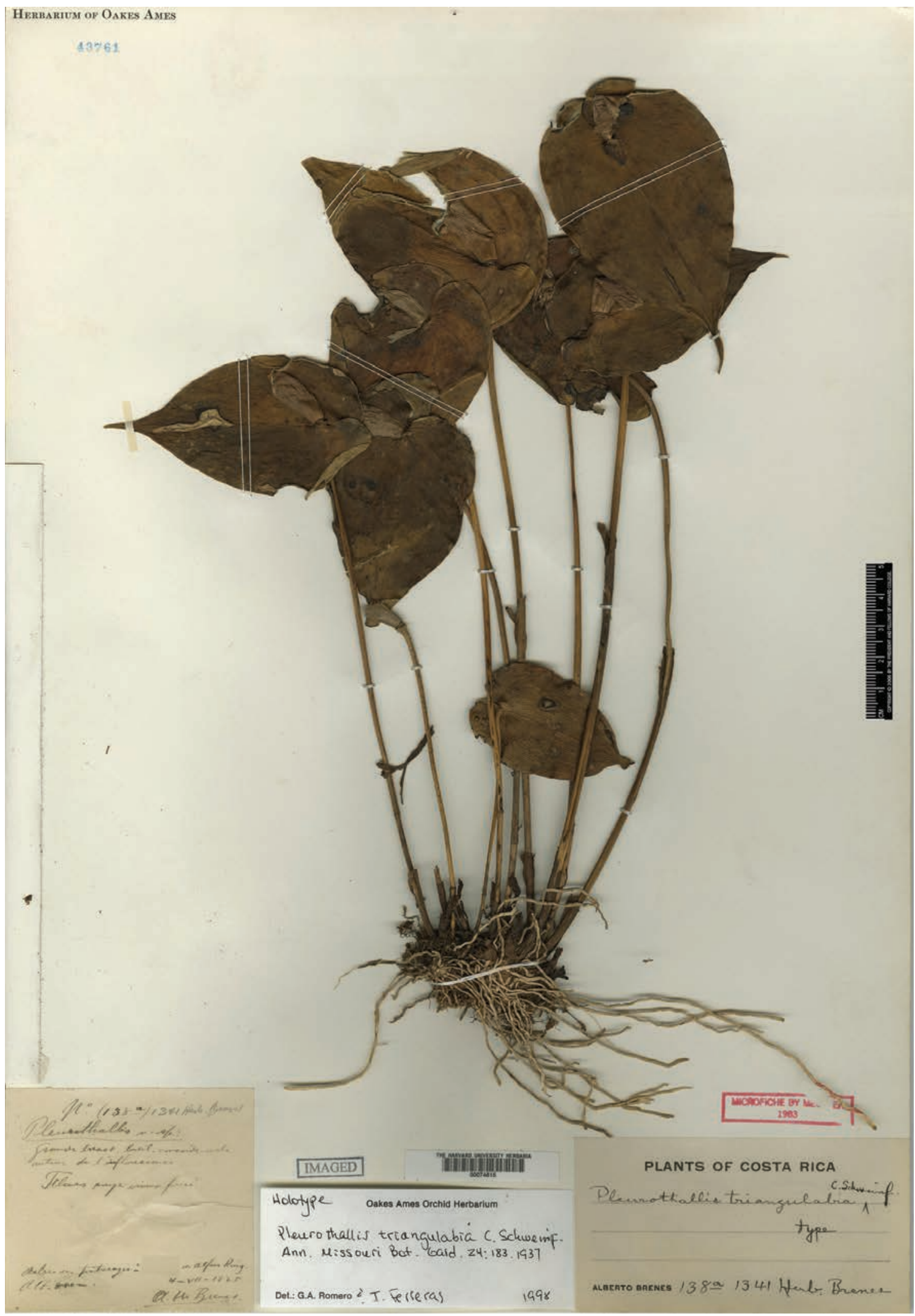

FIGURE 55. Lectotype of Pleurothallis triangulabia, a specimen collected in Costa Rica by A. M. Brenes (138a) 1341 (AMES 43761). Reproduced with kind permission from the Keeper, Oakes Ames Orchid Herbarium, Harvard University Herbaria. 


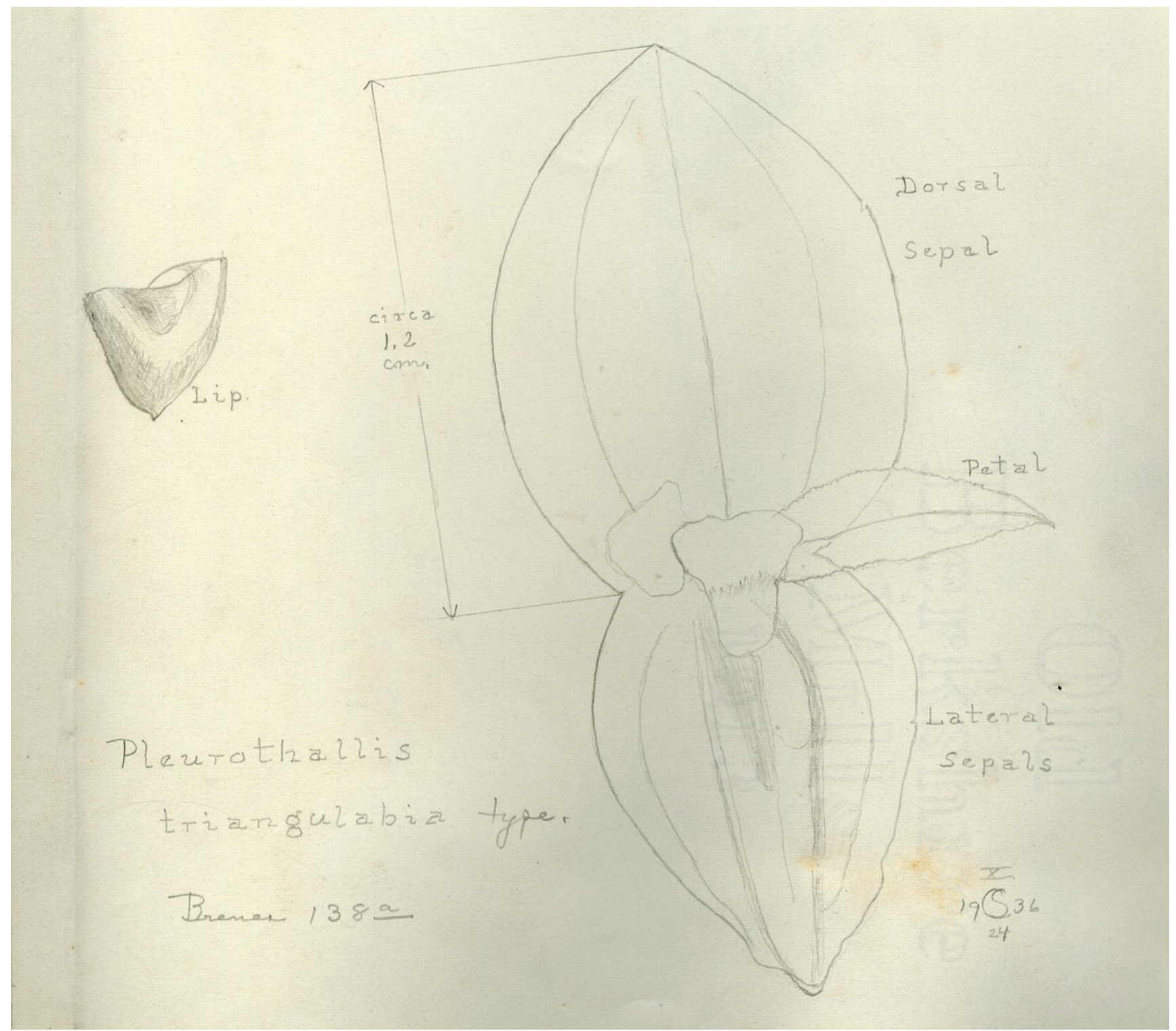

FIGURE 56. Charles Schweinfurth's sketch of the flower from the lectotype of Pleurothallis triangulabia, mounted on the type sheet (AMES 43761). Reproduced with kind permission from the Keeper, Oakes Ames Orchid Herbarium, Harvard University Herbaria.

paturages a Palmira de Alfaro Ruiz, [ca. $\left.10^{\circ} 13^{\prime} \mathrm{N}, 84^{\circ} 23^{\prime} \mathrm{W}\right]$, 840 m, 4 Jul 1925A. M. Brenes (138a) 1341 (AMES). San Ramón, Angeles, Monteverde, road to TV Tower, Z.P. Arenal-Monteverde Caribe, 10.2944444, -84.7500003, 1700 m, 24 Aug 1985, W. Haber 2360 (CR). Guanacaste: Abangares, Sierra, R.B. Monteverde. Cerro Dos Amigos in area TV towers, cloud forest, 10.3333333, -84.8333333, 10 Oct 1985, W. Haber 3466 \& E. Bello (CR). Heredia: Vara Blanca, 7 Feb 1936, R. Valerio R. 361 (AMES). Puntarenas: Puntarenas, Monteverde, main road toward the summit of Cerro Amigos, $10^{\circ} 19^{\prime} 08.6^{\prime \prime} \mathrm{N}, 84^{\circ} 48^{\prime} 01.0^{\prime \prime} \mathrm{W}, 1750 \mathrm{~m}$, wet lower montane forest, epiphytic in secondary vegetation, 6 March 2015, F. Pupulin 8743, D. Bogarín, M. Díaz \& M. Fernández (JBL). Puntarenas, Monteverde, sendero hacia la cumbre del Cerro Amigos entrando por la estación del CIEE, $10^{\circ} 19^{\prime} 20^{\prime \prime} \mathrm{N}, 84^{\circ} 48^{\prime} 27^{\prime \prime} \mathrm{W}, 1600 \mathrm{~m}$, bosque nuboso, epífitas en bosque secundario maduro, 11 junio 2016, floreció en cultivo en el Jardín Botánico Lankester, 3 Aug 2016, M. Diaz 247, M. Fernández \& L. Oses (JBL). Puntarenas, Monteverde, sendero hacia la cumbre del Cerro Amigos, $10^{\circ} 19^{\prime} 17.00^{\prime \prime} \mathrm{N}, 84^{\circ} 47^{\prime} 55.30^{\prime \prime} \mathrm{W}, 1722 \mathrm{~m}$, bosque pluvial montano bajo, epífitas en bosque secundario, 5 Marzo 2015, floreció en cultivo en el Jardín Botánico Lankester, 12 Jul 2016, M.Fernández 1019, D. Bogarín, M. Díaz, F. Pupulin \& A. Salazar (JBL). Puntarenas: Puntarenas, Monteverde, main road toward the summit of Cerro Amigos, $10^{\circ} 19^{\prime} 08.6^{\prime \prime} \mathrm{N}, 84^{\circ} 48^{\prime} 01.0^{\prime \prime} \mathrm{W}, 1750 \mathrm{~m}$, wet lower montane forest, epiphytic in secondary vegetation, 6 March 2015, flowered in cultivation at Jardín Botánico Lankester, 12 Jul 2016, F. Pupulin 8735, D. Bogarín, M. Díaz \& M. Fernández (JBL). Same locality data, flowered in cultivation at Jardín Botánico Lankester, 1 Jul 2020, F. Pupulin 8758, D. Bogarín, M. Díaz \& M. Fernández (JBL). Map 4. 


\section{EXCLUDED SPECIES}

Pleurothallis scitula Luer, Selbyana 3(3-4): 384. 1977.

TYPE: Panama. Chiriquí: epiphytic in cloud forest on Cerro Hornito, alt. ca. 1700 m, 15 Dec 1976, C. Luer 1361, A. Luer, R. L. Dressler, N. H. Williams \& F. L. Stevenson (Holotype: SEL).

Pupulin (2002) cited a voucher for Pleurothallis scitula from the rain montane forest of cerro Chomogo in the Cordillera de Tilarán (Boyle 75-89, USJ), but a recent reexamination of that collection revealed that it belongs instead to $P$. triangulabia, a species occurring relatively frequently around Monteverde. Boyle 75-89 has narrowly ovate leves (vs. broadly ovate in P. scitula), concolorous purple flowers (vs. yellow striped with red) facing the leaf (vs. erect), with the synsepal smaller than the dorsal sepal (vs. larger), and relatively short, elliptic petals (vs. narrowly lanceolate). Another Costa Rican voucher was cited by Grayum et al. (2008), based on a specimen collected in 2005 from the Pacific slope of the Cordillera de Talamanca near the Panamanian border, and flowered in cultivation in 2007 (J. F. Morales 15793, then at INB, later at CR). With the help of CR curator Silvia Lobo, we searched for this specimen that is included in the National Museum database, but unfruitfully, as among the collection of CR the folder of $P$. scitula is missing. Without having been able to observe a sure voucher of this species in Costa Rica, we are not in a position to provide a description and illustration of $P$. scitula for this article, and we have no other option for the moment but to exclude it from treatment.

\section{Literature Cited}

Aguiar, C. M. L., G. M. M. Santos, C. F. Martins, and S. J. PRESLEY. 2013. Trophic niche breadth and niche overlap in a guild of flower-visiting bees in a Brazilian dry forest. Apidologie 44: $153-162$.

AmEs, O. 1922. Descriptions of new Orchids from tropical America with nomenclatorial changes. Proc. Biol. Soc. Wash. 35: 81-87.

-_-_--. 1936. A new Pleurothallis from Costa Rica. Bot. Mus. Leafl. 4: 41-46.

AmEs, O., AND C. SchweINFURTH. 1925. New or noteworthy species of orchids from the American tropics. Schedulae Orchidianae 8: 1-91.

Bogarín, D., A. P. Karremans, and M. Muñoz García. 2015. Brachionidium kirbyi, eine neue Art zu Ehren des Gründers des Orchideenprojektes "Bosque de Paz" in Costa Rica / Brachionidium kirbyi, a new species honoring the founder of the "Bosque de Paz" Orchid Project in Costa Rica. Die Orchidee 66(5): 404-409.

Bogarín, D., O. A. Pérez-Escobar, D. Groenenberg, S. D. Holland, A.P. Karremans, E. Moriarty Lemmon, A. R. Lemmon, F. Pupulin, E. SMets, and B. GravendeEl. 2018. Anchored hybrid enrichment generated nuclear, plastid and mitochondrial markers resolve the Lepanthes horrida (Orchidaceae: Pleurothallidinae) species complex. Mol. Phylogenet. Evol. 129: 27-47.

Bogarín, D., Z. Serracín HernándeZ, Z. SAmudio, R. Rincón, and F. Pupulin. 2014. An updated checklist of the Orchidaceae of Panama. Lankesteriana 14(3): 135-364.

Díaz-Morales, M., and A. P. Karremans. 2015. Pollination biology of five species of Pleurothallidinae in a montane region in Costa Rica. Poster presented at the V Scientific Conference on Andean Orchids, Cali, Colombia, 2015.

DI VITA, A. 2017. Hortus Orchis. Lepanthes escobariana. Retrieved from http://www.hortusorchis.org/en/botanical-orchids/117-1/ 1430-lepanthes-escobariana.html. (consulted September 2020).

Dodson, C. H. 2004. Ecuador orchid list. Pages 1112-1156 in C. H. Dodson, Native Ecuadorian Orchids, 5. RodrigueziaZygosepalum. Imprenta Mariscal, Quito, Ecuador.

Doucette, A., M. Wilson, J. Portilla, A. Kay, J. S. Moreno, and K. M. Cameron. 2016. Dos especies nuevas de Pleurothallis y un nuevo nombre para Acronia rinkei. Orquideología XXXIII: $123-135$.

Duque-Buitrago, C. A., N. F. Alzate-Quintero, and J. T. Otero. 2014. Nocturnal pollination by fungus gnats of the Colombian endemic species, Pleurothallis marthae (Orchidaceae: Pleurothallidinae). Lankesteriana 13: 407-417.
Duque Hernández, Ó. 2008. Orchidaceae Stelis Swartz Compendium. Editorial Universidad de Antioquia, Colombia.

Grayum, M. H., B. E. Hammel, and N. Zamora. 2008. Leaps and Bounds. Orchidaceae. The Cutting Edge 15(1). Retrieved from http://www.mobot.org/MOBOT/research/Edge/jan08/jan08lea. shtml. (accessed August 2020).

INTERNICOLA, A. I., AND L. D. HARDER. 2012. Bumble-bee learning selects for both early and long flowering in food-deceptive plants. Proc. Royal Soc. B 279(1733): 1538-1543.

Karremans, A. P. 2016. Genera Pleurothallidinarum: An updated phylogenetic overview of Pleurothallidinae. Lankesteriana16(2): 219-241.

-_-_-_. 2019. To be or not to be a Stelis. Lankesteriana 19(3): 281-343.

Karremans, A. P., And D. Bogarín. 2011. Pleurothallis adventurae (Orchidaceae: Pleurothallidinae), eine neue Art aus einer unerforschten Region in Costa Rica / Pleurothallis adventurae (Orchidaceae: Pleurothallidinae), una nueva especie de una región inexplorada en Costa Rica. Orchideen Journal 18(3): 111-114.

Karremans, A. P., and M. Díaz-Morales. 2019. The Pleurothallidinae: Extremely high speciation driven by pollinator adaptation. Pages 363-388 in A. M. Pridgeon AND A. R. Arosemena, EDS., Proceedings of the 22nd World Orchid Conference. Vol. 1. Asociación Ecuatoriana de Orquideología, Guayaquil, Ecuador.

Karremans, A. P., and M. Muñoz García. 2011. Pleurothallis silvae-pacis, a new species. Orchid Rev. 119(1295): 155-159.

KIRBY, S. 2003. Neotropical orchid eco-tourism: Educational experience of an orchid neophyte at the Bosque de Paz Biological Preserve, Central Volcanic Range, Costa Rica. Lankesteriana 7: 121-124.

KIRBY, S., AND M. MuÑoz. 2007. A form and checklist for the description of orchids in the field and laboratory work. Lankesteriana 7(1-2): 175-177.

Kolanowska, M. 2014. Orchids of Darién Gap. Koeltz Scientific Books, Koenigstein, Germany.

Kuntze, O. 1891. Humboltia cardiothallis (Rchb.f.) Kuntze. Revisio Generum Plantarum 2: 667.

LiNDLEY, J. 1859. Folia Orchidacea. An enumeration of the known species of orchids. Pleurothallis 9-12. Published for the author by J. Matthews, London.

LUER, C. A. 1976. Icones Pleurothallidinarum: Miscellaneous species of Pleurothallis. Selbyana, 3(1-2): 38-201. 
1977. Icones Pleurothallidinarum, miscellaneous species in the Pleurothallidinae. Selbyana 3(4): 204-407.

-_-_-_. 1979. Icones Pleurothallidinarum, miscellaneous new species in the Pleurothallidinae. Selbyana 5: 145-196.

--_-- 1985. A key to the genera of the Pleurothallidinae. Pages 239-245 in K. W. TAN, ED., Proceedings of the Eleventh World Orchid Conference. Miami, Florida.

--_---. 1986. Icones Pleurothallidinarum III: Systematics of Pleurothallis. Monogr. Syst. Bot. Missouri Bot. Gard. 20: 1-109

--_-_- 1988. A revision of some sections of subgenus Pleurothallis. Lindleyana 3(3): 133-149.

1996. New species in the Pleurothallidinae from Costa

Rica. Lindleyana 11: 54-113.

--_--_. 1997. New species of Lepanthes and Pleurothallis from Guatemala, Panama, Peru, Suriname, and Venezuela. Lindleyana 12: $34-55$.

--_---. 2002. Icones Pleurothallidinarum XXIV. A first century of new species of Stelis of Ecuador. Part 1. Addenda to the Lepanthes of Ecuador. Addenda to Barbosella, Dracula, Dresslerella, Lepanthopsis, Platystele, Pleurothallis, Restrepia, Scaphosepalum, Teagueia and Trichosalpinx. Monogr. Syst. Bot. Missouri Bot. Gard. 88.

------. 2003. Pleurothallis. In B. E. Hammel, M. H. Grayum, C. Herrera, and N. Zamora, eds., Manual de Plantas de Costa Rica. Vol. 3. Monogr. Syst. Bot. Missouri Bot. Gard. 93.

. 2004. Icones Pleurothallidinarum XXVI. Pleurothallis subgenus Acianthera and three allied subgenera. A second century of new species of Stelis of Ecuador. Epibator, Ophidion, Zootrophion. Monogr. Syst. Bot. Missouri Bot. Gard. 95.

. 2005. Icones Pleurothallidinarum XXVII. Dryadella and Acronia sect. Macrophyllae-Fasciculatae. Monogr. Syst. Bot. Missouri Bot. Gard. 103: 1-311.

--_---. 2007. Icones Pleurothallidinarum XXIX. A third century of Stelis of Ecuador: systematics of Apoda-prorepentia: systematics of miscellaneous small genera: addenda, new genera, species, and combinations (Orchidaceae). Monogr. Syst. Bot. Missouri Bot. Gard. 112.

2009. Systematic of Stelis. Stelis of Ecuador. Part 4. Monogr. Syst. Bot. Missouri Bot. Gard. 115: 31-237.

Mansfeld, R. 1931. Blütenanalysen neuer Orchideen von R. Schlechter. II. Mittelamerikanische Orchideen. Repert. Spec. Nov. Regni Veg. Beih. 59: Tab. 1-81.

Mo, E. A., And W. Cetzal-Ix. 2015. Pleurothallis cardiothallis (Pleurothallidinae): An orchid with contraceptive properties used by indigenous q'eqchi in Cobán, Alta Verapaz, Guatemala. Mosaic (Southern Alberta Ethnic Association) 3(2): 15-16.

Monro, A. K., D. Santamaría-Aguilar, F. González Brenes, O. Chacón, D. Solano, A. Rodríguez González, N. Zamora Villalobos, E. Fedele, and M. D. Correa A. 2017. A first checklist to the vascular plants of La Amistad International Park (PILA), Costa Rica-Panama. Phytotaxa 322(1): 1-283.

MuÑoz, M., AND S. H. KIRBY. 2007. An orchid inventory and conservation project at Bosque de Paz Biological Reserve, upper Río Toro Valley, Alajuela, Costa Rica. Lankesteriana 7 (1-2): 60-65.

Papadopulos, A. S. T., M. P. Powell, F. Pupulin, J. Warner, J. A. Hawkins, N. Salamin, L. Chittka, N. H. Williams, W. M. Whitten, D. Loader, L. M. Valente, M. W. Chase, and V. Savolainen. 2013. Convergent evolution of floral signals underlies the success of Neotropical orchids. Proc. Royal Soc. B. 280: 20130960 .
Pérez-Escobar, O., G.Chomicki, F.L.Condamine,A.P. Karremans, D. Bogarín, N. J. Matzke, D. Silvestro, and A. Antonelli. 2017. Recent origin and rapid speciation of Neotropical orchids in the world's richest plant biodiversity hotspot. New Phytol. 215: 891-905.

Presl, C. B. 1827. Reliquiae Haenkeanae, seu Descriptiones et icones plantarum, quas in America Meridionali et Boreali, in insulis Philippinis et Marianis collegit Thaddaeus Haenke. Fasc. 2, pp. 85-148. Apud J.G. Calve, Pragae.

Pridgeon, A. M. 2005. Pleurothallis. Pages 385-390 in A. M. Pridgeon, P. Cribb, M. W. Chase, and F. N. Rasmussen, eds., Genera Orchidacearum. Vol. 4: Epidendroideae (Part 1). Oxford University Press, Oxford.

--_---. 2020. Pleurothallis. Pages 850-909 in F. Pupulin, ED., Vanishing Beauty. Native Costa Rican Orchids. Vol. 2: LacaenaPterichis. Koeltz Botanical Books, Oberreifenberg.

Pridgeon, A. M., ANd M. W. Chase. 2001. A phylogenetic reclassification of the Pleurothallidinae (Orchidaceae). Lindleyana 16: 2365-2371.

Pridgeon, A. M., R. Solano, And M. W. Chase. 2001. Phylogenetic relationships in subtribe Pleurothallidinae (Orchidaceae): Combined evidence from nuclear and plastid DNA sequences. Amer. J. Bot. 88: 2286-2308.

Pupulin, F. 2002. Catálogo revisado y actualizado de las Orchidaceae de Costa Rica. Lankesteriana 4: 1-88.

--_---. 2003. A second look at the genus Sigmatostalix (Orchidaceae: Oncidiinae) in Costa Rica. Harvard Pap. Bot. 8(1): 35-59.

--_---, ED. 2020. Vanishing Beauty. Native Costa Rican Orchids. Vol. 2: Lacaena-Pterichis. Koeltz Botanical Books, Oberreifenberg.

Pupulin, F., N. Belfort-Oconitrillo, A. P. Karremans, and D. Bogarín. 2020. Florae costaricensis subtribui Pleurothallidinis prodromus. 1. Systematics of Echinosepala (Orchidaceae). Harvard Pap. Bot. 25(2): 155-190.

Pupulin, F., D. Bogarín, M. Fernández, M. Díaz-Morales, and C. Ossenbach. 2016. Orchidaceae Tonduzianae: Typifications of Costa Rican Orchidaceae described from collections of Adolphe Tonduz. Harvard Pap. Bot. 21(2): 263-320.

Pupulin, F., M. Díaz-Morales, J. Aguilar, and M. Fernández. 2017. Two new species of Pleurothallis (Orchidaceae: Pleurothallidinae) allied to $P$. cardiothallis, with a note on flower activity. Lankesteriana 17(2): 329-356.

Pupulin, F., M. Díaz-Morales, M. Fernández, and J. Aguilar. 2017. Two new species of Pleurothallis (Orchidaceae: Pleurothallidinae) from Costa Rica in the P. phyllocardia group. Lankesteriana 17(2): 153-164.

Pupulin, F., And G. A. Rojas. 2006. A new species of Sigmatostalix (Orchidaceae: Oncidiinae) from Costa Rica, and its concolorous form. Orchids (Amer. Orch. Soc. Bull.) 75(9): 677-683.

Reichenbach, H. G. 1857. Gartenorchideen, VI. Botanische Zeitung (Berlin) 15: 157-159.

1866. Beiträge zu einer Orchideenkunde CentralAmerika's. Druck von T. G. Meissner, Hamburg.

Ruzz, H., AND J. PAvón. 1798. Systema vegetabilium Florae Peruvianae et Chilensis, characteres prodromi genericos differentiales, specierum omnium differentias, durationem, loca natalia, tempus florendi, nomina vernacula, vires et usus nonnullis illustrationibus interspersis complectens. Typis Gabrielis de Sancha, Madrid. 
Santos, G. M. M., And S. J. Presley. 2010. Niche overlap and temporal activity patterns of social wasps in a Brazilian cashew orchard. Sociobiology 56: 121-131.

SCHLECHTER, R. 1918. Kritische Aufzaehlung der bisher aus ZentralAmerika bekanntgewordenen Orchideen; D. Beschreibungen neuer Arten. Beihefte zum Botanischen Centralblatt 36: 371421.

SchweInfurth, C. 1937.Contributions toward a Flora of Panama. I. Collections in the Provinces of Chiriquí, Coclé, and Panamá, by R. J. Seibert during the summer of 1935. Ann. Missouri Bot. Gard. 24: 175-210.

Swiss Orchid Foundation. 2016. Pleurothallis phyllocardia, Slide 2040026. Retrieved from https://orchid.unibas.ch/index. php/en/?option=com_content $\&$ view $=$ article $\&$ id $=3 \&$ Search ResultID=2040026/Pleurothallis/phyllocardia/Reichenbach_ Heinrich_Gustav\&setLang=en-GB. (accessed August 2020).

SzlachetKo, D. L., AND B. H. Margonska. 2001. Genera et species orchidalium. Polish Bot. J. 46(2): 113-121.
Wilson, M., C. Belle, A. Dang, P. Hannan, L. Kellogg, C. Kenyon, H. Low, A. Mochizuki, A. Nguyen, N. Sheade, L. Shan, A. Shum, T. Stayton, C. Volz, B. Vosburgh, H. Wellman, AND M. A. Woolley. 2013. Preliminary phylogenetic analysis of Pleurothallis sensu lato based upon nuclear and plastid sequences. Abstract of poster presented at 4th Scientific Conference on Andean Orchids, November 2012, Guayaquil, Ecuador. Lankesteriana 13(1-2): 139.

Wilson, M., C. Belle, A. Dang, P. Hannan, C. Kenyon, H. Low, T. Stayton, And M. Woolley. 2011. A phylogenetic analysis of the genus Pleurothallis, with emphasis on Pleurothallis subsection Macrophyllae-Fasciculatae, using nuclear ITS and chloroplast DNA sequencing. Lankesteriana 11(3): 369.

Wilson, M., F. Pupulin, F. I. Archila-Morales, A. Damon, and R. SolANo-Gómez. 2013. A newly recognized clade of Pleurothallis with Mesoamerican distribution. Proceedings of the 4th Scientific Conference on Andean Orchids, Guayaquil, Ecuador, 2012. Lankesteriana 13(1-2): 138. 
Page 296 intentionally left blank.

Downloaded From: https://bioone.org/journals/Harvard-Papers-in-Botany on 12 Oct 2021 Terms of Use: https://bioone.org/terms-of-use Access provided by Max Planck Digital Library 